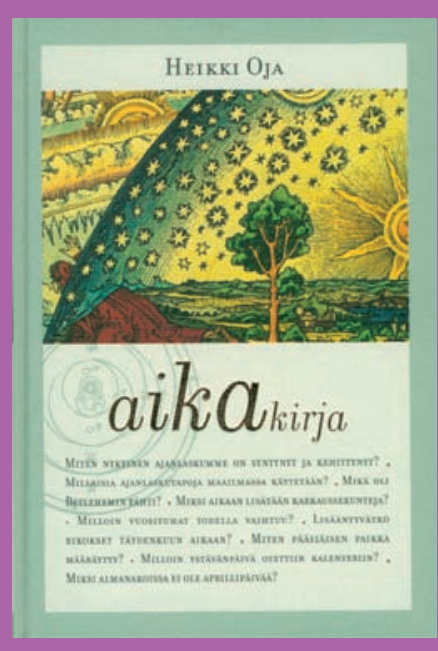

Alkuperäinen Aikakirja ilmestyi Otavan kustantamana 1999.

Aikakirja 2007 ilmestyi verkossa vuonna 2007 ja Aikakirja 2010 vuonna 2010.

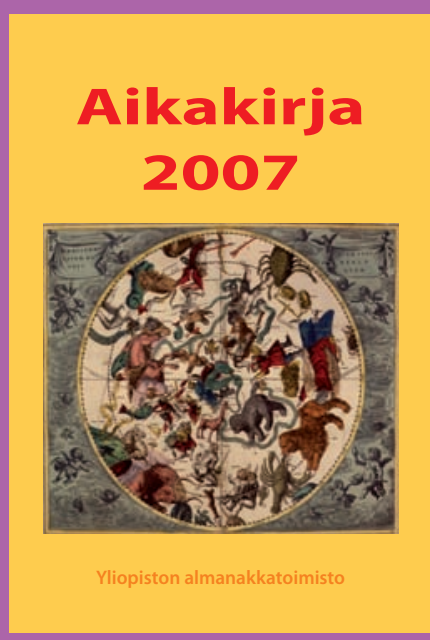

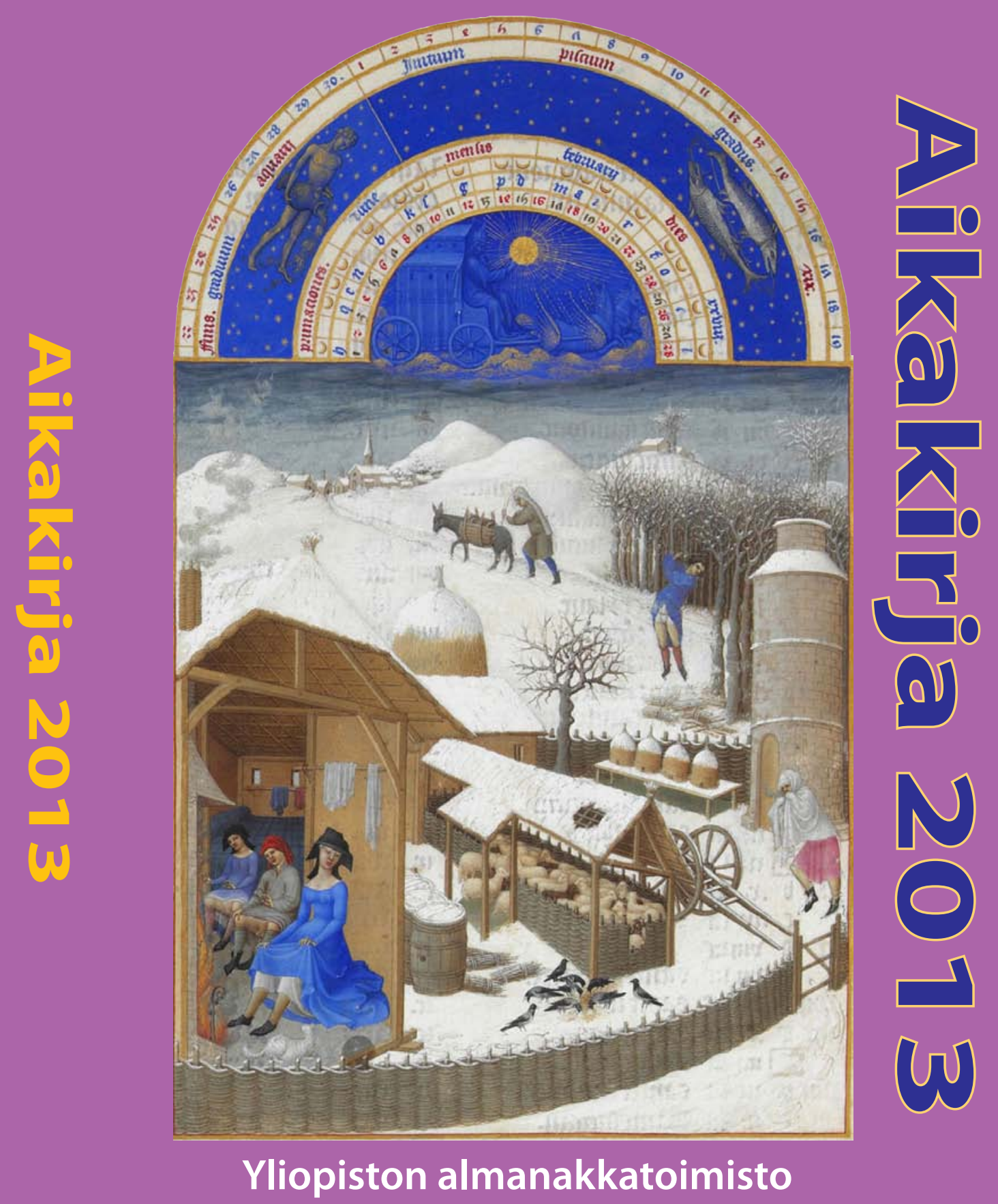

0
0
0
0
0
0
0
0
0
0

\title{
Aikakirja 2013
}

Kannessa helmikuun kuva kirjasta Les Trés Riches Heures du Duc de Berry vuodelta 1412-16 (Wikimedia Commons) 
AIKAKIRJA

2013 


\section{AIKAKIRJA 2013}

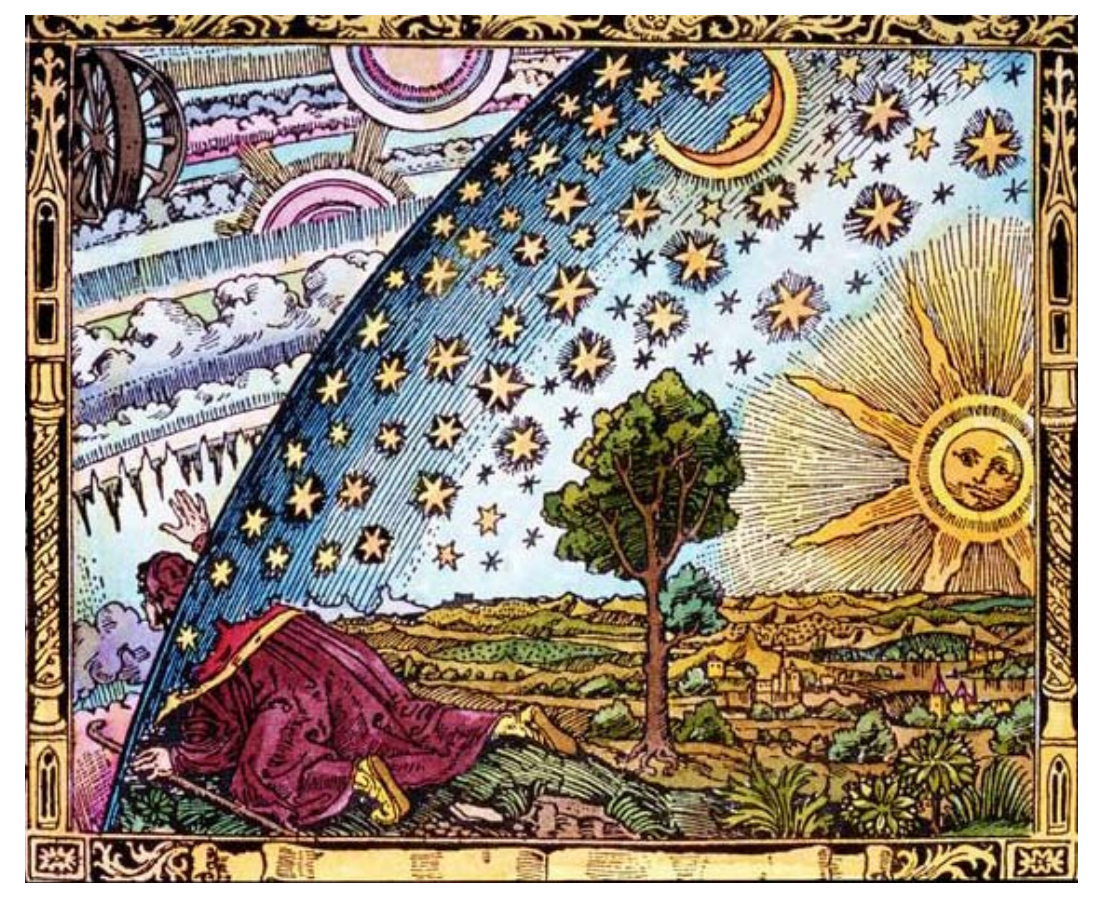

Keskiaikaiseeen tyyliin tehty puupiirros, joka kuvaa tähtitieteilijää tunkeutumassa pallonkuorten läpi. Piirros on luultavasti 1800-luvulla eläneen Camille Flammarionin käsialaa.

\section{Heikki Oja}

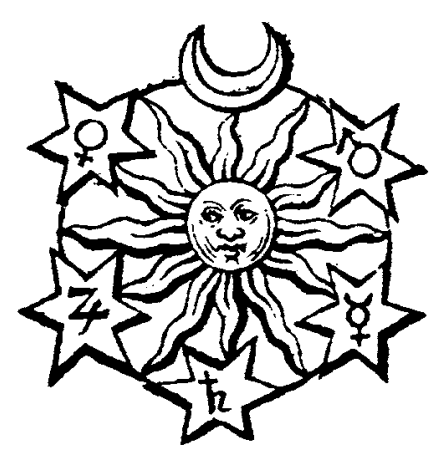

Helsinki 2013

Helsingin

yliopiston almanakkatoimisto 


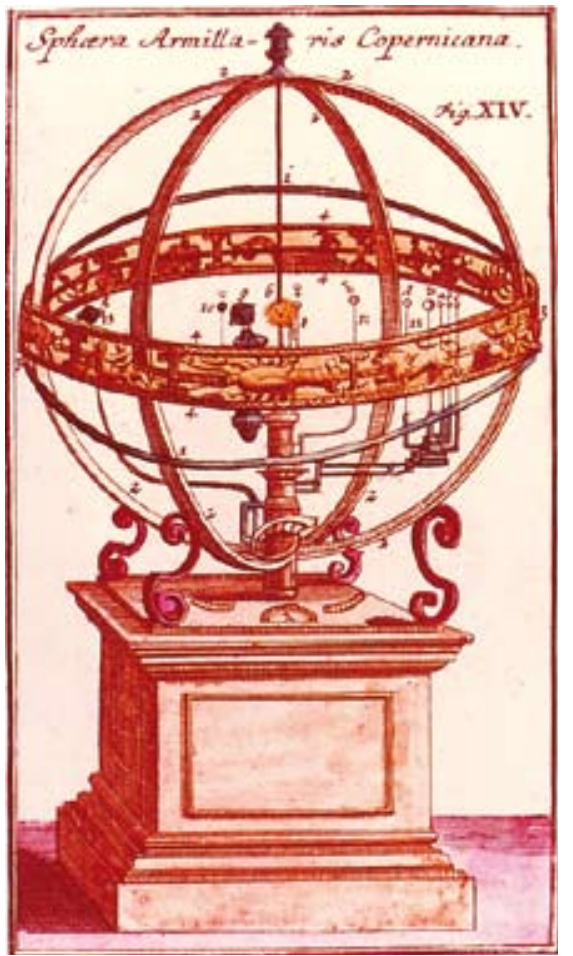

Väritetty kuparipiirros vuodelta 1769. Piirros esittää mekaanista planetaariota, joka kuvaa Kopernikuksen aurinkokeskistä maailmanmallia.

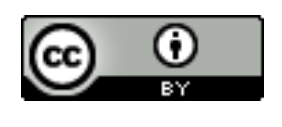

Teoksen tekstit, viivapiirrokset sekä Heikki Ojan ja Arja Latvala-Ojan kuvat on

lisensoitu avoimella CC BY 4.0 -lisenssillä. M uiden kuvien lähteet ja

tekijänoikeustiedot kts. sivulta 267. Tämän teoksen on julkaissut Helsingin yliopiston kirjasto HY:n Almanakkatoimiston luvalla.

DOI: $10.31885 / 9521032219$

Lähdeviittaukset kirjan sisäosan kuviin sivulla 267.

(c) Heikki Oja ja Helsingin Yliopiston Kehityspalvelut Oy,

Yliopiston almanakkatoimisto

Taitto ja typografia Arja Latvala-Oja

6. painos, verkkoversio, huhtikuu 2013

ISBN 951-1-16334-5 (alkuperäinen kirja, 1.-3. painos, kustantajana Otava)

ISBN 952-10-3221-9 (4.-6. painos, PDF).

\section{Sisältö}

Lukijalle ............................................. 7

1. 50 kysymystä ajasta ja kalenterista

.11

Tavallisimmat yleisökysymykset Betlehemin tähdestä

vuosituhannen vaihtumiseen

2. Ajanlaskun aakkosia.

Ajanlaskun ja kalenterien kehitys Babyloniasta nyky-

päivään ja kalentereita eri puolilta maailmaa

3. Ajanmittaus

Ajanmittauksen ja kellojen kehitys taivaan kelloista uusimpiin atomikelloihin

4. Luonnon merkkipäiviä vuoden varrella

Vuodenaikojen vaihtelu ja tähtitaivaan tapahtumat

pimennyksistä tähtisateisiin

5. Kirkkovuoden juhlat

Kirkon juhlapäivät adventista tuomiosunnuntaihin vanhoissa ja uusissa kalentereissa

6. Kansalliset ja kansainväliset merkkipäivät .... 179

Kansallisia ja kansainvälisiä yhteiskunnallisia juhlapäiviä ja nimipäiväkalenterimme kehittyminen

7. Suomalaisen almanakan kehitys

Suomen almanakkojen kehitys vuoden 1608

Forsiuksen almanakasta nykyaikaan

\section{Liite}

Tärkeimpiä vuosilukuja ajanlaskun ja kalenterien

kehityksessä

Lähdeteoksia ja kuvalähteitä

Hakemisto 


\section{LUKIJALLE}

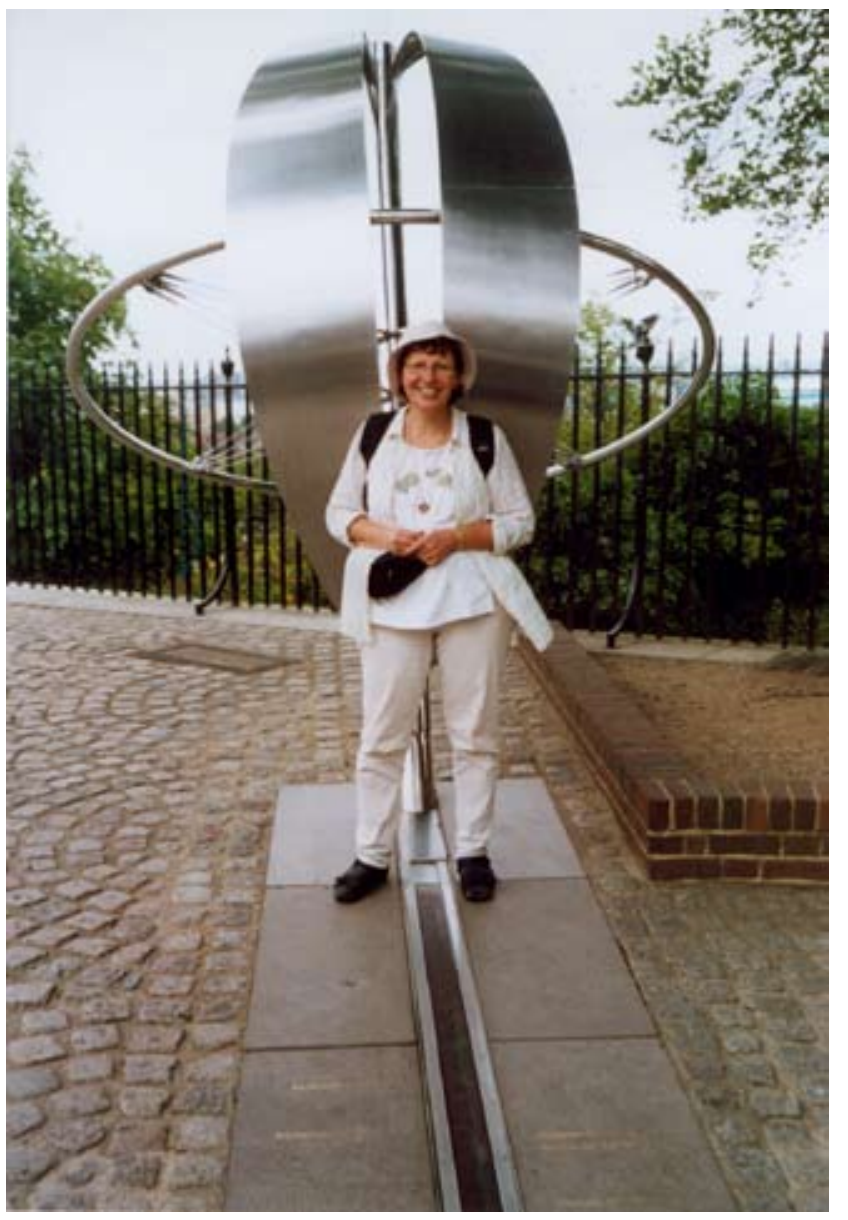

Greenwichin observatorion pihalle Lontooseen on merkitty messinkilistalla maapallon nollameridiaani. Kävijä voi seistä pihalla toinen jalka itäisellä ja toinen läntisellä pallonpuoliskolla. ika on poikkeuksellinen luonnonilmiö. Se on läsnä kaikkialla, mutta siihen ei saa kunnolla otetta. Olemme kaikki ajan vankeja emmekä voi millään tavalla vaikuttaa sen kulkuun. Se etenee omaa majesteettista tahtiaan muusta luomakunnasta välittämättä.

Ajan olemusta on pohdittu jo tuhansia vuosia. Asialla ovat olleet niin teologit, filosofit kuin luonnontieteilijätkin.

Tässä kirjassa emme ryhdy pohtimaan kysymystä, mitä aika on. Hyväksymme sen oleelliseksi osaksi maailmankaikkeutta, yhtä perustavaksi asiaksi kuin itse avaruuden. Keskitymme pohtimaan sitä, miten aikaa on ruvettu mittaamaan tälllä maapallollamme ja millaisia ajanlaskutapoja erilaisissa kulttuureissa on muodostunut.

Ihminen on vuosituhansien varrella kehittänyt keinot niin pitkien kuin lyhyidenkin ajanjaksojen mittaamista varten. Tavallisimpia aikamittoja suurimmasta pienimpään ovat

- vuosi, vuodenaikojen toistumisjakso esimerkiksi vuoden lyhimmästä päivästä seuraavan vuoden lyhimpään päivään.

- kuukausi, joka alun perin merkitsi aikaa uuden kuunsirpin ilmestymisestä seuraavaan uuteen kuuhun.

- viikko, seitsemän päivää. Luku 7 oli jo varhain pyhä, sillä taivaalta tunnettiin aurinko, kuu ja viisi planeettaa ja jokaiselle kulkijalle haluttiin nimetä oma päivä.

- vuorokausi, aika auringonnoususta seuraavaan auringonnousuun tai laskusta laskuun. Roomalaiset ottivat käyttöön tavan aloittaa uusi vuorokausi keskiyöllä.

- tunti, vuorokauden kahdeskymmenesneljäsosa.

- minuutti, tunnin kuudeskymmenesosa. Vanhassa Mesopotamiassa noudatettiin tuhansia vuosia sitten matematiikassa 60 -järjestelmää, ja sama jaotus on edelleen lyhimmissä aikamitoissa. 
- sekunti, minuutin kuudeskymmenesosa. Nykyisin sekunti on ajan perusmitta, ja sen pituus määritellään atomien värähtelyn avulla.

Ajanlaskun ja kalenterien kehitys nykyiseen muotoonsa on ollut hyvin polveilevaa, sillä luonto ei ole antanut meille ainoatakaan selvää ja itsestään sopivaa aikamittaa. Maapallon kierrossa auringon ympäri ei ole tasamäärä kuun jaksoja tai päiviä eikä kuun vaiheiden jaksossa tasamäärää vuorokausia.

Oikean ajan etsiminen on ollut tasapainottelua erilaisten huonojen vaihtoehtojen välillä, ja tuloksena on ollut erilaisia aikajärjestelmiä, erilaisia kompromisseja maapallon eri kulttuureissa.

Ajanlaskun avulla ihminen on vähitellen luonut itselleen yhä järjestetympää kuvaa maailmasta. Sirpaleiset tapahtumat eri puolilla maailmaa on koetettu saada samalle yhtenäiselle viivalle.

Ajanlasku on palvellut myös puhdasta käytännön tarvetta. Aluksi vuoden kiertoa käytettiin uskonnollisten juhlien järjestämiseen ja maanviljelyn avuksi. Myöhemmin ajanmittausta on käytetty mm. merenkulun apuna. Nyky-yhteiskunnassa oikean ajan tietäminen ja ylläpitäminen on kaiken toiminnan perusta, kun sekunnintarkat viestit viuhuvat ympäri maapalloa radion tai internetin välityksellä.

Kirjamme ensimmäisessä luvussa annetaan lyhyt vastaus puoleensataan keskeiseen kysymykseen, joita ajanlaskusta tai kalentereista jatkuvasti esitetään. Sitten seuraamme nykyisen kalenterimme kehitystä tuhansien vuosien takaa nykypäivään ja pohdimme tarkimman ajanmittauksen mutkia.

Kolmessa seuraavassa luvussa käymme läpi erilaisia merkkipäiviä vuoden varrella: ensiksi luonnon antamat merkkipäivät, toiseksi kirkolliset merkkipäivät ja kolmanneksi vielä yhteiskunnan merkkipäivät. Viimeisessä luvussa seuraamme suomalaisten almanakkojen ja kalenterien kehitystä.

Tämän kirjan aineisto on koottu vähitellen sen neljännesvuosisadan aikana, jonka olen toiminut almanakkatehtävissä Helsingin yliopiston tähtitieteen laitoksessa ja sittemmin almanakkatoimistossa. Osa kirjasta perustuu 1980-luvun alussa julkaistuun kirjaani Allakkatieto, mutta suurin osa on uutta aineistoa.

Kiitän kaikkia niitä kyselijöitä ja keskustelijoita, jotka ovat vuosien varrella halunneet tietoa erilaisista kalenteriasioista. Näiden kyselyjen takia olen joutunut penkomaan tietoja monenlaisista lähteistä, pölyisistä kirjoista internetin uusimmille sivuille.

Lausun myös parhaat kiitokset seuraaville henkilöille, jotka olivat avuksi kirjan teon eri vaiheissa: Sami Feiring, Arno Forsius, Arja Latvala, Tapio Mansten, Jyrki Molin, Risto O. Nykänen, Saku Oja, Antti Pajala, Raili Pentti ja Jorma Räihä.

Taloudellista tukea ovat tälle työlle ystävällisesti myöntäneet Suomen Tietokirjailijat, opetusministeriö ja Otavan Kirjasäätiö.

Helsingissä kesäkuussa 1999

Heikki Oja

\section{Aikakirja 2007, 2010 ja 2013}

Otava otti Aikakirjasta vuosina 1999-2000 kolme painosta. Kun kirja oli myyty loppuun vuonna 2004, ei uusia painoksia enää otettu ja kirjan julkaisuoikeus siirtyi takaisin kirjoittajalle.

Aikakirja sisältää keskeistä kalenteritietoa, josta Yliopiston almanakkatoimistoon tulee jatkuvasti kyselyjä. Siksi katsoimme, että kirja kannattaa pitää lukijoiden saatavilla, mutta nyt verkkoversiona. Niinpä Aikakirjaa on jatkuvasti päivitetty ajan tasalle. Ensimmäinen verkkoversio oli nimeltään Aikakirja 2007, seuraava Aikakirja 2010 ja nyt käsillä oleva on Aikakirja 2013.

Kiitän kaikkia, jotka lähettivät arvokkaita kommentteja Aikakirjan aikaisemmista painoksista. Ehdotukset on koetettu ottaa mahdollisuuksien mukaan huomioon. Uudet ehdotukset ja kommentit ovat tervetulleita osoitteeseen almanakka@helsinki.fi.

Helsingissä maaliskuussa 2013

\section{Heikki Oja}




\section{50 KYSYMYSTÄ AJASTA JA KALENTERISTA}

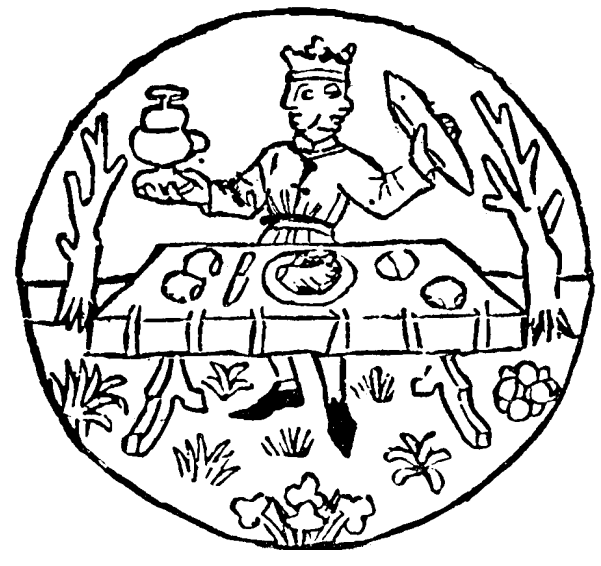

Tammikuun askareita keskiaikaisessa almanakassa: Juodaan. Yksityiskohta Johannes von Gmundenin kalenterista (ks. s. 42).

\section{Auringon nousut ja laskut}

Lasketaanko auringon nousu- ja laskuajat auringon yläreunan vai keskipisteen mukaan?

Yläreunan mukaan. Vuoteen 1974 asti suomalaiset almanakat ilmoittivat ajat keskipisteen mukaan, mutta vuodesta 1975 alkaen siirryttiin kansainväliseen käytäntöön ja ruvettiin ilmoittamaan ajat yläreunan mukaan.

\section{Betlehemin tähti}

Onko kertomus Betlehemin tähdestä totta vai tarua?

Vastausta ei tiedetä. Raamatun kertomus saattaa viitata todelliseen tähtitaivaan ilmiöön, jonka merkitystä on suurenneltu asian tärkeyden vuoksi. (Ks. s. 162.)

\section{GMT ja UTC}

Mitä eroa on GMT:llä ja UTC:llä?

Greenwichin keskiaurinkoajasta (GMT) luovuttiin vuonna 1972, jolloin otettiin käyttöön koordinoitu yleisaika (UTC). Käytännössä ne tarkoittavat suunnilleen samaa, mutta UTC on vanhan GMT:n tarkempi muoto. (Ks. s. 100.) 


\section{Jaksollisuus}

Onko ajanlaskussa jokin jakso, jonka kuluttua vuodet toistuvat samanlaisina?

Kullakin vuosisadalla vuodet toistuvat viikonpäivien suhteen samanlaisina 28 vuoden jaksossa, mutta vuosisadan vaihde katkaisee tämän jakson. Seuraava pitempi jakso ei katkea: vuodet toistuvat viikonpäivien suhteen täsmälleen samanlaisina 400 vuoden välein. Jos otetaan mukaan myös pääsiäisen paikka, toistuu gregoriaaninen kalenteri juhlineen ja viikonpäivineen samanlaisena 5700000 vuoden jaksossa. Vanhassa juliaanisessa kalenterissa täydellisen jakson pituus oli paljon lyhempi, vain 532 vuotta.

\section{Jeesuksen syntymä ja kuolema}

Minä vuonna Jeesus syntyi?

Tarkkaa vuotta ei tiedetä, mutta Jeesuksen syntymä on todennäköisesti sattunut 2-7 vuotta ennen ajanlaskumme alkua. (Ks. s. 162.)

\section{Minä vuonna Jeesus kuoli?}

Raamatun pimennyskertomuksen perusteella ovat tähtitieteilijät arvioineet, että Jeesuksen kuolinpäivä oli 3. huhtikuuta vuonna 33. Kirkonmiehet arvioivat, että kuolinvuosi on aikaisempi, luultavasti vuosi 30 , jolloin pitkäperjantain päivämäärä oli 7.4. (Ks. s. 153.)

\section{Juhannus}

Milloin juhannus siirrettiin viikonloppuun?

Juhannuspäivä oli vuoteen 1954 asti kiinteällä paikalla 24.6., ja vuodesta 1955 alkaen juhannuspäivä on ollut kesäkuun 20. ja 26. päivän väliin sattuvana lauantaina.

Miksi juhannuspäivä on 24. kesäkuuta, mutta joulupäivä 25. joulukuuta?

Perinteen mukaan Jeesuksen ja Johannes Kastajan syntymäpäivien väli oli puoli vuotta. Päivien paikat määräytyivät Roomassa, jossa kuukaudenpäivät numeroitiin eri tavalla kuin meillä. Kumpikin päivä oli (roo- malaisen laskutavan mukaan) kahdeksantena päivänä (nykyisen laskutavan mukaan seitsemäntenä) ennen seuraavan kuun 1. päivää, joten Roomassa niiden väli oli tasan puoli vuotta. (Ks. s. 158.)

\section{Kalenterin julkaiseminen}

Yhdistyksemme haluaa tehdä oman kalenterin. Onko kalenterin julkaisemisessa vielä joitakin rajoituksia?

Jos kalenterissa ei käytetä nimipäiviä, ei vuoden 1995 jälkeen ole kalenterien teossa ollut mitään rajoituksia. Kalenterin voi julkaista millä kielellä haluaa, siihen voi vapaasti merkitä suomalaiset juhlapäivät ja sen voi painattaa missä haluaa. Nimipäiviin on kuitenkin Helsingin yliopistolla tekijänoikeus ja niiden julkaisemisesta peritään korvaus. Almanakkatoimiston esite ja hinnasto löytyy internetistä osoitteesta http://almanakka. helsinki.fi.

\section{Karkauspäivä}

Miksi karkauspäivä oli aikaisemmin suomalaisissa almanakoissa 24. helmikuuta eikä 29. helmikuuta?

Julius Caesar määräsi karkauspäivän paikan 2000 vuotta sitten uusiessaan roomalaista kalenteria. Vanha vuodenvaihde oli maaliskuun alussa. Aikaisemmin Roomassa oli käytetty kokonaisia karkauskuukausia. Silloin helmikuu katkaistiin 23. päivän jälkeen ja sen jatkoksi vuoden loppuun sijoitettiin karkauskuukausi. Kun Caesar antoi määräyksen karkauspäivistä, hän sijoitti ne samalle kohdalle kuin aiemmat karkauskuukaudet. Vuodesta 2000 alkaen ei Suomessakaan enää ole noudatettu Caesarin määräystä, vaan karkauspäivä on 29.2. (Ks. s. 52.)

\section{Karkaussekunnit}

Miksi aikaan lisätään karkaussekunteja?

Maapallon pyöriminen on vähitellen hidastumassa, kun taas kellojen näyttämä aika etenee tasaisesti atomikellojen tahtiin. Jotta kellojen näyttämä aika pysyisi tahdissa myös vuorokaudenaikojen suhteen, joudutaan aikaan lisäämään muutaman vuoden välein karkaussekunti. (Ks. s. 101.) 
Mistä alkaen Suomen aikaan on liitetty karkaussekunteja?

Vuodesta 1972, jolloin otettiin käyttöön koordinoitu maailmanaika UTC. (Ks. s. 101.)

\section{Karkausvuosi}

Oliko vuosi 2000 karkausvuosi?

Oli. Gregoriaanisen kalenterimme karkausvuosisääntö sanoo, että joka neljäs vuosi on karkausvuosi. Poikkeuksena ovat täydet vuosisadat, jotka yleensä eivät ole karkausvuosia; esim. 2100 ei ole karkausvuosi. Poikkeuksen poikkeuksena ovat kuitenkin 400:1la jaolliset vuodet, jotka ovat karkausvuosia. (Ks. s. 43.)

\section{Kesäaika}

Miksi kesäaika on otettu käyttöön?

Keski-Euroopassa ruvettiin käyttämään kesäaikaa energiansäästön takia. Ihmisten elämänrytmi on muuttunut sellaiseksi, että ihmiset valvovat pitkään illalla ja käyttävät keinovaloa. Sähkön käyttö saadaan pienenemään, kun pimeä iltatunti vaihdetaan valoisaan aamutuntiin. Suomessa on kesäkuukausina valoisaa niin illalla kuin aamulla, mutta syksyllä ja keväällä kesäaika säästää meilläkin energiaa. Suomi otti kesäajan käyttöön lähinnä sen vuoksi, että aikaero tärkeimpiin kauppakumppaneihin pysyisi koko ajan samana. Nykyään kesäaika on päätetty EU-maiden yhteisellä sopimuksella. (Ks. s. 103.)

Mistä alkaen Suomessa on käytetty kesäaikaa?

Kesäaikaa kokeiltiin meillä toisen maailmansodan aikana 1942, mutta kokeilu jäi yksivuotiseksi. Uudelleen kesäaika otettiin käyttöön vuonna 1981, ja siitä alkaen sitä on käytetty joka vuosi. (Ks. s. 105.)

Milloin siirrytään kesäaikaan ja siitä pois?

Kesäaikaan siirrytään maaliskuun viimeisenä sunnuntaiaamuna, jolloin kellot siirretään 03:sta 04:ään, ja normaaliaikaan palataan lokakuun viimeisenä sunnuntaiaamuna, jolloin kellot siirretään 04:stä 03:een. (Ks. s. 106.)

\section{Nimipäivät}

Kuka päättää, mitkä nimet ovat almanakassa?

Helsingin yliopisto pitää yllä almanakan nimiluetteloa. 1980-luvulta vuoteen 2010 asti suomalaisista nimistä vastasi professori Eero Kiviniemi. Vuoden 2010 alusta lähtien suomalaisesta nimilistasta vastaa dosentti Minna Saarelma-Paukkala. Suomenruotsalaisista nimistä on 1990-luvulta alkaen vastannut professori Marianne Blomqvist. Muodolliset päätökset nimistä tekee yliopiston rehtori. (Ks. s. 209.)

Voidaanko miesten ja naisten nimiä sijoittaa samalle päivälle?

Nykyään sille ei ole mitään estettä. Aikaisemmin vain Aatami ja Eeva olivat samalla päivällä, mutta viime aikoina on nimiuudistuksissa tullut sellaisia pareja kuin Erik ja Erika, Mikael ja Mikaela, jopa Suvi ja Roope tai Arja ja Lenni. Vuonna 2013 on suomalaisessa almanakassa ainakin 15 päivää, jolloin on sekä naisten että miesten nimiä.

Annoimme pojalle nimeksi Peetu. Milloin nimi pääsee almanakkaan? Väestörekisterikeskuksen sivulta www.vaestorekisterikeskus.fi löytyy nimipalvelu, josta näkyvät eri etunimien yleisyydet. Vuoden 2012 lopulla Peetu-nimisiä oli Suomessa yli 1300 kappaletta. Almanakkaan pääsemiseksi täytyy nimellä olla nykyään noin 500 suomenkielistä kantajaa, joille nimi on annettu ensimmäiseksi etunimeksi vuoden 1960 jälkeen. Peetu on ylittänyt tämän rajan, joten se pääsee luultavasti mukaan seuraavassa nimiuudistuksessa, joka tehdään vuoden 2015 almanakkaan.

\section{Milloin Reeti voi viettää nimipäiväänsä?}

Jos nimi ei ole almanakassa, nimipäivä määräytyy kantanimen mukaan. Reeti on samaa perua kuin Alfred ja Fredrik, ja siksi nimipäiväksi sopii Alfredin päivä 29.10. Useat harvinaiset nimet ovat sellaisia, että niille ei pysty osoittamaan omaa nimipäivää. Epävirallisen nimipäivän voi valita vaikkapa samalta kuulostavien tai samalla tavalla alkavien nimien mukaan. 


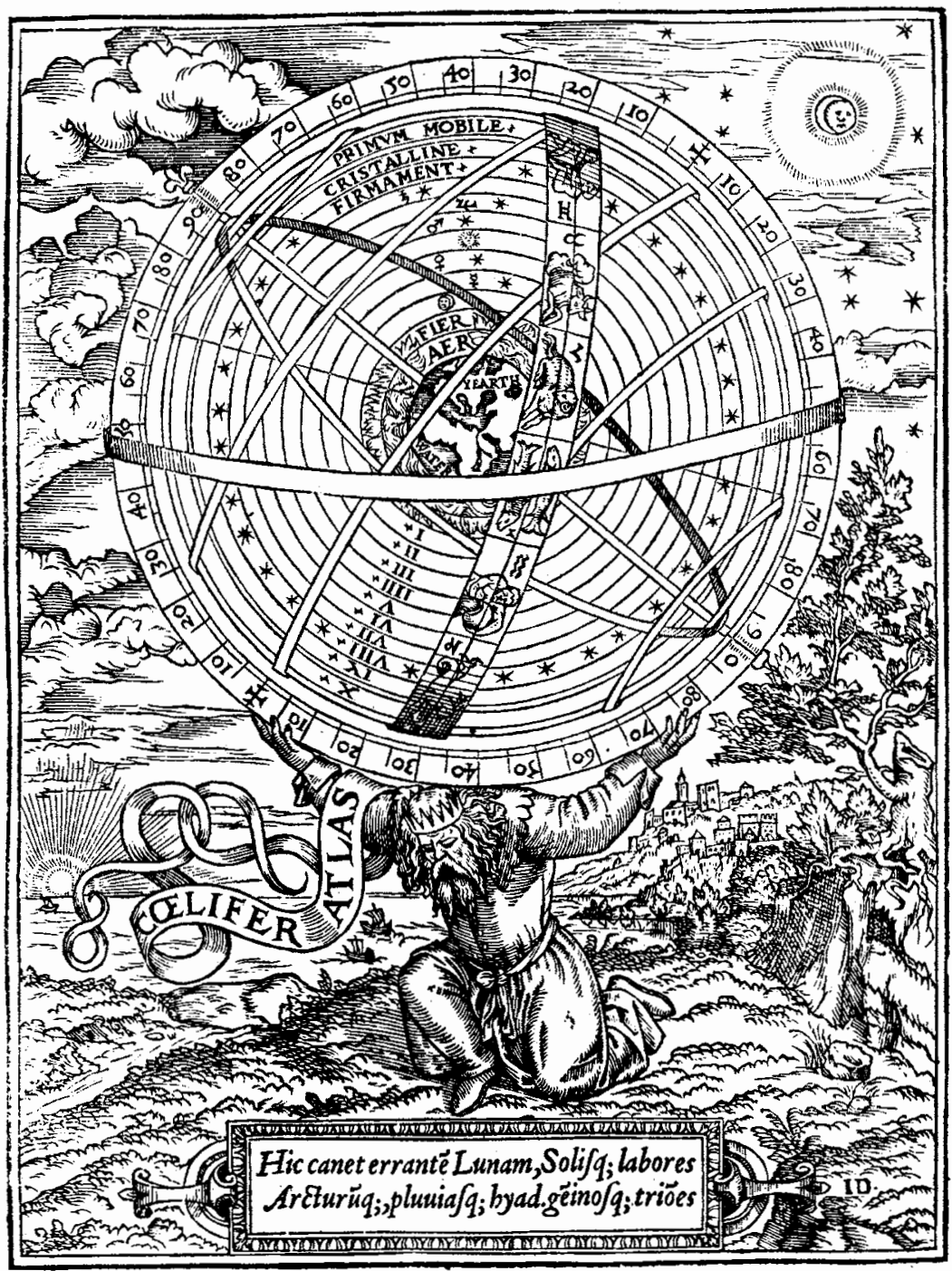

Atlas kantaa selässään maailmaa. Keskiaikainen puupiirros.

\section{Perjantai ja 13. päivä}

Onko totta, että kalenterissamme kuukauden 13. päivä on useammin perjantai kuin mikään muu viikonpäivä?

On. Kalenterin viikonpäivät toistuvat 400 vuoden jaksossa, ja 400 vuodessa on yhtä paljon kaikkia viikonpäiviä. Viikonpäivät ovat jakautuneet kuitenkin hieman epätasaisesti eri kuukaudenpäiville. Kuukauden 13. päivä on tavallisimmin perjantai ja esimerkiksi 31. päivä on tavallisimmin torstai. (Ks. s. 49-51.) - Perjantai ja 13. päivä sattuu joka vuosi vähintään kerran ja enintään kolme kertaa.

\section{Viikko}

Miksi viikko alkaa maanantaina eikä sunnuntaina?

Kyseessä on kansainvälinen standardi, joka vahvistettiin 1970-luvun alussa. Sen mukaan viikon ensimmäinen päivä on maanantai. Helsingin yliopiston päätöksellä vuoden 1973 alusta lähtien suomalaisissa kalentereissa on noudatettu kansainvälistä standardia. Aikaisemmin pidettiin usein sunnuntaita viikon ensimmäisenä päivänä, ja samaa käytäntöä näkee edelleen esimerkiksi amerikkalaisissa kalentereissa. (Ks. s. 46-47.)

\section{Viikkonumero}

Miten viikkonumerot määräytyvät?

Laskeminen aloitetaan vuoden alusta. Viikko 1 on se viikko, joka sisältää vuoden ensimmäisen torstaipäivän. Seuraavat viikot saavat numeron 2 , 3 jne. (Ks. s. 47.)

\section{Käytetäänkö Amerikassa viikkonumeroita?}

Yleensä ei, ja jos käytetään, numerointi voi poiketa kansainvälisestä standardista. Esimerkiksi eräät amerikkalaiset tietokoneohjelmat merkitsevät vuoden ensimmäisen päivän aina viikolle 1 , vaikka se voi todellisuudessa olla myös viikkoa 52 tai 53 .

Milloin vuodessa on 53 viikkoa?

Jos tavallinen vuosi alkaa torstailla ja karkausvuosi keskiviikolla tai tors- 
tailla, vuoteen tulee 53 viikkoa. Seuraavat 53-viikkoiset vuodet ovat 2015 ja 2020.

\section{Viikonpäivä}

Mikä viikonpäivä oli 20.5.1945?

Sunnuntai. Vastauksen löytää almanakka-arkistosta (http://almanakka. helsinki.fi/arkisto), josta löytyvät skannattuina eri vuosien suomalaisalmanakat.

Onko totta, että vuonna 1963 syntyneet henkilöt voivat viettää 50-vuotispäiviään 2013 samana viikonpäivänä kuin olivat syntyneet?

On. Vuonna 2013 viikonpäivät toistuvat täsmälleen samalla tavalla kuin 1963. Tämä ei kuitenkaan päde kaikille vuosille. 2000-luvun toisella vuosikymmenellä voivat 50 -vuotispäiväänsä viettää alkuperäisillä viikonpäivillä kaikki vuosina 1963 ja 1967 syntyneet henkilöt sekä osa vuosina 1962, 1964, 1966, 1968 ja 1970 syntyneistä, mutta ei kukaan vuosina 1961, 1965 tai 1969 syntyneistä. Kaiken kaikkiaan puolet ihmiskunnasta voi viettää 50 -vuotispäiviään samana viikonpäivänä kuin on syntynyt, toinen puoli ei.

\section{Viikonloppu}

Miten viikonloppu määritellään? Elatussopimuksessa on lapsen tapaminen sovittu kuukauden ensimmäiseksi ja kolmanneksi viikonlopuksi. Kun kuukausi katkeaa lauantain ja sunnuntain välistä, onko kyseessä edellisen kuukauden viimeinen vai alkavan kuukauden ensimmäinen viikonloppu?

Viikonlopulla ei ole yksikäsitteistä määritelmää. Siksi sopimuksissa ei pidä käyttää sanontaa "kuukauden ensimmäinen viikonloppu", vaan määrätä tapaaminen esimerkiksi

- joka toiseksi viikonlopuksi

- parillisten tai parittomien viikkojen viikonlopuiksi

- sellaisiksi viikonlopuiksi, jotka sisältävät kuukauden ensimmäisen ja

kolmannen sunnuntain. (Ks. s. 49.)

\section{Vuosituhat}

Milloin vuosituhat vaihtui?

Vuoden 2001 alussa. Ajanlaskussamme ei ole vuotta nolla, vaan ajanlasku alkoi vuoden 1 alussa. Siksi kolmas vuosituhat alkoi vuoden 2001 alussa. Tavallisessa kielenkäytössä vuosituhannella tarkoitetaan kuitenkin jaksoa 1000-1999, joten uuden vuosituhannen alkua juhlittiin jo vuoden 2000 alussa. (Ks. s. 50.) Vastaavasti vuosikymmenet vaihtuvat tarkkaan ottaen silloin, kun vuosiluvun 0 vaihtuu ykköseksi. Käytännössä uuden vuosikymmenen voi hyvin aloittaa jo vuotta aikaisemmin.

Kuinka suuri osa maapallosta elä̈ nyt vuotta 2013?

Noin puolet. Maapallon seitsemästä miljardista ihmisestä runsaalla kolmella miljardilla on virallisena kalenterinaan länsimainen gregoriaaninen kalenteri. Loput noudattavat islamilaista, intialaista tai muuta kalenteria, jossa on menossa muunnumeroinen vuosi. (Ks. s. 21.) 


\section{AJANLASKUN AAKKOSIA}

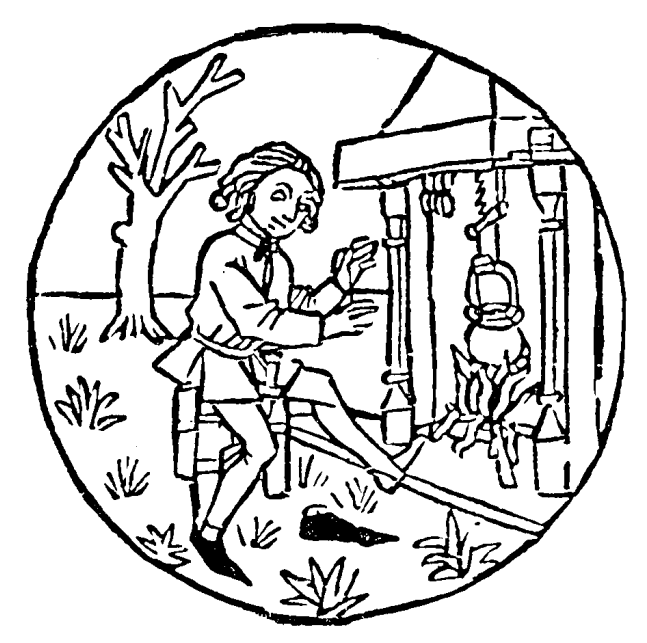

Helmikuun askareita Johannes von Gmundenin kalenterissa: Poltetaan puita.
1 jan mittaaminen on perinteisesti jaettu kahteen eri osaan. 1 Toinen käsittelee päivää pitempiä ajanjaksoja ja sitä sanotaan ajanlaskuksi. Sen tuotteita ovat kalenterit, joista voimme seuluvussa käsittelemme nimenomaan ajanlaskun ja kalenterien kehitystä.

Toinen osa käsittelee päivää lyhempiä ajanjaksoja ja sitä sanotaan ajanmittaukseksi. Ajanmittaajan tärkein työväline on kello, joka kertoo tuntien, minuuttien ja sekuntien kulun. Omistamme ajanmittaukselle kirjamme seuraavan, kolmannen luvun.

\section{Monesko vuosi nyt on?}

Ennen kuin lähdemme tarkemmin pohtimaan kalenterinteon periaatteita ja kalenterien kehitystä, luomme nopean silmäyksen maapallon erilaisiin kalentereihin. Voimme katsoa, monesko vuosi kussakin aikajärjestelmässä on näinä aikoina menossa.

Suurin vuosiluku löytyy itäisen ortodoksisen kirkon piiristä. Siellä on arveltu maailman luomisen tapahtuneen runsaat 7000 vuotta sitten, ja niinpä vuoden 2013 syyskuun 14. päivänä alkaa siellä vuosi 7522 .

Toiseksi vanhin alkukohta on hyvin tieteellisellä ajanlaskutavalla, ns. juliaanisten päivämäärien laskemisella. Kuten myöhemmin näemme, tässä ajanlaskussa ei lasketa vuosia, vaan pelkkiä peräkkäisiä vuorokausia. Juliaaninen vuorokausi nolla alkoi vuoden $4713 \mathrm{eKr}$ tammikuun 1. päivänä eli yli 6700 vuotta sitten.

Myös juutalaiset laskevat itäisten ortodoksien tavoin aikaa maailman luomisesta, mutta heidän mukaansa luominen tapahtui runsaat viisituhatta vuotta sitten. Syyskuun 4. päivän iltana 2013 alkaa juutalaisten vuosi 5774. 
Länsimaisen ajanlaskun alkukohta, vuoden 1 tammikuun 1. päivä, koetettiin ajoittaa Jeesuksen syntymän tienoille. Nykyinen gregoriaaninen kalenterimme on perintöä keisari Julius Caesarilta runsaan kahdentuhannen vuoden takaa ja paavi Gregorius XIII:Ita 1500-luvulta.

Islaminuskoiset laskevat vuosia siitä päivästä, jolloin profeetta $\mathrm{Mu}$ hammed pakeni Mekasta Medinaan (meidän ajanlaskumme mukaan) heinäkuun 16. päivänä 622. Vuoden 2013 marraskuun 4. päivän iltana alkaa islamilaisten vuosi 1435. (Tarkkaavainen lukija huomaa heti, että $622+1435$ on reilusti suurempi kuin 2013. Tämä johtuu siitä, että islamilainen vuosi on lyhempi kuin länsimainen vuotemme.)

Kiinalaisessa ajanlaskussa ei lasketa vuosilukuja kuten meillä, vaan vuodet toistuvat 60-vuotisessa jaksossa. Helmikuun 10. päivänä vuonna 2013 alkoi kiinalaisilla nykyisen jakson vuosi 30 (nimeltään gui-si), joka on omistettu käärmeelle. Edellinen oli lohikäärmeen vuosi, ja käärmeen jälkeen on vuorossa hevosen vuosi.

Maapallon uusimpia kalentereita on Ranskan vallankumouksen kalenteri, joka hyväksyttiin 1793. Sen alkukohta oli kuningaskunnan syrjäyttämispäivä 22. syyskuuta 1792. Syksyllä vuonna 2013 alkaisi vallankumouskalenterin vuosi 222 . Mutta valitettavasti (tai onneksi?) jo Napoleon hylkäsi vallankumouskalenterin, joka ehti olla voimassa Ranskassa vain viitisentoista vuotta.

\section{Taivaan kellot}

Kalenterin teossa on vaikeutena se, että yön ja päivän vaihtelu eli vuorokausi, kuun vaiheiden vaihtelu eli kuukausi ja vuodenaikojen vaihtelu eli vuosi eivät ole yhteismitallisia.

Jos maapallollamme kuun vaiheiden jakso olisi esimerkiksi tasan 35 vuorokautta ja vuoden pituus tasan 350 vuorokautta, olisi kalenterin teko helppoa. Joka vuosi olisi täsmälleen 10 kuukautta, ja kuun vaiheet toistuisivat joka kuukausi ja joka vuosi täsmälleen samanlaisina. Koska kuukauden pituus 35 vuorokautta olisi vielä tasan jaollinen 7:llä, saataisiin jokaiseen kuukauteen viisi viikkoa ja viikonpäivät toistuisivat joka kuukausi samoilla päivämäärillä.

Luonto on kuitenkin halunnut tehdä asiat ihmisille mutkikkaammiksi. Kuukauden pituus on noin 29,531 vuorokautta ja vuoden pituus 365,242 vuorokautta. Näitä numeroarvoja ei tietenkään saatu heti sel- ville, vaan ensimmäisissä kalentereissa jouduttiin turvautumaan epätarkempiin lukuihin.

Kuun vaiheiden jakso on melko helppo arvioida, kun tarkkailee niitä aikoja, jolloin kuu katoaa näkyvistä ja ilmestyy sitten uudelleen esiin aivan ohuena sirppinä. Jo viitisentuhatta vuotta sitten tiedettiin, että kuu syntyy noin 29,5 vuorokauden välein.

Vuoden tarkan pituuden määrääminen on vaikeampaa. Näemme kyllä, että auringon korkeus taivaalla vaihtelee, ja jos teemme havaintoja aina samalta paikalta, huomaamme että sen nousu ja lasku tapahtuvat eri vuodenaikoina eri kohdissa taivaanrantaa. Muutokset ovat kuitenkin

Kuu ilmestyy

iltataivaalle vajaa vuorokausi sen jälkeen kun se on ohittanut

auringon. Aluksi kuu näkyy hyvin kapeana sirppinä laskeneen auringon yläpuolella taivaanrannassa. Seuraavina iltoina kuu pulskistuu kohti puolikuuta. Kuvassa vajaan vuorokauden ikäinen

kuu. (Kuva Pekka Parviainen, www. polarimage.fi)

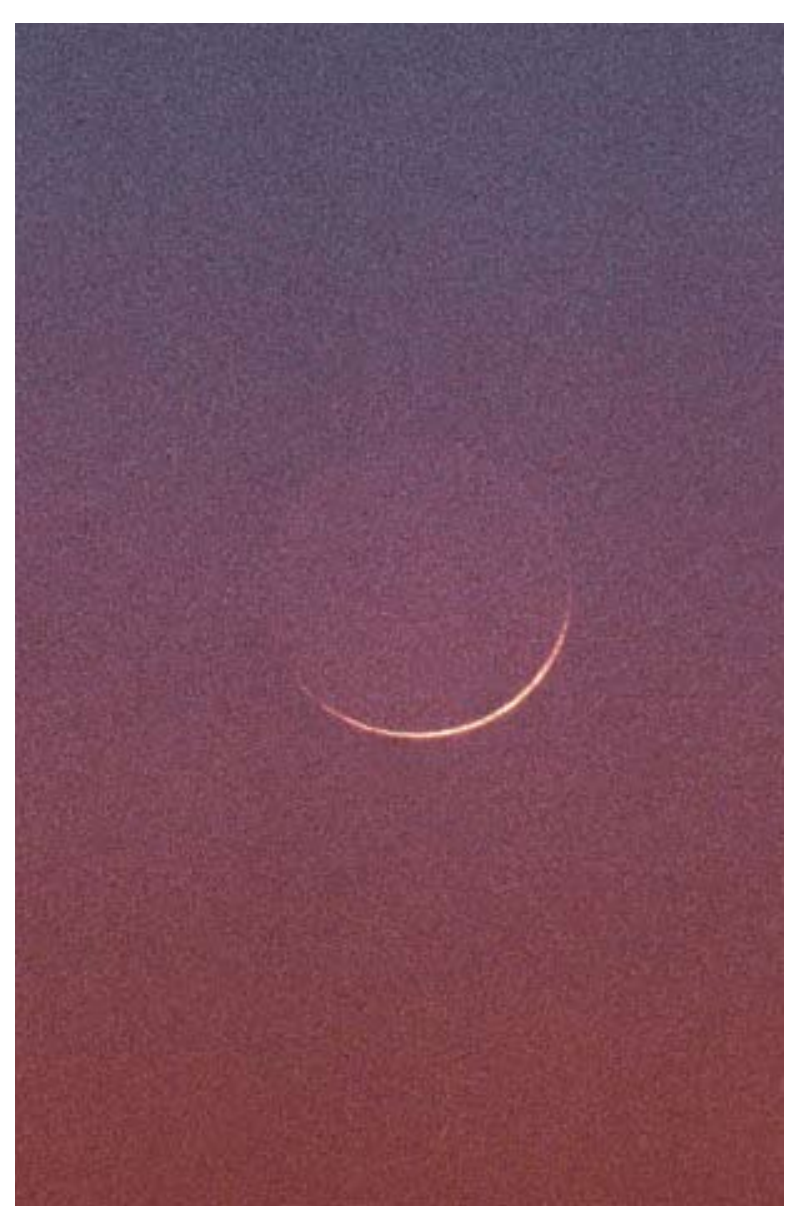


niin vähittäisiä, että on vaikea sanoa, milloin auringon kierto on palannut täsmälleen lähtökohtaansa.

Ensimmäisissä arvioissa vuoden pituudeksi otettiin 360 vuorokautta. Tämä luku on säilynyt astelevyissä, joissa täysi ympyrä nykyäänkin jaetaan juuri 360 asteeseen. Mutta pian huomattiin, että todellisuudessa vuoden kierto on viitisen päivää pitempi.

\section{Kuukalenteri ja aurinkokalenteri}

Maapallon eri puolilla käytetyt kalenterit voidaan jakaa kahteen päätyyppiin sen mukaan, halutaanko ajanlaskussa noudattaa pääasiassa kuun rytmiä vai auringon rytmiä. Puhutaan kunkalentereista ja aurinkokalentereista.

Kuukalenterissa lasketaan todellisia kuun jaksoja. Uusi kuukausi alkaa aina kuun syntyessä. Nykyään uudenkuun hetkeksi lasketaan se täsmällinen kellonaika, jolloin kuu on juuri auringon suunnassa ja siten kokonaan näkymätön. Tämä hetki pystytään helposti laskemaan, koska maapallon ja kuun liikkeet tunnetaan hyvin tarkasti.

Viisituhatta vuotta sitten ei tiedetty, mistä kuun vaiheet johtuivat, ja voitiin vain tehdä havaintoja kuun vaihtuvasta muodosta. Uuden kuukauden laskettiin alkavan siitä hetkestä, jolloin kuunsirppi ensimmäisen kerran ilmestyi taivaalle.

Jos laskemme peräkkäin kaksitoista kuukautta, joista jokaisen pituus on 29,5 päivää, pääsemme 354 päivään. Tämä on suunnilleen vuoden pituus. Jos otamme mukaan vielä kolmannentoista kuukauden, olemme jo 383,5 päivän päässä lähtöhetkestä. Jo varhain huomattiin, että kolmentoista kuukauden jakso on selvästi pitempi kuin yksi auringon kierto, ja siksi kuukalenterissa vuoteen valittiin 12 kuukautta.

Tällainen oli ensimmäinen kuukalenteri: kaksitoista kuukautta, jotka olivat vuorotellen 29 ja 30 päivän mittaisia, ja vuoden pituus oli 354 päivää.

Koska kuukalenterin vuosi on selvästi lyhempi kuin aurinkovuosi, siirtyy vuoden alku hiljakseen toiseen paikkaan vuodenaikojen suhteen. Yhdessä vuodessa siirtymä on 11 vuorokautta ja kymmenessä vuodessa jo 110 vuorokautta. Jos vuoden alku oli jonakin hetkenä talvella, kymmenen vuoden päästä se on vaeltanut taaksepäin syksyyn tai loppukesään. Ja runsaassa kolmessakymmenessä vuodessa kuuvuoden alku on vaeltanut koko aurinkovuoden ympäri ja palannut taas samaan vuodenaikaan.

Kuukalentereita otettiin käyttöön sellaisissa maissa, joissa ilmasto pysyy suunnilleen samanlaisena ympäri vuoden. Silloin ei ole niin suurta väliä, missä vuoden alku kulloinkin on.

Aito kuukalenteri on nykyään esimerkiksi islamilaisissa maissa. Arabian niemimaalla tai Saharan hiekka-aavikoilla aurinko paistaa ympäri vuoden yhtä kuumana, ja vain kuun vaihteleva ulkonäkö yön pimeydessä tuo aikaan rytmin, jonka mukaan päiviä lasketaan.

Toisin on tilanne niissä maissa, joissa eri vuodenajoilla on jyrkät erot. Silloin kalenteri halutaan tehdä nimenomaan vuodenaikoja noudattavaksi ja kuun vaiheet jätetään vähemmälle huomiolle.

Esimerkiksi nykyinen länsimainen kalenteri on puhdas aurinkokalenteri, jossa noudatetaan vain auringon jaksoa. Vuosi on kyllä edelleen jaettu kahteentoista kuukauteen, mutta kuukausilla ei nimestään huolimatta ole enää mitään tekemistä kuun vaiheiden kanssa.

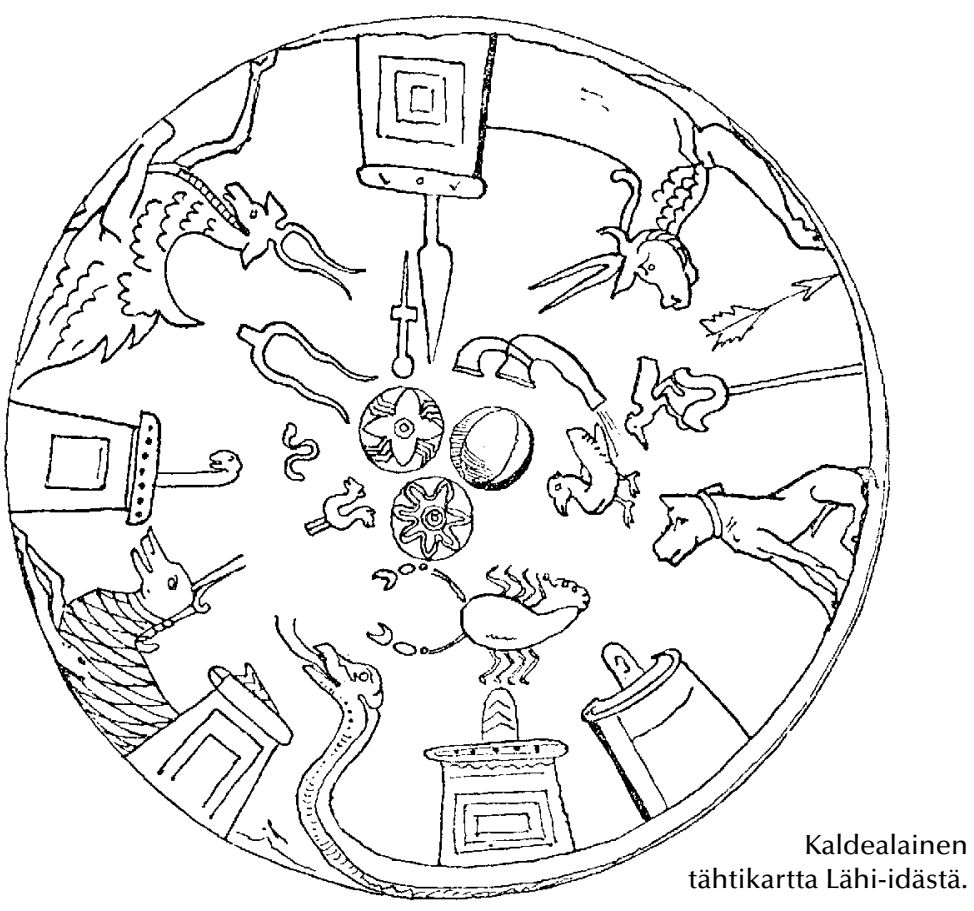


Kolmas mahdollisuus kalenterinteossa on ns. sekakalenteri eli kuuaurinkokalenteri, jossa seurataan kumpaakin taivaallista ajannäyttäjää. Kuukaudet ovat todellisia kuun vaiheiden jaksoja, mutta myös vuosi noudattaa pitemmän päälle todellisia vuodenaikoja. Tähän päästään lisäkuukausien, ns. karkauskuukausien avulla. Suunnilleen joka kolmas vuosi pannaan vuoteen 13 kuukautta normaalin kahdentoista sijaan, ja näin saadaan vuoden alku pysymään aina samassa vuodenajassa. Nykyaikana kuu-aurinkokalenteria käyttävät $\mathrm{mm}$. juutalaiset ja kiinalaiset. Heillä vuoden alku heilahtelee noin kuukauden sisällä, juutalaisilla syksyllä, kiinalaisilla talvella, mutta ei siirry kauemmaksi paikaltaan.

Ensimmäiset luotettavat kalenterit kehitettiin viitisentuhatta vuotta sitten kahdessa paikassa maapallolla, Kiinassa ja Lähi-idässä. Käsittelemme kiinalaisen ajanlaskun myöhemmin erikseen, koska sen kehitys kulki omia ratojaan eikä se ole antanut vaikutteita nykyiseen länsimaiseen kalenteriin. Meidän ajanlaskumme on monien mutkien kautta kehittynyt Egyptin vanhasta kalenterista.

\section{Egyptiläinen kalenteri}

Nykyinen ajanlaskutapamme perustuu kalenteriin, jonka egyptiläiset kehittivät jo parituhatta vuotta ennen Kristusta.

Egyptiläisten vuodessa oli 12 kuukautta, jotka aluksi noudattivat todellisen kuun vaiheita. Uusi kuukausi alkoi aina kun kuunsirppi uudenkuun jälkeen ensimmäisen kerran ilmestyi taivaalle. Koska 12 kuun jaksoa kestää yhteensä noin 354 vuorokautta, ei niiden avulla vielä päästä täyteen vuoteen. Aluksi saatettiin ottaa avuksi ylimääräisiä karkauskuukausia, kuten muissa kulttuureissa, mutta jo paljon ennen ajanlaskumme alkua keksittiin toisenlainen ratkaisu: kuukausissa ei enää noudatettu kuun todellisia jaksoja, vaan kuukauden pituus oli aina 30 päivää.

Tämä oli selkeä poikkeama luonnon antamista jaksoista, mutta sen avulla päästiin yksinkertaisempaan kalenteriin. Kun laskettiin peräkkäin 12 kappaletta 30-päiväisiä kuukausia ja lisättiin loppuun viisi ylimääräistä päivää, saatiin niistä yhteensä 365-päiväinen vuosi.

Egyptiläiset saivat jo varhain selville vuoden pituuden tarkkailemalla Niilin tulvia ja taivaan kirkkaimman tähden, Sothiksen (nykyisin Siriukseksi kutsutun) näkyvyyttä.

Sirius on useita viikkoja näkymättömissä, kun aurinko kulkee vuosit-
Egyptiläinen tähtitaivas kuninkaiden laaksossa olevassa hautaholvissa. Kartta on tehty noin vuonna $1460 \mathrm{eKr}$



taisella kierrollaan sen editse. Kun Sirius on auringon lähellä, auringon hehku peittää sen heikomman valon. Mutta auringon ohituksen jälkeen Sirius jonakin aamuna ilmestyy taas näkyviin taivaalle. Tätä hetkeä sanotaan Siriuksen "heliakkiseksi nousuksi".

Siriuksen ilmestyminen näkyville ennusti Niilin tulvien pian alkavan. Egyptin maanviljelys perustui Niilin tulviin. Vuodenaikojen mukaiset sateet huuhtelivat Niilin latvoilla veteen hedelmällistä mutaa, jota tulva kuljetti Egyptiin. Tulvakauden jälkeen rantamaat olivat kosteina ja me- 
hevinä uusista ravinteista ja antoivat hyvän sadon.

Koska Niilin tulvat olivat egyptiläisille elintärkeät, niiden tuloa seurattiin hyvin tarkasti. Jo parituhatta vuotta ennen Kristusta oli Siriuksen heliakkisten nousujen ja Niilin tulvien todettu toistuvan noin 365 päivän välein. Kun päästiin muutamaa sataa vuotta Kristusta edeltävään aikaan, oli vuoden päivien lukumäärä tarkentunut 365,25 vuorokauteen.

Egyptiläisillä oli muuten kolme vuodenaikaa, ei neljää kuten meillä. Kukin vuodenaika kesti neljä kuukautta. Ensimmäinen vuodenaika oli tulviminen, toinen viljely ja kolmas sadonkorjuu, jolloin Niilin vedet olivat myös alimmillaan.

\section{Roomalaisten vanha kalenteri}

Vanhan kertomuksen mukaan roomalaisten kalenteri sai alkunsa Rooman perustajan Romuluksen määräyksestä. Tarkemman muodon kalenterille antoi Rooman toinen kuningas Numa Pompilius vuoden $700 \mathrm{eKr}$ paikkeilla.

Vuodessa oli 12 kuukautta, joiden pituudet olivat 29 tai 31 päivää. Roomalaiset pitivät parittomia numeroita onnekkaampina kuin parillisia, ja siksi yksikään vanhojen roomalaisten kuukausi ei ollut 30-päiväinen.

Numan vuoden pituus oli 355 vuorokautta, joten se noudatti suunnilleen oikeita kuun vaiheita, mutta ei pysynyt tahdissa vuodenaikojen kierron kanssa.

Viimeistään vuoden $450 \mathrm{eKr}$ paikkeilla ruvettiin joka toiseen vuoteen lisäämään karkauskuukausi, jotta vuodenajat pysyisivät kohdallaan. Karkausvuosina katkaistiin silloinen viimeinen kuukausi, helmikuu, 23-päiväiseksi ja karkauskuukausi liitettiin helmikuun jälkeen. Uusi vuosi alkoi seuraavan kuukauden, maaliskuun alusta.

Karkauskuukauden mukaanottamisesta päättivät kunakin vuonna paikalliset johtajat. He eivät aina muistaneet julistaa oikeisiin aikoihin karkausvuosia tai lisäilivät ylimääräisiä karkauskuukausia saadakseen lisää hallitusaikaa. Siksi ajanlasku meni sekaisin. Julius Caesarin tullessa Rooman hallitsijaksi olivat vuodenajat useita kuukausia väärässä paikassa. Uskonnolliset juhlat sattuivat liian varhaiseen aikaan, ja esimerkiksi joihinkin rituaaleihin tarvittavat viinit ja viljat eivät olleet vielä ollenkaan kypsyneet. Asiaan oli saatava parannus.
Julius Caesarin apuna uuden kalenterin suunnittelussa oli Sosigenesniminen kreikkalainen, joka oli kotoisin Aleksandriasta, Egyptistä. Hän tunsi egyptiläisen ajanlaskun ja tiesi vuoden oikean pituuden 365 1/4 vuorokautta.

Sosigeneen ohjeiden mukaisesti Julius Caesar sääti normaalivuoden pituudeksi 365 vuorokautta. Tähän hän pääsi jättämällä aikaisemmat 31-päiväiset kuukaudet maaliskuun, toukokuun, elokuun ja lokakuun ennalleen, pidentämällä aikaisemmista 29-päiväisistä kuukausista tammikuun, heinäkuun ja joulukuun 31-päiväisiksi ja huhtikuun, kesäkuun, syyskuun ja marraskuun 30-päiväisiksi. Helmikuu, vuoden viimeinen kuukausi, jätettiin 28-päiväiseksi. Näin kuukaudet saivat Julius Caesarin märäryksestä ne pituudet, jotka niillä edelleenkin on.

Jotta vuoden keskimääräinen pituus saatiin 365,25 päiväksi, oli joka neljänteen vuoteen lisättävä yksi karkauspäivä. Julius Caesar määräsi karkauspäivän paikan samaksi, johon oli aikaisemmin lisätty kokonaisia karkauskuukausia eli helmikuun 23. päivän jälkeen. Sama paikka säilyi karkauspäivällä yli 2000 vuoden ajan, esimerkiksi suomalaisissa ja ruot-

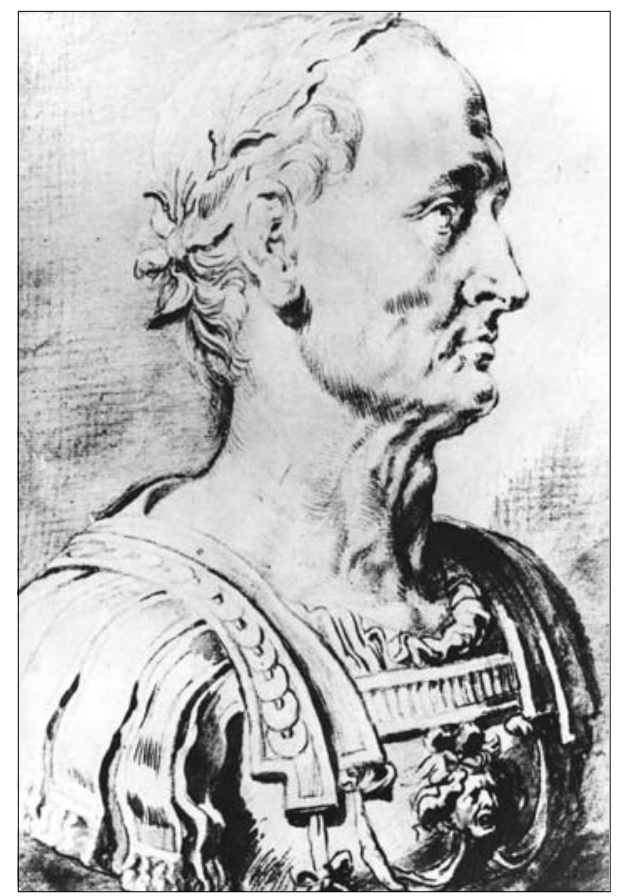

Roomalaisen kalenterin uudisti Julius Caesar vuonna 46 eKr. Nykyinen kalenterimme perustuu Caesarin säätämään ajanlaskuun. 




Roomalaiset nimesivät kuukautensa järjestyluvuilla tai jumalien mukaan. Kuvassa taivaallisia ja maanalaisia jumalia roomalaisesta mytologiasta. (Piirros Natalis Comesin kirjasta Mythologiae) salaisissa kalentereissa 1900-luvun loppuun asti.

Jotta vuodenajat saataisiin kohdalleen, Caesar joutui lisäämään vuoteen 46 eKr kokonaista kolme karkauskuukautta. Niistä yksi liitettiin entiseen tapaan helmikuun loppuun ja kaksi muuta sijoitettiin marraskuun ja joulukuun väliin. Näiden lisäysten jälkeen vuodenaikojen merkkipaalut, seisaukset ja tasaukset, olivat jälleen perinteisillä roomalaisilla paikoillaan seitsemän päivää ennen vuosineljännesten alkua eli meidän päivänumerointiamme käyttäen maaliskuun 25., kesäkuun 24., syyskuun 24. ja joulukuun 25. päivänä. (Nämä päivämäärät tuntuvat meistä nykyäänkin hyvin tutuilta, koska kristillinen kirkko antoi niille myöhemmin suuren uskonnollisen merkityksen: ne ovat Jeesuksen ja Johannes Kastajan siittämis- ja syntymäpäivät.)

Viimeisenä muutoksena Julius Caesar vahvisti vuoden alun tammikuun alkuun, kun se vanhimmissa roomalaisissa kalentereissa oli ollut maaliskuun alussa.

Julius Caesarin säätämää kalenteria ruvettiin kutsumaan juliaaniseksi ajanlaskuksi, ja sitä noudatettiin länsimaissa sellaisenaan yli 1600 vuotta.

Kalenterin alkuvaiheet kuitenkin kangertelivat, sillä roomalaiset ymmärsivät aluksi väärin karkausvuosisäännön. Roomalainen väliaikojen laskutapa oli sellainen, että esimerkiksi maanantaista keskiviikkoon laskettiin olevan kolme päivää: maanantai yksi, tiistai kaksi ja keskiviikko kolme. Siis kolme päivää.

Kun roomalaisille säädettiin, että joka neljäs vuosi piti olla karkausvuosi, he rupesivat laskemaan vuosia: tämä yksi, seuraava kaksi, seuraava kolme ja sitten neljä. Niinpä he rupesivat pitämään karkausvuosia joka kolmas vuosi. Keisari Augustus huomasi virheen ja jätti Kristuksen syntymän aikaan karkausvuosia pitämättä, kunnes vuodenajat olivat jälleen kohdallaan. Tämän jälkeen osattiin karkauspäivät lisätä oikein joka neljäntenä vuotena.

\section{Roomalaiset kuukaudennimet}

Paitsi nykyisiä kuukauden pituuksia, roomalaiset ovat antaneet useimmille länsimaille myös kuukausien nimet. Suomenkin kansa tuntee hyvin roomalaiset kuukaudennimet, sillä ne ovat olleet merkittyinä suomalaiseen almanakkaan ensimmäisistä vuosikerroista alkaen. 
Edelleenkin Yliopiston almanakka luettelee kuukausiaukeamillaan latinalaiset nimet suomalaisten rinnalla: Januarius, Februarius, Martius, Aprilis, Maius, Junius, Julius, Augustus, September, October, November ja December. Kahta lukuun ottamatta nämä ovat samat kuin Julius Caesarin aikoihin. Nuo kaksi poikkeusta ovat Julius ja Augustus, joiden nimenä Julius Caesarin eläessä oli Quintilis ja Sextilis.

Julius Caesarin kuoltua Rooman senaatti päätti ristiä Quintilis-kuukauden edesmenneen hallitsijan kunniaksi uudelleen Juliukseksi, ja seuraavaa keisaria Augustusta senaatti muisti myös samanlaisella lahjalla: Sextilis muutettiin Augustukseksi.

Mistä muut roomalaiset kuukaudet olivat saaneet nimensä? Loppuvuoden kuukausien nimitys on selvä: September on suomeksi seitsemäs, October kahdeksas, November yhdeksäs ja December kymmenes. Nimet ovat siten peräisin siltä ajalta, jolloin vuosi alkoi maaliskuun alussa. Quintilis (viides) ja Sextilis (kuudes) olivat myös pelkkiä järjestyslukuja, ennen kuin heinä- ja elokuu nimettiin hallitsijoiden mukaan.

Muista kuukaudennimistä Januarius viittaa kaksikasvoiseen Janus-jumalaan, joka katsoo sekä eteen- että taaksepäin. Nimi sopii hyvin vuoden aloituskuukaudelle. Martius on peräisin Marsista, sodanjumalasta. Maius on saanut todennäköisesti nimensä Maia-jumalattaresta ja Junius Juno-jumalattaresta. Februariksen ja Apriliksen alkuperää ei sen sijaan osata varmasti selittää.

Eurooppalaisista kielistä esimerkiksi hollannissa ja suomessa on omaperäiset kuukaudennimet, ja useimmat muut, myös virolaiset Suomenlahden eteläpuolella, käyttävät latinalaisista nimistä peräisin olevia muotoja.

\section{Roomalaisten päivänumerointi}

Kuukauden päivät numeroidaan nykyän kaikissa länsimaissa järjestyksessä yhdestä kolmeenkymmeneen (tai 31:een tai 28:aan, riippuen tietysti kuukauden pituudesta). Tämä tuntuu meistä ainoalta oikealta numerointitavalta.

Järjestyksessä numerointi on kuitenkin vajaa tuhat vuotta vanha keksintö. Koko ajanlaskumme ensimmäinen vuosituhat ja jo satoja vuosia aikaisemmin käytettiin toisenlaista merkintätapaa.

Roomalaisilla oli kuukausissaan kolme merkkipäivää, joista päiviä las- kettiin taaksepäin. Ensimmäinen merkkipäivä oli kuukauden aloituspäivä, jonka nimenä oli Kalendae. (Tästä on peräisin mm. kalenteri-sanamme.) Toinen merkkipäivä oli kuukauden viidentenä tai seitsemäntenä, ja se oli nimeltään Nonae. Kolmas merkkipäivä oli kuukauden puolivälissä, ja se oli nimeltään Idus.

Merkkipäivät olivat aluksi sidottuja kuun vaiheisiin. Kalendae merkitsi kuun sirpin ilmestymistä uudenkuun jälkeen, Nonae oli puolikuun hetki ja Idus täysikuun hetki. Päivämärä pystyttiin katsomaan kuun muodosta. Myöhemmin roomalaisten kuukaudet irtosivat todellisesta kuun kierrosta, mutta merkkipäivät jäivät entisille paikoilleen.

Roomalaiset antoivat kaikille muille päiville numeron, joka kertoi, montako päivää ennen seuraavaa merkkipäivää se sijaitsi (ja roomalaisessa laskutavassahan sekä alku- että loppupäivä laskettiin mukaan lukuun). Kaikki roomalaisen kalenterin päivät näkyvät seuraavan sivun taulukosta.

Niinpä tammikuun toinen päivä oli roomalaisilla "neljäs päivä ennen

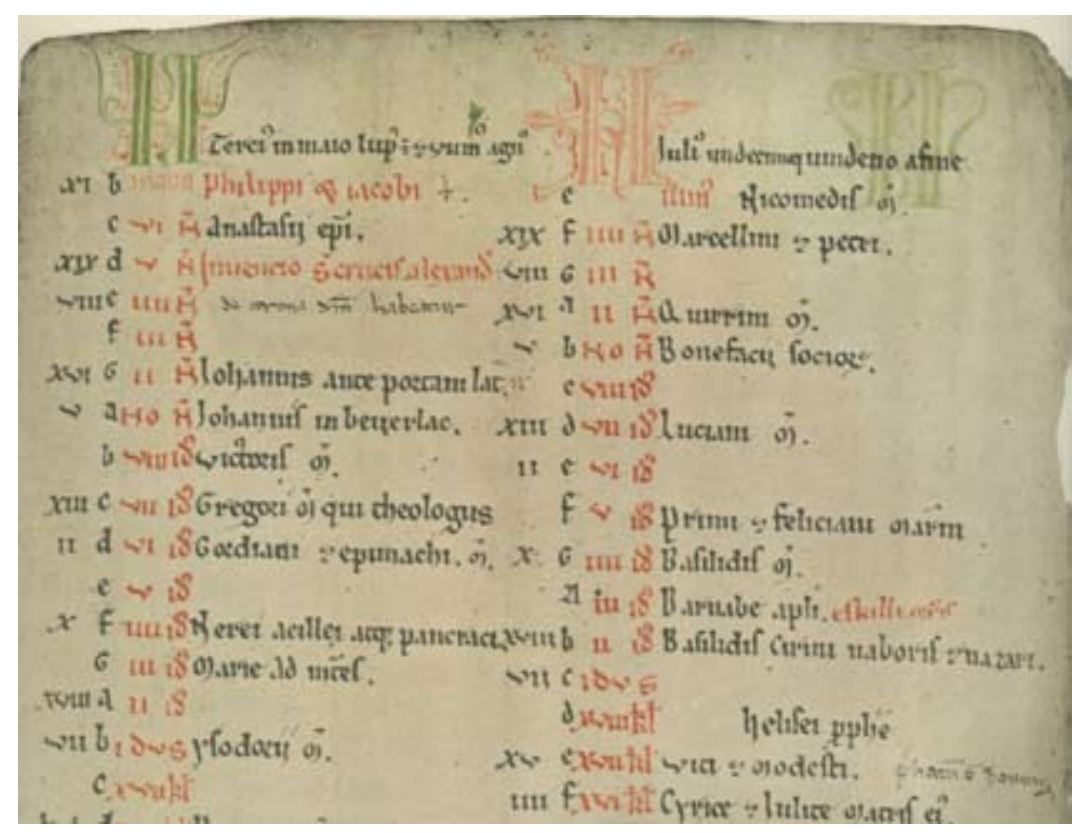

Touko- ja kesäkuun alkua ruotsalaisessa Vallentunan kalenterissa vuodelta 1198 Päivät on merkitty pelkästään roomalaisen tavan mukaan. 


\section{Roomalainen kuukauden- päivien numerointi}

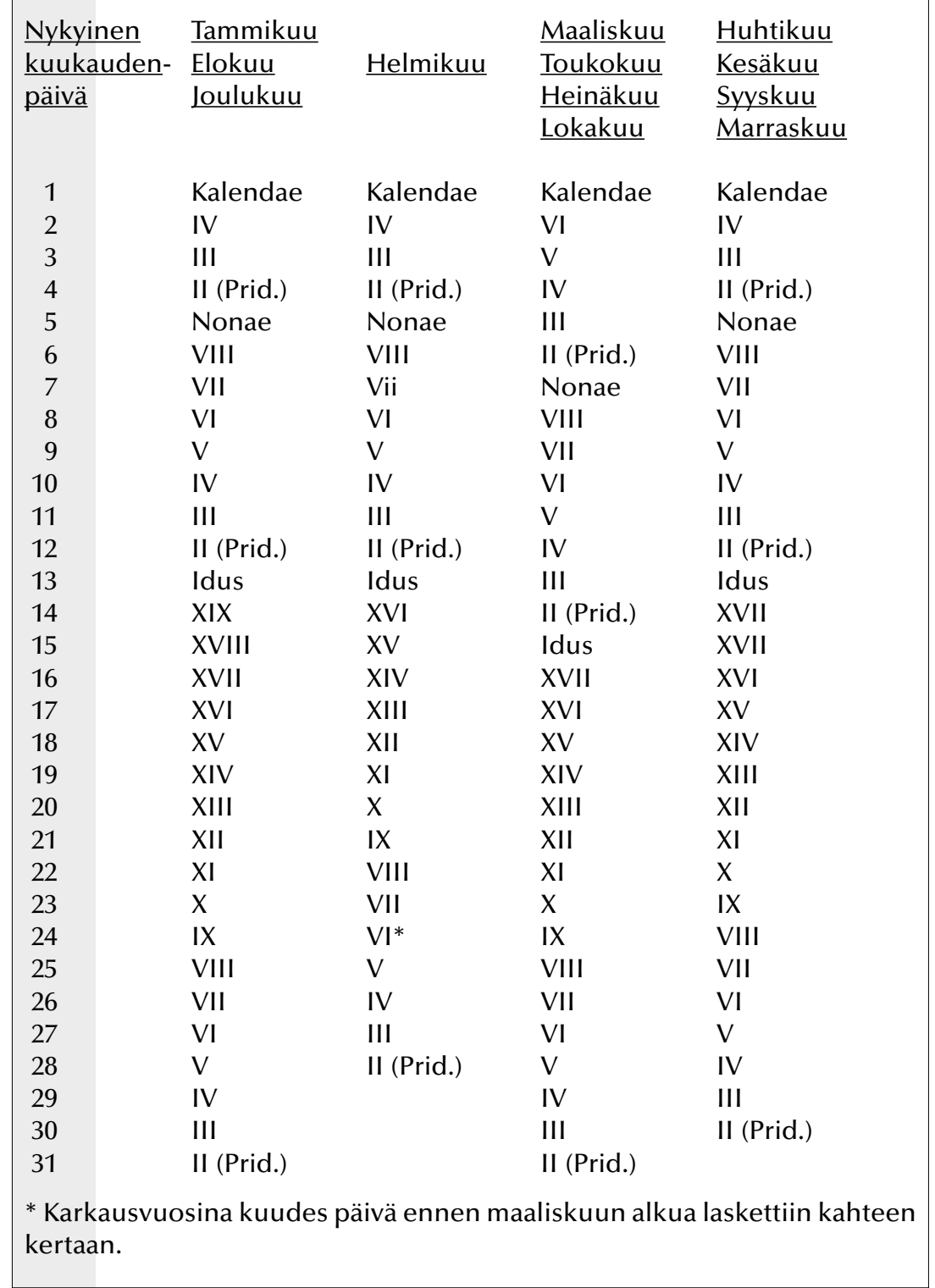

tammikuun Nonaeta", ja helmikuun 24. päivä oli "kuudes päivä ennen maaliskuun Kalendaeta". Karkauspäivällä ei ollut omaa numeroa, vaan se oli "toinen kuudes päivä ennen maaliskuun Kalendaeta".

Viimeiselle päivälle ennen merkkipäivää ei useinkaan käytetty "toinen päivä" -merkintää, vaan sanaa Pridie (= edeltävä), esim. Pridie Nonas Augusti (= 4. elokuuta).

Vaikka roomalaisten valta murtui Euroopassa 400-luvun alussa, roomalainen ajanlasku säilyi vuosisatoja eteenpäin. Juliaaninen kalenteri sinänsä oli voimassa gregoriaanisen kalenterin tuloon asti eli 1500-luvun lopulle. Roomalainen päivienmerkitsemistapa säilyi sekin 1000-luvun puoliväliin asti. Silloin pääsi valtaan nykyinen tapa numeroida päivät juoksevassa järjestyksessä kuukauden alusta alkaen. Esimerkiksi Suomen vanhimmissa kalentereissa 1500 -luvulle asti käytettiin roomalaista päivämerkintää, mutta 1600-luvulla oli jo käytössä nykyinen tapa.

\section{Vuosien numerointi}

Caesarin aikaan laskettiin vuosilukuja senhetkisen hallitsijan valtakauden alusta lähtien tai Rooman perustamisesta lähtien. Esimerkiksi nykyisen ajanlaskumme vuosi 1 merkittiin keisari Augustuksen hallituskauden 26. vuodeksi tai vuodeksi 753 kaupungin perustamisesta lähtien.

Sama käytäntö jatkui seuraavina vuosisatoina. Nykyisen ajanlaskumme vuoden 500 paikkeilla saatettiin laskea vuosia keisari Diocletianuksen hallituskauden alusta parinsadan vuoden takaa.

Dionysius Exiguus -niminen munkki sai 500-luvulla tehtäväkseen pääsiäisen laskemisen tuleville vuosille. Hän ehdotti pääsiäisen määräämiseksi 532-vuotista jaksoa ja totesi, että Jeesuksen oletetusta syntymävuodesta oli kulunut juuri tuo 532 vuotta. Kun Dionysius julkaisi pääsiäislaskunsa seuraaville yhdeksälletoista vuodelle, hän nimesi nämä vuodet sanoilla "Anno Domini Nostri Jesu Christi 532-550" eli meidän Herramme Jeesuksen Kristuksen vuodet 532-550.

Seuraavalla vuosisadalla Englannin kirkko teki päätöksen, että pääsiäisen paikka lasketaan jatkossa Dionysiuksen ehdottamalla tavalla. Historioitsija Beda kirjoitti laajan kirjan Englannin kirkon historiasta, ja saadakseen vuosien merkitsemiseen yhtenäisen linjan hän ryhtyi kirjassaan käyttämään Dionysiuksen vuosilaskutapaa. Beda ulotti saman merkintätavan Jeesuksen syntymää edeltäviin tapahtumiin. Vuotta 1 jKr 
edeltäväksi vuodeksi merkittiin $1 \mathrm{eKr}$.

Kristuksen syntymään perustuva vuosinumerointi levisi kirkkoisien kirjoituksissa Englannista Keski-Eurooppaan. Kaarle Suuri, joka perusti 900-luvulla Länsi-Eurooppaan uuden roomalaisvaltakunnan, otti sen viralliseksi vuosijärjestelmäksi.

Kesti kuitenkin vielä satoja vuosia, ennen kuin Jeesuksen syntymään sidottu laskutapa syrjäytti paikalliset, eri hallitsijoiden hallitusvuosiin perustuvat merkintätavat. Vasta 1600-luvulle tultaessa oli nykyinen vuosijärjestelmä levinnyt koko Eurooppaan.

\section{Mistä viikko sai alkunsa}

Kuukautta lyhempiä ajanjaksoja varten on tarvittu oma aikayksikkö. Ihminen tarvitsee työnsä lomassa silloin tällöin lepopäiviä, jotka voi omistaa esimerkiksi hartaudelle ja jumalien palvomiselle. Eri kulttuureissa on esiintynyt eripituisia "viikkoja" viiden päivän jaksosta kymmenen päivän jaksoon.

Julius Caesarin aikana Roomassa oli vallalla seitsenpäiväinen viikko, jonka päivät olivat saaneet nimensä seitsemän tunnetun planeetan mukaan; tuohon aikaan aurinko ja kuu laskettiin planeettojen joukkoon. Planeetat taas olivat samannimisiä kuin roomalaisten tärkeimmät jumalat.

Sunnuntai oli auringon päivä ja maanantai kuun päivä. Tiistai oli omistettu Marsille, keskiviikko Merkuriukselle, torstai Jupiterille, perjantai Venukselle ja lauantai Saturnukselle. Samat jumalat tai niiden vastineet ovat vieläkin pohjana useimpien länsimaisten kielten viikonpäivien nimissä.

Viikko ei kuitenkaan ollut roomalaisten keksintö, vaan se oli paljon vanhempaa perua. Jo tuhatkunta vuotta ennen ajanlaskumme alkua on babylonialaisissa teksteissä mainintoja, miten kuukauden seitsemäs, neljästoista, kahdeskymmenesensimmäinen ja kahdeskymmeneskahdeksas päivä ovat lepopäiviä. Nämä päivämäärät sattuvat suurin piirtein yhteen kuun vaiheiden (ensimmäisen neljänneksen, täydenkuun, viimeisen neljänneksen ja uudenkuun) kanssa.

Vuoden 600 eKr paikkeilla juutalaiset omaksuivat seitsenpäiväisen viikon. Israelin kansa oli vankeudessa Babyloniassa ja sai sieltä vaikutteita ajanlaskuunsa. Seitsenpäiväinen viikko sopi yhteen Raamatun luomis-
Viikonpäiville saatiin nimet seitsemästä "planeetasta". Entisaikaan planeettojen joukkoon laskettiin myös aurinko ja kuu. (Puupiirros keskiaikaisesta astrologisesta taulusta)

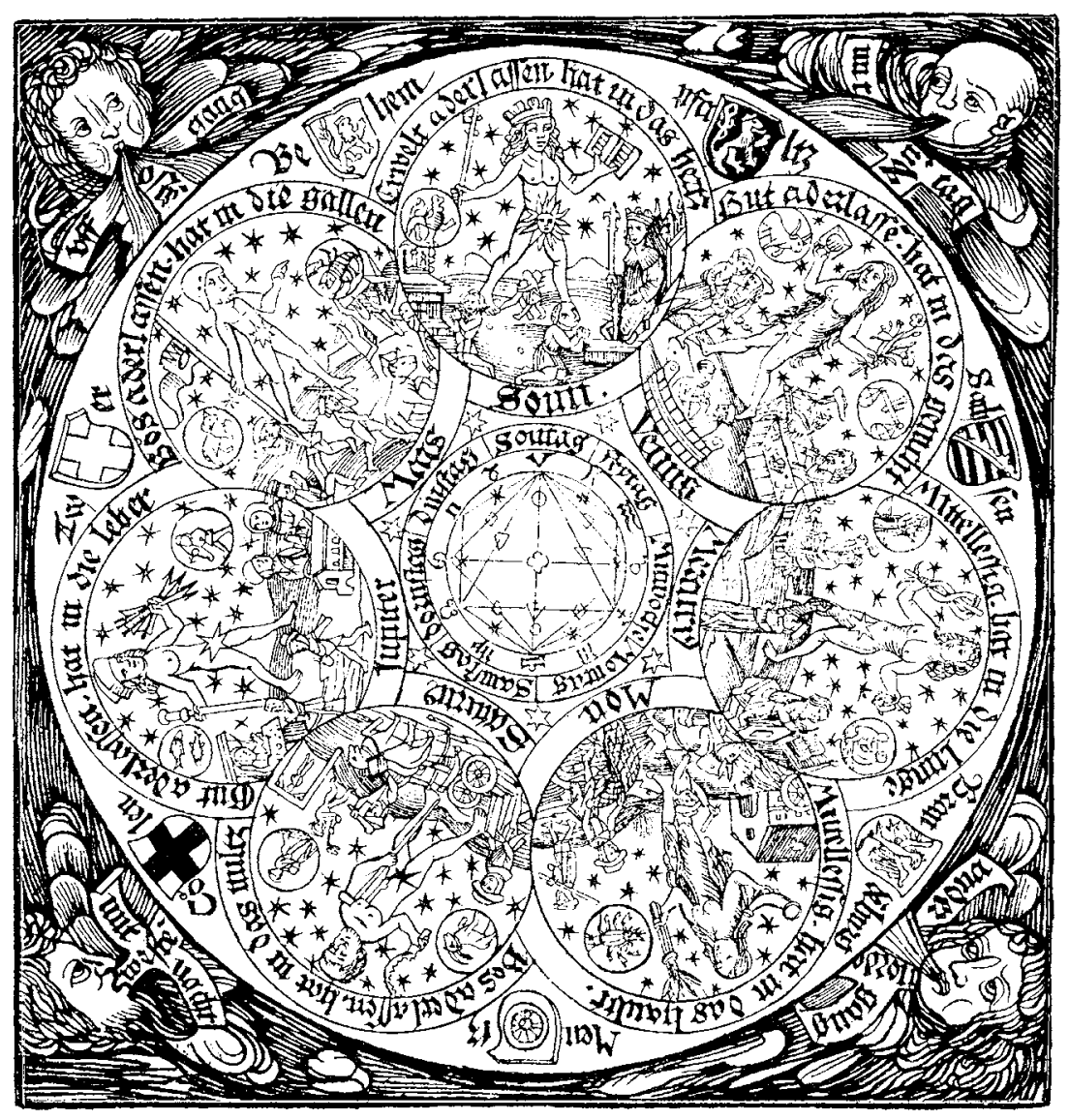

kertomuksen kanssa - tai luomiskertomus kirjoitettiin sopimaan yhteen seitsenpäiväisen viikon kanssa. Oli miten oli, juutalaisilla joka seitsemäs päivä oli omistettu levolle ja rukouksille. Tätä päivää sanottiin sapatiksi; se alkoi perjantaina auringon laskiessa ja päättyi lauantai-illan auringonlaskuun. Muilla päivillä ei ollut muuta nimeä kuin järjestysnumero, ja sunnuntai oli viikon ensimmäinen päivä.

Ajanlaskumme alkuvuosisatoina kristityt omaksuivat juutalaisten jatkuvasti toistuvan viikon ja hyväksyivät vähitellen, tosin vastahakoisesti, 
päiville niiden roomalaiset, pakanalliset nimet. Viralliseksi ajanlaskutavaksi viikko tuli keisari Konstantinuksen aikaan vuoden 320 paikkeilla. Keisari määräsi viikon ensimmäisen päivän, auringon päivän, erityiseksi Herran päiväksi ja lepopäiväksi.

Roomalaisen ajanlaskun mukana myös viikko vakiintui koko läntiseen maailmaan.

\section{Suomalaisten vanha ajanlasku}

Vanhoille suomalaisille kuukausi merkitsi todellista kuun vaiheiden kiertoa eikä nykyistä keinotekoista 30 tai 31 päivän jaksoa. Kuukauden pituutena he eivät kuitenkaan pitäneet todellista 29 1/2 päivää, vaan noin 28 päivää. Tämä on helposti ymmärrettävää, jos ajattelee miten kuun vaiheet oikeastaan näkyvät.

Koettakaapa jonakin selkeänä aikana seurata kuun käyttäytymistä. Helpointa se on jos kaupungin valot eivät ole häiritsemässä - eihän esi-
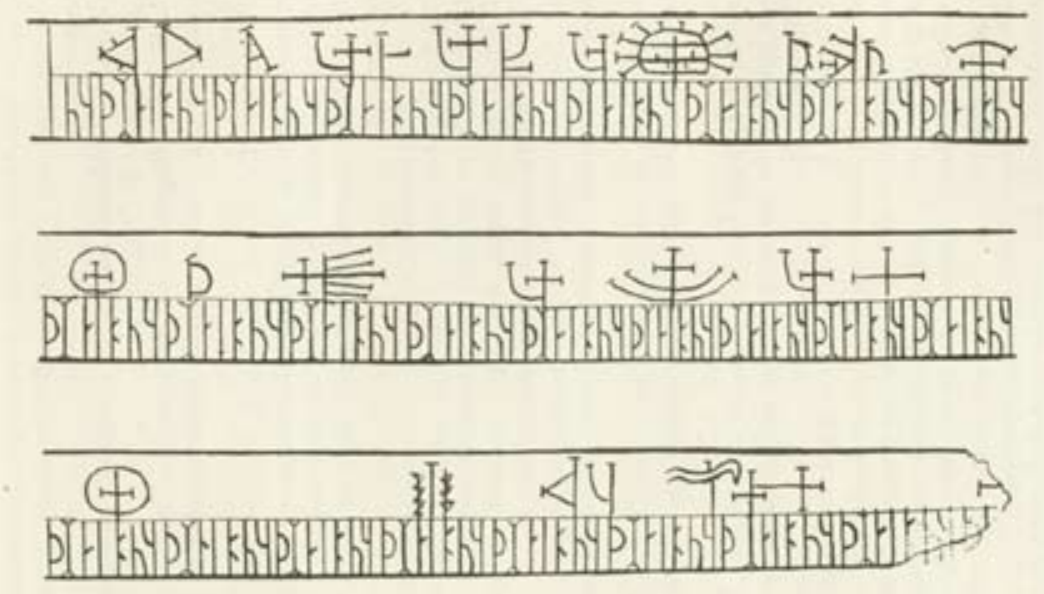

Riimusauva toimitti kalenterin virkaa, ennen kuin paperille painettu almanakka yleistyi. Sauvan merkeistä pystyi seuraamaan ajan kulkua ja laskemaan pyhäpäivien paikat. Kuvassa vanhimman tunnetun suomalaisen riimusauvan merkkejä. Sauva on noin vuodelta 1566, ja se on Pariisissa Sainte-Genevièven kirjastossa. (Kuva Suomen Museo -lehdestä 1952) isillämmekään ollut juuri pärettä vahvempia valaisimia.

Sitä mitä nykyään sanomme uudeksikuuksi, eli kuun ja auringon kohtaamista, ei luonnossa pysty näkemään, koska auringon loisto peittää kokonaan kuun heikon valon. Aivan ohut kuun sirppi ilmestyy auringon vasemmalle puolelle noin vuorokauden kuluttua uudenkuun hetkestä, ja tämä merkitsi vanhoina aikoina kuukauden alkua.

Noin seitsemässä päivässä kuu kasvaa ensimmäiseksi neljännekseksi, jälleen seitsemässä päivässä täydeksi kuuksi, taas seitsemässä päivässä pienenee viimeiseksi neljännekseksi, ja kun viimeiset seitsemän päivää ovat kuluneet, ohut kuun sirppi katoaa auringon hehkuun.

Kuukauden päätyttyä oli vuorokausi tai kaksi tyhjää aikaa, joka ei kuulunut mihinkään kuukauteen, ennen kuin ohut kuunsirppi auringon toisella puolella taas kertoi seuraavan kuukauden alkavan.

Ennen kuin eurooppalainen kirkollinen kalenteri vakiintui Suomeen keskiajalla, oli viikkoihin perustuva ajanlasku kuitenkin jo irronnut oikeista kuun vaiheista. Seitsenpäiväisiä viikkoja laskettiin peräkkäin eikä enää jätetty uudenkuun aikaan tyhjiä päiviä.

Viikkolaskujärjestelmässä vuosi jakautui kahteen puolikkaaseen, talveen ja kesään. Ensimmäinen talvipäivä oli Calixtuksen päivänä 14 . lokakuuta ja ensimmäinen kesäpäivä Tiburtiuksen päivänä huhtikuun 14:ntenä. Näiden päivien välissä oli sydäntalvi tammikuussa ja keskikesä heinäkuussa. Kustakin määräpäivästä seuraavaan oli tasan 13 viikkoa, joten vuoden pituudeksi tuli 364 vuorokautta. Vuodenvaihteessa kuitenkin otettiin ilmeisesti yksi päivä lisää, jolloin päästiin 365-päiväiseen vuoteen eli hyvin lähelle oikeaa lukua.

Vuoden vaihtuminen ei vanhoilla suomalaisilla alkuaan tapahtunut nykyisellä paikallaan. Kustaa Vilkuna arvelee kirjassaan Vuotuinen ajantieto, että suomalainen vuosi vaihtui syksyllä. Kun kaikki syystyöt oli pelloilla tehty mutta metsästyskausi ei ollut vielä alkanut, silloin oli sopiva aika viettää "jakoaikaa", vanhan vuoden loppua ja uuden alkua.

Myöhemmin, viikkolaskujärjestelmässä, vuosi vaihtui sydäntalven aikaan.

Sodankyläläinen tähtitieteilijä Johannes Kultima arvelee, että vanhat suomalaiset eivät sijoittaneet vuoden alkua mihinkään: "Olen sitä mieltä, että vuosi on ollut vain ajanjakso, esim. keväästä seuraavaan kevääseen, syksystä seuraavaan syksyyn. Mikäli vuosi aloitettiin jostakin hetkestä, luonnollisin alku on kevät; olihan myös silloin suomalaisilla 
käytössä kuu- ja aurinkovuoden tasauskuukausi, ns. vaahtokuu (Vilkuna); samaten puhuttiin keväällä ja nimenomaan keväällä 'vuodentulosta' erilaisten ennusteiden yhteydessä."

On muuten mielenkiintoista, että suomalaisten sydäntalvi ja keskikesä eivät satu tähtitieteellisten talvi- ja kesäpäivänseisausten aikoihin, jolloin siis yö tai päivä ovat pisimmillään, vaan kolmisen viikkoa myöhemmin. Pitkäaikaiset säätilastot näyttävät osoittavan, että vuoden kylmin ja lämpimin aika sattuvatkin hyvin lähelle näitä suomalaisten merkkipäiviä. Juhannuksen tienoille sattuvan kesäpäivänseisauksen jälkeen sää vielä vähän lämpenee ennen kuin heinäkuun loppupuolella alkaa kylmetä. Vastaavasti talven kylmin aika on keskimäärin tammikuun puolivälissä.

Vanhaa suomalaista ajanlaskua käytettiin meillä yleisesti vielä 1600luvulla. Jo paljon aikaisemmin, 1200-luvulla, oli kristinuskon mukana maahamme alkanut tunkeutua uudenlainen ajanlaskutapa, länsimainen kalenteri, joka sitten syrjäytti paikallisen ajanlaskun.

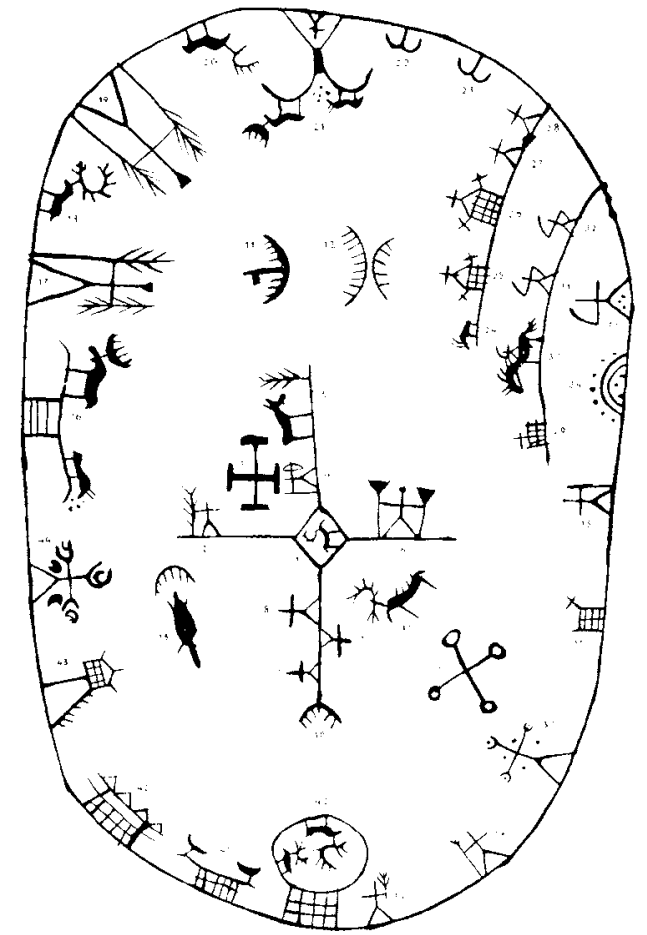

Saamelaisessa rummussa on kuvattuna tähtitaivasta. Saamelaisten ajanlasku muistutt vanhaa suomalaista ajanlaskua, mutta rakentui pääasiassa poronhoidon rytmin mukaan. Riimukalenteria käytettiin pitkään ajanluvun välineenä, vaikka Ruotsin valtio on 1700 -luvulta alkaen painattanut saamenkielisiä almanakkoja

\section{Gregoriaaninen kalenteri}

Julius Caesarin säätämä ajanlasku oli voimassa yli 1500 vuotta. Sen syrjäyttäminen johtui siitä, että se ei ollut tarpeeksi tarkka. Juliaanisen kalenterin vuosi oli keskimäärin tasan 365 1/4 vuorokauden pituinen. Mutta tarkemmat mittaukset antoivat tulokseksi, että todellinen vuoden pituus on noin 11 minuuttia tätä pienempi.

Yksitoista minuuttia ei tunnu kovin suurelta virheeltä, mutta kun minuutteja kertyy vuodesta toiseen ja vuosisadasta toiseen, virhe kasvaa. Kun tultiin 1500-luvulle, olivat vuodenajat jo toistakymmentä vuorokautta värässä paikassa.

Mutta mikä oli katolisen kirkon mielestä vielä pahempi asia, myös pääsiäinen oli väärässä paikassa. Pääsiäisen paikka laskettiin kevätpäiväntasauksesta, ja vuonna 325 pidetty Nikean kirkolliskokous oli määrännyt kevätpäiväntasauksen ajankohdaksi 21. maaliskuuta, niin kuin se siihen aikaan sattui olemaan.

Nyt runsaat tuhat vuotta myöhemmin kevätpäiväntasaus oli ajautunut jo maaliskuun 11. päivään. Se täytyi saada takaisin oikealle kohdalleen.

Ajanlaskun korjaajaksi tuli paavi Gregorius XIII, joka 1580-luvulla otti

Paavi Gregorius XIII otti käyttöön nykyisen kalenterin vuonna 1582

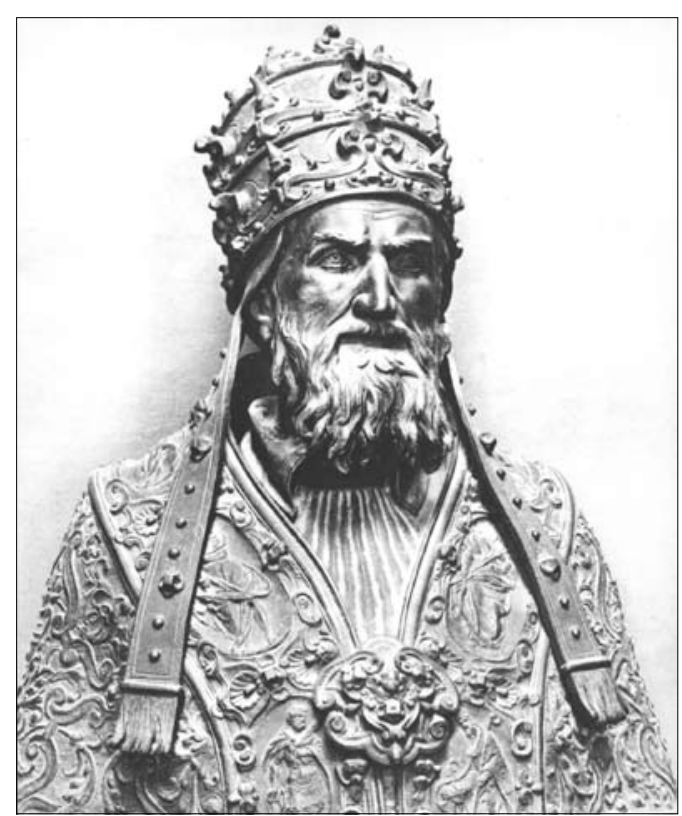


käyttöön uuden kalenterin. Sitä sanotaan gregoriaaniseksi kalenteriksi, ja se on käytössä Suomessakin vielä tänä päivänä.

Gregorius teki juliaaniseen ajanlaskuun muutamia muutoksia. Ensinnäkin kevätpäiväntasaus ja vuodenajat saatettiin kohdalleen jättämällä ajanlaskusta pois kymmenen päivää. Tämä tapahtui syksyllä 1582, jolloin lokakuun 4. päivää seurasi suoraan lokakuun 15. päivä.

Vuoden oikea pituus otettiin huomioon muuttamalla karkaussääntöä. Juliaanisessa kalenterissa oli poikkeuksetta joka neljäs vuosi ollut karkausvuosi, mutta nyt gregoriaanisessa kalenterissa tehtiin poikkeuksia täysien vuosisatojen kohdalla. Nämä poikkeukset takaavat sen, että vuodenajat, kevätpäiväntasaus ja siis myös pääsiäinen pysyvät oikeilla paikoillaan tuhansia vuosia eteenpäin.

Uuden karkaussäännön mukaan täysistä sataluvuista ovat karkausvuo-

Saksalaisen Johannes von Gmundenin kalenteri 1400-luvulta. Aurinko siirtyy eläinradan merkkeihin kunkin kuun 10. päivän kohdalla, koska kalenteri on ilmestynyt ennen kuin paavi Gregoriuksen uudistus otettiin käyttöön.
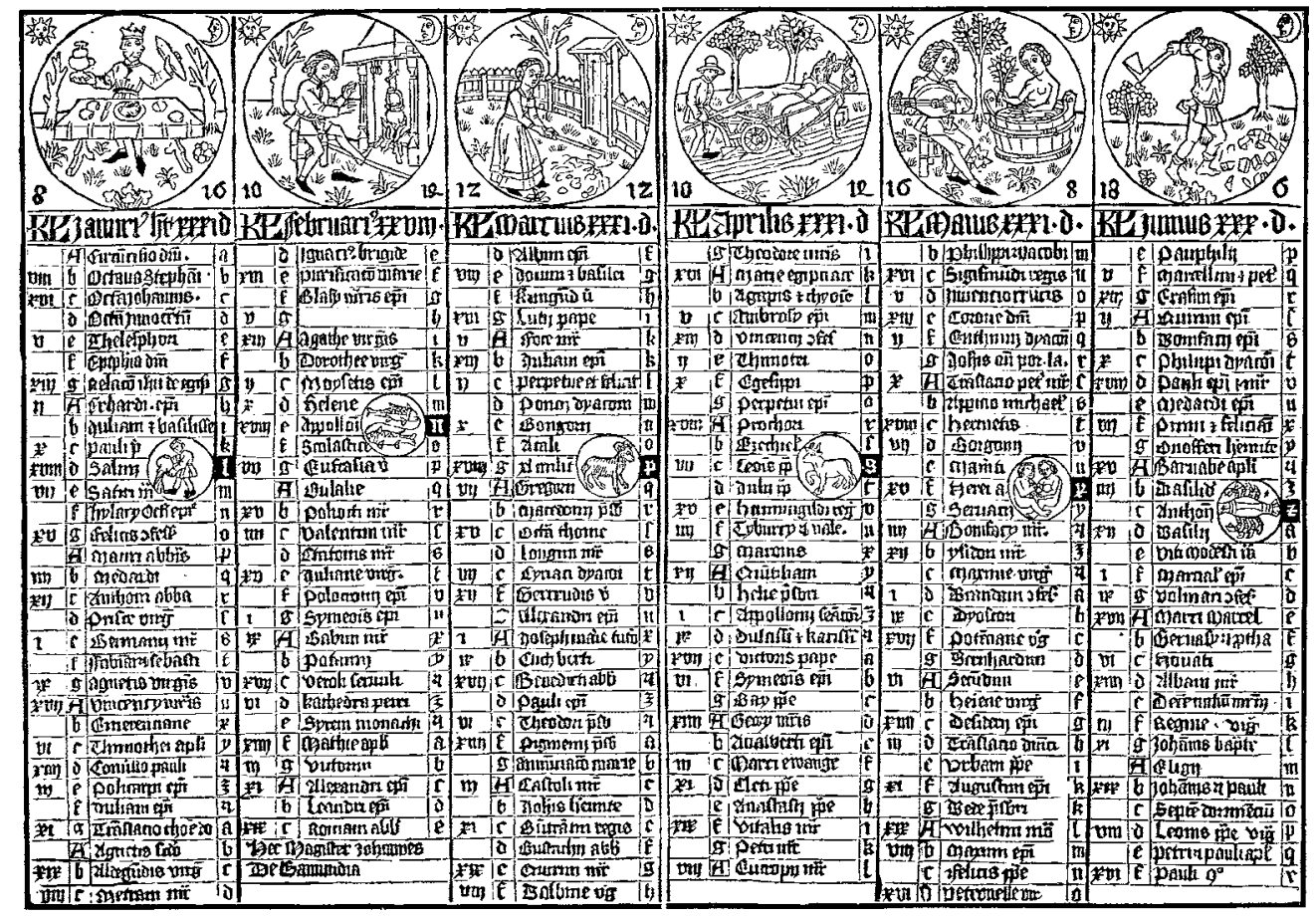

sia vain ne, jotka ovat jaollisia 400:lla. Siten vuosi 1900 ei ollut karkausvuosi, 2000 oli karkausvuosi, mutta 2100 taas ei ole.

Tähän seikkaan perustuu muuten se digitaalikellojen mainos, jonka mukaan näiden kellojen päivyrit on ohjelmoitu näyttämään oikein vuoteen 2100 asti. Kelloissa on voitu ottaa huomioon, että joka neljäs vuosi on karkausvuosi, ja ensimmäinen poikkeus karkausvuosien tasaiseen sarjaan tulee vasta vuonna 2100. Se on taas neljäs vuosi, mutta ei karkausvuosi. Eri asia on, kuinka moni nykyisistä kelloista toimii noin kauan!

Gregoriaaninen kalenteri otettiin katolisissa maissa käyttöön tietysti heti, koska paavi näin määräsi. Katolisia maita olivat esimerkiksi Italia ja Espanja. Sen sijaan Pohjois-Euroopan luterilaisissa maissa ei voitu ajatellakaan, että katolisen kirkon päämiehen märäystä olisi ruvettu noudattamaan.

Pohjois-Euroopassa, myös Ruotsissa, elettiin siis edelleenkin juliaanisen kalenterin mukaan. Suomessa vanhat kansalliset ajanlaskutavat olivat juuri jäämässä syrjään. Vuoden alku siirrettiin meillä nykyiselle

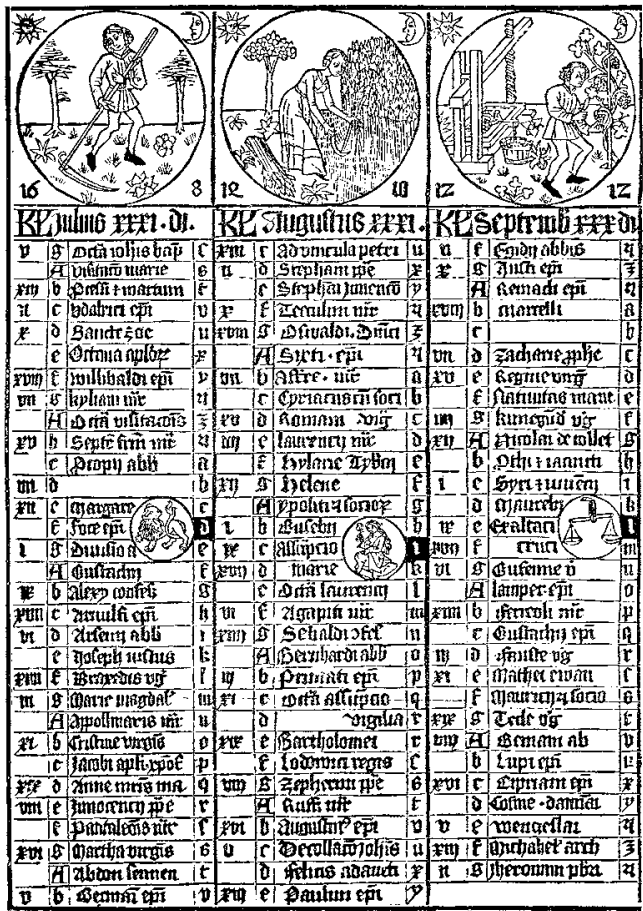

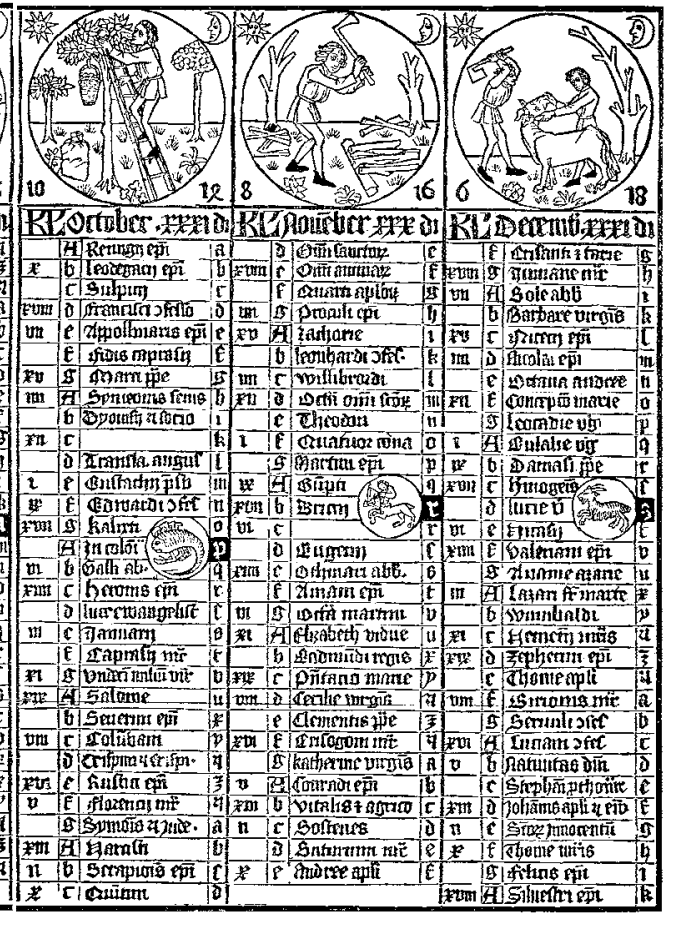

43 
paikalleen 1500-luvun puolivälissä, ja 1600-luvulla juliaaninen kalenteri vakiintui laajemmin meillekin.

\section{Parannettu kalenteri}

Kun luterilaiset maat eivät voineet ottaa gregoriaanista kalenteria käyttöön sellaisenaan, mutta uuden kalenterin edut vanhaan verrattuna kuitenkin olivat selvät, keksittiin 1600-luvun lopulla Saksassa pelastus. Kehitettiin ns. parannettu kalenteri. Sen karkaussääntö oli aivan sama kuin gregoriaanisen, mutta pääsiäinen laskettiin tähtitieteen avulla todellisen kevättasaushetken ja todellisen täysikuun mukaan.

Parannettu kalenteri otettiin Saksassa käyttöön vuonna 1700, jolloin gregoriaanisen kalenterin uutta karkaussääntöä ensimmäisen kerran sovellettiin. Niinpä Saksassa elettiin samassa tahdissa katolisten maiden kanssa.

Toisin kävi kuitenkin Ruotsissa. Täällä tehtiin sellainen omalaatuinen ratkaisu, että vuonna 1700 jätettiin karkauspäivä pitämättä, jotta saataisiin ero "uuteen lukuun" eli gregoriaaniseen kalenteriin pysymään ennallaan kymmenenä päivänä. Varsinaisessa juliaanisessa kalenterissa karkauspäivä pidettiin, ja siksi ruotsalaisten ajanlasku erosi juliaanisesta yhdellä päivällä.

Kun ensimmäinen suomenkielinen almanakka ilmestyi 1705, sen ajanlasku oli juuri omalaatuinen ruotsalainen. Oman ajanlaskun mielettömyys huomattiin tietysti pian, ja 1712 siitä palattiin takaisin juliaaniseen. Tuona vuonna helmikuuhun liitettiin peräti kaksi karkauspäivää, joten helmikuun pituus oli 30 päivää.

Juliaaninen kalenteri ei kuitenkaan ole yhtä tarkka ajanlaskujärjestelmä kuin gregoriaaninen tai parannettu kalenteri, ja siksi meilläkin siitä luovuttiin nelisenkymmentä vuotta myöhemmin. Ruotsi-Suomi siirtyi parannettuun kalenteriin 1753 jättämällä helmikuun lopusta pois 11 päivää. Sinä vuonna helmikuun pituus oli vain 17 päivää.

Ruotsi otti vihdoin täydellisen gregoriaanisen kalenterin käyttöön vuosina 1823 ja 1844 annetuilla kuninkaallisilla julistuksilla. Mutta Suomi oli tällöin jo liitetty Venäjään, eikä muutosten teko käynytkään automaattisesti Ruotsin mallin mukaan. Suomi eli edelleen parannetun kalenterinsa mukaan, ainoana maana maailmassa.

Koska parannetun kalenterin karkaussääntö oli sama kuin gregoriaa-

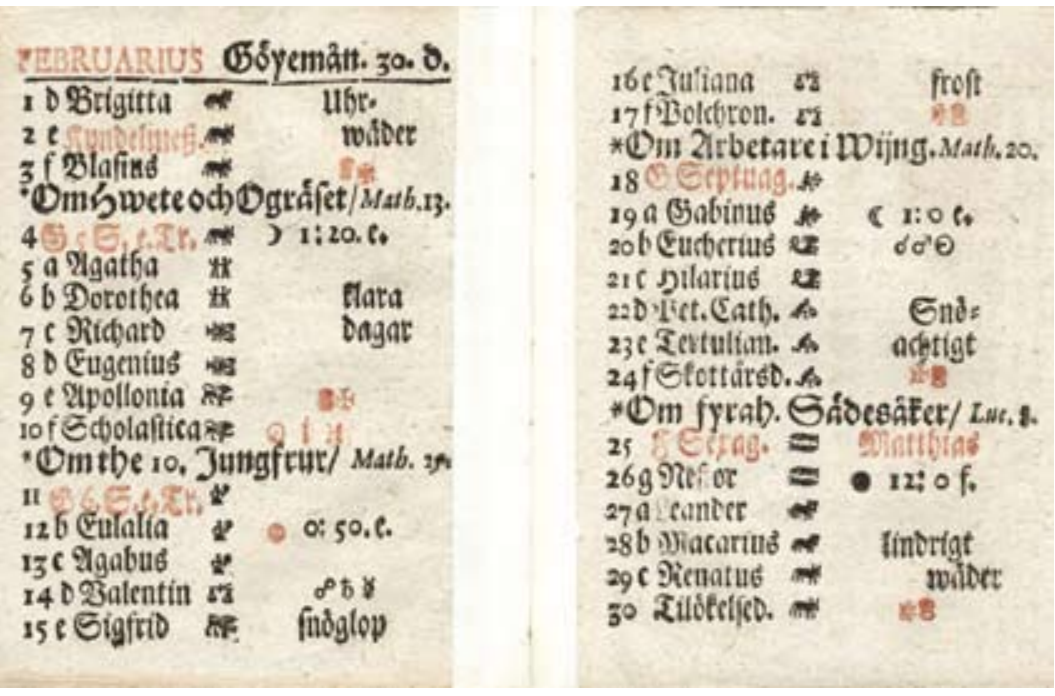

Suomalaisessa kalenterissa oli helmikuussa 1712 kokonaista 30 päivää, kun vuoteen liitettiin poikkeuksellisesti kaksi karkauspäivää.

nisen, elettiin meillä yleensä samassa tahdissa muun Euroopan kanssa (mutta eri tahdissa emämaan Venäjän kanssa, jossa edelleen oli voimassa juliaaninen kalenteri). Poikkeuksia tuli vain pääsiäisten kohdalla. Vuosina 1818, 1825, 1829 ja 1845 parannetun kalenterin pääsiäinen sattui eri viikonlopulle kuin gregoriaaninen. Kahtena keskimmäisenä vuotena pääsiäisen paikka oli kuitenkin sattumalta sama kuin juliaanisessa kalenterissa, mutta kahtena muuna vuonna ei. Vuonna 1818 sekä Suomessa että Ruotsissa juhlittiin pääsiäistä eri sunnuntaina kuin muualla, mutta 1845 Suomi jäi ypöyksin parannetun pääsiäisensä kanssa. Meillä päsiäinen oli maaliskuun 30. päivänä. Länsi-Euroopassa pääsiäinen oli ollut viikkoa aikaisemmin, ja Venäjällä se oli vasta neljä viikkoa myöhemmin.

Tapaus herätti ulkomaillakin huomiota. Seuraavan kerran vastaavanlainen tapaus olisi sattunut 1869. Tällöin meilläkin jo oltiin valmiita luopumaan parannetusta kalenterista. Helsingin yliopisto teki ehdotuksen senaatille ja senaatti keisarille, joka sitten hyväksyi ehdotuksen. Keisarillisella julistuksella Suomi otti käyttöön täydellisen gregoriaanisen kalenterin vuoden 1869 alusta. Emämaassa Venäjällä siirryttiin "vanhasta luvusta" "uuteen lukuun" vasta vallankumouksen jälkeen 1921. 


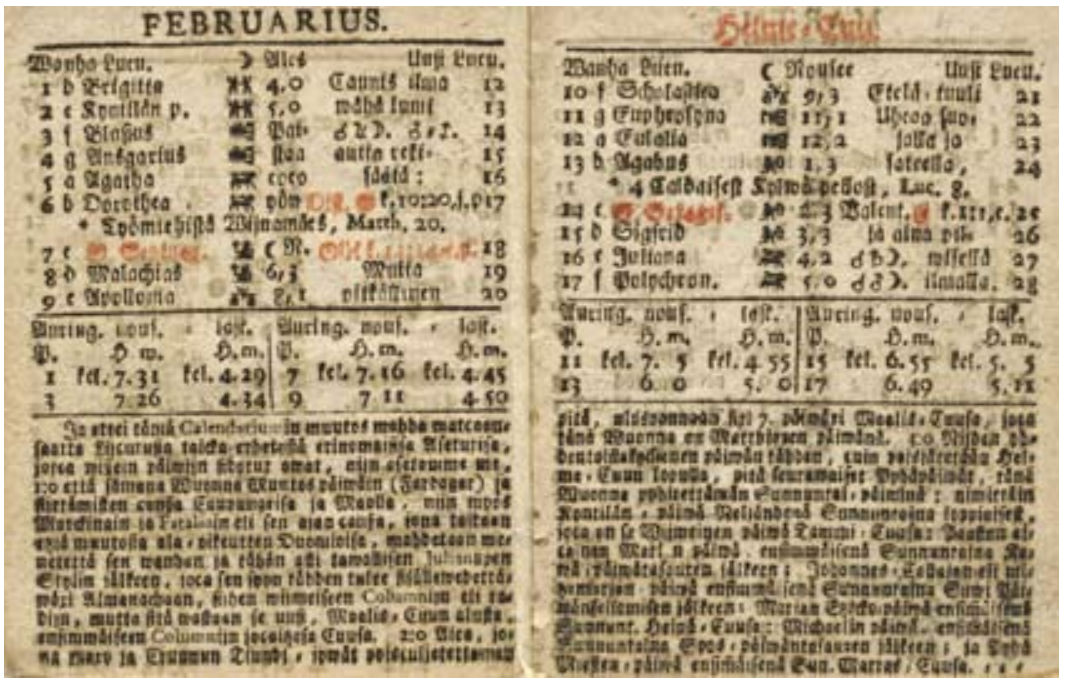

Suomessa siirryttiin "parannettuun kalenteriin" vuonna 1753, jolloin helmikuu oli vain 17 päivän mittainen.

\section{Viikon alku siirtyy maanantaihin}

Seitsenpäiväinen viikko on ollut ajanlaskumme vanhin samanlaisena pysynyt ajanjakso, sillä jo yli 2500 vuoden ajan viikonpäivät ovat toistuneet katkeamatta seitsemän päivän jaksossaan aina uudelleen ja uudelleen. Edes kalenteriuudistukset eivät ole vaikuttaneet viikon kulkuun. Vaikka ajasta on otettu pois päiviä tai lisäilty päiviä, viikonpäivien järjestys on katkojen yli pysynyt samana. Niinpä gregoriaanisen kalenterin syntyessä torstaita lokakuun 4. päivää 1582 seurasi perjantai lokakuun 15. päivä. Tai Suomen siirtyessä gregoriaaniseen kalenteriin vuonna 1753 seurasi keskiviikkoa helmikuun 17. päivää torstai maaliskuun 1. päivä.

Viikon kulkuun kajottiin vasta 1970-luvun alussa, ja silloinkin muutettiin vain viikon aloituspäivää. Vuoden 1970 paikkeilla tehtiin aikaasioissa useita pikku muutoksia, joita ei suuremmin rummutettu, vaan ne levisivät kalentereissa ja arkisessa aikakäytännössä vähitellen ihmisten tietoon. Puhumme seuraavassa luvussa kokonaisen uuden ajan, koordinoidun yleisajan ja sen mukana karkaussekuntien käyttöönotosta.

Muutoksia tapahtui myös viikon määritelmässä. Kansainvälinen kauppa oli jatkuvasti vilkastunut, aikatauluja ruvettiin pitämään tietokoneil- la, ja siksi viikotkin oli numeroitava. Olihan helppoa sanoa, että tavara toimitetaan viikolla 26 , kunhan kaikkien maiden viikkonumerointi tapahtuu samalla tavalla.

Kansainvälinen standardisoimisliitto ISO hyväksyi viikolle ja viikkonumeroinnille uudet standardit, jotka Helsingin yliopisto päätti ottaa käyttöön suomalaisissa kalentereissa vuoden 1973 alussa. Viikko tarkoittaa aina seitsemän päivän ajanjaksoa (kun aikaisemmin vuosi oli saattanut alkaa vaikkapa kaksi- tai viisipäiväisellä "viikolla"). Viikon ensimmäinen päivä on aina maanantai.

Viikkonumeroiden laskeminen aloitetaan vuoden alusta. Jos vuodenvaihde katkaisee viikon, annetaan koko viikolle vanhan tai uuden vuoden viikkonumero sen mukaan, kumpaan vuoteen kuuluu enemmistö viikon päivistä. Jos uuden vuoden puolella on viikon päivistä 4, 5 tai 6 , saa viikko numeron 1 . Jos uuden vuoden puolella on viikon päivistä vain 3, 2 tai 1, annetaan viikolle vanhan vuoden viikkonumero 52 tai 53 .

Yksinkertaiseksi säännöksi muutettuna sopimus tarkoittaa, että viikko 1 on se viikko, johon kuuluu vuoden ensimmäinen torstaipäivä.

Seuraavat viikot saavat sitten järjestysnumeron 2, 3 jne. Vuodessa on tavallisesti 52 viikkoa. Keskimäärin noin viiden vuoden välein on vuoden lopussa viikko 53. Tämä numero saadaan silloin, kun tavallinen vuosi alkaa torstailla (jolloin myös vuoden viimeinen päivä on torstai) tai karkausvuosi alkaa keskiviikolla tai torstailla. Seuraavat 53-viikkoiset vuodet ovat 2015, 2020 ja 2026.

Kaikissa maissa ei viikkonumerointi toimi kansainvälisen standardin mukaan. Esimerkiksi Yhdysvallat ei ole liittynyt sopimukseen, ja siksi sikäläisissä kalentereissa viikko yleensä alkaa sunnuntaipäivällä. Viikkonumerointia ei amerikkalaisissa kalentereissa juuri näe. Jos viikkonumeroita esiintyy esimerkiksi Yhdysvalloissa tehdyissä tietokoneohjelmissa, on numerointi usein erilainen kuin meillä. Vuosi saattaa aina alkaa viikolla 1. Jos meidän uudenvuodenpäivämme onkin viikolla 52 tai 53 , poikkeavat koko vuoden viikkonumerot toisistaan.

\section{Viikonpäivien nimet}

Puhuimme aikaisemmin tässä luvussa latinalaisista päivien nimistä. Meidänkin sunnuntai-sanamme on peräisin aurinkoa merkitsevästä sanasta (esim. saksaksi Sonntag) ja maanantai on peräisin kuusta (esim. ruotsin 
måndag). Roomalaisten "Marsin päivän" nimessä on sodan jumala Mars korvautunut yhtä sotaisalla pohjoisemmalla Tiw-jumalalla (esim. ruotsin tisdag). Keskiviikko oli Suomessa viikon keskimmäinen päivä silloin kun tämä nimi vakiintui; nykyäänhän keskimmäinen päivä on torstai. Keskiviikko on kuitenkin edelleen hyvin sopiva nimi 5-päiväisen työviikon keskimmäiselle päivälle.

Roomalaisten Jupiterin päivä on meillä torstai, kun ylijumala Juppiter on korvattu pohjoismaisella Tor-jumalalla (esim. ruotsin torsdag). Perjantai oli roomalaisilla Venuksen päivä, kun pohjoismaissa Venus on saanut väistyä Freija-jumalattaren tieltä (esim. ruotsin fredag). Lauantai oli Roomassa Saturnuksen päivä ja juutalaisilla sapatti, mutta pohjoismaissa se on ollut "kylpypäivä", esimerkiksi ruotsissa lördag, josta on tullut meidän lauantaimme.

Venäjän kielessä on jo vanhastaan pidetty maanantaita viikon ensimmäisenä päivänä, sillä tiistaita tarkoittava sana on "toinen", torstaita tarkoittava "neljäs" ja perjantaita "viides". Sama pätee viron kielessä: maanantai on esmaspäev, tiistai teisipäev ja torstai neljapäev.

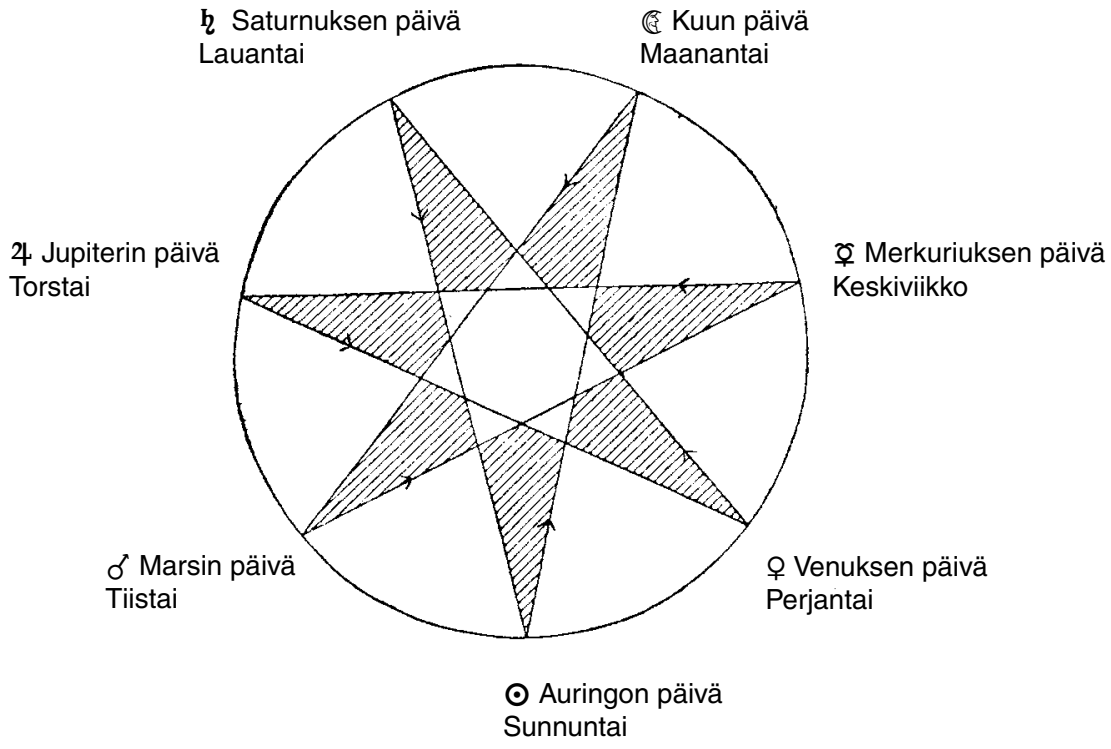

Keskiaikainen astrologinen piirros viikonpäivistä ja niitä hallitsevista planeetoista.

\section{Perjantai ja 13. päivä}

Yksi meidän gregoriaanisen kalenterimme kiintoisia pikku merkillisyyksiä on se seikka, että kuukauden 13. päivä on todennäköisemmin perjantai kuin mikään muu viikonpäivä. Tämä nähdään, jos lasketaan eri kuukaudenpäiville sattuvat viikonpäivät täydessä 400 vuoden jaksossa.

Gregoriaanisen kalenterin vuodet toistuvat viikonpäivien suhteen täsmälleen samanlaisina 400 vuoden välein. Neljäsataavuotisessa jaksossa on 4800 kuukautta, 20871 viikkoa ja 146097 päivää. Koko jaksossa on tietysti täsmälleen sama määrä eri viikonpäiviä, 20871 kutakin. Mutta

\section{Viikonlopun määritelmä}

asten huoltosopimuksiin merkitään usein, että lapset ovat toisen osa- puolen hoidossa esimerkiksi kuukauden ensimmäisenä ja kolmantena viikonloppuna. Yliopiston almanakkatoimistosta on usein kysytty, miten kuukauden ensimmäinen viikonloppu määritellään. Erästä riitatapausta varten almanakkatoimisto antoi asiasta kirjallisen lausunnon, jossa todettiin, että Suomi otti vuoden 1973 alusta käyttöön Kansainvälisen standardisoimisjärjestön ISO:n mukaisen viikon määritelmän. Sen mukaan viikon ensimmäinen päivä on aina maanantai.

"Standardi ei anna määritelmää sille, mikä on kuukauden ensimmäinen viikonloppu. Jos kuukausi alkaa maanantailla, tiistailla, keskiviikolla, torstailla tai perjantailla, asia on tietysti selvä. Mutta jos kuukausi alkaa lauantailla tai ainakin silloin jos kuukausi alkaa sunnuntailla, termi 'kuukauden ensimmäinen viikonloppu' ei ole yksikäsitteinen. Siksi sopimuksissa yms. ei tulisi mielestämme koskaan käyttää sanontoja 'kuukauden 1., 2. jne viikonloppu'.

Almanakkatoimisto suosittelee, että sopimuksissa käytetään sanontoja 'parillisten viikkojen viikonloppu' ja 'parittomien viikkojen viikonloppu'. Viikkonumerot on ISO:n määritelmän mukaan Suomessa yksikäsitteisesti määrätty ja ne on myös merkitty lähes kaikkiin maamme kalentereihin.

Esimerkiksi eräässä huoltosopimuksessa määritellään, että lapset ovat toisen osapuolen hoidossa 'parillisten viikkojen viikonloppuina perjantaista klo 15:stä sunnuntaihin klo 15:een', ja tämän yksiselitteisen määritelmän ansiosta tapaamiset ovat sujuneet täsmällisesti ja riidoitta."

Jos halutaan joka toisen viikonlopun rytmin menevän tasaisesti yli myös niissä vuodenvaihteissa, joissa vuodessa on mukana viikko 53, täytyy sopimukseen lisätä vielä yksi pykälä, joka vaihtaa parillisten ja parittomien viikkojen tapaamisoikeuden tällaisten vuodenvaihteiden jälkeen. 
viikonpäivät eivät ole aivan tasan jakautuneet eri kuukaudenpäiville.

Oheisesta taulukosta voimme nähdä, että 13. päivä on useimmin perjantai. Neljässäsadassa vuodessa sattuu 13. päivä perjantaille 688 kertaa, keskiviikolle tai sunnuntaille 687 kertaa, mutta torstaille tai lauantaille vain 684 kertaa.

Vastaavasti esimerkiksi 31. päivä on useimmin torstai ja 1. päivä on useimmin sunnuntai. Erot ovat niin pieniä, että niillä ei ole käytännön merkitystä.

\section{Milloin vuosituhat vaihtui}

Alkoiko kolmas vuosituhat vuoden 2000 alussa? Tarkkaan ottaen ei. Vuosituhat vaihtui vasta vuotta myöhemmin, vuoden 2001 alussa.

Miksi näin? Kerroimme aikaisemmin, miten nykyinen vuosien merkintätapa sai alkunsa apotti Dionysius Exiguuksen laskelmista. Hän määritteli pääsiäisjaksonsa alkamaan vuoden 1 alusta. "Jeesuksen syntymä" ajateltiin tammikuun alkuun, ja silloin alkoi vuosi 1 jKr. Seuraava vuosi oli $2 \mathrm{jKr}$ ja niin edelleen.

Englantilainen historioitsija Beda ulotti Dionysiuksen merkintätavan myös aikaisempiin vuosiin. Bedan kirjoituksissa vuotta 1 edeltävä vuosi oli 1 ennen Kristusta, sitä edeltävä 2 eKr jne.

Ajanlasku alkoi siis vuoden 1 alusta. Ensimmäiset kymmenen vuotta oli eletty vuoden 11 alkuun mennessä. (Vuoden 10 alkuun mennessä oli ajanlaskua kulunut vasta yhdeksän vuotta.)

Vastaavasti ensimmäiset sata vuotta tulivat täyteen vuoden 101 alussa. (Vuoden 100 alussa oli kulunut vasta 99 vuotta ajanlaskun alusta.) Ja ensimmäiset tuhat vuotta tulivat täyteen vuoden 1001 alussa. Silloin alkoi toinen vuosituhat. Kaksituhatta vuotta tuli täyteen vuoden 2001 alussa. Silloin alkoi kolmas vuosituhat.

Näinhän se tarkkaan ottaen on.

Arkinen käytäntö on kuitenkin muodostunut toisenlaiseksi. "Vuosikymmen" tarkoittaa tavallisessa puheessa aina pyöreätä kymmenlukua nollalla päättyvän vuoden alusta yhdeksiköllä päättyvän vuoden loppuun, esimerkiksi aikaa 1.1.1980-31.12.1989. Seuraavana päivänä alkaa uusi vuosikymmen.

Vastaavasti vuosisata tarkoittaa tavallisessa kielenkäytössä esim. vuoden 1900 alussa alkavaa satavuotisjaksoa. Ja vuosituhat esimerkiksi vuoden

\section{Viikonpäivien jakautuminen eri kuukauden- päiville gregoriaanisen kalenterin 400-vuotisessa jaksossa}

Taulukko on mukailtu Royal Greenwich Observatoryn Spectrum-lehdestä numero 16, lokakuu 1998.

\begin{tabular}{|c|c|c|c|c|c|c|c|c|c|}
\hline Päivä & Ma & $\underline{\mathrm{Ti}}$ & $\underline{\mathrm{Ke}}$ & $\underline{\text { To }}$ & $\underline{\mathrm{Pe}}$ & $\underline{\mathrm{La}}$ & $\underline{\mathrm{Su}}$ & Yht. & Tavallisin \\
\hline 1. & 684 & 687 & 685 & 685 & 687 & 684 & 688 & 4800 & sunnuntai \\
\hline 2. & 688 & 684 & 687 & 685 & 685 & 687 & 684 & 4800 & maanantai \\
\hline 3. & 684 & 688 & 684 & 687 & 685 & 685 & 687 & 4800 & tiistai \\
\hline 4. & 687 & 684 & 688 & 684 & 687 & 685 & 685 & 4800 & keskiviikko \\
\hline 5. & 685 & 687 & 684 & 688 & 684 & 687 & 685 & 4800 & torstai \\
\hline 6. & 685 & 685 & 687 & 684 & 688 & 684 & 687 & 4800 & perjantai \\
\hline 7. & 687 & 685 & 685 & 687 & 684 & 688 & 684 & 4800 & lauantai \\
\hline 8. & 684 & 687 & 685 & 685 & 687 & 684 & 688 & 4800 & sunnuntai \\
\hline 9. & 688 & 684 & 687 & 685 & 685 & 687 & 684 & 4800 & maanantai \\
\hline 10. & 684 & 688 & 684 & 687 & 685 & 685 & 687 & 4800 & tiistai \\
\hline 11. & 687 & 684 & 688 & 684 & 687 & 685 & 685 & 4800 & keskiviikko \\
\hline 12. & 685 & 687 & 684 & 688 & 684 & 687 & 685 & 4800 & torstai \\
\hline 13. & 685 & 685 & 687 & 684 & 688 & 684 & 687 & 4800 & perjantai \\
\hline 14. & 687 & 685 & 685 & 687 & 684 & 688 & 684 & 4800 & lauantai \\
\hline 15. & 684 & 687 & 685 & 685 & 687 & 684 & 688 & 4800 & sunnuntai \\
\hline 16. & 688 & 684 & 687 & 685 & 685 & 687 & 684 & 4800 & maanantai \\
\hline 17. & 684 & 688 & 684 & 687 & 685 & 685 & 687 & 4800 & tiistai \\
\hline 18. & 687 & 684 & 688 & 684 & 687 & 685 & 685 & 4800 & keskiviikko \\
\hline 19. & 685 & 687 & 684 & 688 & 684 & 687 & 685 & 4800 & torstai \\
\hline 20. & 685 & 685 & 687 & 684 & 688 & 684 & 687 & 4800 & perjantai \\
\hline 21. & 687 & 685 & 685 & 687 & 684 & 688 & 684 & 4800 & lauantai \\
\hline 22. & 684 & 687 & 685 & 685 & 687 & 684 & 688 & 4800 & sunnuntai \\
\hline 23. & 688 & 684 & 687 & 685 & 685 & 687 & 684 & 4800 & maanantai \\
\hline 24. & 684 & 688 & 684 & 687 & 685 & 685 & 687 & 4800 & tiistai \\
\hline 25. & 687 & 684 & 688 & 684 & 687 & 685 & 685 & 4800 & keskiviikko \\
\hline 26. & 685 & 687 & 684 & 688 & 684 & 687 & 685 & 4800 & torstai \\
\hline 27. & 685 & 685 & 687 & 684 & 688 & 684 & 687 & 4800 & perjantai \\
\hline 28. & 687 & 685 & 685 & 687 & 684 & 688 & 684 & 4800 & lauantai \\
\hline 29. & 641 & 644 & 642 & 642 & 643 & 641 & 644 & 4497 & tiistai, sunn \\
\hline 30. & 631 & 626 & 631 & 627 & 629 & 629 & 627 & 4400 & maan., kesk. \\
\hline 31. & 399 & 401 & 398 & 402 & 399 & 401 & 400 & 2800 & torstai \\
\hline & & & 371 & 871 & 0871 & 871 & 871 & 146097 & \\
\hline
\end{tabular}


1000 alussa alkavaa tuhannen vuoden jaksoa.

Siksi kaikkialla maailmassa juhlittiin vuosituhannen vaihtumista silloin, kun 1999 vaihtui vuodeksi 2000. Siitä huolimatta, että tuolloin Jeesuksen syntymästä oli kulunut jo yli 2000 vuotta ja ajanlaskumme alkuhetkestä vasta 1999 vuotta.

Ajanlaskun tutkijoiden täytyy olla tarkkana Jeesuksen syntymän aikaisia väliaikoja laskiessaan, kun vuosilukujen sarjassa ei ole vuotta nolla. Siksi

\section{Karkauspäivän uusi paikka}

elsingin yliopisto teki syksyllä 1998 päätöksen, että karkauspäivä siirretään Suomessakin helmikuun loppuun.

Vuosi 2000 oli karkausvuosi, jolloin helmikuussa oli yksi ylimääräinen päivä. Karkauspäivän paikkana pidetään Euroopassa yleisesti helmikuun viimeistä päivää. Pohjoismaissa oli kuitenkin näihin aikoihin asti noudatet-

tu kaksituhatta vuotta vanhaa perinnettä ja merkitty karkauspäivä helmikuun 24. päiväksi.

Karkauspäivä on ollut perinteisellä kohdalla ensimmäisestä Ruotsi-Suomen almanakasta vuodesta 1608 alkaen. Ruotsi luopui käytännöstä 1990luvun puolivälissä ja päätti siirtää vuodesta 2000 alkaen karkauspäivän helmikuun 29:nneksi.

Sellaisissa maissa, joissa kalentereissa ei ole nimipäiviä, ei karkauspäivän paikalla ole merkitystä. Helmikuuhun lisätään karkausvuonna vain yksi päivä, mutta kalentereista ei ilmene, mihin kohtaan päivä sijoitetaan. Luonnollinen ajatus on, että 29.2. on tuo ylimääräinen päivä.

Suomessa ja Ruotsissa on kullekin päivälle merkitty lähes kaikissa kalentereissa nimipäivät, ja vanhan tavan mukaan karkausvuosina 24.2. on merkitty karkauspäiväksi ja 24.2.-28.2. vietetyt nimipäivät siirretty yhdellä päivällä eteenpäin.

Ennen päätöksen tekemistä Helsingin yliopisto pyysi lausunnon yliopiston omilta merkkipäiväasiantuntijoilta. Assistentti Sirpa Karjalainen kansatieteen laitoksesta katsoi, että siirtoa ei ole syytä vastustaa. "Ainoa argumentti, jolla nykyisen käytännön jatkamista saattaisi perustella, on kaiketi se, että lukuisia kalenteriuudistuksia uhmanneen vanhan roomalaisen tradition ylläpitäminen olisi sinänsä vaalimisen arvoinen kuriositeetti", totesi Karjalainen.

Helsingin yliopisto kuitenkin katsoi siirron edut suuremmiksi kuin haitat, ja siksi Suomessakin on vuodesta 2000 alkaen ollut karkauspäivä helmikuun lopussa.

\begin{tabular}{|c|c|c|c|c|}
\hline & \multicolumn{3}{l}{$\mid$} \\
\hline & & & & \\
\hline \\
\hline
\end{tabular}

Ajanlaskumme alkuvuodet tavallisen ajanlaskun mukaan (ylempi viiva) ja tähtitieteilijöiden käytännön mukaan (alempi viiva). Tavallisessa ajanlaskussa ei ole vuotta nolla.

tähtitieteilijät, jotka joutuvat usein laskemaan ennen ajanlaskumme alkua tapahtuneita taivaan ilmiöitä, ovat omassa laskutavassaan ottaneet nollavuoden mukaan. Näin numerot seuraavat toisiaan samalla tavalla kuin tavallisessa lukusuorassa. Normaalin ajanlaskumme vuosi $1 \mathrm{eKr}$ on tähtitieteilijöillä vuosi nolla, normaalin ajanlaskun vuosi $2 \mathrm{eKr}$ on tähtitieteilijöillä vuosi miinus yksi jne.

Näin tähtitieteellisessä ajanlaskussa voidaan väliaikoja laskea samalla tavalla kuin esimerkiksi lämpötilaeroja lämpömittarissa.

\section{Babylonialaisesta jutalaiseen kalenteriin}

Juutalaisten nykyinen kalenteri on kehittynyt Babyloniassa käyttöön otetusta kalenterista. Babylonialaisessa kuu-aurinkokalenterissa aloitettiin kuukausi aina kuunsirpin ilmestyessä ensimmäisen kerran iltataivaalle. Tavallisesti vuodessa oli 12 kuukautta, mutta aina välillä jouduttiin laskemaan vuoteen vielä kolmastoista kuun kierto, jotta kuukaudet olisivat pysyneet suunnilleen samassa kohdassa vuoden kiertoa.

Vuoden $600 \mathrm{eKr}$ paikkeilla Babyloniassa oli vakiintunut kaava, jonka mukaan ylimääräisiä kuukausia lisättiin. Yhdeksäntoista vuotta kestävässä jaksossa lisättiin 13. kuukausi seitsemänä vuonna: kolmantena, kuudentena, kahdeksantena, yhdentenätoista, neljäntenätoista, seitsemäntenätoista ja yhdeksäntenätoista. Tätä karkausjaksoa sanotaan nykyään Metonin jaksoksi, koska kreikkalainen Meton parisataa vuotta myöhemmin vakiinnutti samat karkausvuodet kreikkalaiseen kalenteriin.

Metonin jakso on hyvin tarkka, sillä 19 vuoden kuluttua kuukausi alkaa vain 0,08 vuorokautta myöhemmin kuin edellisessä jaksossa. Vuosi pysyy siten parin tunnin tarkkuudella oikeassa tahdissa vuodenaikojen suhteen. 


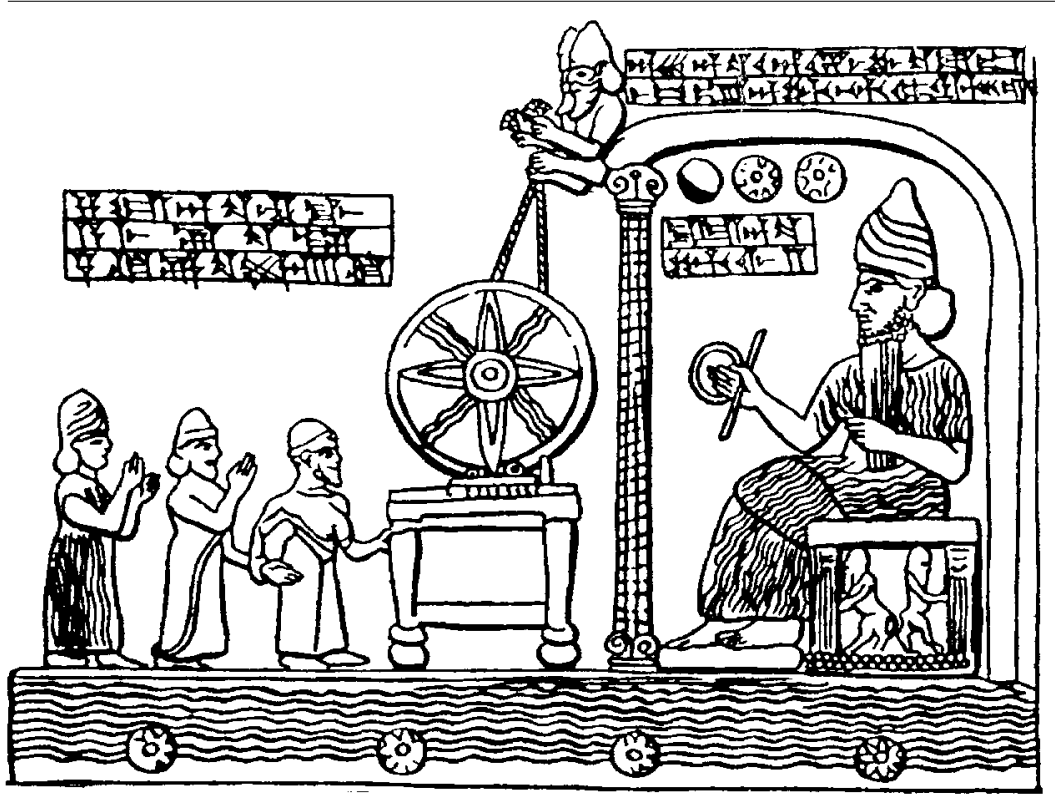

Juutalainen kalenteri on saanut monia piirteitä vanhasta babylonialaisesta ajanlaskusta.

Israelin kansa oli vankeudessa Babyloniassa vuosien 586-538 eKr paikkeilla ja lainasi vankeusmatkaltaan isäntiensä kalenterin. Nykyaikaisessa juutalaisessa kalenterissa karkauskuukaudet lisätään saman Metonin kaavan mukaan, ja kuukausien nimet ovat lähes samat kuin 3000 vuotta sitten Babyloniassa. Kuukausien pituuksissa on kuitenkin tapahtunut hieman muutoksia. Babylonialaisilla kuukaudet olivat vuorotellen 29 ja 30 päivän pituisia (sillä kuun vaiheiden jakso on noin 29,5 vuorokautta). Juutalaisilla parin kuukauden pituus on päivän verran vaihtuva, ja päiviä lisäämällä tai poistamalla voidaan hieman säädellä muutaman juhlapäivän viikonpäivää.

Juutalaisilla sapatti (lauantai) on niin pyhä päivä, että vuoden alkupäivän ei sallita osua lauantaille. Vuoden kymmenes päivä, sovitusjuhla, ei taas saa sattua lauantaita edeltävään tai seuraavaan päivään.

Juutalaisten 12-kuukautinen vuosi voi olla "vajaa" (353 päivää), "normaali" (354 päivää) tai "täydellinen" (355 päivää). Samoin voi 13-kuukautinen karkausvuosi olla 383-, 384- tai 385-päiväinen.

Juutalaisen kalenterin periaatteet pysyivät papiston salaisuutena 350-

\section{Juutalaisen kalenterin kuukaudet}

\begin{tabular}{|c|c|c|}
\hline$\frac{\text { Babylonialainen }}{\text { kuukaudennimi }}$ & $\begin{array}{l}\text { Luutalaisen kalenterin } \\
\text { kuukaudennimi }\end{array}$ & $\begin{array}{l}\text { Luutalaisen kuu- } \\
\text { kauden pituus (d) }\end{array}$ \\
\hline Tashritu & Tišrí & 30 \\
\hline Arasammu & Hešván & 29 tai 30 \\
\hline Kislinu & Kislév & 30 tai 29 \\
\hline Tebetu & Tevét & 29 \\
\hline Shabatu & Ševát & 30 \\
\hline Addaru & Adár* & 29 \\
\hline Nisanu & Nisán & 30 \\
\hline Airu & Ijjár & 29 \\
\hline Simanu & Siván & 30 \\
\hline Duzu & Tammúz & 29 \\
\hline $\mathrm{Abu}$ & $\mathrm{Ab}$ & 30 \\
\hline Ululu & Elúl & 29 \\
\hline
\end{tabular}

*Karkausvuonna adár-kuu on nimeltään adár II. Sitä edeltää karkauskuukausi, 30-päiväinen adár I.

luvulle jKr asti, jolloin patriarkka Hillel II julkaisi ne kaikkien tietoon. Kuukausien päivien lukumäärä vakiintui nykyiselleen noin vuoden 1000 paikkeilla. Juutalainen kalenteri on siten vanhimpia muuttumattomina säilyneitä kalentereita, joka on edelleen käytössä. Juutalainen kalenteri on Israelin virallinen kalenteri, ja sitä käytetään juutalaisyhdyskunnissa ympäri maailmaa.

Juutalaisen ajanlaskun alkukohtana pidetään maailman luomista, joka perimätiedon mukaan tapahtui lokakuun 7. päivänä vuonna $3761 \mathrm{eKr}$ (juliaanisen kalenterin mukaan). Juutalaisten vuosi vaihtuu syyspäiväntasauksen tienoilla, ja esimerkiksi syyskuun 4. päivänä vuonna 2013 alkaa vuosi 5774 .

Juutalaisen kalenterin suurimmat juhlat on määritelty jo Vanhassa Testamentissa, ja niitä vietetään edelleen samoilla paikoilla. Vuosi alkaa uudenvuodenjuhlalla, joka aloittaa kymmenpäiväisen katumusjakson. Katumus päättyy suureen sovituspäivään, joka on juutalaisilla paastopäivä. Hepreaksi se tunnetaan nimellä jom kippúr. Viisi päivää myöhemmin alkaa kahdeksanpäiväinen kiitosjakso, lehvämajanjuhla. 
Myös pääsiäinen eli pésah, joka alkaa nisánkuun 15. päivänä, on kahdeksanpäiväinen juhla. Silloin muistellaan juutalaisten vapautumista Egyptistä. Juutalaisen kalenterin juhlapäivät on lueteltu kunakin vuonna perinteisessä Yliopiston almanakassa ja Valtiokalenterissa.

\section{Islamilainen kalenteri}

Islamilainen kalenteri on käytössä pääasiassa Turkissa, Arabian niemimaalla, Egyptissä ja osissa Intiaa ja Malaijan niemimaata. Myös Iranissa käytetään islamilaista kalenteria pyhien määräämiseen, mutta muuten ns. persialaista kalenteria.

Islamilainen kalenteri on sidottu pelkästään kuun vaiheisiin. Kuukausia on vuodessa 12, ja niiden pituus on vuorotellen 29 ja 30 päivää. Vuoden pituus on siten 354 päivää.

Jotta kalenteri pysyisi tarkalleen tahdissa kuun vaiheiden kanssa, kussakin 30 vuoden jaksossa lisätään yhteentoista vuoteen yksi karkauspäivä. Se liitetään vuoden loppuun 355. päiväksi. Karkausvuosia ovat 30-vuotisen jakson vuodet 2, 5, 7, 10, 13, 16, 18, 21, 24, 26 ja 29. Kuukauden keskipituus on islamilaisten karkaussäännöllä vain 2,9 sekuntia lyhempi kuin kuun vaiheiden jakso, ja siksi islamilainen kalenteri seuraa hyvin täsmällisesti kuun todellista kiertoa.

Joillakin alueilla islamilaiset laskevat kunkin kuukauden alun todellisen uudenkuun mukaan. Kuukausi alkaa silloin kun kapea kuun sirppi

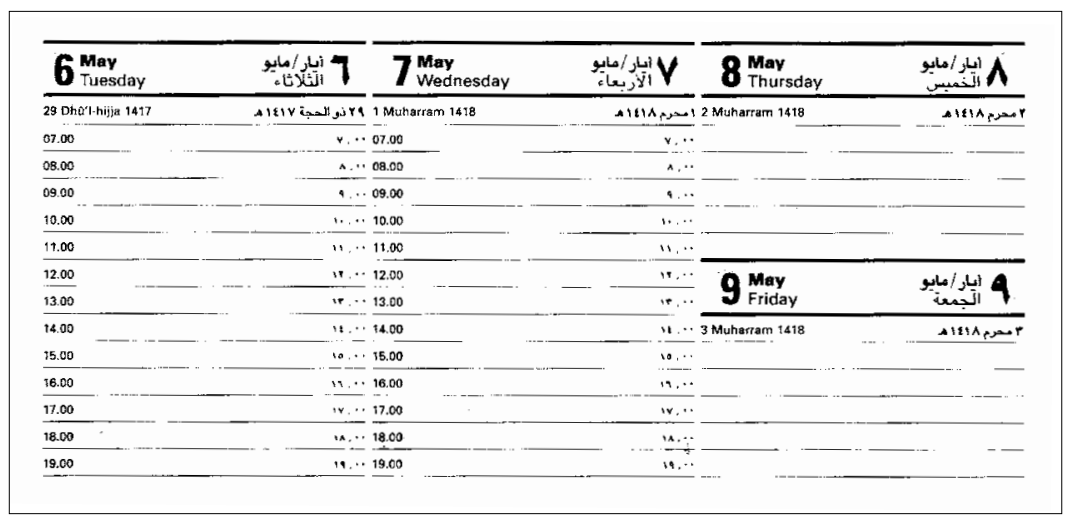

Sivu nykyaikaisesta islamilaisesta kalenterista. Keskiviikkona alkaa islamilaisten vuosi 1418. Perjantai on pyhäpäivä. (Kalenteri Charles Letts \& Co) ensimmäisen kerran näkyy iltataivaalla. Varsinkin uskonnolliset juhlat määrätään yleensä sen mukaan, milloin kuun sirppi ilmestyy näkyviin islaminuskoisten pyhässä kaupungissa Mekassa. Siviilikalenteri useimmiten lasketaan ylläolevien sääntöjen mukaan.

Koska kalenteri on sidottu vain kuun kulkuun, se ei pysy vuodenaikojen tahdissa. Vuoden alku siirtyy toistakymmentä päivää aikaisemmaksi joka vuosi ja kiertää koko vuoden ympäri noin 33 vuodessa.

Islamilaisen kalenterin viikko on seitsenpäiväinen, ja päivät lasketaan auringonlaskusta auringonlaskuun. Päivillä on vain numeromerkinnät lukuun ottamatta rukouksille omistettua viidettä päivää, jonka nimi on Jum'a. Päivä 1 alkaa sunnuntaina auringonlaskun aikaan, ja päivä 5 kestää siten meidän torstai-illastamme perjantai-iltaan. Jum'a ei kuitenkaan ole vapaapäivä kuten kristittyjen sunnuntai tai juutalainen sapatti.

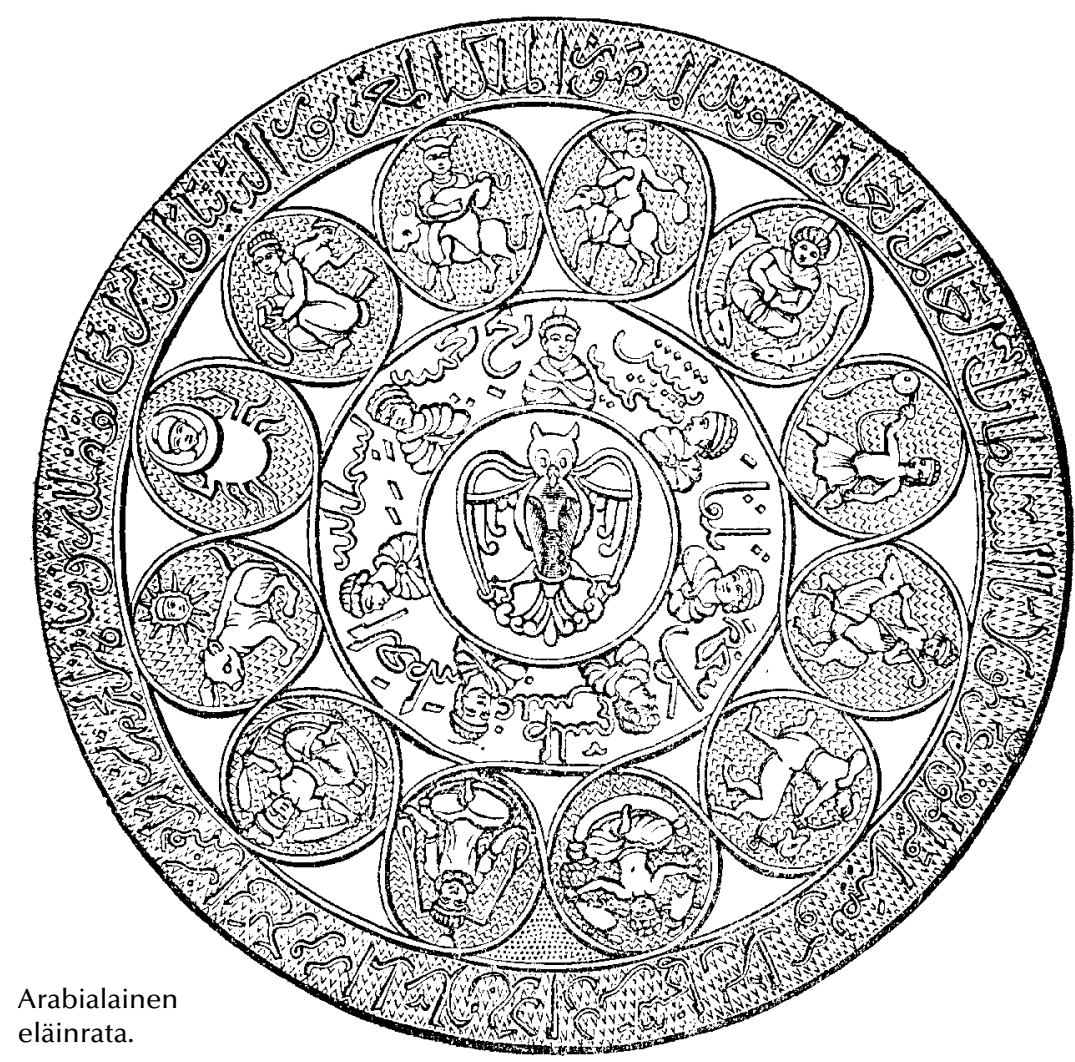


Islamilaisen ajanlaskun peruspäiväksi on valittu (juliaanisen kalenterin) 16. heinäkuuta vuonna 622, jolloin Muhammed pakeni Mekasta Medinaan. Profeetta itse määritteli uuden kalenterin periaatteet islamin pyhässä kirjassa Koraanissa. Uuden kalenterin oli määrä syrjäyttää siihenastinen kuu-aurinkokalenteri. Kalenteri otettiin käyttöön kalifi 'Umar I:n aikana 16 vuotta myöhemmin.

Vuoden 2012 joulukuussa alkoi islamilaisen kalenterin vuosi 1434.

Islamin kalenterin yhdeksäs kuukausi, ramadankuu on paastokuukausi, joka päättyy kolmipäiväiseen Id al-Fitr -juhlaan. Sen viettotavoissa on samoja piirteitä kuin meidän joulussamme. Muita islamin suuria juhlapäiviä ovat esimerkiksi pyhiinvaellusjuhla eli Id al-Ad'ha, uusivuosi eli al-Hidžra ja Muhammedin syntymäpäivä Milad al-Nabi. Islamilaisten tärkeimmät juhlat luetellaan vuosittain Yliopiston almanakassa ja Valtiokalenterissa.

\section{Kiinalainen kalenteri}

Kiinassa kehittyi kuun ja auringon jaksoihin perustuva kalenteri jo toisella vuosituhannella ennen ajanlaskumme alkua. Keisarin alaisuudessa

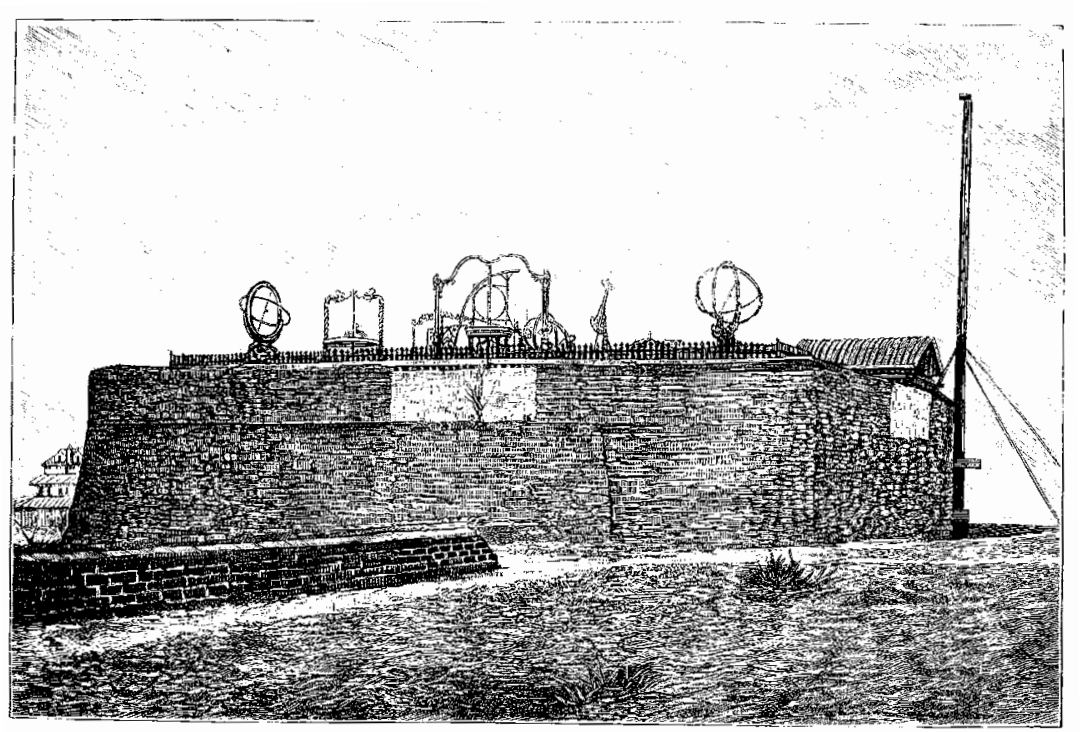

Kiinan hallitsijalla oli apunaan tähtitieteilijöitä, jotka tarkoilla laitteillaan seurasivat taivaan tapahtumia. Kuvassa Pekingin vanha observatorio. toimi tähtitieteen toimisto, jonka yhtenä tehtävänä oli kalenterin laskeminen.

Kuukaudet alkoivat todellisina uudenkuun hetkinä, ei kuunsirpin ensimmäisestä näkymisestä kuten esimerkiksi islamilaisessa kalenterissa. Nykyäänkin uuden kuukauden ensimmäinen päivä on se vuorokausi (keskiyöstä keskiyöhön), jolle uudenkuun hetki sattuu laskettuna 120. itäisen pituuspiirin eli suunnilleen Beijingin mukaan. Tavallisesti vuodessa on 12 kuukautta, mutta kahden tai kolmen vuoden välein lisätään yksi karkauskuukausi, jotta vuodenvaihde pysyy oikeassa kohdassa.

Kiinalainen vuodenvaihde on talvella talvipäivänseisauksen ja kevätpäiväntasauksen puolivälin tienoilla. Vuosi alkaa yleensä ensimmäisenä uudenkuun hetkenä sen jälkeen, kun aurinko on siirtynyt Vesimiehen merkkiin, käytännössä välillä 20.1.-19.2.

Kiinalaiset eivät laske vuosilukuja mistään tietystä alkuhetkestä lähtien, vaan vuodet toistuvat kuudenkymmenen vuoden jaksossa. Vuosien

Kiinalaisissa kalentereissa käytetään paljon symboleita. Kuvassa vuoden 2010 lohikäärmevenejuhlan päivä (16.6.) repäistävässä seinäkalenterissa.

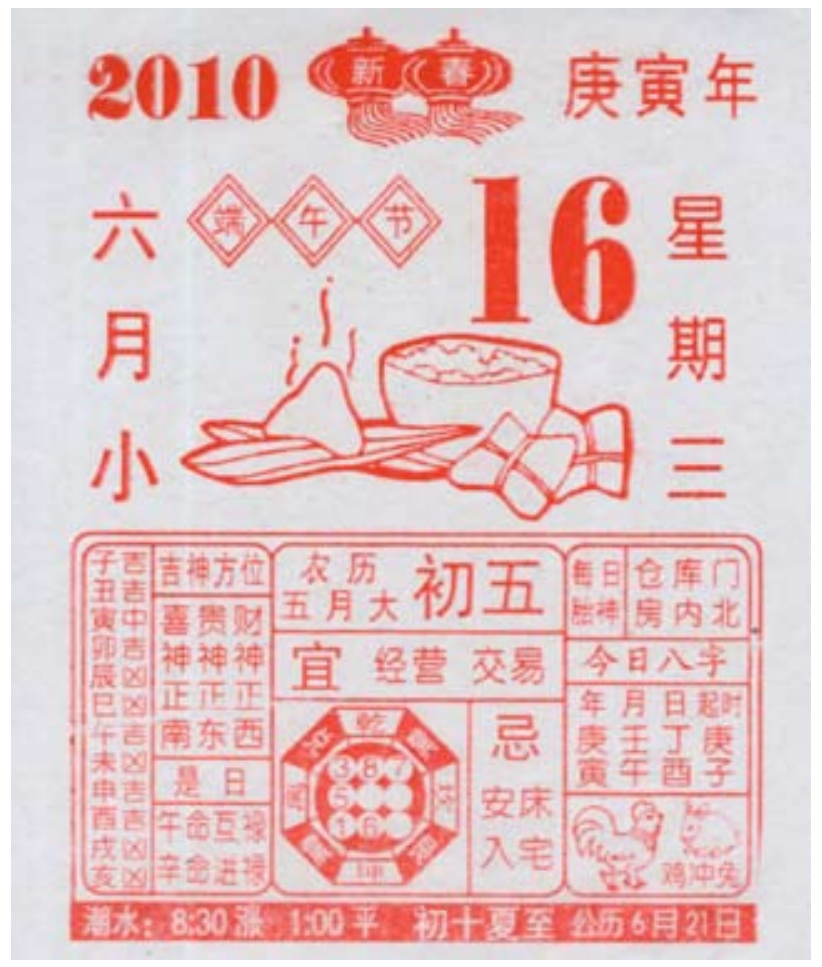




\section{Kiinalaisen kalenterin 60-vuotinen jakso}

\section{Taivaalliset kannat}

1. jia

2. yi

bing

ding

wu

$\mathrm{ji}$

geng

8. xin

9. ren

10. gui

Vuosien nimet

1. jia-zi

yi-chou

bing-yin

ding-mao

wu-chen

ji-si

geng-wu

xin-wei

ren-shen

gui-you

jia-xu

yi-hai

\section{bing-zi}

ding-chou

wu-yin

ji-mao

geng-chen

xin-si

ren-wu

gui-wei

jia-shen
Maalliset haarat

1. zi, rotta

2. chou, härkä

yin, tiikeri

mao, jänis

chen, lohikäärme

si, käärme

wu, hevonen

wei, lammas

shen, apina

you, kukko

$\mathrm{xu}$, koira

hai, sika

yi-you

bing-xu

ding-hai

wu-zi

ji-chou

geng-yin

xin-mao

ren-chen

gui-si

jia-wu

yi-wei

bing-shen

ding-you

wu-xu

ji-hai

geng-zi

xin-chou

ren-yin

gui-mao

41. jia-chen
42. yi-si

43. bing-wu

44. ding-wei

45. wu-shen

46. ji-you

47. geng-xu

48. xin-hai

49. ren-zi

50. gui-chou

51. jia-yin

52. yi-mao

53. bing-chen

54. ding-si

55. wu-wu

56. ji-wei

57. geng-shen

58. xin-you

59. ren-xu

60. gui-hai

\section{Kiinalainen eläinrata.}

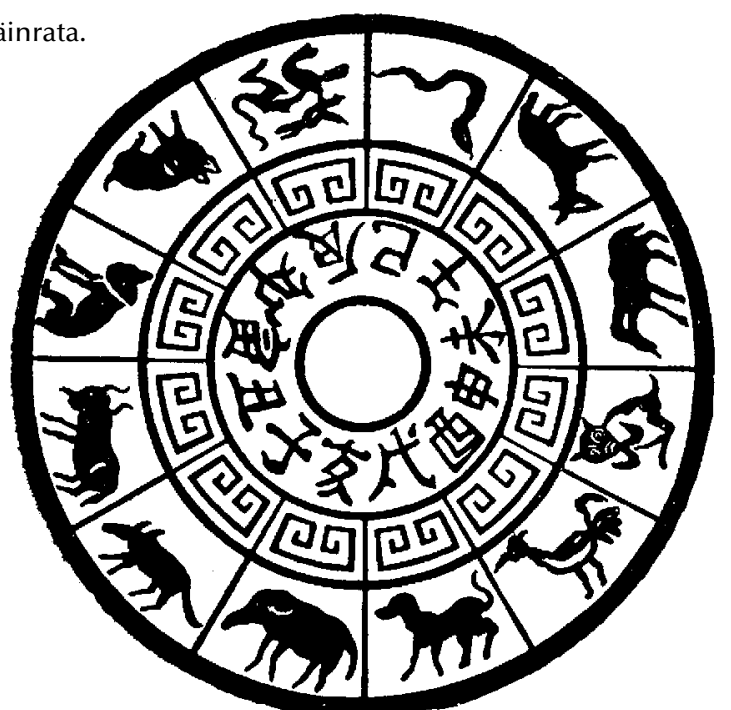

nimet saadaan yhdistämällä "taivaallisen kannan" kymmenen merkkiä pareiksi "maallisen haaran" kahdentoista merkin kanssa. Taivaallisen kannan nimillä ei ole muunkielisiä käännöksiä, kun taas maallisen haaran nimet vastaavat kahdentoista eläimen nimeä.

Kuudenkymmenen vuoden jakson aikana toistuvat taivaallisen kannan merkit kuusi kertaa ja maallisen haaran merkit viisi kertaa oheisen taulukon mukaisesti. Sen jälkeen alkaa uusi 60-vuotinen jakso. Nykyinen jakso käynnistyi vuoden 1984 helmikuun 2. päivänä, jolloin alkoi rotan vuosi 1 , jia-zi.

Perinteinen kiinalainen kalenteri oli voimassa vallankumoukseen asti. Vuodesta 1911 lähtien virallinen Kiina on noudattanut länsimaista gregoriaanista kalenteria. Vanhaa kalenteria käytetään edelleen juhlapäivien määräämiseen ja maaseudulla pelto- ja metsätöiden aloittamiseen.

Kiinalaisten suurin juhla on perinteisen uudenvuoden alku eli kevätjuhla, joka on kolmipäiväinen. Sitä vietetään ensimmäisenä uudenkuun päivänä sen jälkeen, kun aurinko on siirtynyt Vesimiehen merkkiin. Vuonna 2013 kevätjuhla alkoi helmikuun 10. päivänä. Siinä yhdistyy meikäläisen joulun ja uudenvuoden viettotapoja.

Vuonna 2009 uudistettiin kiinalainen juhlakalenteri. Kommunistisen ajan juhlia typistettiin (esimerkiksi vappu palautettiin yksipäiväiseksi), ja tilalle otettiin perinteisiä kiinalaisjuhlia. Niinpä takaisin kunniaan pää- 
sivät haudanlakaisupäivä huhtikuun alussa, lohikäärmevenejuhla toukokesäkuussa ja keskisyksyn juhla eli kuukakkujuhla syys-lokakuussa.

\section{Intian kalenteri}

Intiassa oli 1900-luvun puolivälissä käytössä jopa 30 erilaista kalenteria eri uskontokunnilla ja eri paikkakunnilla. Valtio asetti tuolloin kalenterinuudistamistoimikunnan. Sen ehdotusten perusteella Intia sai 1957 uuden virallisen kalenterin, johon oli otettu piirteitä useista eri lähteistä.

Vuoden pituus on täsmälleen sama kuin gregoriaanisessa kalenterissa, ja karkauspäivä lisätään samoina vuosina kuin meillä. Karkauspäivän paikka on kuitenkin erilainen (huhtikuun 20. päivän paikkeilla) ja vuosi alkaa kevätpäiväntasauksen aikoihin.

Vuodessa on 12 kuukautta, jotka eivät ole sidottuja todellisen kuun vaiheisiin. Kuukausista viisi on 31-päiväistä (karkausvuonna kuusi), ja loput ovat 30-päiväisiä.

Vuosiluvut lasketaan siten, että vuosi 1 alkoi meidän vuotemme 79 kevätpäiväntasauksena. Kalenteriuudistus 1957 astui voimaan Intian kalenterivuoden 1879 alussa.

Viikonpäivät ovat samat kuin länsimaissa.

Siviilikalenterin rinnalla on Intiassa käytössä todellisiin kuun vaiheisiin ja auringon liikkeeseen perustuva uskonnollinen kalenteri. Se määrää uskonnollisten juhlapäivien paikat. Hindulaisilla, buddhalaisilla ja muilla uskontokunnilla on edelleen omia juhlapäiviään, ja samoin Intian eri osavaltioissa vietetään eri juhlapäiviä. Yleisiä valtakunnallisia vapaapäiviä on vain kolme, ja ne liittyvät Intian valtiolliseen historiaan: tasavallan päivä 26.1. (meidän ajanlaskumme mukaan), itsenäisyyspäivä 15.8. ja Mahatma Gandhin syntymäpäivä 2.10.

\section{Vallankumouksellisia kalentereita}

Vallankumouksissa on aina haluttu kaataa, paitsi edellinen hallinto, myös monia muita vanhoja tapoja. Viime vuosisatoina on kaksi eurooppalaista vallankumousta perustanut kokonaan omat kalenterinsa.

Ranskan vallankumouksen jälkeen 1792 haluttiin päästä eroon sekä vanhentuneesta mittajärjestelmästä että entisestä kalenterista. Mitoissa siirryttiin jaloista, paunoista ja tuumista metreihin, kiloihin ja niiden desimaaliosiin. Metrimittoihin siirtyminen osoittautui onnistuneeksi ratkaisuksi, ja Ranskan vallankumousta seuraten on lähes koko Eurooppa kahtena seuraavana vuosisatana siirtynyt metrimittoihin.

Kalenterikin suunniteltiin hyvin järkevältä pohjalta, ja kalenterin tekoon osallistui suuri joukko silloisen Ranskan terävimpiä tiedemiehiä. Vuosi jaettiin kahteentoista kuukauteen, ja jokaisessa kuussa oli tasan 30 päivää. Näin saatiin 12 kuukauteen yhteensä 360 päivää. Lisäksi vuoden loppuun lisättiin viisi (karkausvuonna kuusi) ylimääräistä vapaapäivää, jotta vuosi saatiin oikeanpituiseksi.

Kuukaudet ilmaistiin aluksi pelkillä järjestysnumeroilla I-XII, mutta pari vuotta myöhemmin niille annettiin vuodenaikoja kuvaavat nimet.

Vuodenvaihde ei ollut talvella, vaan syyspäiväntasauksena eli gregoriaanisen kalenterin syyskuun 22. tai 23. päivänä.

Seitsenpäiväinen viikko hylättiin, ja jokainen kuukausi jaettiin kolmeen kolmannekseen. Kussakin kymmenpäiväisessä kolmanneksessa oli vain yksi vapaapäivä. Tämä tietysti herätti katkeruutta ranskalaisissa työ-

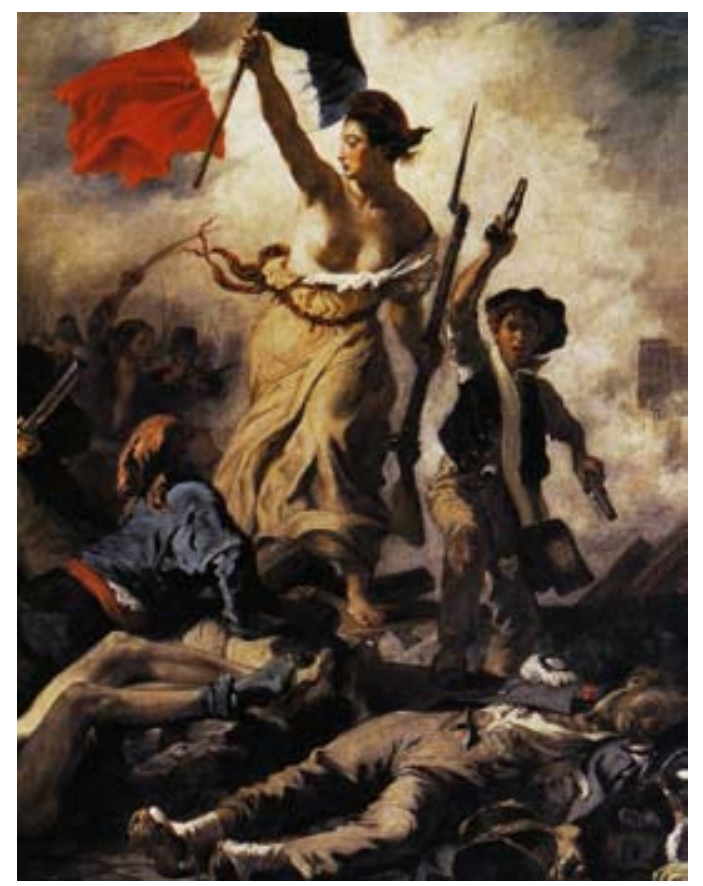

Vapauden jumalatar. Rans kan vallankumous uudisti myös mittajärjestelmän ja kalenterin. 
läisissä, jotka joutuivat raatamaan yhdeksän päivää peräkkäin, kun rajan takana päästiin lepäämään aina kuuden työpäivän jälkeen.

Vallankumouskalenteria yritettiin parannella vuosien varrella. Asiaa ei juurikaan auttanut se, että useita tiedemiehiä, jotka olivat kalenteria rakentaneet, mestattiin.

Napoleon nousi valtaan vallankumouksen vuonna VIII (marraskuussa 1799). Hän antoi kirkoille luvan järjestää jälleen jumalanpalveluksia, ja kansa meni entisinä sunnuntaipäivinä kirkkoon, olipa mikä päivä kolmanneksessa tahansa.

Vuonna 1806, neljätoista vuotta syntymänsä jälkeen, vallankumouskalenteri haudattiin lopullisesti ja Ranska siirtyi uudelleen käyttämään gregoriaanista kalenteria.

Myös Venäjän vallankumous 1917 hylkäsi siihenastisen kalenterin. Tämä olikin järkevä teko, sillä Venäjällä oli noudatettu vanhaa juliaanista kalenteria. Uusi hallitus otti käyttöön saman gregoriaanisen kalenterin, jota käytettiin muuallakin länsimaissa.

1920-luvun lopulla haluttiin kuitenkin luopua myös gregoriaanisesta kalenterista. Silloin otettiin Ranskan vallankumouksen mallin mukaan käyttöön kaksitoista 30-päiväistä kuukautta, ja vuoteen lisättiin viisi tai kuusi vapaapäivää.

Myös Venäjällä luovuttiin seitsenpäiväisestä viikosta. Aluksi kukin kuukausi jaettiin kuuteen 5-päiväiseen viikkoon. Paria vuotta myöhemmin kalenteria muutettiin ja kuukaudet jaettiin viiteen 6-päiväiseen viikkoon.

Siinä vaiheessa uudistukset olivat saaneet tavallisen kansalaisen elämän niin sekaisin, että he eivät enää olleet selvillä työ- ja vapaapäivistään. Myös hallitus huomasi tilanteen sekavuuden, ja vuonna 1940 Neuvostoliitto palasi noudattamaan tavallista gregoriaanista kalenteria.

Kiinassa vaihdettiin kalenteri 1911, ja kommunistien tullessa valtaan 1940-luvun lopulla muutettiin myös aikavyöhykejärjestelmää (aikavyöhykkeistä enemmän kirjamme sivuilla 86-94). Kiinassa oli vuonna 1912 otettu käyttöön viisi eri aikavyöhykettä, joilla aika vaihteli GMT+3,5 tunnista GMT+8,5 tuntiin. Vuonna 1949 Kiinan uusi kommunistinen hallinto päätti, että uusi Kiina käyttää kaikkialla samaa aikaa. Siksi Kiinassa on edelleenkin vain yksi aikavyöhyke, GMT $+8 \mathrm{~h}$, vaikka aurinkoaika poikkeaa itäisimmässä Kiinassa neljä tuntia läntisimmän Kiinan ajasta.

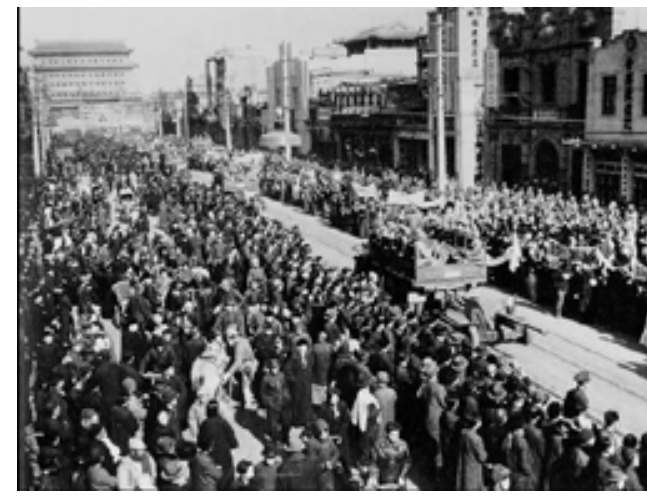

Vapautusarmeija saapuu Pekingiin vuonna 1949. (Kuva Wikipedia)

Aikavyöhyke GMT+8 vastaa tiheäään asutun itärannikon ja mm. Beijingin ja Shanghain luonnollista aikaa. Läntisin Kiina antaa kuitenkin hieman periksi luonnolle, sillä siellä kaupat ja toimistot avautuvat aamulla tunnin tai pari myöhemmin kuin itäosissa.

\section{Juliaaniset päivämäärät}

Maailmassa on käytössä ehkä nelisenkymmentä erilaista kalenteria, ja menneinä aikoina niitä on ollut vielä enemmän. Kussakin kalenterissa on omat vuosilukunsa, omat kuukautensa, omat karkauspäivänsä.

Kaiken tämän sekasotkun keskelle kehitti Justus Scaliger -niminen tutkija 1600-luvulla uudenlaisen laskutavan, jossa numeroidaan pelkkiä päiviä. Maapallo on pyörinyt akselinsa ympäri tasaisesti jo miljoonat vuodet. Kaikki maapallon tapahtumat voidaan sijoittaa yhdelle ja samalle aikajanalle, jos käytetään vain päivänumeroita.

Justus Scaliger etsi uudelle laskutavalleen nollavuoden niin kaukaa menneisyydestä, että sitä ennen tuskin on löydettävissä kirjallisia historiallisia dokumentteja. Vuorokausi 1 oli vuoden $4713 \mathrm{eKr}$ tammikuun 1. päivä. Siitä eteenpäin päivänumero kasvoi 365:llä tai 366:lla jokaista auringon kiertoa kohti. Vuoden 2013 tammikuun ensimmäisenä päivänä kirjattiin jo juliaaninen päivämäärä 2456 294, tammikuun toisena päivänä 2456295 ja niin edelleen.

Nimestään huolimatta juliaanisilla päivämäärillä ei ole mitään tekemistä Julius Caesarin kanssa. Justus Scaligerin kerrotaan antaneen uudelle laskutavalleen nimen isänsä Julius Scaligerin mukaan. 
Juliaanista päivämäärää käyttävät historiantutkijoiden ohella varsinkin tähtitieteilijät, jotka tutkivat entisaikojen pimennyksiä tai muita tähtitieteellisiä havaintoja maapallon eri puolilla.

\section{Ehdotuksia uudeksi kalenteriksi}

Nykyinen kalenterimme on varsinainen sillisalaatti, joka on syntynyt monien mutkien kautta. Jos nyt saisimme lähteä puhtaalta pöydältä ja suunnitella järkevimmän mahdollisen kalenterin, mikä mahtaisi olla lopputulos?

Kuten edellä nähtiin, yhtä "järkevää" kalenteria yriteltiin jo Ranskan vallankumouksen aikaan. Se kaatui siihen, että muutokset aikaisempaan kalenteriin ja naapurimaiden kalentereihin olivat liian suuret. Varsinkin perinteisen seitsenpäiväisen viikon hylkääminen sai kansan takajaloilleen.

Puhutaan siis tässä vain sellaisista kalentereista, joissa viikko jatkaa samaa tuttua jaksoaan, jaksoa jota se on yhtämittaisesti noudattanut jo useiden tuhansien vuosien ajan.

Kansainliitto perusti 1923 komitean tutkimaan kalenterin uudistusmahdollisuuksia, ja mietinnössään komitea pohti 185 erilaista kalenteria. Niistä ehkä varteenotettavin vaihtoehto oli sellainen, jossa vuosi on jaettu neljään yhtä pitkään neljännekseen. Kukin neljännes on 91-päiväinen ja käsittää kolme kuukautta, joista kaksi on 30-päiväistä ja yksi 31-päiväinen. Näin kuukausien pituuksia jouduttaisiin muuttamaan nykyiseen verrattuna vain vähän. Koska 91 on tasan jaollinen seitsemällä, toistuisivat viikonpäivät joka neljänneksessä samoina. Kukin neljännes alkaisi esimerkiksi sunnuntailla, jolloin neljänneksen toinen kuukausi alkaisi aina tiistailla ja kolmas kuukausi torstailla.

Neljä 91-päiväistä neljännestä tekee yhteensä 364 vuorokautta. Koska maapallon kierto auringon ympäri vie runsaat 365 vuorokautta, täytyy vuoden loppuun liittää yksi tai karkausvuonna kaksi ylimääräistä päivää, joita ei lasketa kuuluvaksi mihinkään kuukauteen tai mihinkään viikkoon. Näin viikkorytmi katkeaisi päiväksi tai kahdeksi, mutta jatkuisi sitten taas seuraavaan vuodenvaihteeseen asti.

Mikä olisi järkevin karkausvuosien sijoittelu? Paavi Gregorius XIII arveli 1500-luvulla, että karkausvuosisäännössä on yksinkertaisinta tehdä poikkeuksia sadalla ja 400:lla jaollisten vuosien kohdalla. Järkevämpää olisi kuitenkin ollut, kuten Paul Kustaanheimo laskee kirjassaan Läheinen ja kaukainen avaruus, että joka neljännen vuoden karkaussääntö olisi voimassa aina 128 vuotta kerrallaan. Jos karkausvuosi toistuisi neljän vuoden välein, mutta joka 128 . vuosi jätettäisiin karkausvuosi pitämättä, päästäisiin tällä yhdellä poikkeuksella suurempaan tarkkuuteen kuin Gregorius XIII pääsi kahdella poikkeuksella. Gregoriaaniseen kalenteriin kertyy vuorokauden virhe jo vajaassa 3000 vuodessa, mutta Kustaanheimon tavalla laskien tulee vuoden pituuteen päivän virhe vasta 400000 vuodessa.

Sekavan kalenterimme uudistamiseen on esitetty monia muitakin mahdollisuuksia. Jos viikkorytmin halutaan säilyvän vuodenvaihteessakin häiriintymättömänä, täytyy koko vuosi lyhentää 364 päivään eli 52 viikkoon ja lisäillä vuoteen aika ajoin karkausviikkoja, ei yksittäisiä karkauspäiviä.

Oikea vuoden pituus löytyy silloin, jos karkaussääntö sovitaan seuraavaksi: joka viides vuosi on karkausvuosi, jossa on 53 viikkoa. Poikkeuksena ovat 40:llä jaolliset vuodet, joihin ei liitetä karkausviikkoa. Poikkeuksen poikkeuksena ovat 400:lla jaolliset vuodet, joihin liitetään lisäviikko. Tämä karkaussääntö antaa vuoden pituudelle täsmälleen saman arvon kuin nykyinen kalenteri.

Kun länsimaiset ihmiset ovat tottuneet nykyiseen kalenteriin, eivät "järkevämmät" kalenterit tarjoa paljonkaan parempia vaihtoehtoja. Muutosten aiheuttama sekaannusten pelko saa aikaan sen, että nykyistä kalenteria ei hevin lähdetä muuttamaan. Meidän täytyy tyytyä siihen, että maapallomme pyörähdysaika akselinsa ympäri ja kiertoaika auringon ympäri ovat niin huonosti yhteensopivia mittoja, että niiden varaan ei "hyvää" kalenteria kerta kaikkiaan pystytä tekemään.

Jos kalenteriamme uudistetaan, on meidän paras tehdä vain hyvin pieniä muutoksia kerrallaan. Järkevin pieni muutos tällä hetkellä olisi varmaan se, että pääsiäinen kiinnitettäisiin johonkin tiettyyn viikonloppuun eikä annettaisi sen (ja pääsiäisen mukana monen muun keväisen pyhäpäivän) vaellella yli kuukauden verran paikasta toiseen vain kuun kierron ja kevätpäiväntasauksen yhteensopimisen tai -sopimattomuuden vuoksi. 


\section{AJANMITTAUS}

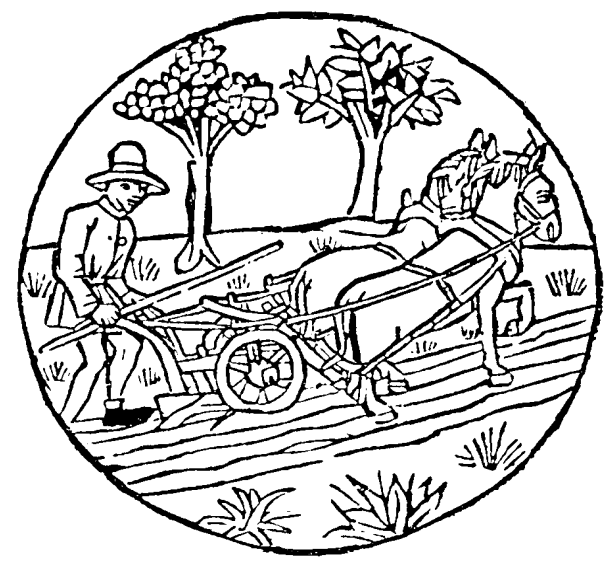

Huhtikuun askareita Johannes von Gmundenin kalenterissa: Kylvetään siemenet.
7 dellisessä luvussa pantiin järjestykseen kuukausia ja vuosia. Tässä luvussa kerrotaan lyhemmistä jaksoista eli päivistä, tunneista, minuuteista ja sekunneista, kellojen kehityksestä ja sellaisista nykyajan keksinnöistä kuin kesäaika ja karkaussekunti. Näistä aiheista käytetään yhteistä nimitystä ajanmittaus.

\section{Aamusta iltaan vai keskipäivästä keskiyöhön}

Vuorokausi on helpoiten näkyvä luonnon jakso. Auringon kierto maapallon taivaan ympäri säätelee kaikkien elävien olentojen toimintaa. Luontokunta herää aamulla päivän töihin, lopettaa ne illalla auringon laskettua ja viettää pimeän ajan yleensä unessa.

Päivä on aivan viime aikoihin asti ollut myös ajanmittauksen perustana. Päivää lyhemmät ajanjaksot määriteltiin vuorokauden osina, koska luonnosta ei tunnettu mitään lyhempää, säännöllisesti toistuvaa jaksoa.

Nykyihmisen vuorokausi vaihtuu keskiyöllä. Tämä on vain sopimuskysymys, sillä vuorokaudessa on muitakin sopivia aloituskohtia. Vuorokausi voisi alkaa vaikkapa auringon noustessa, auringon ollessa korkeimmillaan taivaalla tai auringon laskiessa.

Kaikkia näitä vuorokauden alkukohtia on käytetty eri kulttuurien piirissä. Vanhin käytäntö tuhansien vuosien takaa oli päivän alkaminen aamulla. Egyptiläisten vuorokausi alkoi päivän valjetessa, joko aamuhämärän väistyessä tai auringonnousun hetkellä. Babylonialaiset taas aloittivat vuorokautensa illalla auringon laskiessa. Babylonialaisten käytäntö periytyi $\mathrm{mm}$. juutalaisille, jotka edelleenkin aloittavat vuorokautensa illasta.

Babylonialaisten ja juutalaisten käytäntö perustui siihen, että heillä uusi kuukausi alkoi silloin, kun kapea kuunsirppi ilmestyi uudenkuun jälkeen ensi kertaa taivaalle. Koska uusi sirppi näkyy aina auringon 


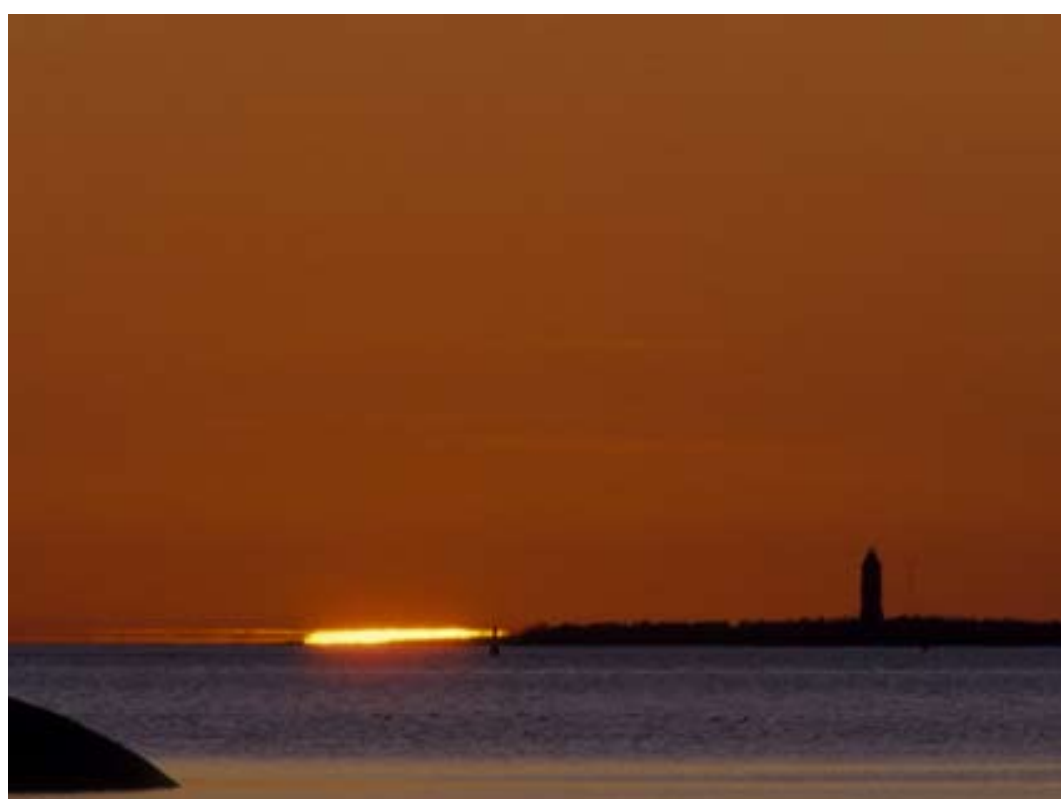

Auringonlasku aloittaa esimerkiksi islamilaisilla ja juutalaisilla uuden vuorokauden. (Kuva Pekka Parviainen, www.polarimage.fi)

vasemmalla puolella, se nähdään iltataivaalla heti auringon laskettua. Koska uusi kuukausi alkoi illan tullessa, oli luonnollista, että myös kuukauden ensimmäinen vuorokausi alkoi samalla hetkellä.

Tapa aloittaa vuorokausi keskiyöllä on ilmeisesti peräisin kreikkalaiselta tähtitieteilijältä Hipparkhokselta, joka eli toisella vuosisadalla ennen Kristusta. Hän ehkä halusi saada kaikki yhden valoisan jakson tapahtumat kuulumaan samaan vuorokauteen, ja siksi vuorokauden vaihtumiskohdaksi sopi parhaiten lepojakson keskikohta, keskiyö.

Hipparkhoksen ehdotus otettiin käyttöön Roomassa, ja sitä tietä tapa yleistyi Eurooppaan ja nykyihmisten käyttöön.

\section{Tuntien synty}

Päivän jako tunteihin on myös hyvin vanhaa perua. Babylonialaiset jakoivat 4000 vuotta sitten koko vuorokautensa (auringonlaskusta seuraavaan auringonlaskuun) kahteentoista osaan. Egyptiläiset jakoivat sa- moihin aikoihin päivän valoisan osan kahteentoista tuntiin. Samanlaista jakoa käytettiin Kiinassa, kun taas hindut jakoivat päivän 60 osaan.

Egyptiläisille yö merkitsi aluksi jaksoa, jolloin aika ei edennyt samalla tavalla kuin päivällä. Koska yöllä ei näkynyt aurinkoa liikkumassa taivaalla, voitiin yötä pitää "ajattomana" aikana. Tuohon aikaan koko ajan käsitys oli toisenlainen kuin nykyään. Tämän päivän kodeissa kellot mittaavat samaa aikaa aina ja kaikkialla, ja ajan kuvitellaan soljuvan tasaisesti eteenpäin. Egyptiläisillä ei aluksi ollut mitään muuta kelloa kuin auringon kulku, ja käsitys ajan tasaisesta, jatkuvasta kulumisesta olisi voinut olla heille outo.

Vähitellen egyptiläiset oppivat pitämään aikaa myös yöllä, sillä tähtien kierto taivaankannen poikki ajaa saman asian kuin auringon kierto päivällä. Koska tähtitaivaasta näkyy eri vuodenaikoina eri alueet, etsittiin taivaan kultakin alueelta sopivia kirkkaita tähtiä yöllisiksi viisareiksi. Myös yö ruvettiin jakamaan kahteentoista osaan, ja näin syntyi nykyinen 24-tuntinen vuorokausi. Babylonialaiset siirtyivät egyptiläisen mallin mukaan myös 12-tuntisesta 24-tuntiseen vuorokauteen.

Luku 12 ilmestyi monen kulttuurin piirissä päivän jaoksi. Miksi juuri 12 eikä esimerkiksi 10 tai 7? Syynä on luultavasti se, että kahden pitemmän ajanmittausjakson, vuoden kierron ja kuun kierron, suhde

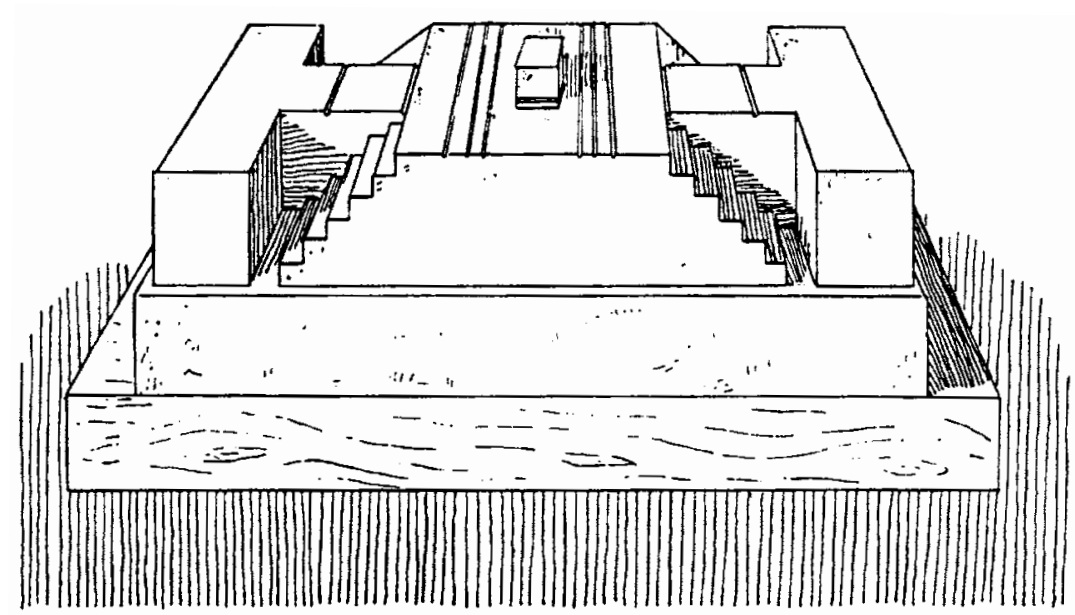

Egyptiläisessä porrasaurinkokellossa ajan kulku näkyy siitä, miten kukin porras on valossa tai varjossa. 
on suunnilleen 12. Vuosi jaettiin kahteentoista kuukauteen, ja siksi oli luonnollista jakaa myös päivä kahteentoista tuntiin.

\section{Luonnolliset tunnit vai tasaustunnit}

Egyptiläisten päivä jaettiin aina tasan kahteentoista tuntiin riippumatta päivän pituudesta. Kesällä päivät olivat pitempiä ja siksi myös tunnit olivat pitempiä. Talvella päivät lyhenivät ja myös tunnit lyhenivät

Yötuntien pituudet vaihtelivat päinvastoin. Kesällä yötunnit olivat lyhyitä, talvella pitkiä.

Ihmiskunta eli tuhansia vuosia aivan tyytyväisenä muuttuvanpituisiin tunteihin. Siirtyminen nykyisiin vakiotunteihin tapahtui vasta keskiajan lopulla, 1300-1400-luvuilla.

Egyptin leveysasteilla ei päivien pituudessa vuoden eri aikoina ole tietenkään niin suuria eroja kuin meillä Pohjolassa. Kesällä valoisan ajan pituus saattaa Välimeren maissa olla 14 tuntia, talvella 10. Siksi tuntien pituudenvaihtelulla ei ollut suurta merkitystä.

Suomen leveysasteilla ero kesän ja talven välillä on paljon suurem-

\section{Raamatun päivät ja hetket}

ahdentuhannen vuoden takaiset aikamitat näkyvät yhä Raamatun teksteissä. "Päivä" tarkoittaa yleensä Raamatussa samaa kuin nykyään eli aikaa auringon noususta sen laskuun. Mutta jos päivällä tarkoitetaan koko vuorokautta, sellainen päivä alkoi juutalaisten tapaan illalla auringon laskiessa ja päättyi seuraavana iltana auringonlaskuun.

Sekä päivä (valoisa aika) että yö jaettiin kahteentoista hetkeen (tai uudemmissa raamatunkäännöksissä tuntiin). Hetkiä ruvettiin laskemaan auringonnoususta, joka sattui nykyisissä aikamitoissa noin kello 6. Päivän kolmas hetki oli silloin kello 9:n tienoilla, kuudes hetki keskipäivällä ja 12. hetki auringon laskiessa.

Kun siis Markuksen evankeliumi kertoo, miten "kuudennesta tunnista alkaen tuli pimeä yli koko maan, ja sitä kesti yhdeksänteen tuntiin asti", tämä merkitsee, että pimeys kesti noin klo 12:sta noin klo 15:een.

Uusimmassa raamatunkäännöksessä (1992) jakeen alkuun onkin lisätty selittävä sana: "Keskipäivällä, kuudennen tunnin aikaan, tuli pimeys koko maan ylle, ja sitä kesti yhdeksänteen tuntiin saakka." pi. Mutta menneinä vuosituhansina oli Suomen saloilla vaeltelevilla metsämiehillä varmasti muuta ajateltavaa kuin päivän jako pienempiin osiin, ja keskiajalla aikaa opittiin jo mittaamaan yksinkertaisten kellojen avulla.

Ainoat hetket vuodessa, jolloin koko maapallolla tunnit ovat yöllä ja päivällä yhtä pitkät, ovat syys- ja kevätpäiväntasausten aikaan eli syyskuun lopulla ja maaliskuun lopulla. Silloin sekä päivä- että yötunnin pituus on 60 nykyminuuttia.

Kreikkalainen Hipparkhos, jota saamme kiittää siitä, että vuorokausi alkaa keskiyöstä, ehdotti yli 2000 vuotta sitten, että otettaisiin käyttöön tasapituiset tunnit. Vuoden mittaan vaihtuvat "luonnolliset" tunnit korvattaisiin aina yhtä pitkillä "tasaustunneilla". Muutosta ei voitu hetikään toteuttaa, kun käytössä ei ollut mitään tapaa tasapitkien tuntien mittaamiseksi. Aikaa ehti vierähtää 1500 vuotta, ennen kuin ehdotus hyväksyttiin, ja muutos edellytti uudentyyppisten kellojen keksimistä.

\section{Aurinkokellosta heilurikelloon}

Auringon kulku taivaalla (ja tähtien kulku yöllä) on se luonnollinen viisari, joka entisajan ihmisille näytti ajan kulun. Ensimmäinen hetki alkoi auringon noustessa. Kun aurinko oli korkeimmillaan, elettiin kuudetta hetkeä; kun se laski, oli jo kahdestoista hetki.

Suurempaan tarkkuuteen päästään, kun pannaan keppi pystyyn maahan ja seurataan kepin varjon kulkua. Jos kepin ympärille piirretään ympyrä, joka jaetaan 24 osaan, saadaan aurinkokello.

Välimeren maissa oli aurinkokelloja käytössä jo vuoden 1500 paikkeilla ennen Kristusta. Mutta aurinkokello toimi vain päiväsaikaan, ja siksi yötä varten tarvittiin muunlaisia ajanmittaajia.

Sellaisia löytyi ainakin kolmea tyyppiä. Vesikello perustui veden valumiseen pienestä reiästä, ja säiliössä aleneva tai ylenevä vedenpinta mittasi melko tasaista aikaa.

Toinen kello perustui hiekan valumiseen. Se oli varmaankin tarpeen kuivissa autiomaissa, missä jokainen vesitippa oli arvokas eikä vettä riittänyt valutettavaksi. Hieno hiekka valuu reiästä melkein yhtä tasaisesti kuin vesi. Hiekkakelloja sanotaan nykyään tiimalaseiksi, ja niitä löytyy edelleen vaikkapa lahjatavarakaupoista.

Kolmas kellotyyppi, tulikello, perustui öljyn tai kynttilän palamiseen. 
Vesikello on astia, josta vesi valuu ulos pienestä reiästä. Vedenpinnan alenemisesta luetaan ajan kulku. Tulikellossa (oikealla) öljynpinta taas näyttää aikaa.
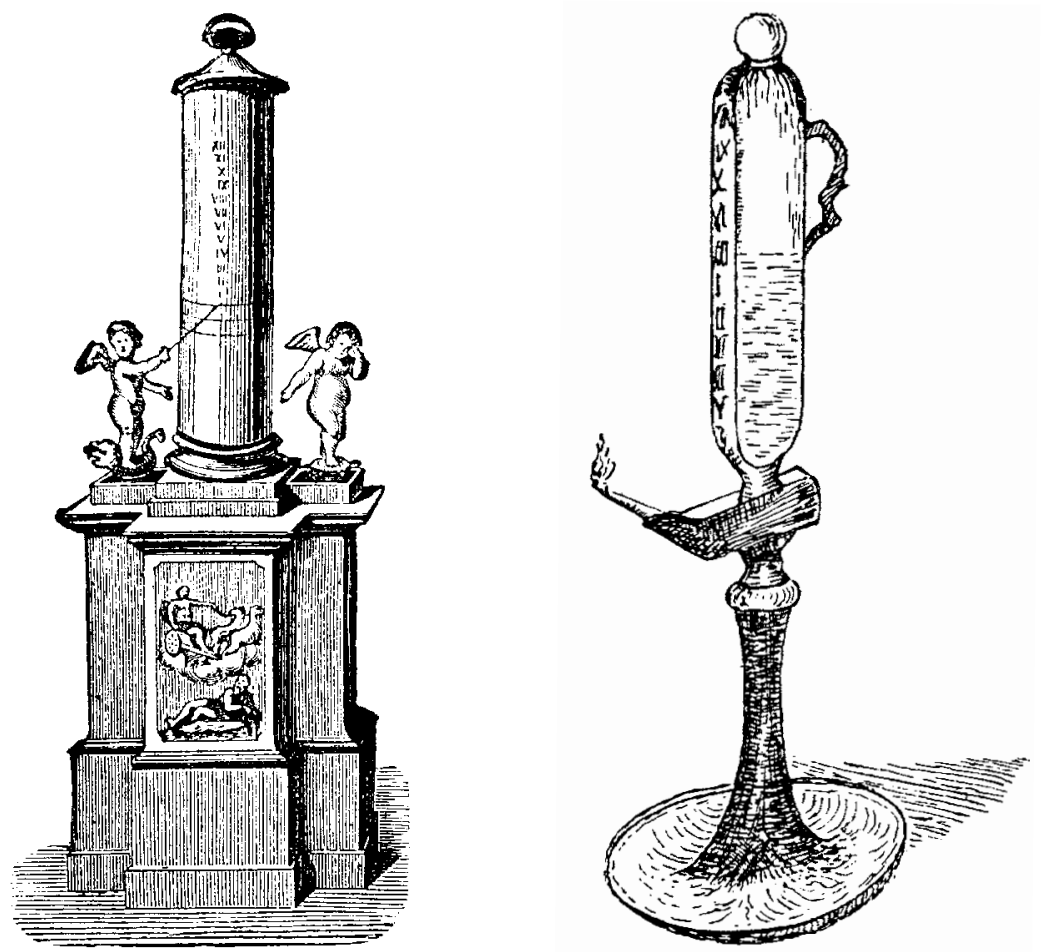

Öljyn väheneminen öljylampusta tai kynttilän lyheneminen mittasi tuntien kulkua.

Seuraavat edistysaskeleet kellojen kehityksessä otettiin 1200-1300-luvuilla. Tuolloin alkoi mekaanisten, edestakaiseen liikkeeseen perustuvien kellojen voittokulku.

Ensimmäiset mekaaniset kellot kehitettiin Euroopassa 1200-luvulla. Käyttövoimansa ne saivat painoista, joita maapallon vetovoima veti alaspäin. Ajan mittaaminen perustui metallitangon heilahteluun. Tanko oli vaakasuorassa, ja sen päissä oli pienet painot. Kun tällainen tanko heilahtelee edestakaisin, heilahdusaika pysyy melko hyvin vakiona.

Keskiajan mekaaniset kellot saattoivat edistää tai jätättää puolikin tuntia vuorokaudessa. Mutta ne asetettiin aina uudestaan oikeaan aikaan auringon avulla.
Kelloissa oli alkuun vain yksi osoitin, joka mittasi tuntien kulkua. Kellotaulu jaettiin aluksi 24 osaan, joten viisari kiersi kertaalleen kellotaulun ympäri vuorokaudessa.

Mekaaniset kellot olivat alkuun ylellisyyskapineita, ja tavallinen kansa luotti edelleen aurinkoon, öljylamppuihin tai kynttilöihin. Kelloja asennettiin varsinkin kirkontorneihin, raatihuoneitten seinille tai muihin arvokkaisiin rakennuksiin. Vanhimmat tunnetut tornikellot ilmestyivät eri puolille Eurooppaa 1270-1330-luvuilla. Esimerkiksi Milanon tornikello oli rakennettu vuonna 1335, ja siinä vuorokausi alkoi illalla auringon laskiessa.

Kellojen kokoa voitiin tekniikan kehittyessä pienentää, ja aikaisemmista pöydänkokoisista koneistoista voitiin 1400-luvun lopulla siirtyä jopa mukanakuljetettaviin kelloihin.

Vuoden 1500 paikkeilla korvattiin 24-tuntinen kellotaulu nykyisellä

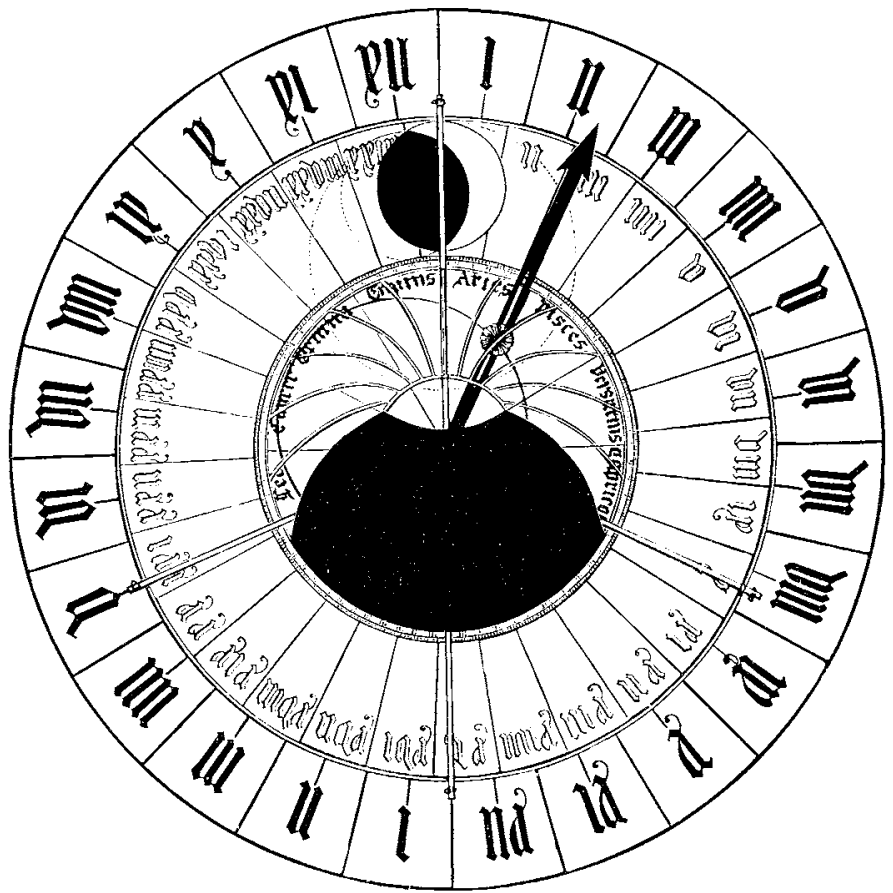

Bourgesin katedraalin kalenterikellossa on kellotaulu jaettu 24 osaan ja aikaa näyttää yksi viisari. 
12-tuntisella, mutta kellossa oli edelleen vain yksi viisari.

Kellojen tarkkuus parantui 1600-luvulla. Mekaanisissa kelloissa keksittiin vaakatangon tilalle liipotin ja spiraalijousi, joiden heilahtelu pysyy vakiopituisena paljon paremmin kuin vaakatankojen.

Liipotinkellon rinnalle kehittyi heilurikello, jossa tarkan jakson antaa pitkä heiluri. Jo Galileo Galilei oli 1500-luvun lopulla osoittanut, että heilurin heilahdusaika pysyy vakiona ja riippuu vain heilurin varren pituudesta. Heilurikelloja ei voinut kylläkään siirrellä, jottei varren heilahtelu olisi mennyt sekaisin, mutta paikallaan pysyviin kelloihin saatiin uutta tarkkuutta.

Jo 1500-luvun lopulla kelloissa kokeiltiin minuutti- ja sekuntiviisareita. Yleiseen käyttöön minuuttiviisari tuli vuoden 1680 paikkeilla ja sekuntiviisari hieman myöhemmin.

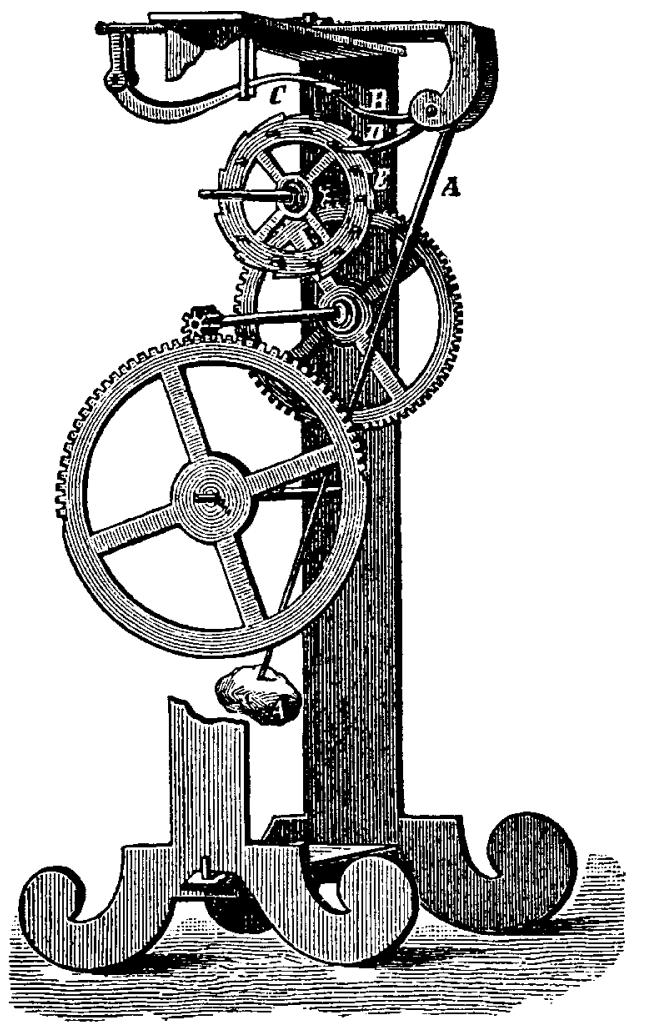

Galilein heilurikello.

\section{Minuutti, sekunti, tertti, kvartti...}

Vaikka minuutteja ja sekunteja opittiin kelloilla mittaamaan 1600-luvulla, niiden nimet ja merkitykset olivat syntyneet jo lähes 2000 vuotta aikaisemmin.

Tunnin jako-osia tarvittiin tuohon aikaan tähtitieteessä, joka käytti taivaankannen mittaamiseen samoja yksiköitä kuin ajan mittaamiseen. Koska aurinko tekee taivaalla täyden kierroksen 24 tunnissa, oli taivaan ympärysmitta sama 24 tuntia. Kahden tähden välimatkaksi taivaalla voitiin mitata vaikkapa yksi tunti tai vain pieni osa tuntia.

Nykyään ympyrän kulmia ja kaaria mitataan asteina, siten että täysi ympyrä on 360 astetta. Vaikka tähtitieteilijät mittaavat suuren osan taivaan kulmista asteina, osa mitataan edelleen aikamitoissa. Yksi tunti taivaalla vastaa viittätoista astetta.

Tähtitieteen tarpeita varten jaettiin tunti kuuteenkymmeneen osaan. Koska taivaalta voidaan mitata vielä tarkempia kulmia, jaettiin yksi tällainen osa edelleen kuutenkymmeneen osaan, yksi sellainen taas kuuteenkymmeneen ja niin edelleen. Luku 60 saatiin babylonialaisilta, joiden numerojärjestelmässä oli kantalukuna 60 eikä 10 kuten meillä nykyään.

Babylonialaisen jaon toi länsimaihin samainen Hipparkhos, joka on mainittu jo pari kertaa aikaisemmin. Hän laati ensimmäisen kunnollisen tähtiluettelon ja tähtikartan ja käytti niissä tunnin pienempiä osia.

Vakiintuneet nimet osille saatiin myöhemmin latinasta. Pars minuta tarkoittaa pientä osaa, ja siitä tuli meille minuutti. Pars secunda tarkoittaa toista osaa, ja siitä saatiin sekunti. Mutta jako ei päättynyt tähän. Pars tertia oli kolmas osa eli sekunnin kuudeskymmenesosa. Jos se olisi edelleen käytössä, sitä sanottaisiin varmaan tertiksi ja suomalaiset kielimiehet saisivat kiistellä, kirjoitetaanko se tertti vai terti. Seuraava osa oli kvartti (1/3600 sekuntia), seuraava kvintti (1/216000 sekuntia) ja niin edelleen.

Minuutit, sekunnit ja tertit pysyivät tähtitieteilijöiden ja matemaatikoiden käytössä, mutta aikamittaukseen niitä ei vielä tarvittu. Kopernikus käytti vielä 1600-luvun alussa terttejä omissa kirjoituksissaan, mutta sen jälkeen sekuntia pienemmät osaset jäivät pois. Kun pienempiä aika- tai kulmamittoja myöhemmin on käytetty, on ruvettu puhumaan sekunnin desimaaliosista eli kymmenes-, sadas-, tuhannes- jne osista.

Jos tertit ja kvartit olisivat säilyneet käytössä, voisimme urheiluselos- 
tuksista lukea, miten Kimi Räikkönen ajoi 4 kvarttia nopeamman kierrosajan kuin Lewis Hamilton tai miten sadan metrin pikajuoksun uusi maailmanennätys kirjataan numeroin 9 sekuntia 47 terttiä.

\section{Harrisonin kronometri nro 4}

Ehkä tunnetuin yksittäinen kello ajanmittauksen historian varrelta on englantilaisen John Harrisonin "kronometri numero 4".

Britannian hallitus lupasi 1700-luvun alussa 20000 punnan palkinnon sille, joka kehittää luotettavan menetelmän paikanmääräykseen merellä. Englannin laivoja purjehti jo kaikilla maailman merillä, mutta purjehtiminen oli vaarallista, ellei aluksen paikka ollut tarkasti selvillä.

Laivan kapteenin piti tietää sekä se leveysaste että pituusaste, missä laiva kulloinkin purjehti. Leveysasteen määräminen on helppoa. Se onnistuu, kun mitataan tarkalla kulmamittauskojeella (sekstantilla) auringon ja tähtien korkeus taivaanrannasta.

Myös pituusasteen määrääminen onnistuu tähtien ja auringon avulla, jos vain kapteenilla on tiedossaan tarkka kellonaika. Tässä oli tehtävän

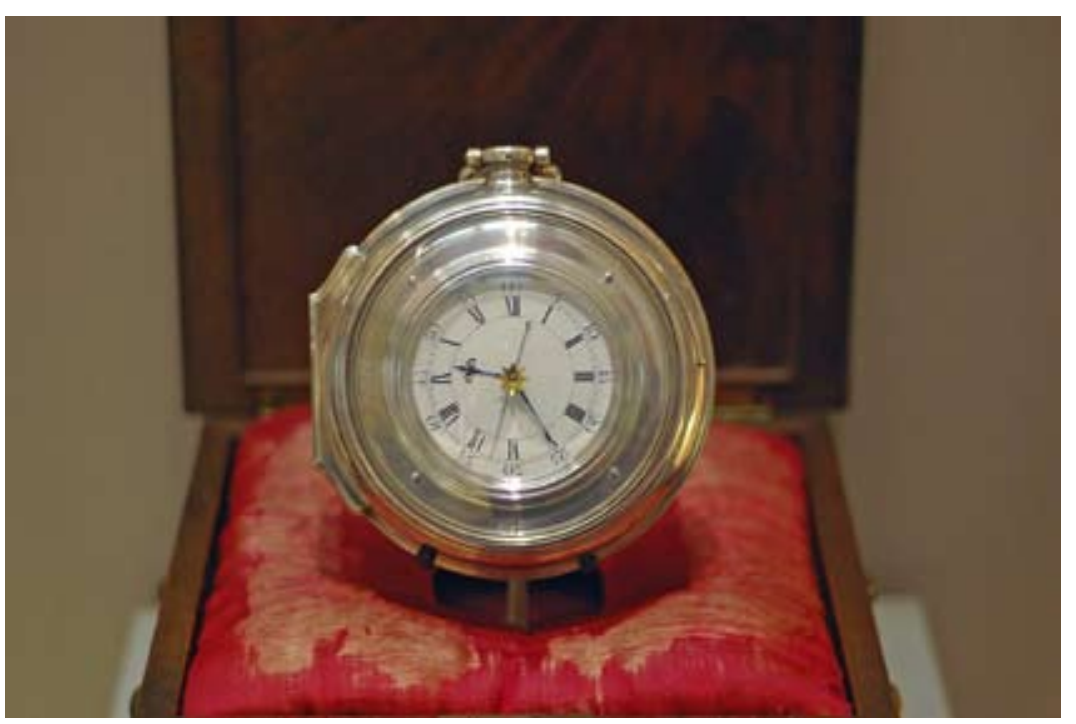

John Harrisonin kuuluisa kronometri 1700-luvulta. (Kuva Racklever at en.wikipedia, licensed under the Creative Commons Attribution 2.5 Generic license) vaikeus. Tuon ajan kellojen käyntitarkkuus oli sitä luokkaa, että vuorokaudessa saattoi virhettä kertyä useita minuutteja. Jos laiva oli ollut matkalla kymmeniä tai satoja päiviä, saattoi kello olla väärässä useita tunteja. Ja pituusasteen määrääminen edellytti, että oikea aika tunnettiin vähintään minuutin tarkkuudella.

John Harrison (1693-1776) oli puuseppä ja itseoppinut kellontekijä, joka 1700-luvulla valmisti toinen toistaan tarkempia kelloja. Viimein hänen neljäs kronometrimallinsa vuodelta 1759 oli tarpeeksi tarkka hallituksen palkinnon saamiseen. Kello vietiin viiden kuukauden merimatkalle, ja sen jälkeen kello näytti vain 54 sekunnin verran virheellistä aikaa.

\section{Aurinko ei ole tarkka kello}

Kun kellot oli saatu käymään sekuntien tarkkuudella, huomattiin, että aurinko ei näytäkään tasaista aikaa. Joinakin aikoina vuodesta aurinko hieman jätättää, joinakin edistää, kun vertailukohtana käytetään tasaisesti kulkevia kelloja.

Auringon epätarkkuus huomattiin keskipäivän hetkistä. Kellot pidet-

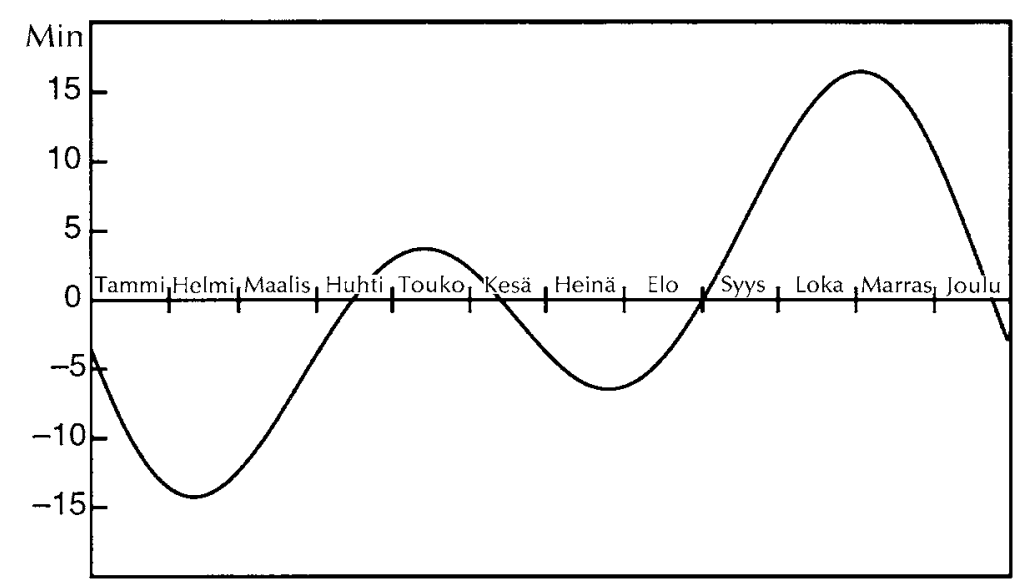

Ajantasaus kertoo, miten auringon näyttämä aika poikkeaa tasaisesta "rannekelloajasta". Aurinkoaika poikkeaa keskiaurinkoajasta enimmillään -14 minuuttia (helmikuussa) ja +16 minuuttia (marraskuussa). Lisäksi poikeamaa tulee siitä, kuinka paljon paikkakunnan keskiaurinkoaika poikkeaa maan vyöhykeajasta. (Piirros mukailtu Tähtitieteen perusteet -kirjasta) 
tiin 1700-luvulla aurinkoajassa siten, että kun aurinko oli korkeimmillaan ja suoraan etelässä, kello oli tasan 12. Mutta kun keskipäivän hetkeä tarkkailtiin ympäri vuoden, huomattiin että aurinko oli välillä etelässä jo neljännestunnin verran ennen kellon näyttämää kahdentoista hetkeä, välillä neljännestunnin jälkeen 12:n.

Sama toistui vuodesta toiseen samoina aikoina. Tähtitieteilijät rupesivat kutsumaan tätä tasaisen ajan ja auringon näyttämän ajan eroa ajantasaukseksi. Edellisen sivun käyrään on piirretty ajantasauksen suuruus eri aikoina vuotta.

Tähtitieteilijät selvittivät, että auringon epätarkkuus johtuu kahdesta eri tekijästä. Yksi on se, että aurinko ei liiku tähtitaivaalla pitkin päiväntasaajaa, vaan pitkin eläinrataa, joka on kallellaan päiväntasaajaan nähden. Tästä johtuu yksi heilahtelu.

Toinen syy on siinä, että maapallon nopeus aurinkoa kiertävällä radalla vaihtelee. Talvella, kun maapallo on lähimpänä aurinkoa, maapallo kulkee radallaan nopeinta vauhtia. Heinäkuun alussa, kauimpana auringosta, vauhti on taas hitainta. Maapallon vaihteleva nopeus heijastuu myös auringon kulkunopeuden muutoksina, kun se kiertää maapallon taivaalla.

\section{Keskiaika}

Kun nyt auringon käynti olikin havaittu epätarkaksi, mihin voitiin sitten kelloja verrata, jotta ne pysyisivät täsmälleen oikeassa? Kyllä tähtitaivaalta piti löytää jokin luonnon oma viisari, joka osoittaisi tasaista aikaa.

Kun sellaista ei ollut, piti sellainen kehittää. Tähtitieteilijät keksivät todellisen auringon tilalle keinoauringon, jota ruvettiin sanomaan keskimääräiseksi auringoksi eli keskiauringoksi. Se teki taivaalla yhden kierroksen vuodessa aivan kuin oikea aurinko, mutta se kulki pitkin taivaan päiväntasaajaa (toisin kuin oikea aurinko) ja täsmälleen vakionopeudella. Tällaisen keskiauringon näyttämää aikaa ruvettiin sanomaan keskiaurinkoajaksi. Se kulki aivan tasaisesti, ja nyt voitiin taas kellot pitää oikeassa vertaamalla niitä keskiaurinkoon. Vertailu ei ollut aivan yhtä helppoa kuin tavallisen auringon kanssa, koska siinä jouduttiin käyttämään hieman matematiikkaa, mutta laskukaavat eivät olleet kovin vaikeita.

Keskiaurinkoajan käyttö levisi vähitellen länsimaissa. Ensimmäisenä siirtyi Sveitsi luonnon aurinkoajasta keskiaurinkoaikaan vuonna 1710, sitten Iso-Britannia 1792 ja esimerkiksi Ranska 1816. Suomessa otettiin keskiaurinkoaika käyttöön 1833, samalla kun almanakan horisontti siirrettiin Turusta Helsinkiin.

Suomalainen almanakka oli ilmoittanut auringon nousut ja laskut vuoteen 1832 asti Turun mukaan. Yliopisto oli edellisen vuosikymmenen lopulla, Turun suuren palon jälkeen, siirtynyt uuteen pääkaupunkiin Helsinkiin. Vuodesta 1833 alkaen noudatettiin almanakoissa Helsingin aikaa, jota voitiin siten pitää Suomen virallisena aikana.

Vuonna 1832 ja sitä aikaisemmissa suomalaisissa almanakoissa auringon nousu- ja laskuaika oli aina yhtä kaukana kello kahdestatoista. Käytössä oli siis todellinen aurinkoaika eikä ajantasausta otettu huomioon. Vuodesta 1833 alkaen käytettiin keskiaurinkoaikaa, jossa keskipäivä oli osan vuotta ennen kello kahtatoista, osan vuotta kahdentoista jälkeen.

Vaikka almanakkojen viralliset ajat ilmoitettiin keskiauringon avulla, jouduttiin syrjäisemmillä seuduilla ja pienemmillä paikkakunnilla edelleen käyttämään vanhaa kunnon aurinkoaikaa. Paikkakunnan silmäätekevät ruuvasivat taskunauriinsa näyttämään kahtatoista, kun aurinko oli etelässä, ja sillä hyvä. Tarkkuus riitti mainiosti sen ajan vaatimuksiin.

\section{Aikavyöhykkeet otetaan käyttöön}

1800-luvun puolivälissä levisi maailmalle kaksi mullistavaa keksintöä: rautatiet ja lennätin. Rautateiden avulla ihmisten ja tavaran liikkuminen paikasta toiseen huomattavasti nopeutui, ja lennättimen avulla voitiin ensimmäisen kerran välittää sanomia paikasta toiseen lähes viiveettä - reaaliajassa, kuten nykyään sanottaisiin.

Lennätinlinjoja ja rautateitä rakennettiin usein käsi kädessä, sillä molemmilla haluttiin ensin yhdistää toisiinsa tärkeimmät kaupungit.

Suomen ensimmäinen rautatie avattiin Helsingistä Hämeenlinnaan 1862. Juna kulki tarkan aikataulun mukaan, ja siksi kaikkien kellojen piti radan varrella näyttää samaa aikaa. Jo vuoden 1864 aikataulussa junien ajat kerrottiin minuutin tarkkuudella. Lähtöajaksi saattoi olla merkittynä 6.9 j.p.p. eli yhdeksän minuuttia yli kuuden jälkeen puolenpäivän (nykykielellä 18.09).

Rautateiden virallisena aikana käytettiin Helsingin paikallisaikaa. Aikaa mitattiin Helsingin yliopiston observatoriossa Tähtitorninmäellä. 


\section{Kiista nollameridiaanista}

Koska maapallo on pyöreä pallo, mikään piste sen pinnalla ei tarjoudu itsestään selväksi nollameridiaanin paikaksi. Sellainen täytyy aina valita.

Ensimmäisen valinnan teki tähtitieteilijä Ptolemaios vuoden $100 \mathrm{jKr}$ paikkeilla. Hän piti maailman läntisimpänä kohtana Kanarian läntisintä saarta Ferroa (espanjaksi Hierroa). Sen takana oli vain merta ja sitten ehkä maailman reuna. Paikkojen pituuspiirit ilmoitettiin Ferrosta itään.

Ferron asema vahvistettiin myös Ranskassa 1500 vuotta myöhemmin. Kardinaali Richelieu määräsi 1634, että ranskalaisissa kartoissa pituuspiirit määrätään Ferron suhteen, joka sijaitsee runsaat 20 astetta Pariisista länteen. Kartat käyttivät aluksi Ferroa lähtökohtana, mutta siirtyivät myöhemmin laskemaan pituuspiirejä Pariisin observatorion suhteen.

Suomen Valtiokalenteri oli 1800-luvun puolivälissä vielä Ferron kannalla: Helsingin observatorion sijainniksi ilmoitettiin 42³7,5' itään Ferron meridiaanista tai $5^{\circ} 21,9^{\prime}$ länteen Pulkovan observatoriosta. Pulkovassa Pietarin lähellä sijaitsi Venäjän vastavalmistunut pääobservatorio.

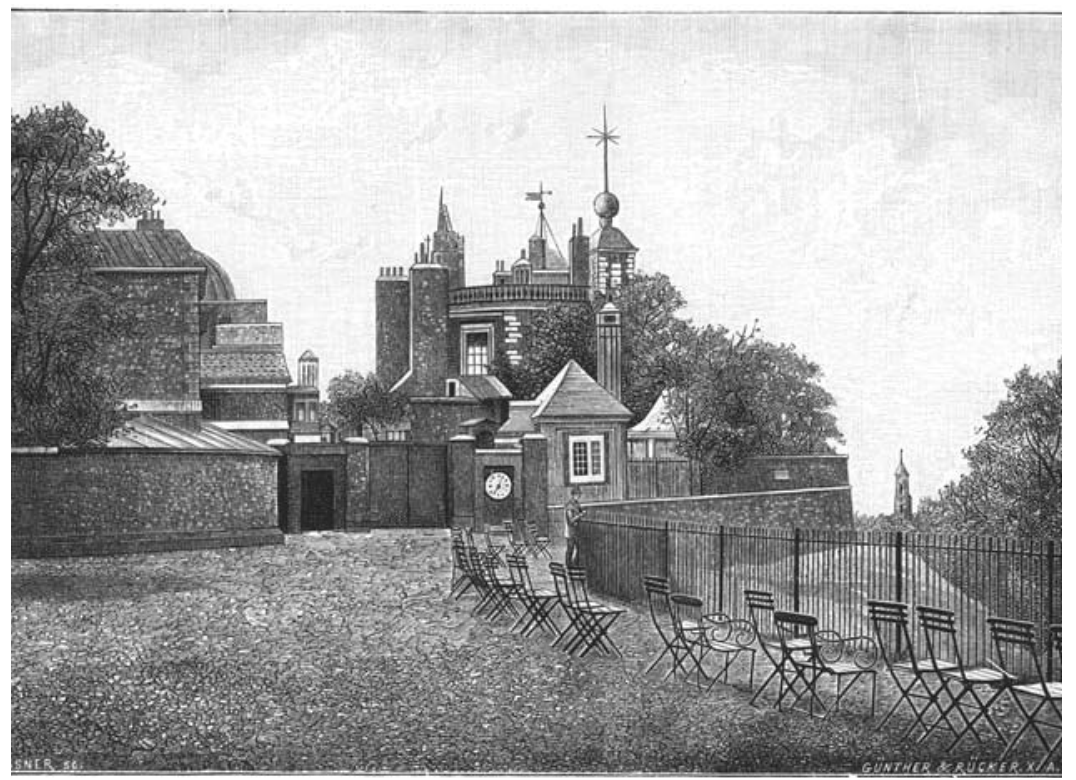

Greenwichin kuninkaallinen observatorio 1800-luvun puolivälissä. Viereisellä sivulla observatorio nykypäivän asussa. Paikalla parveilee jatkuvasti turisteja.
Englanti perusti 1600-luvulla Lontoon lähelle Greenwichin observatorion, joka rupesi 1700-luvulla julkaisemaan merenkulkijoiden tarvitsemaa kalenteria nimeltään Nautical Almanac. Koska Englannilla oli oma hieno tähtitorninsa Lontoossa, ei englantilaisten luonto antanut myöten ruveta käyttämään Pariisin tai Ferron suhteen mitattuja paikkoja. Ei, kaikki ajanmääritykset, paikanmääritykset ja merikartat laadittiin Greenwichin observatorion suhteen.

Washingtonin kokous 1884 joutui tekemään ratkaisun Pariisin ja Greenwichin välillä. Vaaka kallistui englantilaisten eduksi varsinkin sen takia, että maailman merikartoista yli 70 prosenttia oli laadittu Greenwichin meridiaanin suhteen. Näihin karttoihin oli helppo piirrellä aikavyöhykkeitä 15 asteen välein.

Washingtonissa tehty päätös oli kova kolaus ranskalaisille. Sikäläiset almanakat ja merikartat laskivat pituuspiirinsä Pariisin suhteen vielä pitkälle 1900-luvulle, ennen kuin ranskalaisetkin lopulta alistuivat kansainväliseen päätökseen.

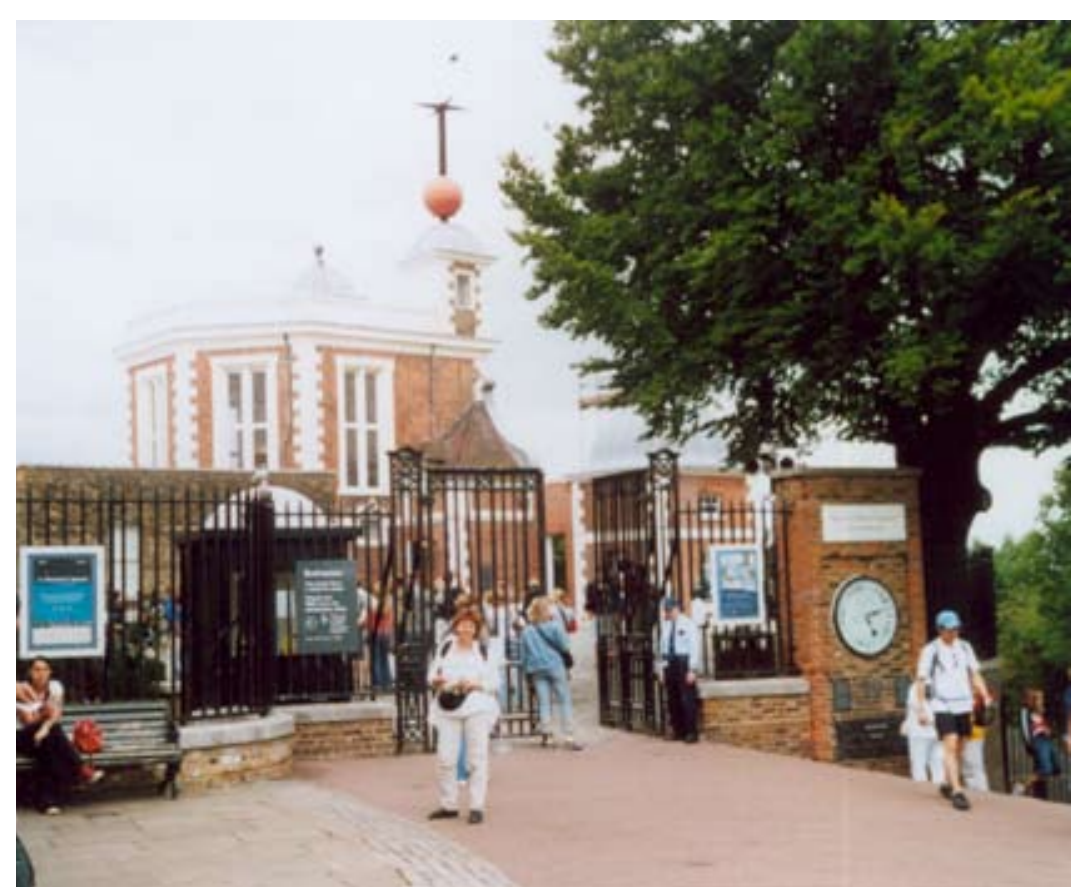




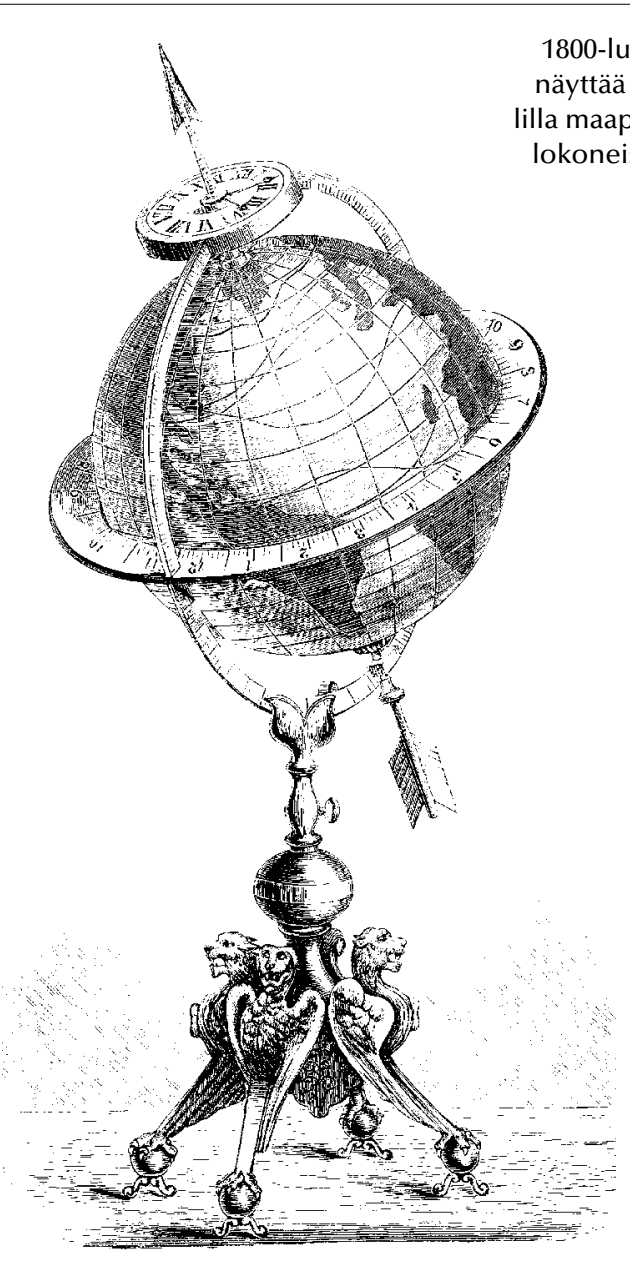

\section{Suomen aikavyöhyke}

Greenwichissä oli siis nollameridiaani. Siitä 15 astetta itään eli Ruotsin ja Keski-Euroopan halki kulkee seuraava perusviiva, jonka läheisyydessä noudatetaan Keski-Euroopan aikaa. Jälleen 15 astetta idempänä on 30 . itäinen pituuspiiri, joka määrittelee Itä-Euroopan ajan. Tämä pituuspiiri kulkee myös Suomen poikki, joten Suomi elää Itä-Euroopan ajassa tunnin edellä Keski-Euroopan aikaa ja kaksi tuntia edellä Greenwichin aikaa.
Suomi ei suinkaan siirtynyt omaan aikavyöhykkeeseensä heti Washingtonin päätöksen jälkeen. Täällä elettiin vielä paikallisaikoja. Valtiopäivät anoivat vuonna 1888 Venäjän keisarilta, että koko Suomessa siirryttäisiin käyttämään yhtenäistä aikaa, joka olisi Helsingin paikallisaika. Keisari ei antanut pyydettyä määräystä, vaan totesi, että kaikilla Suomen rautateillä tuli edelleen noudattaa Helsingin aikaa.

Vaikka keisari ei yhtenäistä aikaa määrännytkään, levisi Helsingin aika yhteyksien parantuessa vähitellen myös syrjäseuduille, ja valtiopäivien tahto toteutui luonnostaan.

Kun tultiin 1900-luvulle ja yhteydet ulkomaille parantuivat, huomattiin Suomessa, että suurin osa Eurooppaa oli jo siirtynyt vyöhykeaikaan. Vastaan pyristelivät enää Ranska (tietysti!), Alankomaat, Portugali, Kreikka ja Venäjä.

Suomen itsenäistyttyä 1917 voitiin lopulta tehdä aikapäätös ilman keisarin määräyksiä. Suomen Maantieteellinen Seura teki esityksen, että Suomi siirtyisi noudattamaan Itä-Euroopan vyöhykeaikaa. Valtioneuvosto päätti, että muutos tehdään vuoden 1921 vappuyönä. Koska Helsingin paikallisaika eroaa 30. itäisen pituuspiirin ajasta runsaat 20 minuuttia, siirrettiin vappuyönä kello 24 kaikkien suomalaiskellojen viisareita 20 minuuttia 10,9 sekuntia eteenpäin. Näin Suomen historiasta jäi puuttumaan 1.5.1921 aikaväli $0.00-0.20$ ja vapun juhlinta jäi 20 minuuttia normaalivuosia lyhemmäksi.

Kolmaskymmenes itäinen pituuspiiri, joka määrittelee Itä-Euroopan ajan, alkaa pohjoisnavalta, kulkee Norjan Huippuvuorten ohi ja lävistää Suomi-neidon lantiot Lieksan kaupungin kohdalla. Samalla aikavyöhykkeellä Suomen kanssa ovat nykyään Baltian maat Viro, Latvia ja Liettua ja Etelä-Euroopassa mm. Kreikka ja Turkki. Afrikan puolella Suomen aikaa noudattavat mm. Egypti, Sambia ja Etelä-Afrikka. Kolmaskymmenes pituuspiiri päätyy Etelämantereelle Prinsessa Ragnhildin rannikolle jälleen norjalaisen tutkimusaseman lähelle.

Maapallon maista lähes kaikki ovat valinneet viralliseksi ajakseen lähimmän vyöhykeajan. Aasiasta löytyy muutamia valtioita, jotka noudattavat omia, tasatunnista poikkeavia aikojaan. Näistä suurin on Intia, joka elää viisi ja puoli tuntia Greenwichin ajan edellä.

Suurikokoisissa valtioissa on käytössä useita aikavyöhykkeitä. Yhdysvalloissa on neljän mannerajan lisäksi vielä omat aikavyöhykkeet Alaskassa ja Havaijilla, ja Venäjällä on vuodesta 2010 alkaen yhdeksän 


\section{Mitä aikaa maapallon eri valtiot noudattavat}

aulukossa on lueteltuna runsaat 180 maapallon valtiota tai aluetta ja niiden normaaliaika verrattuna Suomen normaaliaikaan (eli talviaikaan). Esimerkiksi +2 kertoo, että kyseisessä maassa kello on 14, kun kello on Suomessa 12. Kesäaika on pohjoisella pallonpuoliskolla yleensä maaliskuun lopulta lokakuun lopulle, eteläisellä pallonpuoliskolla lokakuusta helmi- tai maaliskuuhun. Eteläisen pallonpuoliskon todellisia aikaeroja laskettaessa on otettava huomioon, että siellä on usein voimassa kesäaika, kun meillä on talviaika. Siksi aikaero esimerkiksi itäisen Australian ja Suomen välillä ei ole juuri koskaan taulukossa mainittu $+8 \mathrm{~h}$, vaan meidän kesämme aikana se on $+7 \mathrm{~h}$ ja meidän talvemme aikana $+9 \mathrm{~h}$. Tiedot ovat voimassa vuoden 2013 alussa ja niihin saattaa tulla muutoksia. (Taulukko perustuu Risto O. Nykäsen tietoihin.)

$\begin{array}{lrll}\text { Valtio } & \text { Aikaero } & & \text { Mahdollinen kesäaika } \\ \text { Afganistan } & +2.30 & \text { ei } \\ \text { Alankomaat } & -1 & \text { maalisk.-lokak. } \\ \text { Albania } & -1 & \text { maalisk.-lokak. } \\ \text { Algeria } & -1 & \text { ei } \\ \text { Andorra } & -1 & \text { maalisk.-lokak. } \\ \text { Angola } & -1 & \text { ei } \\ \text { Anguilla } & -6 & \text { ei } \\ \text { Arabiemiirikunnat } & +2 & \text { ei } \\ \text { Argentiina } & -5 & \text { ei } \\ \text { Armenia } & +2 & \text { ei } \\ \text { Australia } & +6 /+8 & \\ \quad \text { Länsi-Australia } & +6 & \text { ei } \\ \text { Etelä-Austr. ja Pohjois-Terr. } & +7.30 & \text { lokak.-huhtik./ei } \\ \quad \text { Muu Australia } & +8 & \text { lokak.-huhtik./ei } \\ \text { Azerbaidžan } & +2 & \text { maalisk.-lokak. } \\ & & \\ \text { Bahama } & -7 & \text { maalisk.-marrask. } \\ \text { Bahrain } & +1 & \text { ei } \\ \text { Bangladesh } & +4 & \text { ei } \\ \text { Belgia } & -1 & \text { maalisk.-lokak. } \\ \text { Belize } & -8 & \text { ei } \\ \text { Bermuda } & -6 & \text { maalisk.-marrask. } \\ \text { Bhutan } & +4 & \text { ei } \\ & & \end{array}$

Valtio

Bolivia

Bosnia ja Hertsegovina

Botswana

Brasilia

Fernando de Noronha

Itä-Brasilia

Mato Grosso, Amazonas, Acre

Brunei

Bulgaria

Burkina Faso

Burundi

Chile

Pääsiäissaari

Costa Rica

Djibouti

Dominikaaninen tasavalta

Ecuador

Galapagos-saaret

Egypti

El Salvador

Eritrea

Espanja

Kanarian saaret

Etelä-Afrikka

Etelä-Sudan

Etiopia

Fidži

Filippiinit

Färsaaret

Gabon

Gambia

Georgia

Ghana

Gibraltar

Grenada

Grönlanti
Aikaero

0

$-4 /-6$

-4
-5

$-6$

+6
0

-2
0

maalisk.-lokak maalisk.-lokak.

ei

ei

lokak.-tammik

ei

maalisk.-lokak.

ei
ei
ei
ei
maalisk.-lokak.
ei

maalisk.-lokak. 


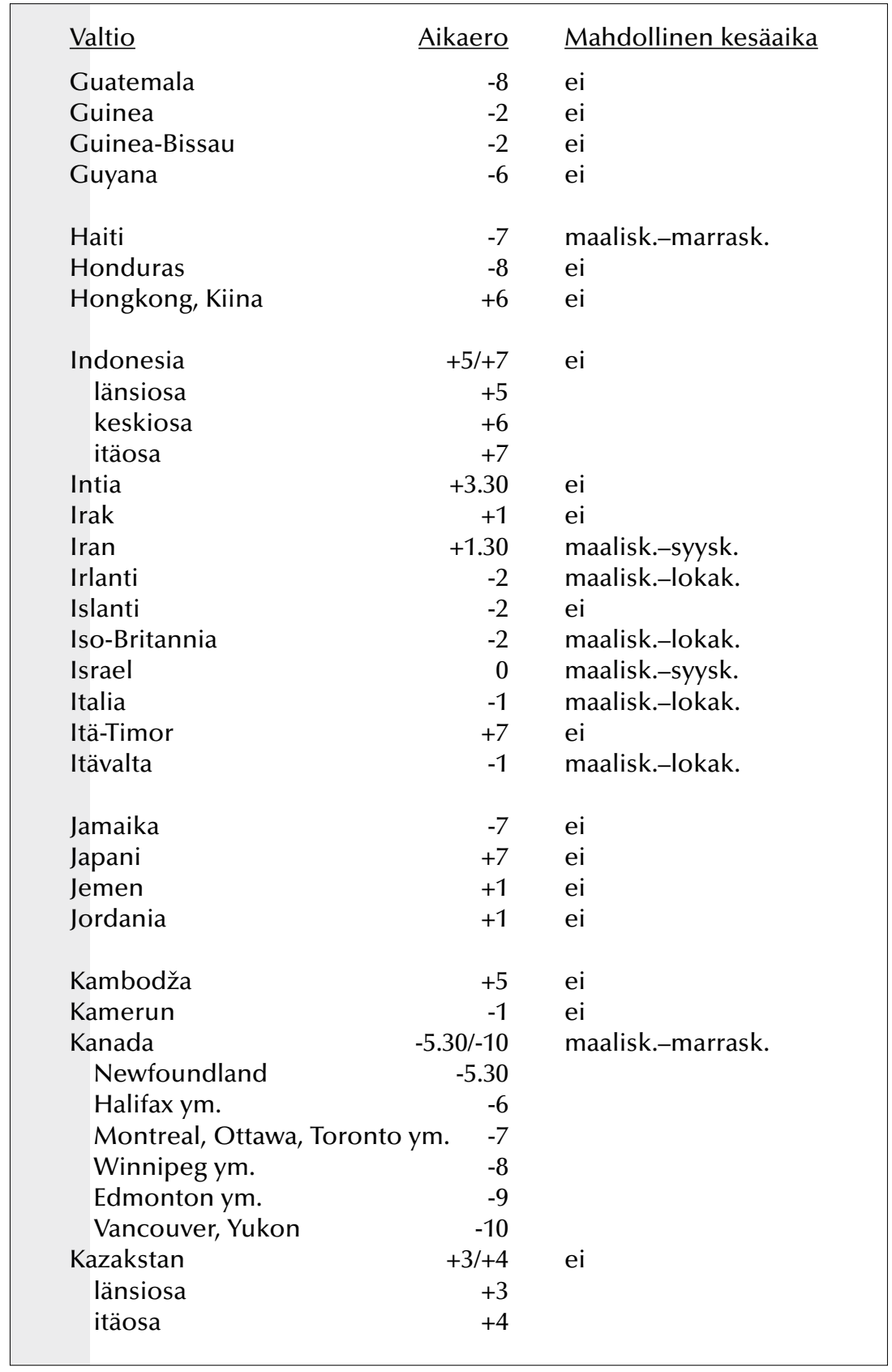

\begin{tabular}{|c|c|c|}
\hline Valtio & Aikaero & Mahdollinen kesäaika \\
\hline Kenia & +1 & ei \\
\hline Keski-Afrikan tasavalta & -1 & ei \\
\hline Kiina & +6 & ei \\
\hline Kirgisia & +4 & ei \\
\hline Kolumbia & -7 & ei \\
\hline Kongon dem. tasavalta & $-1 / 0$ & ei \\
\hline itäosa & 0 & \\
\hline länsiosa, mm. Kinshasa & -1 & \\
\hline Kongon tasavalta & -1 & ei \\
\hline Korean kansantv. (Pohj.-Korea) & +7 & ei \\
\hline Korean tasav. (Etelä-Korea) & +7 & ei \\
\hline Kreikka & 0 & maalisk.-lokak. \\
\hline Kroatia & -1 & maalisk.-lokak. \\
\hline Kuuba & -7 & maalisk.-marrask. \\
\hline Kuwait & +1 & ei \\
\hline Kypros & 0 & maalisk.-lokak. \\
\hline Laos & +5 & ei \\
\hline Latvia & 0 & maalisk.-lokak. \\
\hline Lesotho & 0 & ei \\
\hline Libanon & 0 & maalisk.-lokak. \\
\hline Liberia & -2 & ei \\
\hline Libya & -1 & maalisk.-lokak. \\
\hline Liechtenstein & -1 & maalisk.-lokak. \\
\hline Liettua & 0 & maalisk.-lokak. \\
\hline Luxemburg & -1 & maalisk.-lokak. \\
\hline Madagaskar & +1 & ei \\
\hline Makedonia & -1 & maalisk.-lokak. \\
\hline Malawi & 0 & ei \\
\hline Malediivit & +3 & ei \\
\hline Malesia & +6 & ei \\
\hline Mali & -2 & ei \\
\hline Malta & -1 & maalisk.-lokak. \\
\hline Marokko & -2 & huhtik.-syysk. \\
\hline Meksiko & $-8 /-10$ & huhtik.-lokak. \\
\hline Quintana Roo & -8 & \\
\hline keskiosa, mm. Mexico City & -8 & \\
\hline länsiosa & -9 & \\
\hline Tijuana, Mexicali & -10 & maalisk.-marrask. \\
\hline Moldova & 0 & maalisk.-lokak. \\
\hline
\end{tabular}




\begin{tabular}{|c|c|c|}
\hline Valtio & Aikaero & Mahdollinen kesäaika \\
\hline Monaco & -1 & maalisk.-lokak. \\
\hline Mongolia & +6 & ei \\
\hline Montenegro & -1 & maalisk.-lokak. \\
\hline Mosambik & 0 & ei \\
\hline Myanmar & +4.30 & ei \\
\hline Namibia & -1 & syysk.-huhtik. \\
\hline Nauru & +10 & ei \\
\hline Nepal & +3.45 & ei \\
\hline Nicaragua & -8 & ei \\
\hline Niger & -1 & ei \\
\hline Nigeria & -1 & ei \\
\hline Norja & -1 & maalisk.-lokak. \\
\hline Norsunluurannikko & -2 & ei \\
\hline Oman & +2 & ei \\
\hline Pakistan & +3 & ei \\
\hline Panama & -7 & ei \\
\hline Papua-Uusi-Guinea & +8 & ei \\
\hline Paraguay & -6 & lokak.-maalisk. \\
\hline Peru & -7 & ei \\
\hline Portugali & -2 & maalisk.-lokak. \\
\hline Madeira & -2 & maalisk.-lokak. \\
\hline Azorit & -3 & maalisk.-lokak. \\
\hline Puerto Rico & -6 & ei \\
\hline Puola & -1 & maalisk.-lokak. \\
\hline Päiväntasaajan Guinea & -1 & ei \\
\hline Qatar & +1 & ei \\
\hline Ranska & -1 & maalisk.-lokak. \\
\hline Ranskan Guayana & -5 & ei \\
\hline Romania & 0 & maalisk.-lokak. \\
\hline Ruanda & 0 & ei \\
\hline Ruotsi & -1 & maalisk.-lokak. \\
\hline Saksa & -1 & maalisk.-lokak. \\
\hline Sambia & 0 & ei \\
\hline San Marino & -1 & maalisk.-lokak. \\
\hline Saudi-Arabia & +1 & ei \\
\hline
\end{tabular}

\begin{tabular}{|c|c|c|}
\hline$\underline{\text { Valtio }}$ & $\underline{\text { Aikaero }}$ & Mahdollinen kesäaika \\
\hline Senegal & -2 & ei \\
\hline Serbia & -1 & maalisk.-lokak. \\
\hline Sierra Leone & -2 & ei \\
\hline Singapore & +6 & ei \\
\hline Slovakia & -1 & maalisk.-lokak. \\
\hline Slovenia & -1 & maalisk.-lokak. \\
\hline Somalia & +1 & ei \\
\hline Sri Lanka & +3.30 & ei \\
\hline Sudan & +1 & ei \\
\hline Suomi & 0 & maalisk.-lokak. \\
\hline Suriname & -5 & ei \\
\hline Swazimaa & 0 & ei \\
\hline Sveitsi & -1 & maalisk.-lokak. \\
\hline Syyria & 0 & huhtik.-lokak. \\
\hline Tadžikistan & +3 & ei \\
\hline Taiwan & +6 & ei \\
\hline Tansania & +1 & ei \\
\hline Tanska & -1 & maalisk.-lokak. \\
\hline Thaimaa & +5 & ei \\
\hline Togo & -2 & ei \\
\hline Trinidad ja Tobago & -6 & ei \\
\hline Tšad & -1 & ei \\
\hline Tshekki & -1 & maalisk.-lokak. \\
\hline Tunisia & -1 & ei \\
\hline Turkki & 0 & maalisk.-lokak. \\
\hline Turkmenistan & +3 & ei \\
\hline Uganda & +1 & ei \\
\hline Ukraina & 0 & maalisk.-lokak. \\
\hline Unkari & -1 & maalisk.-lokak. \\
\hline Uruguay & -5 & lokak.-maalisk. \\
\hline Uusi-Seelanti & +10 & syysk.-huhtik. \\
\hline Uzbekistan & +3 & ei \\
\hline Valko-Venäjä & +1 & ei \\
\hline Vatikaani & -1 & maalisk.-lokak. \\
\hline Venezuela & -6.30 & ei \\
\hline Venäjä & $+1 /+10$ & ei \\
\hline Kaliningrad & +1 & \\
\hline Viipuri, Pietari, Murmansk & +2 & \\
\hline
\end{tabular}




\begin{tabular}{|lrl|}
\hline Valtio & Aikaero & Mahdollinen kesäaika \\
Moskova & +2 & \\
Izhevsk, Samara & +2 & \\
Perm, Jekaterinburg & +4 & \\
Omsk, Novosibirsk & +5 & \\
Norilsk, Kyzyl & +6 & \\
Bratsk, Ulan-Ude & +7 & \\
Jakutsk & +8 & \\
Habarovsk, Vladivostok & +9 & \\
Magadan & +10 & \\
Petropavlovsk-Kamtshatski & +10 & \\
Vietnam & +5 & ei \\
Viro & 0 & maalisk.-lokak. \\
& & \\
Yhdysvallat & $-7 /-12$ & maalisk.-marrask. \\
New York & -7 & \\
Washington, Miami & -7 & \\
Chicago, Dallas, New Orleans & -8 & \\
Phoenix & -9 & ei \\
Salt Lake City & -9 & \\
Seattle, Los Angeles & -10 & \\
San Fransisco & -10 & \\
Alaska & -11 & \\
Havaiji & -12 & ei \\
Zimbabwe & & \\
& 0 & ei \\
& &
\end{tabular}

(ennen jopa yksitoista) eri aikavyöhykettä. Kiina taas pitää suuresta koostaan huolimatta samaa aikaa koko maansa alueella (ks. s. 64).

\section{Päivämääräraja}

Maapallon jako kahteenkymmeneenneljään aikavyöhykkeeseen merkitsee sitä, että Tyynellemerelle vyöhykkeiden $+12 \mathrm{~h}$ ja $-12 \mathrm{~h}$ välille muodostuu raja, jonka toisella puolella eletään eri vuorokautta kuin toisella.

Jules Vernen kirjassa Maapallon ympäri 80 päivässä kiertää Phileas Fogg maapallon ympäri itäsuuntaan. Hän matkustaa Euroopasta Japaniin, sieltä Amerikkaan ja sitten Atlantin yli takaisin Englantiin. Matka kestää pari tuntia yli 80 vuorokauden, ja Fogg luulee hävinneensä vedon.
Viime hetkessä selviää, että Englannissa eletäänkin vasta edellistä päivää, ja Fogg ehtii ilmoittautumaan Maantieteelliseen seuraan ennen oikeaa määräaikaa.

Vaikka Fogg nukkui matkallaan 80 yötä, oli Englannissa öitä kulunut vasta 79 . Syynä oli se, että Fogg matkusti koko ajan itään päin. Siksi hänen vuorokautensa jäivät parikymmentä minuuttia lyhemmiksi kuin 24 tuntia, ja 80 päivässä eroa ehti tulla kokonaisen vuorokauden verran.

Fogg teki matkansa ennen kuin Washingtonissa sovittiin aikavyöhykkeistä ja päivämäärärajasta. Jos Fogg nykyaikana tekisi vastaavan matkan, muistuttaisi lentoemäntä tai laivan stuertti kohta Japanista lähdön jälkeen, että nyt ylitetään kansainvälinen päivämääräraja. Fogg joutuisi siirtämään muiden kanssamatkustajiensa tavoin päivyrinsä yhtä päivää taaksepäin. Siksi hän tulisi takaisin Lontooseen oikea päivä kalenterissaan, eikä ajassa olisi mitään sekaannusta.

Kansainvälinen päivämääräraja kulkee Tyynellämerellä täsmälleen vastakkaisella puolella maapalloa kuin Greenwichin nollameridiaani. Raja alkaa pohjoisnavalta, kulkee Aasiaa ja Amerikkaa erottavan Beringin salmen läpi, etenee kohti etelää Japanin, Sunda-saarten ja Uuden-Seelannin itäpuolella ja päättyy etelänavalle.

\section{Kellojen uusi tarkkuus}

Kellojen tarkkuus kasvoi pitkin 1900-lukua. Käyttöön saatiin uusia tahdittajia. Sähkökellot keksittiin jo 1800-luvulla, mutta laajemmin niitä alettiin valmistaa vasta vuosisadan vaihteen jälkeen. Sähkökellojen käyttövoima saatiin sähköparistoista, ja tarkka taajuus tuli esimerkiksi ääniraudasta tai kvartsikiteestä.

Kvartsikide värähtelee hyvin tarkasti omalla ominaistaajuudellaan, tavallisesti muutamia kymmeniätuhansia kertoja sekunnissa. Kidekelloilla voitiin aikaa mitata jo pysyvästi sekunnin murto-osien tarkkuudella.

Vielä suurempaan tarkkuuteen päästään atomikelloilla. Ne perustuvat atomien energiatasojen muutoksiin, joissa tiettyä energiahyppäystä vastaa aina täsmälleen samalla taajuudella värähtelevä säteily. Esimerkiksi cesiumatomikellossa atomit värähtelevät hieman yli 9 miljardia kertaa sekunnissa.

Atomikelloja on rakennettu 1900-luvun keskipaikkeilta alkaen, ja ne ovat tämän hetken tarkimpia ajannäyttäjiä. 


\section{Maapallo hidastuu}

1900-luvun alkupuoliskolla ajanmittauksen perusjakso oli yhä vuorokausi. Sekunti märiteltiin päivän avulla: se oli 1/86400 vuorokautta. Mutta kellojen tarkkuus oli nyt noussut niin suureksi, että vuorokausien todelliset pituudet pystyttiin märäämään sekunnin murto-osien tarkkuudella.

Tällaisella tarkkuudella mitattuna ei vuorokausi enää ollutkaan aivan tasainen mitta: vuorokauden pituus hieman vaihteli.

Ilmiö oli itse asiassa huomattu jo 1800-luvulla, kun oli tehty laskelmia antiikin ajan auringonpimennyksistä. Laskuja oli verrattu pimennyksistä säilyneisiin kertomuksiin ja oli huomattu, että pimennykset eivät olleetkaan sattuneet aivan lasketuissa paikoissa. Lasketun ja todellisen paikan ero saattoi olla tuhansia kilometrejä.

Aurinko, kuu ja maa kulkevat radallaan kuin tarkin kello, ja pimennyslaskuissa ei pitänyt olla mitään vikaa. Ainoaksi mahdollisuudeksi keksittiin lopulta, että maapallon pyörimisen oli täytynyt hieman hidastua. Laskuissa oli oletettu, että maapallo oli pyörinyt entisinä aikoina täsmälleen samalla vauhdilla kuin nykyäänkin. Mutta oletetaanpa, että
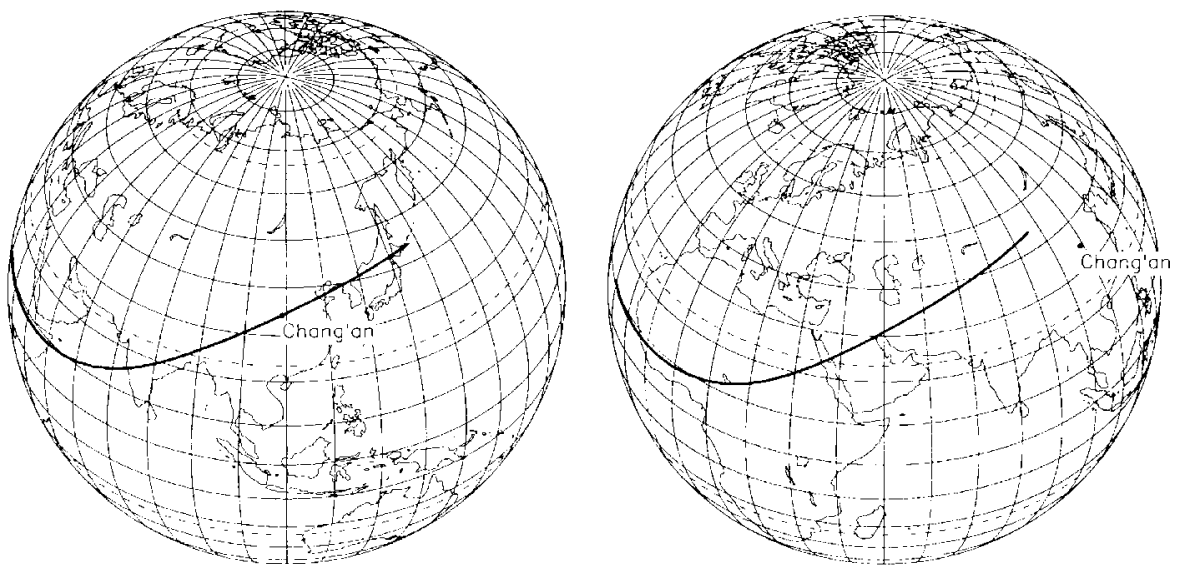

Vuonna $181 \mathrm{eKr}$ sattunut täydellinen auringonpimennys. Jos maapallo olisi entisinä aikoina pyörinyt samalla nopeudella kuin nykyään, pimennys olisi nähty Kiinassa (vasen piirros). Todellisuudessa täydellinen pimennys nähtiin Lähi-idässä (oikea piirros), ja tästä erosta voidaan laskea, kuinka paljon maapallo on hidastunut. (Steve Bellin piirrokset L.V. Morrisonin ja F.R. Stephensonin artikkelista Royal Greenwich Observatoryn Spectrum-lehdestä, lokakuu 1998) maapallo oli menneinä vuosisatoina ja -tuhansina pyörinyt hieman nopeammin. Siksi pimennyskohtaan tullessaan maapallo kääntäisikin hieman eri puolen pimentynyttä aurinkoa kohti, ja siksi pimennys tapahtuisi hieman eri paikassa kuin nykyisellä pyörimisnopeudella laskettuna. Kun pyörimisen oletettiin hidastuneen, saatiin laskut ja havainnot hyvin vastaamaan toisiaan.

Tähtitieteilijät pystyivät laskemaan keskimääräisen eron nykyisen ja entisen vuorokauden pituuden välillä. Jos kahdessatuhannessa vuodessa oli eroa syntynyt kaikkiaan kolmisen tuntia eli noin 10000 sekuntia ja maapallo oli kahdessatuhannessa vuodessa pyörähtänyt akselinsa ympäri 2000 x 365 eli noin 700000 kertaa, oli ero yhtä vuorokautta kohti keskimäärin 1/70 sekuntia. Tämä oli niin pieni ero, että sitä ei 1800-luvulla pystytty yhden vuorokauden eikä edes yhden vuoden aikana huomaamaan.

Mutta 1900-luvulla kellojen tarkkuus oli toinen, ja niinpä voitiin ruveta seuraamaan maapallon pyörimisnopeuden vaihteluita vuodesta toiseen.

Tulokset osoittivat, että hidastuminen ei suinkaan ole tasaista. Välillä nopeus hidastuu keskimääräistä enemmän, välillä - kuten 1800-luvulla oli käynyt - maapallon pyöriminen saattaa pitkän aikaa jopa nopeutua. Mutta sitten se taas palaa hidastuvaan liikkeeseen.

Maapallon vähittäisen hidastumisen syy on selvä: sen aiheuttaa vuorovesien kitka. Vuorovesiaallot nousevat ja laskevat maapallon merillä ja kuljettavat rannikoilla mahtavia vesimassoja edestakaisin. Vesimassojen liikkeet aiheuttavat kitkaa, joka vähitellen jarruttaa maapallon pyörimistä. Maapallon jarrumiehenä on siten kuu, joka vuorovedet aiheuttaa.

Liikkeen jarruuntuminen on hyvin vähäistä, ja pyörimisessä havaitaan paljon suurempia lyhytaikaisia muutoksia. Niiden syyt eivät ole yhtä hyvin tiedossa. Yhtenä tekijänä ovat tuulet, jotka puhaltavat pinnan suuntaisesti ja vaikuttavat maapallon pyörimiseen. Toisena tekijänä ovat maanjäristykset, joissa kalliot nopeasti liikahtavat toistensa suhteen. Kolmantena tekijänä on kivimassojen hidas virtailu maapallon sisällä. Pinnalla virtailu näkyy esimerkiksi mannerliikuntana. Ja neljäs tekijä ovat "tuntemattomat syyt" eli tutkijat eivät tiedä, mitkä muut mahdolliset ilmiöt maapallon pinnalla tai sisällä voivat vaikuttaa sen pyörimiseen.

Vuorovesien kitka hidastaa maapallon pyörimistä sellaisella vauhdilla, että vuorokauden pituus muuttuu vuosisadassa 0,0016 sekunnilla. Muut 


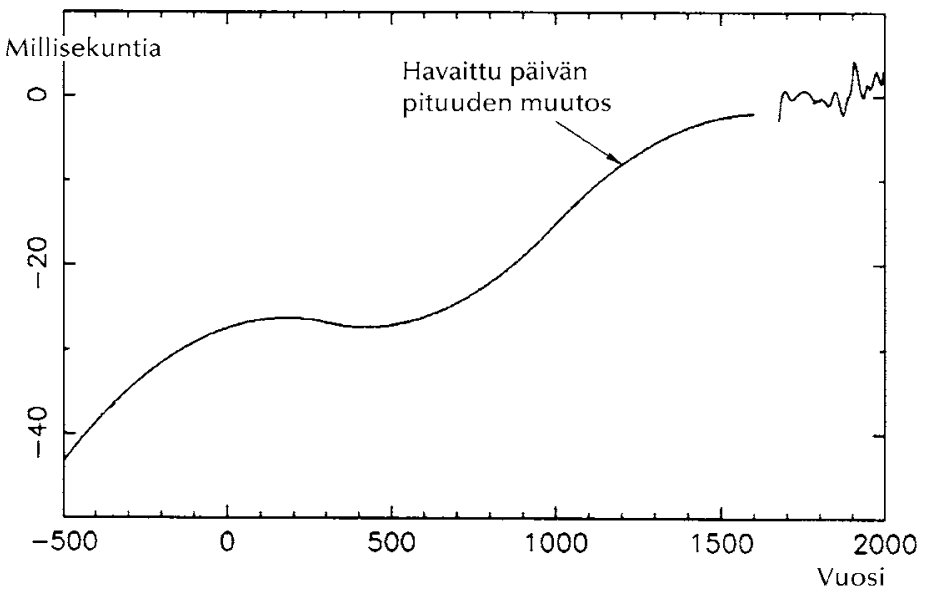

Päivän pituuden muuttuminen 2500 viime vuoden aikana. Vaaka-akselilla on vuosiluku ja pystyakselilla ero päivän pituudessa nykyhetken ja menneen vuoden välillä. Esimerkiksi vuoden 0 paikkeilla vuorokausi oli noin 27 sekunnin tuhannesosaa lyhempi kuin nykyään. (Piirros L.V. Morrison ja F.R. Stephenson)

syyt aiheuttavat pyörimiseen paljon suurempaa epätasaisuutta. Esimerkiksi vuonna 1954 vuorokausi oli yhden tuhannesosasekunnin pitempi kuin 24 tuntia, mutta vuonna 1970 jo kolmisen tuhannesosaa pitempi. Yhdessä vuodessa tulee tästä jo sekunnin luokkaa olevia eroja.

\section{Päivästä vuoteen, vuodesta sekuntiin}

Yhtä kaikki 1900-luvun puoliväliin mennessä oli selvinnyt, ettei maapallo olekaan niin tarkka kello kuin oli toivottu. Atomikellot kävivät jo paljon tarkemmin. Tutkijoilla piti kuitenkin olla jokin luonnon jakso, johon atomikellojakin voitaisiin verrata. Mutta mistä löytyisi maapallon pyörimistä tarkempi luonnon kello?

Apu löytyi taas tähtitaivaalta. Vaikka maapallo pyöriikin akselinsa ympäri epätasaisesti, se toki kiertää aurinkoa erittäin tarkasti Newtonin painovoimalain mukaan.

Vuonna 1960 luovuttiin päivästä ajanmittauksen perustana. Uudeksi perustaksi otettiin vuosi eli maapallon kiertoaika auringon ympäri. Sekuntia ei enää määritelty 1/86400 vuorokautena, vaan sekunti oli $1 / 31$ 556925,9747 vuotta.

Uusi määrittelytapa ei muuttanut sekunnin pituutta, vaan antoi sen entistä vakaammin. Päivän pituus saisi vaihdella miten halusi, lyhentyä tai pidentyä, ja sekunti pysyy siitä huolimatta yhtä tarkkana.

Vuoden pituus saadaan määrätyksi mittaamalla auringon, kuun, planeettojen ja tähtien paikkoja. Vuoden pituuden avulla määritelty aika on niin täsmällistä, että siihen kertyy sekunnin virhe vasta kolmessakymmenessä vuodessa.

Atomikellot kehittyivät pitkin 1960-lukua yhä tarkemmiksi, ja aikaa seurattiin käytännössä niiden avulla eikä taivasta tähyilemällä. Vuoden pituuden tarkka arvo oli hankala määrittää tähdistä, kun taas atomikello antoi tarkan ajan välittömästi.

Niinpä sekunnin märitelmää muutettiin toisen kerran lyhyen ajan kuluessa. Nyt tähtitiede, joka oli antanut maapallon asukkaille oikean ajan tuhansia vuosia, sai väistyä uudemman tieteen, atomifysiikan, tieltä. Vuonna 1967 pidetyssä kansainvälisessä kokouksessa hyväksyttiin sekunnin uusi määritelmä, joka perustuu cesiumatomin värähtelyyn: "Sekunti on 9192631770 perustilassa olevan cesium 133 -isotoopin säteilemän valon jakson aikaa säteilyssä, joka syntyy hyperhienotasojen $\mathrm{F}=4$ ja $\mathrm{F}=3$ välisessä siirtymässä."

Tavalliselle pulliaiselle määritelmä ei varmasti sano paljoakaan, mutta fyysikot pystyvät sen avulla mittaamaan aikaa ennennäkemättömän tarkasti, paljon tarkemmin kuin tähtitieteen avulla. Cesiumatomikello saa käydä 30000 vuotta, ennen kuin sen käyntiin tulee edes sekunnin virhettä.

Käytännössä aikaa mitataan ympäri maailmaa usealla atomikellolla, joiden keskimääräinen lukema määrittelee niinsanotun kansainvälisen atomiajan. Siitä käytetään lyhennettä IAT (International Atomic Time), ja se etenee vielä täsmällisemmin kuin minkään yksittäisen atomikellon käynti. IAT-aikaan kertyy sekunnin virhe vasta kolmessa miljoonassa vuodessa.

\section{GMT:stä yleisaikaan}

Maapallon kellot seurasivat Greenwichin keskiaurinkoaikaa (tai siitä tasatunneilla poikkeavia lukemia) 1960-luvulle asti, jolloin aikamittaus annettiin atomikellojen tehtäväksi. Maapallolla ei kuitenkaan voitu ruveta elämään atomikellojen aikaa, koska silloin olisi vähitellen jouduttu epätahtiin maapallon pyörimisen kanssa. Kun atomikellot käyvät tasai- 
sesti mutta maapallon tahti hidastuu, alkaa atomiajan ja luonnon ajan välille kertyä eroa. Tarkalla atomikellolla mitattuna alkaisi keskipäivän hetki hiljalleen liukua pois oikealta paikaltaan.

Maapallon kellot ja radioitten aikamerkit haluttiin kuitenkin pitää maan pyörimisen suhteen oikeassa. Avuksi kehitettiin kokonaan uusi siviiliaika, koordinoitu yleisaika eli UTC. (UTC-lyhenne otettiin käyttöön Ranskan ja Englannin kädenväännön jälkeen. Ranskalaiset ehdottivat lyhennettä TUC eli Temps Universel Cordonné ja englantilaiset CUT eli Coordinated Universal Time. Kompromissina hyväksyttiin UTC.) Sen käynti on yhtä tasaista kuin atomiajan, mutta siihen tehdään aika ajoin pieniä korjauksia, jotta se pysyy maapallon tahdissa.

UTC oli ensin 1960-luvun alussa vain tutkimuslaitosten käytössä Yhdysvalloissa, Englannissa ja parissa muussa maassa. Suurin osa valtioista piti edelleen voimassa vanhat Greenwichin aikaan perustuvat keskiaurinkoaikansa.

UTC-aikaan tehtiin aluksi korjauksia useita kertoja vuodessa. Esimerkiksi 1964 aikamerkkejä tarkistettiin huhtikuun alussa ja syyskuun alussa 0,1 sekuntia kumpanakin ja vielä lokakuussa 0,01 sekuntia, sen mukaan kuin maapallo oli hidastunut.

Jatkuva kellojen siirtely oli kuitenkin hankalaa, ja siksi 1970-luvun alussa muutettiin UTC-ajan märitelmää siten, että korjaus tehtiin vasta sitten, kun ero atomiaikaan alkoi kasvaa lähelle seuraavaa täyttä sekuntia. Näin päästiin vihdoin sellaiseen aikajärjestelmään, joka voitiin hyväksyä laajaan kansainväliseen käyttöön. Uusi UTC-aika otettiin käyttöön vuoden 1972 alussa, jolloin Suomikin hylkäsi keskiaurinkoajan ja alkoi elää koordinoitua yleisaikaa.

\section{Karkaussekunnit}

Uuden UTC-ajan olennaisena piirteenä ovat karkaussekunnit, joiden avulla maapallon pyörimisnopeuden vaihtelut otetaan huomioon. Kun ero atomiaikaan alkaa lähestyä seuraavaa täyttä sekuntia, ilmoittaa Pariisissa toimiva aikakeskus, milloin aikaan lisätään yksi sekunti. Lisäys tehdään vuoden alussa tai puolivälissä.

Esimerkiksi tammikuussa 2012 saatiin Pariisista seuraava tiedote:

UTC:n aikamuutos heinäkuun 1. päivänä 2012. Positiivinen karkaus- sekunti lisätään aikaan kesäkuun 2012 lopussa. UTC-ajan peräkkäiset sekunnit kuukaudenvaihteessa ovat seuraavat:

2012 kesäkuun 30. 23 h 59 min 59 s

2012 kesäkuun 30. 23 h 59 min $60 \mathrm{~s}$

2012 heinäkuun 1. O h 0 min 0 s.

Erotus koordinoidun yleisajan UTC ja kansainvälisen atomiajan IAT välillä on

vuoden 2009 tammikuun 1. päivästä, klo O UTC, vuoden 2012 heinäkuun 1. päivään, klo 0 UTC: UTC - IAT = -34 s vuoden 2012 heinäkuun 1. päivästä, klo O UTC, eteenpäin kunnes toisin ilmoitetaan: $U T C-I A T=-35$ s.

Karkaussekunteja voidaan liittää UTC-aikaan joulukuun tai kesäkuun lopussa, riippuen maapallon pyörimisen muutoksesta. Tämä tiedote lähetetään kuuden kuukauden välein joko ilmoittamaan, että UTC-aikaa muutetaan, tai kertomaan että muutosta ei tehdä seuraavana mahdollisena päivämääränä.

Uusin karkaussekuntitiedote löytyy myös internetistä osoitteesta http://hpiers.obspm.fr/iers/bul/bulc/bulletinc.dat.

Maapallon pyöriminen muuttui 1970-luvulla niin, että karkaussekunti lisättiin joka vuosi. Seuraavina vuosikymmeninä karkaussekunteja lisättiin 1-2 vuoden välein. Vuoden 1999 jälkeen maapallon tahti jostakin syystä, luultavasti valtamerien lämpenemisen takia, hieman muuttui, ja seuraava karkaussekunti lisättiin vasta vuoden 2006 alussa. Uusimmat lisäykset on tehty 2009 ja 2012. Seuraavan karkaussekunnin lisäystä ei pystytä vielä ennakoimaan.

Suomen virallinen aika on vuodesta 1981 alkaen saatu Valtion teknillisen tutkimuskeskuksen sähkötekniikan laboratoriosta Espoosta. Siellä oleva atomikello on lukittu kansainväliseen radiomerkkiin, joka siirtää kansainvälisen ajan ympäri maapalloa. Espoon aikakeskuksesta välitettiin viidentoista vuoden ajan tarkka aika $\mathrm{mm}$. Yleisradion aikamerkkeihin.

Espoon aikakeskus on nykyään VTT:n automaatio- ja mittaustekniikan metrologian ryhmän kansallinen mittanormaalilaboratorio. Se pitää 


\section{Karkaussekunnit}

arkaussekunteja on lisätty aikaamme vuodesta 1972 alkaen, jolloin koordinoitu yleisaika UTC otettiin käyttöön. Karkaussekunti on lisätty allaolevina päivinä. Lisäys tehdään aina edellisenä yönä vuorokauden vaihtuessa (UT-ajan mukaisesti eli talvella kello 2 ja kesällä klo 3 Suomen aikaa) siten että vuorokauden vaihteen peräkkäiset sekunnnit ovat 23.59.58, 23.59.59, 23.59.60, 0.00.00, 0.00.01 jne.

$\begin{array}{ll}1972 \text { heinäk. } 1 . & 1981 \text { heinäk. } 1 . \\ 1973 \text { tammik. } 1 . & 1982 \text { heinäk. } 1 . \\ 1974 \text { tammik. } 1 . & 1983 \text { heinäk. } 1 . \\ 1975 \text { tammik. } 1 . & 1985 \text { heinäk. } 1 . \\ 1976 \text { tammik. } 1 . & 1988 \text { tammik. } 1 . \\ 1977 \text { tammik. } 1 . & 1990 \text { tammik. } 1 . \\ 1978 \text { tammik. } 1 . & 1991 \text { tammik. } 1 . \\ 1979 \text { tammik. } 1 . & 1992 \text { heinäk. } 1 . \\ 1980 \text { tammik. } 1 . & 1993 \text { heinäk. } 1 .\end{array}$

1994 heinäk. 1. 1996 tammik. 1. 1997 heinäk. 1. 1999 tammik. 1. 2006 tammik. 1. 2009 tammik. 1. 2012 heinäk. 1.

1993 heinäk. 1. toinen tekijä, jonka takia herätyskellojakin on rukattava kahdesti vuodessa: kesäaika ja siihen liittyvät tunnin siirrot keväällä ja syksyllä.

\section{Kesäaika on vanha keksintö}

Kesäaika tarkoittaa sitä, että keväällä kellojen osoittimia siirretään tunnilla eteenpäin ja syksyllä taas tunnilla taaksepäin. Syynä siirtoon on se, että ihmisten valvomisrytmi on keinovalon myötä joutunut eri tahtiin kuin auringon kulku. Aamuisin nukutaan kesällä pitkään auringon jo noustua, ja iltaisin valvotaan sitten lamppujen valossa.

Tunnin siirrolla saadaan ihmisten valveillaoloaika sovitetuksi keskemmälle vuorokauden valoisaa aikaa. Näin säästetään mm. energiaa kun ei tarvita niin paljon keinovaloa, ihmiset ovat terveempiä kun he saavat enemmän aurinkoa, liikenneonnettomuudet vähenevät kun ei tarvitse ajaa niin paljon pimeässä jne.

Jo kaksisataa vuotta sitten Benjamin Franklin ehdotti Yhdysvalloissa, että kynttilöiden säästämiseksi siirrettäisiin kesäisin kelloa tunnilla tai parilla eteenpäin. Näin saataisiin valvomisaika paremmin vastaamaan auringon kulkua.

Varsinaisena kesäajan isänä pidetään kuitenkin englantilaista William Willetiä. Hän kirjoitti aiheesta 1907 kirjan "Päivänvalon tuhlaus" ja yritti useaan otteeseen saada parlamentissa läpi ehdotusta kesäaikaan siirtymiseksi.

Vasta ensimmäisen maailmansodan tuoma polttoainepula sai päättäjät taipumaan Willetin ehdotuksiin. Englanti siirtyi kesäaikaan 1916 - vuosi Willetin kuoleman jälkeen.

Jo edellisenä vuonna, 1915, oli kuitenkin kesäaika ollut käytössä Saksassa, jolla oli siten kunnia olla kesäaikakysymyksessä edelläkävijänä koko maailmassa.

Maailmansodan jälkeen polttoainetilanne taas keventyi ennen kuin toinen maailmansota aiheutti uuden kriisin. Esimerkiksi Yhdysvalloissa oli pysyvä kesäaika helmikuusta 1942 syyskuuhun 1945, jolloin kaikki kellot kävivät tunnin normaalia edellä.

Suomessakin kesäaikaa kokeiltiin 1942, mutta kokemuksia ei pidetty erityisen myönteisinä eikä käytäntöä jatkettu.

Toisen maailmansodan jälkeen kesäaikaa käytettiin aikaisempaa hieman laajemmin. Monissa maissa sitä pidettiin kuitenkin edelleen tar-
Karkaussekuntien ohella on aikaan ilmestynyt viime vuosikymmeninä 


\section{Kesåaikaan siimrtatin tangăn lorstaina}

\section{4. kello 24.}

Valtioneuvosto on maaliakuun 20 jhiving 194: antamallatan wetukellia

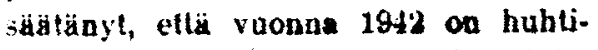
kuun 2 paivăg ja lokakuun 4 päivăn välisenä aikana laillisena keskiaurinkoujkana noudalettava keshaikua, johon siirrytain aited, otta kellot huhtikaun 2 pilivana kello 24 siirretaln tunti eteenpàin, ja josta trovutaan dirthmalla kellot lokakuun 4 pliving klo 1 lunti tarksepäin.

Annelun acelukson mukaan slirre. täun siis kellot tanti etesppăin toro tain ja perjantain vălimenà yonł klo 24.

peettomana, ennen kuin uudet energiakriisit iskivät 1970-luvulla.

Vuonna 1980 liittyivät kesäajan käyttäjiin mm. kaikki pohjoismaat Suomea lukuun ottamatta, ja seuraavana vuonna vielä Neuvostoliitto. Suomen liikenneyhteydet ja muu yhteydenpito muualle Eurooppaan olisi käynyt hankalaksi, jos aikaero muihin maihin olisi kesällä ollut erilainen kuin talvella, ja siksi Suomi lähes viimeisenä maana Euroopassa siirtyi kesäaikaan 1981.

Maamme sijainti on niin pohjoinen, että keskikesällä aurinko paistaa täällä niin aamulla kuin illallakin hyvin pitkään. Tunnin siirto ei merkitse valoisuudessa mitään säästöä. Sen sijaan keväällä ja syksyllä meilläkin kesäajan käyttöönotolla saadaan yksi pimeä iltatunti korvatuksi valoisalla aamutunnilla, ja siksi kesäajan hyöty ei rajoitu pelkästään kansainvälisen liikenteen parempaan sujumiseen.

Miinuspuolelle voidaan ehkä laskea se, että kellon ja luonnon rytmit poikkeavat toisistaan yhä enemmän. Ennen kesäaikapäätöksen tekoa valtioneuvoston kanslia teki Suomessa lausuntokierroksen, jossa oli mu-

\section{Kesäajan käyttö Suomessa 1942-2013}

vuosi kesäaika alkoi kesäaika päättyi

$1942 \quad$ 2.4. klo $24 \rightarrow 1 \quad$ 4.10. klo $1 \rightarrow 0$

1981 29.3. klo $2 \rightarrow 3 \quad$ 27.9. klo $3 \rightarrow 2$

$1982 \quad$ 28.3. klo $2 \rightarrow 3 \quad$ 26.9. klo $3 \rightarrow 2$

1983 27.3. klo $3 \rightarrow 4 \quad$ 25.9. klo $4 \rightarrow 3$

$1984 \quad$ 25.3. klo $3 \rightarrow 4 \quad$ 30.9. klo $4 \rightarrow 3$

1985 31.3. klo $3 \rightarrow 4 \quad$ 29.9. klo $4 \rightarrow 3$

1986 30.3. klo $3 \rightarrow 4 \quad$ 28.9. klo $4 \rightarrow 3$

1987 29.3. klo $3 \rightarrow 4 \quad$ 27.9. klo $4 \rightarrow 3$

1988 27.3. klo $3 \rightarrow 4 \quad$ 25.9. klo $4 \rightarrow 3$

1989 26.3. klo $3 \rightarrow 4 \quad$ 24.9. klo $4 \rightarrow 3$

$1990 \quad$ 25.3. klo $3 \rightarrow 4 \quad$ 30.9. klo $4 \rightarrow 3$

1991 31.3. klo $3 \rightarrow 4 \quad$ 29.9. klo $4 \rightarrow 3$

1992 29.3. klo $3 \rightarrow 4 \quad$ 27.9. klo $4 \rightarrow 3$

$1993 \quad$ 28.3. klo $3 \rightarrow 4 \quad$ 26.9. klo $4 \rightarrow 3$

1994 27.3. klo $3 \rightarrow 4 \quad$ 25.9. klo $4 \rightarrow 3$

1995 26.3. klo $3 \rightarrow 4 \quad$ 24.9. klo $4 \rightarrow 3$

1996 31.3. klo $3 \rightarrow 4 \quad$ 27.10. klo $4 \rightarrow 3$

$1997 \quad$ 30.3. klo $3 \rightarrow 4 \quad$ 26.10. klo $4 \rightarrow 3$

1998 29.3. klo $3 \rightarrow 4 \quad$ 25.10. klo $4 \rightarrow 3$

1999 28.3. klo $3 \rightarrow 4 \quad$ 31.10. klo $4 \rightarrow 3$

2000 26.3. klo $3 \rightarrow 4 \quad$ 29.10. klo $4 \rightarrow 3$

$2001 \quad$ 25.3. klo $3 \rightarrow 4 \quad$ 28.10. klo $4 \rightarrow 3$

2002 31.3. klo $3 \rightarrow 4 \quad$ 27.10. klo $4 \rightarrow 3$

2003 30.3. klo $3 \rightarrow 4 \quad$ 26.10. klo $4 \rightarrow 3$

2004 28.3. klo $3 \rightarrow 4 \quad$ 31.10. klo $4 \rightarrow 3$

2005 27.3. klo $3 \rightarrow 4$ 30.10. klo $4 \rightarrow 3$

2006 26.3. klo $3 \rightarrow 4 \quad$ 29.10. klo $4 \rightarrow 3$

2007 25.3. klo $3 \rightarrow 4 \quad$ 28.10. klo $4 \rightarrow 3$

$2008 \quad$ 30.3. klo $3 \rightarrow 4 \quad$ 26.10. klo $4 \rightarrow 3$

2009 29.3. klo $3 \rightarrow 4 \quad$ 25.10. klo $4 \rightarrow 3$

$2010 \quad$ 28.3. klo $3 \rightarrow 4 \quad$ 31.10. klo $4 \rightarrow 3$

2011 27.3. klo $3 \rightarrow 4 \quad$ 30.10. klo $4 \rightarrow 3$

$2012 \quad$ 25.3. klo $3 \rightarrow 4 \quad$ 28.10. klo $4 \rightarrow 3$

2013 31.3. klo $3 \rightarrow 4 \quad$ 27.10. klo $4 \rightarrow 3$ 
kana myös almanakkatietojen virallinen laskija, Helsingin yliopiston tähtitieteen laitos. Kesäajan käyttöönottohan muuttaa kaikkia almanakassa ilmoitettuja kellonaikoja. Jokaista auringon ja kuun nousua ja laskua on siirrettävä tunnilla eteenpäin.

Myös puolenpäivän hetki siirtyy yhä kauemmas kello 12:sta. Päivä on puolessa silloin, kun aurinko on korkeimmillaan ja suoraan etelässä. Suomen normaaliaikaan eli talvikaudella auringon etelässäolo sattuu vähän kello 12:n jälkeen, mutta kesäajan vallitessa vasta kello 13:n ja 13.30:n välillä.

Läntisimmässä Suomessa, jossa auringon näyttämä aika on vielä parikymmentä minuuttia kauempana virallisesta ajasta, voi keskipäivän hetki olla lähellä kello 14:ä. Niinpä Helsingin yliopisto arvelikin lausunnossaan, että "näin suuri poikkeama todellisen aurinkoajan ja virallisen ajan välillä hämärtää ihmisten käsityksiä kellonaikojen ja vuorokauden aikojen välisestä luonnollisesta yhteydestä".

Vuoden 1981 kesäajasta saatiin kuitenkin myönteisiä kokemuksia, ja kesäaika säädettiin myös seuraaville vuosille. Siirtymäpäiviksi valittiin samat kuin muuallakin Länsi-Euroopassa, maaliskuun lopun ja syyskuun lopun viikonvaihteet. Maaliskuun lopulla sunnuntaiaamuna klo 3 (alkuvuosina klo 2) siirrettiin kelloa tunnilla eteenpäin, klo 4:ään, ja syyskuun lopulla takaisin klo 4:stä 3:een (alkuvuosina 3:sta 2:een). Sunnuntain aamuyö oli valittu siksi, että liikenne on vähäisintä ja siirtyminen tuottaa vähiten haittaa.

\section{Vuoden pisin kuukausi}

ykyään kun kesäajan päättyminen tapahtuu lokakuussa, olemme saaneet uuden vastauksen kysymykseen, mikä on vuoden pisin kuukausi. Oikea vastaus on lokakuu. Aikaisemmin tähän kysymykseen oli seitsemän oikeata vastausta, sillä tammi-, maalis-, touko-, heinä-, elo-, loka- ja joulukuussa on kaikissa 31 päivää.

Vuodesta 1996 alkaen kesäajan loppuminen on ollut lokakuussa entisen syyskuun sijaan, ja siten lokakuu on pidentynyt tunnilla. Lokakuun viimeisenä sunnuntaiaamuna elämme kahteen kertaan tunnin klo 3:sta klo 4:ään. Lokakuun pituus on siten 745 tuntia, kun tammi-, touko-, heinä-, elo- ja joulukuun pituus on 744 tuntia ja maaliskuun 743 tuntia.
Vuodesta 1995 alkaen, kun Suomi on ollut EU:n jäsenenä, asia on ollut jo korkeammassa kädessä. Kesäajasta päätetään EU-maiden yhteisellä päätöksellä, ja Suomen tehtävänä on vain toteuttaa EU-direktiivi meidän maamme kohdalla. Kun päättäjiä oli useampia, tuli yhteisen ajan sopiminen vaikeammaksi. Englanti oli noudattanut kesäaikaa maaliskuusta lokakuuhun eikä suostunut muuttamaan omaa käytäntöään. Niinpä muut EU-maat taipuivat Englannin tahtoon, ja vuodesta 1996 alkaen kesäaika on meilläkin ulottunut lokakuun viimeiseen sunnuntaihin.

1990-luvun lopulla kesäaikapäätöksiä tehtiin kolmeksi vuodeksi kerrallaan, mutta vuodesta 2002 alkaen päästiin vihdoin kestävämpään ratkaisuun. EU:n liikenneministerit katsoivat, että kesäajasta on tullut EU:n alueella pysyvä käytäntö eikä sitä tarvitse enää päättää vain pariksi vuodeksi kerrallaan. Niinpä kesäaika on nykyään kaikissa EU-maissa voimassa maaliskuun viimeisen sunnuntaiaamun ja lokakuun viimeisen sunnuntaiaamun välisenä aikana, ja päätös on voimassa kunnes toisin sovitaan

\section{Aika on suhteellista}

Olemme tähän asti käsitelleet aikaa, ikään kuin se etenisi aina ja kaikkialla täsmälleen samalla nopeudella.

Suunnilleen näin onkin asian laita, jos puhutaan maanpinnalla olevista kelloista. Mutta esimerkiksi avaruuslentäjät matkustelevat maapallon kiertoradalla ja kuussa, ja avaruusluotaimet ovat lennelleet ympäri aurinkokuntaa.

Koska tähtitieteessä joudutaan käsittelemään erilaisissa liiketiloissa ja erilaisissa painovoimakentissä olevia laitteita, on siellä otettava huomioon ajan suhteellisuus. Ajan suhteellisuus tarkoittaa sitä, että aika voi edetä eri paikoissa eri tahtiin.

Ajan suhteellisuuden keksi Albert Einstein 1900-luvun alussa, mutta tuolloin ei ollut mitään keinoa testata ilmiön todellisuutta. Maapallolla tai sen lähellä aika kuluu suhteellisuusteoriankin mukaan kaikkialla samassa tahdissa miljoonasosasekunnin tarkkuudella.

Asia sai merkitystä vasta 1950-luvun jälkeen, kun atomikellojen käyntitarkkuudessa päästiin parempaan kuin miljoonasosasekuntiin. Kuuluisassa kokeessa vuonna 1971 lennätettiin atomikello suihkukoneilla kaksi kertaa maapallon ympäri ja verrattiin matkan jälkeen sen näyttä- 


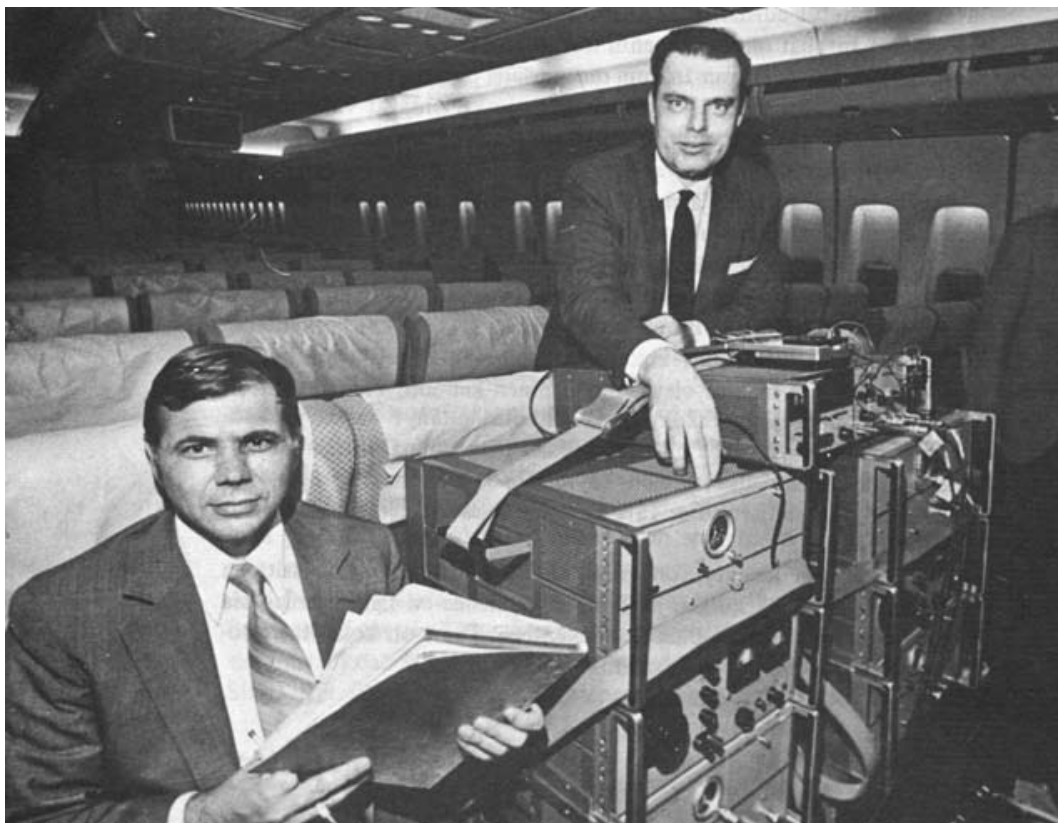

Atomikellot lähdössä lennolleen maapallon ympäri lokakuussa 1971. (Kuva U.S. Naval Observatory)

mää aikaa maanpinnalla pysyneiden kellojen aikaan. Koska lentomatkan tehnyt kello oli ollut liikkeessä ja pienemmässä painovoimakentässä (kymmenen kilometriä maanpinnan yläpuolella), sen piti näyttää lennon jälkeen eri aikaa.

Ja juuri näin kävi: lentomatkalla oli kulunut noin 0,2 miljoonasosasekuntia enemmän aikaa kuin maanpinnalla.

Kosmonauteilla ja astronauteilla, jotka lentävät viikkoja tai kuukausia avaruudessa, ero on jo tuntuvampi. Esimerkiksi kuussa käyneet Apolloastronautit vanhenivat lennoillaan lähes millisekunnin enemmän kuin maan päälle jääneet toverinsa, koska he olivat koko ajan heikommissa painovoimakentissä.

Tähtitieteilijät ovat joutuneet laskuissaan ottamaan käyttöön aivan oman ajan, joka ottaa suhteellisuusteorian ilmiöt huomioon. Sitä sanotaan nykyään maapallonajaksi (englanniksi Terrestrial Time). Vain sen avulla voidaan planeettojen ja luotainten liikkeet laskea tarkasti, mutta ilman sitä laskut eivät täsmää todellisuuden kanssa.

\section{Mustien aukkojen ympärillä}

Einsteinin suhteellisuuteoria kertoo, että aika hidastuu kahdessa eri tapauksessa. Ensimmäinen on kiihtyvässä liikkeessä olevassa raketissa ja toinen suurissa painovoimakentissä.

Orson Scott Cardin kirjassa Kuolleiden puolustaja matkustaa päähenkilö, Ender, raketilla planeetalta toiselle. Raketin vauhti kiihtyy välillä lähelle valon nopeutta ja sitten taas hidastuu, kun tullaan seuraavalle planeetalle. Matkaajien mielestä matka on kestänyt muutamia kuukausia, mutta planeetoilla aikaa on kulunut kymmeniä vuosia. Ender pysyy nuorena, vaikka hänen veljensä kuolee maan päällä vanhuuteen. Kukaan ei lopulta usko, että tämä nuori mies on sama Ender, joka useita sukupolvia aikaisemmin pelasti maapallon vierailta hyökkääjiltä.

Vielä suurempia eroja ajan kulumisessa tapahtuu äärimmäisen suurissa painovoimakentissä. Sellaisia tavataan tähtitaivaalta luhistuneiden tähtien lähellä. Näitä kappaleita sanotaan mustiksi aukoiksi. Luhistuneen tähden läpimitta on vain parikymmentä kilometriä, mutta siinä on ainetta saman verran kuin raskaassa tähdessä.

Mustan aukon painovoimakenttä on murskaavan suuri, ja mustan aukon lähellä ajan suhteellisuus venyy äärimmilleen. Aukon lähellä olevan kellon viisari saattaa liikahtaa vain sekunnin eteenpäin, kun muualla avaruudessa aikaa kuluu tuhat vuotta.

Ehkä joskus kaukaisessa tulevaisuudessa avaruusmatkatoimistot tarjoavat "nuorennusmatkoja", joilta ihmiset palaavat paljon maanpäälisiä ikätovereitaan nuorempina. Tai mustien aukkojen lähelle järjestetään "ikuisen nuoruuden farmeja", joiden asukkaat säilyvät nuorekkaina vaikka maapallolla kuolee sukupolvi toisensa jälkeen.

Ajan suhteellisuus on nykyään todettu jo niin monessa kokeessa oikeaksi, että koko aikakäsitys on täytynyt ajatella uudella tavalla. Aika ei ole enää vääjäämättömän tasaista, vaan ajan etenemisnopeus voi joissakin paikoissa hidastua normaalista käynnistä hiipimiseksi tai etanan mateluksi. 


\section{LUONNON \\ MERKKIPÄIVIÄ VUODEN VARRELLA}

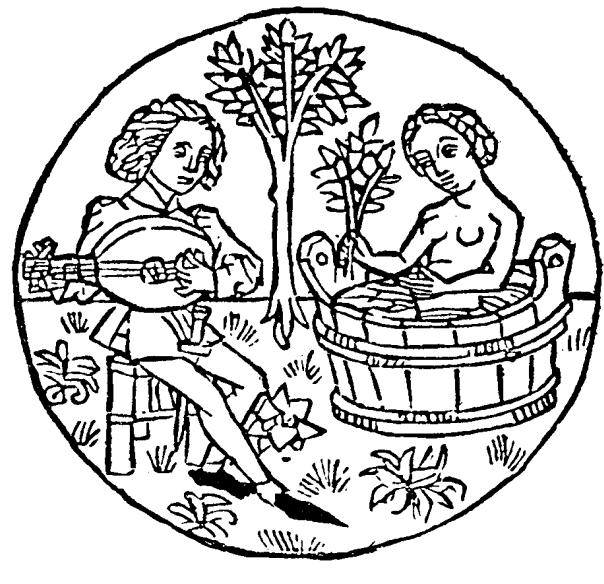

Toukokuun piirros Johannes von Gmundenin kalenterissa: Rakastamisen aika. 
aikoihin, säätieteilijät puhuvat "termisistä vuodenajoista" eli lämpötilan mukaan määräytyvistä vuodenajoista ja tähtitieteilijät määrittelevät vuodenajat tasaus- ja seisauspisteiden avulla ja voivat sanoa minuutilleen, milloin yksi tähtitieteellinen vuodenaika loppuu ja toinen alkaa.

\section{Vuodenaikojen määritelmät}

Tavallisessa puheessa sanotaan, että talvi käsittää suunnilleen joulu-, tammi- ja helmikuun, kevät maalis-, huhti- ja toukokuun, kesä kesä-, heinä- ja elokuun ja syksy syys-, loka- ja marraskuun.

\section{Helsinki}

\begin{tabular}{|c|c|c|c|c|c|c|c|c|c|c|c|c|}
\hline Päivä & 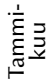 & 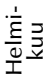 & 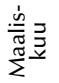 & 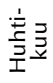 & 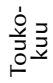 & 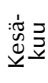 & : & 悉吾 & 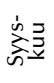 & 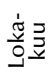 & 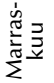 & $\frac{1}{\partial} \bar{z}$ \\
\hline 1 & $-2,9$ & $-5,0$ & $-3,5$ & 1,1 & 7,2 & 12,8 & 16,6 & 18,0 & 14,0 & 8,9 & 4,1 & $-0,8$ \\
\hline 2 & $-2,9$ & $-5,0$ & $-3,4$ & 1,3 & 7,5 & 12,9 & 16,8 & 17,9 & 13,8 & 8,8 & 3,9 & $-0,9$ \\
\hline 3 & $-3,0$ & $-5,1$ & $-3,2$ & 1,5 & 7,7 & 13,0 & 16,9 & 17,9 & 13,6 & 8,6 & 3,7 & $-1,0$ \\
\hline 4 & $-3,0$ & $-5,1$ & $-3,1$ & 1,6 & 7,9 & 13,1 & 17,0 & 17,8 & 13,4 & 8,5 & 3,6 & $-1,1$ \\
\hline 5 & $\begin{array}{l}-3,1 \\
\end{array}$ & $-5,1$ & $-2,9$ & 1,8 & 8,1 & 13,3 & 17,1 & 17,7 & 13,3 & 8,3 & 3,4 & $-1,3$ \\
\hline 6 & $\begin{array}{l}-3,2 \\
\end{array}$ & $-5,1$ & $\begin{array}{l}-2,8 \\
\end{array}$ & $\begin{array}{l}2,0 \\
2,0\end{array}$ & 8,4 & 13,4 & 17,2 & 17,6 & 13,1 & 8,1 & $\begin{array}{l}3,7 \\
3,2\end{array}$ & $\begin{array}{l}-1,4 \\
-1,4\end{array}$ \\
\hline 7 & $\begin{array}{l}-3,2 \\
-3,2\end{array}$ & $-5,1$ & $\begin{array}{l}-2,6 \\
\end{array}$ & 2,2 & 8,6 & 13,5 & 17,3 & 17,5 & 12,9 & 8,0 & 3,0 & $-1,4$ \\
\hline 8 & $-3,3$ & $-5,1$ & $-2,5$ & 2,3 & 8,8 & 13,6 & 17,4 & 17,4 & 12,8 & 7,8 & 2,9 & $-1,5$ \\
\hline 9 & $-3,4$ & $-5,1$ & $-2,4$ & 2,5 & 9,0 & 13,8 & 17,5 & 17,3 & 12,6 & 7,7 & 2,7 & $-1,6$ \\
\hline 10 & $\begin{array}{l}-3,4 \\
-3,4\end{array}$ & $-5,1$ & $\begin{array}{l}-2,7 \\
-2,2\end{array}$ & 2,7 & $\begin{array}{l}9,0 \\
9,2\end{array}$ & 13,9 & 17,6 & 17,2 & 12,4 & 7,5 & 2,5 & $\begin{array}{l}1,1 \\
-1,7\end{array}$ \\
\hline 11 & $-3,5$ & $-5,1$ & $-2,1$ & 2,9 & 9,4 & 14,0 & 17,7 & 17,1 & 12,3 & 7,4 & 2,3 & $-1,8$ \\
\hline 12 & $-3,6$ & $-5,0$ & $-1,9$ & 3,1 & 9,6 & 14,1 & 17,8 & 17,0 & 12,1 & 7,2 & 2,2 & $-1,9$ \\
\hline 13 & $-3,6$ & $-5,0$ & $-1,8$ & 3,3 & 9,8 & 14,3 & 17,9 & 16,8 & 11,9 & 7,1 & 2,0 & $-1,9$ \\
\hline 14 & $\begin{array}{l}-3,7 \\
-1,7\end{array}$ & $-5,0$ & $\begin{array}{l}-1,6 \\
\end{array}$ & 3,5 & 10,0 & 14,4 & 17,9 & 16,7 & 11,7 & 6,9 & 1,8 & $-2,0$ \\
\hline 15 & $-3,8$ & $-4,9$ & $-1,5$ & 3,7 & 10,2 & 14,5 & 18,0 & 16,6 & 11,6 & 6,8 & 1,6 & $-2,1$ \\
\hline 16 & $-3,9$ & $-4,8$ & $-1,3$ & 3,9 & $\begin{array}{l}10,4 \\
\end{array}$ & 14,6 & 18,1 & 16,4 & 11,4 & 6,6 & 1,5 & $-2,1$ \\
\hline 17 & $-4,0$ & $-4,8$ & $-1,2$ & 4,1 & $\begin{array}{l}10,5 \\
10,\end{array}$ & $\begin{array}{l}14,0 \\
14,8\end{array}$ & 18,1 & 16,3 & 11,2 & 6,5 & 1,3 & $-2,2$ \\
\hline 18 & $-4,0$ & $-4,7$ & $-1,0$ & 4,3 & 10,7 & 14,9 & 18,2 & 16,2 & 11,1 & 6,3 & 1,1 & $-2,2$ \\
\hline 19 & $-4,1$ & $-4,6$ & $-0,9$ & 4,5 & 10,9 & 15,0 & 18,2 & 16,0 & 10,9 & 6,2 & 1,0 & $-2,3$ \\
\hline 20 & $-4,2$ & $-4,5$ & $-0,7$ & 4,8 & 11,0 & 15,2 & 18,2 & 15,9 & 10,7 & 6,0 & 0,8 & $-2,3$ \\
\hline 21 & $\begin{array}{l}-4,2 \\
-4,3\end{array}$ & $\begin{array}{l}-4,4 \\
-4,4\end{array}$ & $-0,6$ & $\begin{array}{l}4,0 \\
5,0\end{array}$ & 11,2 & $\begin{array}{l}15,2 \\
15,3\end{array}$ & $\begin{array}{l}18,2 \\
18,2\end{array}$ & 15,7 & $\begin{array}{l}10,6 \\
10,6\end{array}$ & $\begin{array}{l}5,0 \\
5,8\end{array}$ & 0,6 & $\begin{array}{l}-2,4 \\
-2,\end{array}$ \\
\hline 22 & $-4,4$ & $-4,3$ & $-0,4$ & 5,2 & 11,4 & 15,4 & 18,3 & 15,6 & 10,4 & 5,7 & 0,5 & $-2,4$ \\
\hline 23 & $-4,4$ & $-4,2$ & $-0,3$ & 5,4 & 11,5 & 15,6 & 18,3 & 15,4 & 10,2 & 5,5 & 0,3 & $-2,5$ \\
\hline 24 & $-4,5$ & $-4,1$ & $-0,1$ & 5,7 & 11,7 & 15,7 & 18,3 & 15,3 & 10,1 & 5,4 & 0,2 & $-2,5$ \\
\hline 25 & $\begin{array}{l}-4,6 \\
\end{array}$ & $-4,0$ & $\begin{array}{r}-, 1 \\
0,0\end{array}$ & 5,9 & 11,8 & 15,8 & $\begin{array}{l}18,3 \\
18,3\end{array}$ & 15,1 & $\begin{array}{r}9,1 \\
9,9\end{array}$ & $\begin{array}{l}\text {, } \\
5,2\end{array}$ & $\begin{array}{l}0,2 \\
0,0\end{array}$ & $\begin{array}{l}-2,5 \\
-2,5\end{array}$ \\
\hline 26 & $-4,7$ & $-3,9$ & 0,2 & 6,1 & 11,9 & 16,0 & 18,2 & 14,9 & 9,7 & 5,1 & $-0,1$ & $-2,6$ \\
\hline 27 & $-4,7$ & $-3,8$ & 0,3 & 6,3 & 12,1 & 16,1 & 18,2 & 14,8 & 9,6 & 4,9 & $-0,3$ & $-2,6$ \\
\hline 28 & $-4,8$ & $-3,6$ & 0,5 & 6,6 & 12,2 & 16,2 & 18,2 & 14,6 & 9,4 & 4,7 & $-0,4$ & $-2,7$ \\
\hline 29 & $\begin{array}{l}-4,8 \\
-4,8\end{array}$ & $-3,6$ & 0,7 & $\begin{array}{l}6,8 \\
6,8\end{array}$ & $\begin{array}{l}2,2 \\
12,4\end{array}$ & 16,4 & 18,1 & 14,4 & $\begin{array}{l}9,7 \\
9,2\end{array}$ & $\begin{array}{l}4,6 \\
4,6\end{array}$ & $\begin{array}{l}-0,7 \\
-0,5\end{array}$ & $-2,7$ \\
\hline 30 & $\begin{array}{l}-4,9 \\
\end{array}$ & & 0,8 & 7,0 & 12,5 & 16,5 & 18,1 & 14,3 & 9,1 & 4,4 & $\begin{array}{l}-0,7 \\
\end{array}$ & $-2,8$ \\
\hline 31 & $-5,0$ & & 1,0 & & 12,6 & & 18,0 & 14,1 & & 4,2 & & $-2,8$ \\
\hline
\end{tabular}

Vuorokauden tasoitetut keskilämpötilat vuoden kaikille päiville 30-vuotisjaksona 1981-2010 kahdella paikkakunnalla Suomessa. Kesä (kun lämpötila on korkeampi kuin $10^{\circ}$ ) on merkitty valkoisella, kevät ja syksy (kun lämpötila on $0-10^{\circ}$ ) vaaleanhar-
Viime vuosisadalla Zacharias Topelius määritteli Suomen vuodenajat hieman toisin. Hänen mukaansa marras- ja joulukuu ovat syystalvea, tammi- ja helmikuu sydäntalvea ja maalis- ja huhtikuu kevättalvea. Näin talven kestoksi laskettiin peräti kuusi kuukautta. Muille vuodenajoille jäikin sitten vain kaksi kuukautta kullekin: touko- ja kesäkuu ovat kevättä, heinä- ja elokuu kesää ja syys- ja lokakuu syksyä.

Tarkkoja rajoja vuodenajoille ei kuitenkaan voi vetää, ja eri maissa niillä voi olla eri paikat. Eteläisellä pallonpuoliskolla on tietysti kesä kun meillä on talvi ja syksy kun meillä on kevät, ja päinvastoin. Englannissa taas esimerkiksi ajatellaan kevään käsittävän helmi-, maalis- ja huhti-

\section{Sodankylä}

\begin{tabular}{|c|c|c|c|c|c|c|c|c|c|c|c|c|}
\hline Päivä & 它 & 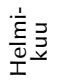 & 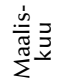 & 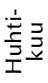 & 容部 & 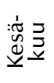 & 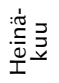 & 입르 & 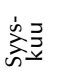 & 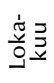 & 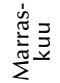 & 紊予 \\
\hline 1 & $-12,7$ & $-13,9$ & $-10,5$ & $-4,3$ & 2,0 & 8,8 & 14,0 & 13,9 & 9,0 & 3,2 & $-3,6$ & $-10,3$ \\
\hline 2 & $-12,8$ & $-13,9$ & $-10,4$ & $-4,1$ & 2,2 & 9,0 & 14,1 & 13,8 & 8,8 & 3,1 & $-3,9$ & $-10,4$ \\
\hline 3 & $-12,9$ & $-13,8$ & $-10,2$ & $-3,9$ & 2,4 & 9,2 & 14,2 & 13,6 & 8,6 & 2,9 & $-4,1$ & $-10,5$ \\
\hline 4 & $-12,9$ & $-13,8$ & $-10,0$ & $-3,7$ & 2,6 & 9,4 & 14,3 & 13,5 & 8,4 & 2,7 & $-4,4$ & $-10,7$ \\
\hline 5 & $-13,0$ & $-13,8$ & $-9,8$ & $-3,5$ & 2,9 & 9,7 & 14,4 & 13,4 & 8,2 & 2,5 & $-4,6$ & $-10,8$ \\
\hline 6 & $-13,0$ & $-13,7$ & $-9,6$ & $-3,3$ & 3,1 & 9,9 & 14,5 & 13,3 & 8,0 & 2,3 & $-4,9$ & $-10,9$ \\
\hline 7 & $-13,1$ & $-13,6$ & $-9,3$ & $-3,1$ & 3,3 & 10,1 & 14,5 & 13,1 & 7,8 & 2,1 & $-5,1$ & $-11,0$ \\
\hline 8 & $-13,1$ & $-13,6$ & $-9,1$ & $-2,9$ & 3,5 & 10,3 & 14,6 & 13,0 & 7,6 & 1,9 & $-5,4$ & $-11,1$ \\
\hline 9 & $-13,2$ & $-13,5$ & $-8,9$ & $-2,7$ & 3,8 & 10,5 & 14,6 & 12,9 & 7,4 & 1,7 & $-5,7$ & $-11,2$ \\
\hline 10 & $-13,3$ & $-13,4$ & $-8,7$ & $-2,5$ & 4,0 & 10,7 & 14,7 & 12,7 & 7,2 & 1,5 & $-5,9$ & $-11,3$ \\
\hline 11 & $-13,3$ & $-13,3$ & $-8,5$ & $-2,3$ & 4,2 & $\begin{array}{l}10,9 \\
\end{array}$ & 14,7 & 12,6 & 7,1 & 1,3 & $-6,2$ & $-11,4$ \\
\hline 12 & $-13,4$ & $-13,2$ & $-8,3$ & $-2,1$ & 4,4 & 11,1 & 14,7 & 12,4 & 6,9 & 1,0 & $-6,4$ & $-11,5$ \\
\hline 13 & $-13,4$ & $-13,1$ & $-8,1$ & $-1,8$ & 4,6 & 11,3 & 14,8 & 12,3 & 6,7 & 0,8 & $-6,6$ & $-11,6$ \\
\hline 14 & $-13,5$ & $-13,0$ & $-7,9$ & $-1,6$ & 4,9 & 11, & 14,8 & 12,1 & 6,5 & 0,6 & $\begin{array}{l}-6,9 \\
\end{array}$ & $-11,7$ \\
\hline 15 & $-13,5$ & $-12,9$ & $-7,7$ & $-1,4$ & 5,1 & 11,6 & 14,8 & 12,0 & 6,3 & 0,4 & $-7,1$ & $-11,8$ \\
\hline 16 & $-13,6$ & $-12,7$ & $-7,5$ & $-1,2$ & 5,3 & $11, \varepsilon$ & 14,8 & 11,8 & 6,1 & 0,2 & $-7,4$ & $-11,8$ \\
\hline 17 & $-13,6$ & $-12,6$ & $-7,3$ & -1, & 5,5 & 12 & 14,8 & & 5,9 & 0,0 & $-7,6$ & $-11,9$ \\
\hline 18 & $-13,7$ & $-12,4$ & $-7,1$ & $-0,8$ & 5,7 & 12,2 & 14,8 & 11,5 & 5,7 & $-0,2$ & $-7,8$ & $-12,0$ \\
\hline 19 & $-13,7$ & $-12,3$ & $-6,9$ & $-0,6$ & 6,0 & 12 & 14,7 & 11, & 5,5 & $-0,5$ & $-8,0$ & $-12,0$ \\
\hline 20 & $-13,8$ & $-12,1$ & $-6,7$ & -0 & 6,2 & 12, & 14,7 & 11 & 5,3 & $-0,7$ & $-8,2$ & $-12,1$ \\
\hline 21 & $\begin{array}{r}-13,8 \\
\end{array}$ & $\begin{array}{l}-12, \\
\end{array}$ & $-6,5$ & $-0,2$ & 6,4 & 12, & 14,7 & 11,0 & 5,2 & $-0,9$ & $-8,5$ & $-12,1$ \\
\hline 22 & $\begin{array}{l}-13,8 \\
\end{array}$ & $-11,8$ & $\begin{array}{l}-6,3 \\
\end{array}$ & 0,0 & 6,6 & 12, & 14,6 & 10,8 & 5,0 & $-1,2$ & $-8,7$ & $-12,2$ \\
\hline 23 & $-13,9$ & -11, & $-6,1$ & 0 & 6,8 & 13, & 14,6 & 10, & 4,8 & $-1,4$ & $-8,9$ & $-12,3$ \\
\hline 24 & -13, & -11 & -5 & & 7,1 & & 14 & & 4,6 & $-1,6$ & $-9,1$ & $-12,3$ \\
\hline 25 & $\begin{array}{r}-13,9 \\
\end{array}$ & $-11,3$ & $\begin{array}{l}-5,7 \\
\end{array}$ & 0,7 & 7,3 & 13, & 14,5 & 10,3 & $\begin{array}{l}\text {, } \\
4,4\end{array}$ & $\begin{array}{l}-1,9 \\
\end{array}$ & $-9,3$ & $-12,4$ \\
\hline 26 & $-13,9$ & -11 & $-5,5$ & 0,9 & 7,5 & 13 & 14,4 & 10,1 & 4,2 & $-2,1$ & $-9,4$ & $-12,4$ \\
\hline 27 & $-13,9$ & $-10,9$ & $-5,3$ & 1,1 & 7,7 & 13, & 14,3 & 9,9 & 4,0 & $-2,4$ & $-9,6$ & $-12,5$ \\
\hline 28 & $-13,9$ & -10 & $-5,1$ & 1,3 & 7,9 & 13 & 14 & 9, & 3,8 & $-2,6$ & $-9,8$ & $-12,5$ \\
\hline 29 & $-13,9$ & $-10,6$ & $-4,9$ & 1,6 & 8,2 & 13,8 & 14,2 & 9,5 & 3,6 & $-2,9$ & $-9,9$ & $-12,6$ \\
\hline 30 & $-13,9$ & & $-4,7$ & 1,8 & 8,4 & 13,9 & 14,1 & 9,3 & 3,4 & $-3,1$ & $-10,1$ & $-12,6$ \\
\hline 31 & $-13,9$ & & $-4,5$ & & 8,6 & & 14,0 & 9,1 & & $-3,4$ & & $-12,7$ \\
\hline
\end{tabular}

maalla ja talvi (lämpötila alle nollan) tummemmalla harmaalla. Taulukot on laadittu Helsingin yliopiston almanakkatoimistossa ja ne perustuvat Ilmatieteen laitoksen mittauksiin. 
kuun, kesän touko-, kesä-, heinä- ja elokuun, syksyn syys- ja lokakuun ja talven marras-, joulu- ja tammikuun.

Säätieteilijät puhuvat termisestä talvesta, kun keskilämpötila on alle nollan, termisestä keväästä kun lämpötila on 0 ja 10 asteen välillä, kesästä kun lämpötila on yli $10^{\circ}$ ja syksystä kun keskilämpötila on 10 ja 0 asteen välillä.

Oheisiin taulukoihin on laskettu tasoitettuja päivälämpötiloja Suomen paikkakunnille. Mittaukset on tehty viimeisimmän 30-vuotisen jakson eli vuosien 1981-2010 aikana. Taulukossa ei ole todellisia vuorokauden keskilämpötiloja, koska ne voivat heilahdella parikin astetta jonkin yksittäisen vuoden ennätyspakkasen tai löhöhelteen takia. Tasoitetut päiväkeskiarvot antavat paremman ennusteen sille, millainen lämpötila kullakin päivällä todennäköisimmin pitäisi olla.

Taulukot on laskettu kahdelle paikkakunnalle, joista toinen on EteläSuomessa (Helsinki) ja toinen Pohjois-Suomessa (Sodankylä).

Taulukot kertovat, että talvi vaihtuu kevääksi (eli lämpötila nousee nollan yli) Helsingissä maaliskuun 25. päivän paikkeilla ja Sodankylässä lähes kuukautta myöhemmin eli 22.4. Kesä alkaa Helsingissä keskimäärin toukokuun 14. päivänä ja Sodankylässä kesäkuun 7. päivänä.

Lämpötila pysyttelee kymmenen asteen paremmalla puolella Helsingissä syyskuun 25. päivään asti. Tällöin kesä siis vaihtuu syksyksi. Sodankylässä kesä kestää kuukautta vähemmän ja syksy alkaa elokuun 27. päivän paikkeilla.

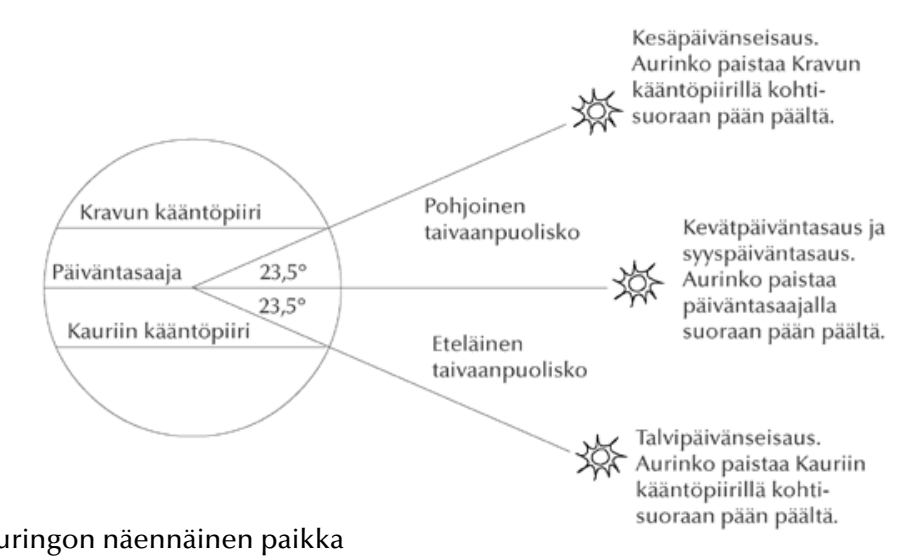

Auringon näennäinen paikk

maapallon taivaalla vuoden eri aikoina.
Syksyn pituus on Helsingissä runsaat kaksi kuukautta, ja talvi alkaa Etelä-Suomessa keskimäärin marraskuun 26. päivänä. Sodankylässä talven alkamispäivä on noin lokakuun 18:s.

Kirjamme ensimmäisissä painoksissa oli taulukot vuosille 1961-1990. Kun uudempia taulukoita verrataan niihin, huomataan ilmaston lämpenemisen selvä vaikutus. Talvi on Helsingissä lyhentynyt yli viikolla. Kesä on lähes viikon entistä pitempi ja se on siirtynyt muutaman päivän aikaisemmaksi. Sekä Helsingissä että Sodankylässä talven kylmyys on lauhtunut asteen tai puolitoista.

\section{Tähtitieteelliset vuodenajat}

Tähtitieteilijöillä on kaikkein tarkimmat määritelmät eri vuodenajoille, ja ne pätevät kaikkialla maapallolla. Tähtitieteellinen kevät alkaa kevätpäiväntasauksesta ja jatkuu kesäpäivänseisaukseen. Vastaavasti tähtitieteellinen kesä tarkoittaa aikaa kesäpäivänseisauksesta syyspäiväntasaukseen, syksy siitä talvipäivänseisaukseen ja talvi aikaa talvipäivänseisauksesta kevätpäiväntasaukseen.

Koska tasaus- ja seisaushetket voidaan laskea minuutin tarkkuudella, voidaan tähtitieteellisille vuodenajoille ilmoittaa hyvin tarkat pituudet, jotka pysyvät lähes muuttumattomina vuodesta toiseen. Kevät on 92,76 vuorokauden pituinen, kesä 93,65 vuorokauden, syksy 89,84 ja talvi 88,99 vuorokauden pituinen. Pienet erot eri vuodenaikojen pituuksissa

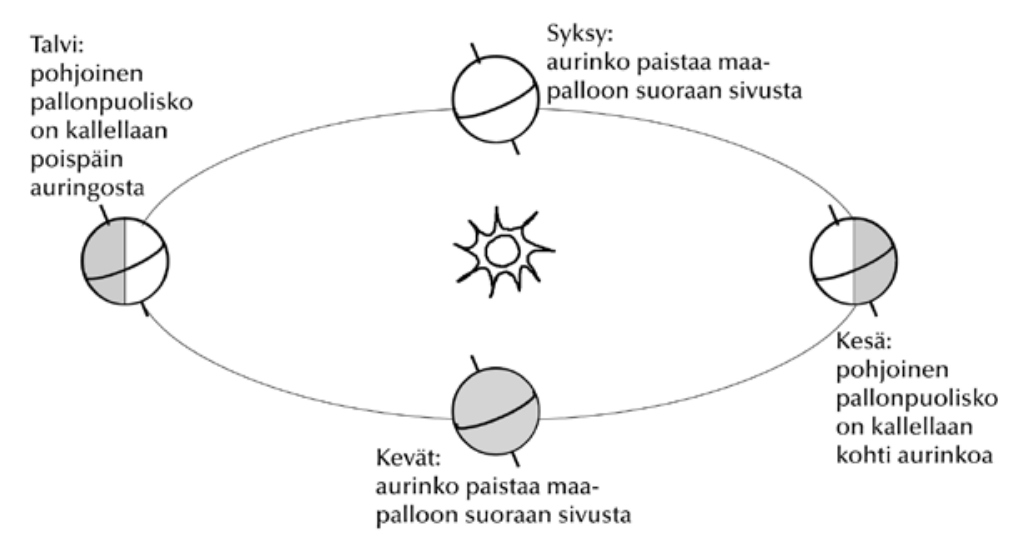

Vuodenaikojen vaihtelu. Maapallo kiertää aurinkoa kallellaan ja pysyy koko ajan samassa asennossa. 


\begin{tabular}{|c|c|c|c|c|c|c|c|}
\hline Vuosi & Tammi Helmi & Maalis Huhti Touko & Kesä & Heinä Elo & Syys & Loka Marra & is Joulu \\
\hline tavallisessa puheessa & Talvi & Kevät & & Kesä & & Syksy & Talvi \\
\hline zäätieteilijöillä (Hki) & Talvi & Kevät & & Kesä & & Syksy & Talvi \\
\hline ähtitieteilijöillä & Talvi & Kevät & & Kesä & & Syksy & \\
\hline
\end{tabular}

Vuodenajat eri tavoin määriteltyinä. Säätieteilijöiden vuodenajat on merkitty Helsingin lämpötilojen mukaan, muilla paikkakunnilla ajat ovat hieman toisenlaiset.

johtuvat maapallon radan epäkeskisyydestä: talvella maapallo kulkee vähän nopeammin, kun se on radallaan lähinnä aurinkoa, kesällä taas vähän hitaammin.

Kevätpäiväntasaus sattuu nykyään maaliskuun 20. tai 21. päivän kohdalle. Se on täsmällisesti sanottuna se ajanhetki, jolloin aurinko siirtyy eteläiseltä taivaanpuoliskolta pohjoiselle. Kevätpäiväntasauksen hetkellä aurinko paistaa päiväntasaajalla suoraan ylhäältäpäin.

Kevätpäiväntasausta sanotaan yleisesti siksi hetkeksi, jolloin yö ja päivä ovat yhtä pitkät. Tarkat almanakan lukijat ovat kuitenkin huomanneet, että auringon nousu- ja laskuaikojen mukaan päivä on yhtä pitkä kuin yö jo pari kolme vuorokautta ennen kevätpäiväntasausta.

Yö ja päivä olisivat kevätpäiväntasauksen hetkellä yhtä pitkät, jos maapallolla ei olisi ilmakehää ja jos aurinko olisi pistemäinen valolähde. Ilmakehässä valo kuitenkin taittuu tiheämpiin ilmakerroksiin päin, ja tämä nostaa taivaanrannassa olevan auringon kuvaa auringon läpimitan verran ylöspäin. Kun me näemme auringon juuri nousseen kokonaan, geometrisesti katsottuna alkaa vasta sen yläreuna olla taivaanrannassa.

Auringon suuri koko siirtää sen nousuajat myös pari minuuttia aikaisemmaksi. Nousut lasketaan nimittäin auringon yläreunan eikä keskipisteen mukaan. Ennen oli tapana laskea auringon keskipisteen nousuaika, mutta keskipisteen noustessa ovat auringon yläosat jo hyvän tovin valaisseet maisemaa.

Alkaneella vuosisadalla vaeltaa kevätpäiväntasaus hiljakseen aikaisemmaksi. Vuodesta 2016 alkaen se on joka vuosi maaliskuun 20. päivänä, ja vuodesta 2052 alkaen se voi olla jopa maaliskuun 19. päivänä. Kun vuonna 2100 jätetään karkauspäivä pitämättä, kevätpäiväntasaus hypähtää jälleen "normaalille" paikalleen maaliskuun 20. tai 21. päiväksi.

Kesäpäivänseisaus tarkoittaa sitä hetkeä, jolloin aurinko on kauimpana pohjoisella pallonpuoliskolla (Kravun kääntöpiirillä). Silloin

\section{Tasauspäivän uutta sisältöä Pysyykö muna pystyssä?}

1 uutama vuosi sitten Ultra-lehden toimittaja soitti Helsingin yliopiston tähtitieteen laitokselle. Hän oli lukenut ulkomailla tehdyistä kokeista, joissa oli yritetty saada kananmunaa seisomaan päällään. Kokeet näyttivät osoittavan, että muna pysyy helpoiten pystyssä, kun koe tehdään syyspäiväntasauksen tai kevätpäiväntasauksen aikaan. Toimittaja tiedusteli, onko ilmiölle mitään tieteellistä selitystä.

Pieni tutkimus muna-asiassa osoitti, että tällainen uusi uskomus tasauspäivän voimaan on ehkä 1980-luvulta lähtien saanut julkisuutta ns rajatieteiden harrastajien keskuudessa. Aihe pulpahtaa välillä esiin myös kevyemmissä tiedotusvälineissä tasauspäivien aikoihin.

Totuus on, että asiassa ei ole mitään perää. Tasaushetki, jolloin aurinko ylittää päiväntasaajan, ei millään tavoin pysty auttamaan munan pystyssäpysymiseen. Idea on luultavasti lähtenyt liikkeelle tasaus-sanasta: tasauspäivän on arveltu "tasaavan" painovoimaa tai auttavan tasapainon saavuttamisessa. Fysikaalista perustetta ilmiölle ei ole.

Munakokeet ovat olleet sellaisten harrastajien tekemiä, joilla ei ole ollut käsitystä tieteellisten kokeiden vaatimuksista. Jos joku on saanut munan pystyyn tasauspäivänä, hän on pitänyt koetta ideansa todisteena eikä ole tehnyt esimerkiksi samaa koetta vuoden kaikkina päivinä.

(Munan pystyyn saamiseen ei taida olla kuin yksi varma keino, se jota Kolumbuksen kerrotaan käyttäneen: muna napautetaan pöytään sen verran voimakkaasti, että kuori hieman rikkoutuu. Silloin muna jää pystyyn. Suosittelemme, että kokeessa käytetään keitettyä munaa.)

Myös kirkko on viime aikoina antanut tasauspäiville uutta sisältöä ja huomattavasti mielekkäämmällä tavalla kuin munanpystyttäjät. Kirkon piirissä järjestetään tasausten aikaan keräyksiä ja tempauksia, joilla muistutetaan siitä, että elämän antimet eivät ole jakautuneet tasan maapallon ihmisten kesken. Seurakunnat ovat yhteistyössä Suomen Lähetysseuran kanssa myyneet mm. tasauspäivän leipiä, joiden tuotto on mennyt lyhentämättömänä afrikkalaisten naisten aseman parantamiseen tai pakistanilaissairaalan kunnostamiseen. Yhden tasauspäivän tuotto on voinut olla jopa satojatuhansia euroja.

meillä on päivä pisimmillään. Käytännössä neljä viisi päivää kesäpäivänseisauksen ympärillä ovat minuutilleen yhtä pitkiä, ennen kuin päivät alkavat lyhetä. Jos nousu- ja laskuajat laskettaisiin sekunnin tarkkuudella, olisi pisin päivä nimenomaan se, jolle kesäpäivänseisaus sattuu. 
Kesäpäivänseisaus osuu näinä aikoina joka vuosi kesäkuun 21. päivälle. Vuodesta 2024 alkaen päivämäärä voi olla myös 20.6.

Syyspäiväntasauksen hetkellä aurinko siirtyy taas päiväntasaajan pohjoispuolelta sen eteläpuolelle, ja yöt alkavat olla pitempiä kuin päivät. Samasta syystä kuin kevätpäiväntasauksen aikaan myös syyspäiväntasauksen hetki sattuu jo pari päivää ennen kuin yö ja päivä ovat almanakassa ilmoitettujen nousu- ja laskuaikojen mukaan yhtä pitkät.

Syyspäiväntasaus osuu nykyään syyskuun 22. tai 23. päivälle. Vuodesta 2076 vuosisadan loppuun päivämäärä on aina 22.9. Nämä päivämäärät, kuten muidenkin seisausten ja tasausten kohdalla mainitut päivämäärät, pitävät paikkansa Suomen ajan mukaan laskettuina. Muilla aikavyöhykkeillä päivämäärät ja niiden vaihtumisvuodet ovat hieman toisenlaiset.

Talvipäivänseisauksen päivämäärä on nykyään joko 21. tai 22. joulukuuta. Vuodesta 2052 vuosisadan loppuun asti päivämäärä on joka vuosi 21.12. Aurinko on talvipäivänseisauksen hetkellä kauimpana etelässä (Kauriin kääntöpiirillä) ja päivä on lyhimmillään - jos päivää ollenkaan tulee. Pohjois-Suomessahan ei aurinko nouse tähän aikaan lainkaan.

\section{Aurinko lähimpänä ja kauimpana}

Monilla on sellainen käsitys, että vuodenaikojen vaihtelu johtuu auringon ja maapallon välimatkan muuttumisesta. Tämä ei ole kuitenkaan oikea käsitys, sillä lähinnä aurinkoa maapallo on tammikuun alussa,

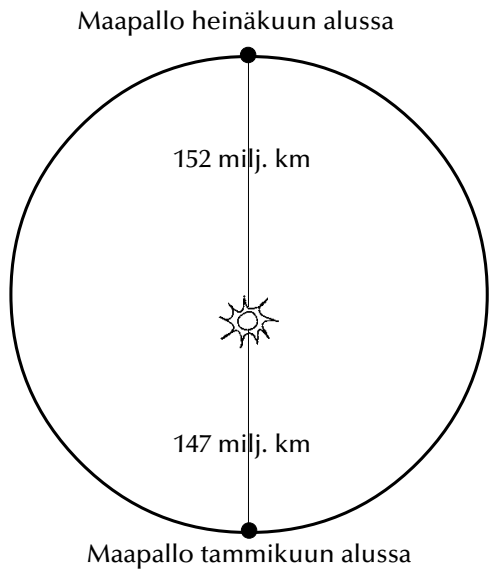

Maapallon rata auringon ympäri on epäkeskinen ympyrä. Lähinnä aurinkoa maa on tammikuun alussa ja kauimpana heinäkuun alussa. jolloin pohjoisella pallonpuoliskolla on täysi talvi. Vastaavasti kauimpana auringosta olemme heinäkuun alussa, jolloin täällä pohjoisessa on kaikkein lämpimintä. Etäisyyden aiheuttama lämpötilan vaihtelu toki voidaan huomata, mutta se on paljon pienempää kuin vuodenaikojen todellisen aiheuttajan, maapallon akselin kaltevuuden aiheuttama lämpötilanvaihtelu.

Auringon pienimmän etäisyyden päivämäärä ei ole täsmälleen sama joka vuosi, vaan siinä ilmenee parin päivän heilahteluja. Tämä johtuu pääasiassa kuun aiheuttamista maan liikkeen häiriöistä. Päivämäärissä tapahtuu lisäksi hyvin hidas vaellus eteenpäin. Kun 1990-luvulla maapallo oli lähinnä aurinkoa tammikuun 2.-4. päivänä, on vuoden 2050 paikkeilla päivämäärä yleensä 3.-5.1., ja kun ihmiskunta elää vuotta 2500, olemme lähinnä aurinkoa vasta tammikuun 10.-12. päivän paikkeilla.

Päivämäärän siirtyminen johtuu siitä, että maapallon akseli ei tarkkaan ottaen pysy aivan samassa suunnassa avaruudessa. Maapallo huojahtelee ympäri kuin suuri hyrrä, ja yhteen huojahdukseen kuluu aikaa noin 26000 vuotta. Tämän ajan kuluttua maapallon akseli on taas samassa suunnassa kuin lähtöhetkellä. Tähtitieteilijät kutsuvat huojuntaa nimellä prekessio.

Kalenterivuoden pituus määritellään kahden peräkkäisen kevättasauspisteen väliaikana, ja tämä väliaika on hieman eripituinen kuin aika aurinkoa lähinnä olevasta pisteestä seuraavaan lähinnä olevaan pisteeseen. Ero on noin 20 minuuttia, ja tämän verran lähin piste vaeltaa yhdessä vuodessa eteenpäin.

Auringon ja maapallon lyhimmän ja pisimmän välimatkan hetkiä ei pysty luonnosta tai taivaalta helposti havaitsemaan, ne löytyvät vain almanakan sivuilta. Yhtä huomaamattomia ovat auringon siirtymiset eri eläinradan merkkeihin. Koska niillä on kuitenkin ollut suuri merkitys astrologiassa eli tähdistäennustamisessa ja ne edelleen esiintyvät almanakoissa ja horoskoopeissa, on niitä syytä käsitellä vähän tarkemmin.

\section{Auringon liike eläinradalla}

Jos voisimme nähdä auringon ympärillä tähtiä, samaan tapaan kuin yöllä näemme tähtiä kuun ympärillä, huomaisimme, että aurinko vaeltaa vuodesta toiseen samojen tähtikuvioiden kautta. 
Auringon kulkureitti taivaalla sai jo kauan sitten nimen eläinrata. Myös kuu ja planeetat pysyttelevät aina tällä samalla vyöhykkeellä, vaikka voivatkin liikkua hieman auringon radan ala- tai yläpuolella.

Kaksituhatta vuotta sitten eläinradalla oli kaksitoista tähdistöä ja jokaiselle oli annettu yhtä pitkä kaista eläinradasta. Koska täysi ympyrä on 360 astetta, oli jokainen tähdistö 30 asteen pituinen.

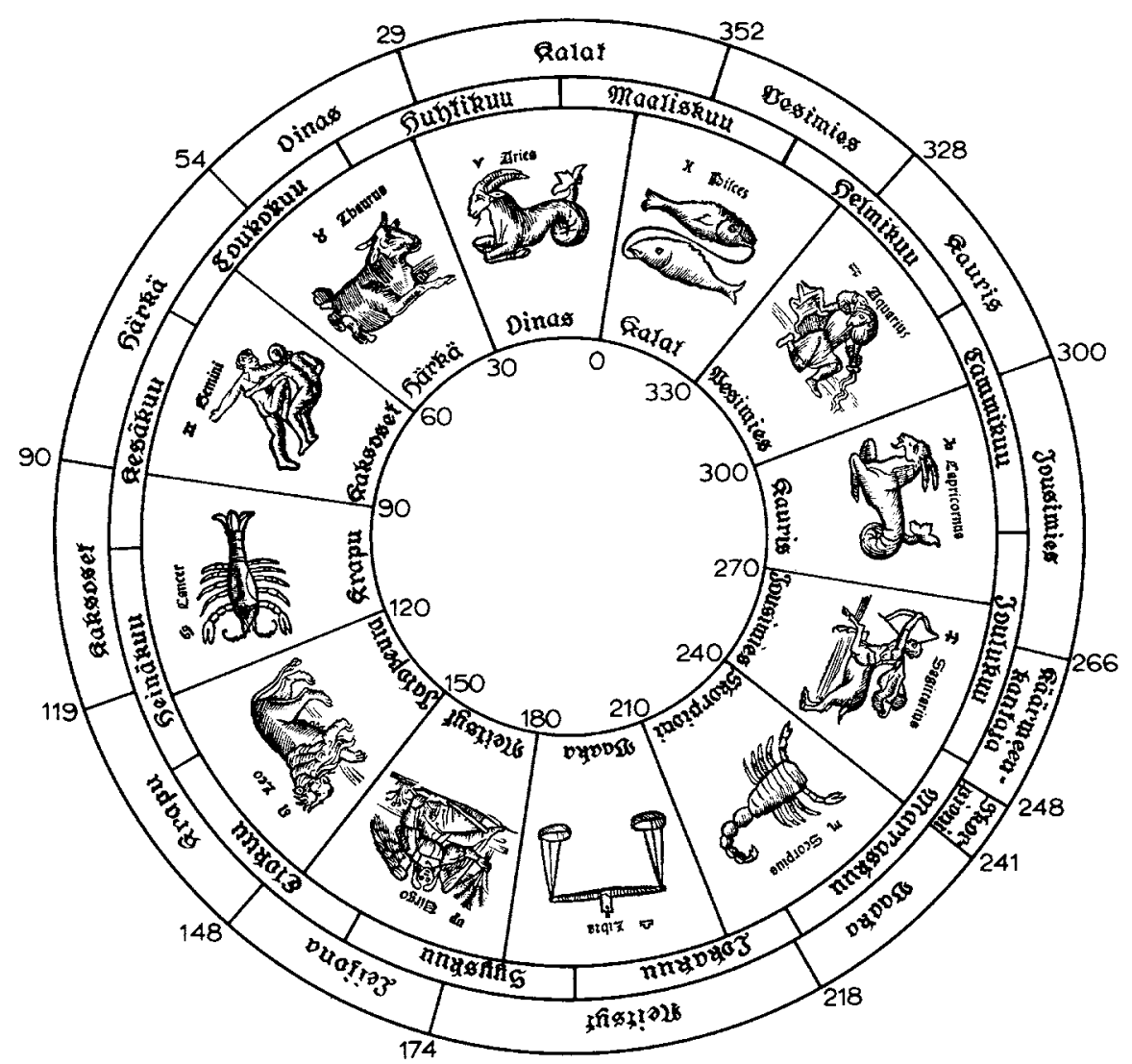

Auringon liike eläinradalla ympäri vuoden. Sisimmäksi on merkitty eläinradan vanhat tähdistöt, joista jokainen on 30 asteen pituinen. Uloimmaksi on merkitty eläinradan nykyiset tähdistöt ja niiden todelliset rajat. Kuviossa on myös kuukausien nimet. Niiden kohdalta voi lukea, missä tähdistössä aurinko kunakin hetkenä on. Esimerkiksi marraskuun lopulta joulukuun puoliväliin aurinko on Käärmeenkantajan tähdistössä. (Piirros on alun perin kirjasta 1982 kun planeetat kohtaavat, mutta tähdistöjen rajat on muutettu vastaamaan vuoden 2000 tilannetta.)
Esimerkiksi jokaisen maaliskuun 21. päivän tienoilla aurinko tuli Oinaan tähdistöön ja kuukautta myöhemmin Härän tähdistöön. Almanakka kertoo edelleen nämä vanhat päivämäärät.

Todellisuudessa tähdistöt ovat vaihtaneet paikkaa. Tähtitaivas on ehtinyt kahdessatuhannessa vuodessa muuttua melkoisesti. Muutamat tähdet ovat heikentyneet ja toiset kirkastuneet. Ja tähdistöjen rajat ovat siirtyneet.

Tähdistöjen rajojen muuttumiseen on ollut kaksi syytä. Ensimmäinen on maapallon akselin huojuminen, prekessio, joka vähitellen kuljettaa tähdistöjä pitkin eläinrataa. Kun aurinko oli ennen maaliskuun lopulla Oinaan tähdistössä, se on nykyään tähän aikaan Kalojen tähdistössä. Kahdentuhannen vuoden takaiset tähdistöt ovat vaeltaneet eläinradalla lähes 30 asteen päähän vanhoilta paikoiltaan.

Toinen syy tähtikuvioiden muuttumiseen on se, että tähtitaivas on nykyään jaettu eri tavalla tähdistöihin kuin kaksituhatta vuotta sitten. Kansainvälinen tähtitieteellinen liitto hyväksyi 1920-luvun lopulla uuden tähdistöjaon. Se merkitsi melkoista remonttia myös eläinradalla.

Entisen kahdentoista tähdistön tilalla eläinradalla on nykyään 13 tähdistöä. Niistä kaksitoista ovat vanhoja tuttuja, mutta kolmastoista on uusi, nimeltään Käärmeenkantaja. Samalla luovuttiin eläinradan tasajaosta, sillä taivas haluttiin jakaa osiin tähtisikermien omien luonnollisten rajojen mukaan.

Niinpä nykyiset eläinradan tähdistöt ovat hyvin eripituisia. Esimerkiksi Skorpioni on vain seitsemän asteen pituinen, Käärmeenkantaja 18 asteen ja Neitsyt peräti 44 asteen pituinen.

Oheiseen piirrokseen on merkitty vertailun vuoksi vanhat eläinradan merkit ja nykyiset eläinradan tähdistöt, joiden kautta aurinko vuoden mittaan vaeltaa. Piirroksesta nähdään, että horoskooppimerkit poikkeavat samannimisistä tähdistöistä noin kuukaudella.

Tulevaisuudessa merkit ja tähdistöt siirtyvät yhä kauemmas toisistaan. Kuviossa tämä näkyy niin, että uloin kehä (tähdistöt) kiertyy hiljalleen vastapäivään sisemmän kehän suhteen. Asko Palviaisen laskujen mukaan esimerkiksi Kauriin ja Vesimiehen merkkien välinen raja (auringon pituus 300 astetta) siirtyy Jousimiehen tähdistöön vuonna 2025. Seuraavaksi Oinaan ja Härän raja (30 astetta) siirtyy Kaloihin vuonna 2094 ja Kravun ja Jalopeuran raja (120 astetta) siirtyy Kaksosten tähdistöön vuonna 2144. 


\section{Kaamos ja yöttömät yöt}

Sän ja lämpötilan vaihtelun ohella on valoisuuden vaihtelu selvin mittari vuodenaikojen muuttumiselle. Koko Suomessa päivä pitenee keväällä yli viisi minuuttia joka vuorokausi. Etelä-Suomessa päivän piteneminen hidastuu kesää kohti, mutta Pohjois-Suomessa päivä saa selkävoiton pimeydestä ja siellä päästään viettämään yöttömiä öitä ja ihailemaan keskiyön aurinkoa.

Teoreettinen raja keskiyön auringon - tai ainakin sen yläreunan - näkymiselle kulkee hieman Kemin eteläpuolelta. Jos maapallolla ei olisi ilmakehää ja aurinko olisi pistemäinen, raja olisi napapiirillä, jonka leveysaste on noin $66,5^{\circ}$. Mutta valon taipuminen ilmakehässä ja auringon suuri koko siirtävät rajan lähes asteen (tarkemmin sanottuna 51 kaariminuuttia) etelämmäksi. Siksi Kemissä voidaan katsella keskiyön aurinkoa lähes viikon verran kesäpäivänseisauksen tienoilla.

Suomen pohjoiskärjessä Nuorgamissa kesäyön aurinko alkaa paistaa jo noin 16. päivänä toukokuuta. Yöttömän yön raja siirtyy etelämmäksi toukokuun ja kesäkuun edetessä. Oheisessa taulukossa on lueteltu kesäyön auringon keskimääräinen näkymisaika Pohjois-Suomen eri paikkakunnilla. Todellinen aika saattaa poiketa päivällä taulukon keskiarvoajoista. Kunkin vuoden tarkka taulukko löytyy Yliopiston almanakasta.

Nuorgamissa saadaan nauttia keskiyön auringosta heinäkuun loppupäiviin asti. Etelämpänä yöt alkavat pimetä jo aikaisemmin. Syyskuun lopulla päivän lyheneminen on nopeinta, ja marraskuun lopulta alkaen Lappiin alkaa levitä kaamos, jolloin aurinkoa ei näy edes päivällä.

Kun yöttömien öiden raja kulkee lähes asteen napapiiriä etelämpänä, kulkee vastaavasti kaamoksen raja lähes asteen napapiiriä pohjoisempana. Sodankylässsä ja sitä pohjoisempana on joulun aikaan aurinko "pesässään" eikä näyttäydy lainkaan. Viereisessä taulukossa on annettu myös kaamoksen kestoaika eri paikkakunnilla.

\section{Valo ja energia maapallon eri puolilla}

Valoisuuden vaihteluun eri aikoina ja eri paikkakunnilla liittyy pari mielenkiintoista kysymystä. Ensimmäinen koskee päivän pituutta eri puolilla maapalloa. Helsingin yliopiston tähtitieteen laitokselta on useaan otteeseen kysytty, saavatko kaikki seudut maapallolla yhtä paljon valoa,

\section{cesäyön aurinko ja kaamos}

apissa alkavat toukokuussa yöttömät yöt, jolloin aurinko ei laske lainL kaan. Kesäyön auringon alku- ja loppupäivät ovat eri leveysasteilla keskimäärin seuraavat:

Paikkakunta alkupäivä loppupäivä

$\begin{array}{lll}\text { Nuorgam } & 16.5 . & 29.7 . \\ \text { Utsjoki } & 17.5 . & 28.7 . \\ \text { Kilpisjärvi } & 21.5 . & 24.7 . \\ \text { Inari } & 22.5 . & 23.7 . \\ \text { Ivalo } & 23.5 . & 22.7 . \\ \text { Muonio } & 27.5 . & 18.7 . \\ \text { Kolari } & 30.5 . & 14.7 . \\ \text { Sodankylä } & 30.5 . & 15.7 . \\ \text { Pello } & 4.6 . & 10.7 . \\ \text { Kemijärvi } & 4.6 . & 9.7 . \\ \text { Rovaniemi } & 6.6 . & 7.7 . \\ \text { Ylitornio } & 8.6 . & 6.7 . \\ \text { Posio } & 11.6 . & 2.7 . \\ \text { Kuusamo } & 13.6 . & 1.7 . \\ \text { Tornio } & 15.6 . & 29.6 . \\ \text { Kemi } & 19.6 . & 25.6 .\end{array}$

Pohjoisin Suomi joutuu vuoden lopulla olemaan ilman auringonpaistetta. Kaamosajan alku- ja loppupäivät ovat eri leveysasteilla keskimäärin seuraavat:

Paikkakunta alkupäivä loppupäivä

$\begin{array}{lll}\text { Nuorgam } & 25.11 . & 17.1 . \\ \text { Utsjoki } & 26.11 . & 16.1 . \\ \text { Kilpisjärvi } & 1.12 . & 12.1 . \\ \text { Inari } & 2.12 . & 11.1 . \\ \text { Ivalo } & 3.12 . & 9.1 . \\ \text { Muonio } & 9.12 . & 3.1 . \\ \text { Kolari } & 20.12 . & 24.12 . \\ \text { Sodankylä } & 20.12 . & 24.12 .\end{array}$


jos lasketaan valoisa aika koko vuoden ympäri. Vastaus on ehkä yllättäen se, että päivän pituus vuoden yli laskettuna on suurin napaseuduilla ja pienin päiväntasaajalla.

Miten tämä on selitettävissä? Almanakka merkitsee auringon nousut ja laskut auringon yläreunan mukaan eikä keskipisteen mukaan. Siksi (koko vuoden yli laskettuna) päivä on keskimäärin yötä pitempi kaikkialla maapallolla. Lisämuutosta tuo maapallon ilmakehä, koska se taittaa auringon valoa. Kuten aikaisemmin mainittiin, aivan taivaanrannassa ilmakehä nostaa auringon kuvaa suunnilleen auringon läpimitan verran. Tämä tuo kaikkialla vielä lisää pituutta päivään.

Päiväntasaajan lähellä aurinko nousee ja laskee hyvin pystysuoraan. Siksi ilmakehän aiheuttama muutos ei anna siellä valoisaan aikaan paljonkaan lisäminuutteja. Sen sijaan suurilla pohjoisilla ja eteläisillä leveysasteilla aurinko nousee ja laskee hyvin loivasti, ja siksi lisäminuutteja kertyy enemmän.

Ero näkyy jo Suomenkin mittakaavassa. Helsingissä päivän pituus on keskimäärin noin $12 \mathrm{~h} 30$ min ja yön pituus $11 \mathrm{~h} 30 \mathrm{~min}$. Utsjoella päivän pituus on keskimäärin 12 h 45 min eli vartin enemmän kuin

\section{Masentaako kaamos?}

Gomi on maapallon pohjoisimpia maita, ja siksi täällä on otollista tutkia kaamoksen vaikutusta ihmisten mielenterveyteen. Tutkimuksia on tehty niin Lapissa kuin esimerkiksi Jyväskylän ja Turun yliopistossa.

Kaamosmasennusta esiintyy tutkimusten mukaan noin kymmenesosalla suomalaisista ja vähäisempiä häiriöitä pimeään vuodenaikaan noin neljäsosalla kansastamme. Tavallisimpia kaamosmasennuksen oireita on mielialan laskeminen, toimintatarmon väheneminen ja väsyneisyys vaikka nukkuma-ajat voivat pidentyä. Ruokahalu voi kasvaa ja paino nousta.

Tutkimusten mukaan saamelaisilla on oireita selvästi vähemmän kuin suomalaisilla. Saamelaiset ovat kymmenien tai satojen sukupolvien ajan tottuneet elämään maailmassa, jossa vuodenaikojen erot ovat tavattoman suuret ja osan aikaa vuodesta aurinko on kokonaan piilossa.

Kaamosmasennuksen syynä pidetään valon määrän vähentymistä. Kirkasvalohoito auttaa selvästi oireisiin.

Jotkut lääkärit ovat sitä mieltä, että nykyisiin vuodenaikamasennuksiin ovat syynä enemmänkin yhteiskunnalliset tekijät kuin valon määrä. Esimerkiksi työttömyys lisää masennusta, tuiskusi tai paistoi.
Helsingissä ja yön pituus vastaavasti vartin lyhempi eli 11 h 15 min.

Toinen kysymys koskee auringosta tulevaa energiaa eri puolilla maapalloa. Vaikka napaseuduilla on pitkät yöttömät yöt, aurinko paistaa niiden aikana hyvin loivasti maan pintaan ja auringon valo joutuu kulkemaan pitkän matkan ilmakehän läpi. Näin sen teho heikkenee jo ennen maanpinnan saavuttamista.

Kasvien kehittyminen on verrannollinen mm. siihen energiamäärään, jonka maanpinta auringosta saa. Niinpä voimme laskea, kuinka paljon energiaa yksi neliömetri maapallon pintaa saa vuorokaudessa vuoden eri aikoina ja eri leveysasteilla. Laskuissa on otettava huomioon päivän pituus, säteilyn tulokulma ja säteilyn imeytyminen ilmakehään.

Laskut antavat mielenkiintoisen tuloksen, joka on ohessa esitetty käyrän muodossa. Päiväntasaajalla pinnan saama energia vaihtelee vain vähän vuoden eri aikoina ja pysyttelee aina kohtalaisen korkealla tasolla. Siksi siellä kasvaakin runsaita sademetsiä sellaisilla seuduilla, joissa kosteutta on riittävästi.

Suomen leveysasteilla pinnan saama energia on talvella hyvin vähäinen, ja siksi meillä lumi ja jää peittävät maan. Mutta kesän tullen energiamäärä kohoaa niin korkealle, että toukokuun lopulta heinäkuun lopulle Suomi saa joka vuorokausi enemmän auringon energiaa kuin

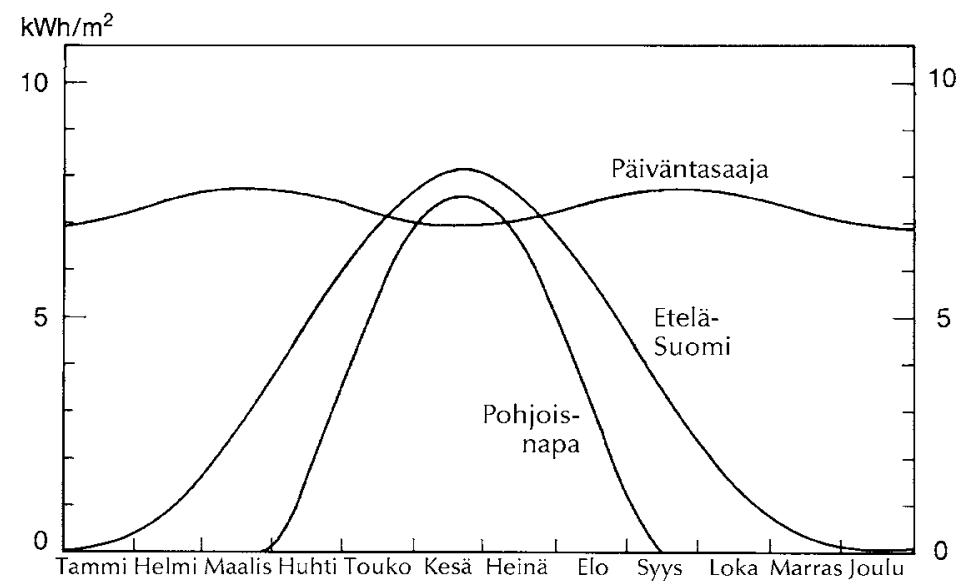

Käyrät kuvaavat maanpinnan saamaa auringon energiaa yhdessä vuorokaudessa eri aikoina vuotta päiväntasaajalla, Suomen leveysasteella $\left(60^{\circ}\right)$ ja pohjoisnavalla $\left(90^{\circ}\right)$ Suomi saa kesällä enemmän energiaa kuin päiväntasaajaseudut voivat koskaan saada. (Piirros on mukailtu Tähtitieteen perusteet -kirjasta.) 
päiväntasaajaseudut koskaan voivat saada. Siksi tällä kasvikunta puhkeaa kukoistukseen hurjalla vauhdilla ja ehtii lyhyenkin kesän aikana antaa hyvän sadon.

\section{Auringonpimennykset}

Auringon- ja kuunpimennykset ovat näyttävimpiä tähtitaivaan ilmiöitä. $\mathrm{Ne}$ ovat lisäksi verrattain harvinaisia, ja siksi niihin on kaikkina aikoina kiinnitetty suurta huomiota.

Pimennysten syyt ovat varmaan kaikille tutut. Kuten Uuden Suomen pakinoitsija Olli aikoinaan kirjoitti, "jos kuu joutuu maan ja auringon väliin, tulee auringonpimennys; jos maa joutuu kuun ja auringon väliin, tulee kuunpimennys; ja jos aurinko joutuu maan ja kuun väliin, tulee maailmanloppu".

Auringonpimennyksiä on kolmea eri tyyppiä: osittaisia, rengasmaisia ja täydellisiä. Yleensä auringonpimennys näkyy täydellisenä (tai rengasmaisena) kapealla kaistalla, joka kulkee maapallon pinnan yli, ja osittai-

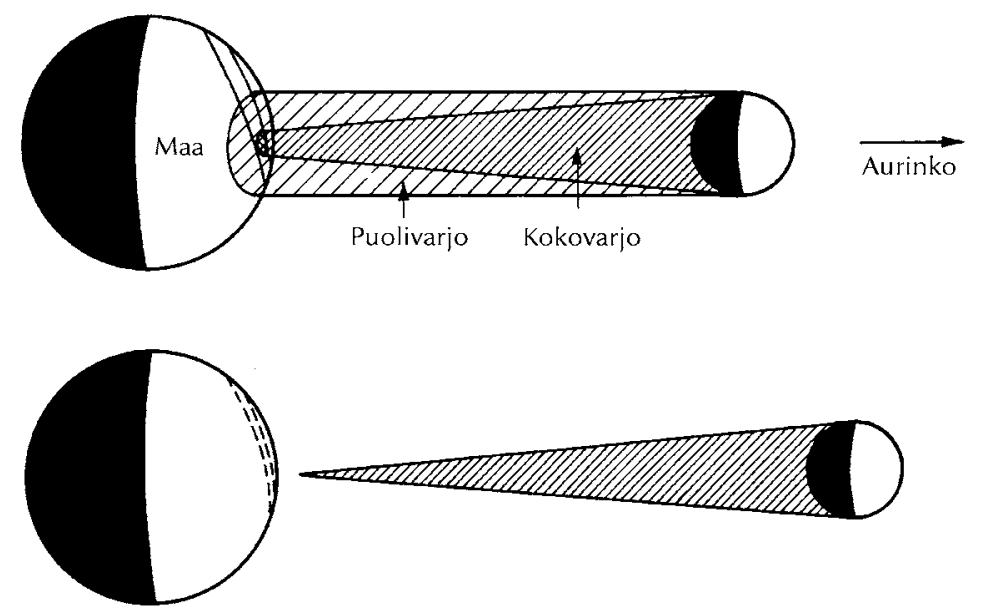

Auringonpimennys syntyy, kun kuu tulee auringon eteen. Kuu heittää maan pinnalle kokovarjon, josta aurinko ei näy lainkaan. Sen ympärillä maanpinnalla on puolivarjon alue, josta pimennys näkyy osittaisena. Rengasmainen auringonpimennys syntyy silloin, kun kuu on ratansa uloimmissa pisteissä eikä kokovarjo yletä maahan asti. Maan pinnalle ylettyy vain puolivarjo (jota ei ole piirretty kuvaan). (Piirrokset muokattu Tähtitieteen perusteet -kirjasta.) sena laajalla alueella täydellisyysvyöhykkeen ympärillä.

Rengasmainen auringonpimennys tarkoittaa tapausta, jossa aurinko paistaa joka puolelta kuun reunan yli. Tällainen sattuu silloin, kun kuu on pimennyshetkellä lähellä ratansa ulointa pistettä. Sen näennäinen läpimitta on silloin pienempi kuin auringon, ja siksi se ei peitä aurinkoa kokonaan.

Rengasmaisen pimennyksen sattuessa päivä ei paljon pimene. Sen sijaan täydellinen auringonpimennys merkitsee hetkellisen yön tuloa. Pimennys voi kestää 7-8 minuuttia, ja sen tullessa linnut lakkaavat laulamasta, ilma kylmenee ja hämärä peittää maan.

Osittaisella ja rengasmaisella auringonpimennyksellä on mielenkiintoa lähinnä tähtitieteen harrastajalle. Sen sijaan täydellinen pimennys oli varsinkin aikaisemmin huomattava tieteellinen tapahtuma. Sitä seuraamaan matkusti suuria tähtitieteellisiä retkikuntia, vaikka se olisi sattunut kaukaisilla, lähes luoksepääsemättömilläkin seuduilla.

Rengasmaiset ja täydelliset auringonpimennykset ovat verraten harvinaisia, ja niitä sattuu kullakin paikkakunnalla yleensä parinsadan vuoden välein. Osittaiset pimennykset ovat paljon tavallisempia, ja niitä sattuu keskimäärin parin vuoden välein.

Rengasmainen auringonpimennys. Kuu ei riitä peittämään koko aurinkoa. Suomessa nähdään seuraava rengasmainen pimennys vuonna 2039. (Kuva NOAO)

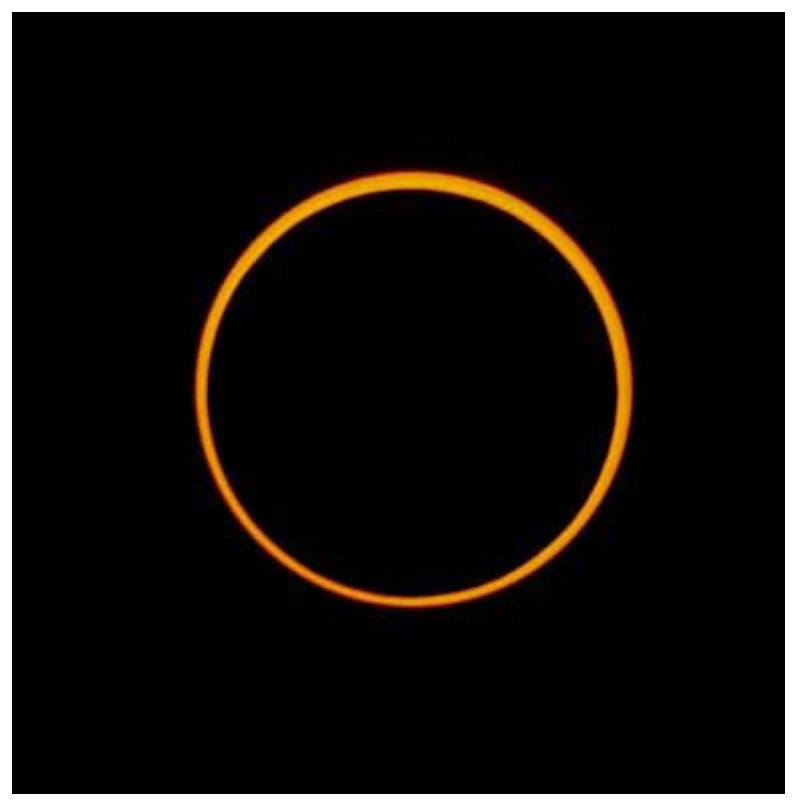




\section{Lähiajan pimennyksiä}

Täydellisiä $(T)$ ja rengasmaisia $(R)$ auringonpimennyksiä 2013-2019

$\begin{array}{rrl}\text { 10.5.2013 } & \text { R } & \text { Australia, Tyynimeri } \\ 3.11 .2013 & \mathrm{~T} & \text { Afrikka, Atlantti } \\ 20.3 .2015 & \mathrm{~T} & \text { Färsaaret, Huippuvuoret } \\ 9.3 .2016 & \mathrm{~T} & \text { Indonesia, Tyynimeri } \\ 1.9 .2016 & \mathrm{R} & \text { Afrikka, Madagaskar } \\ 26.2 .2017 & \mathrm{R} & \text { Etelä-Amerikka, Afrikka } \\ 21.8 .2017 & \mathrm{~T} & \text { Pohjois-Amerikka } \\ 2.7 .2019 & \mathrm{~T} & \text { Etelä-Amerikka } \\ 26.12 .2019 & \mathrm{R} & \text { Arabia, Intia, Indonesia }\end{array}$

\section{Suomessa näkyvät auringon- ja kuunpimennykset}

\section{3-2025}

Kuun puolivarjopimennyksiä ei ole mainittu, koska niitä on vaikea havaita lainkaan.

\begin{tabular}{|c|c|c|}
\hline 2013 & huhtikuun 25. & osittainen kuunpimennys \\
\hline 2015 & maaliskuun 20. & $\begin{array}{l}\text { osittainen auringonpimennys } \\
\text { (täydellinen Huippuvuorilla) }\end{array}$ \\
\hline 2015 & syyskuun 28. & täydellinen kuunpimennys \\
\hline 2017 & elokuun 7. & osittainen kuunpimennys \\
\hline 2018 & tammikuun 31. & täydellinen kuunpimennys \\
\hline 2018 & heinäkuun 27. & täydellinen kuunpimennys \\
\hline 2018 & elokuun 11. & osittainen auringonpimennys \\
\hline 2019 & tammikuun 21. & täydellinen kuunpimennys \\
\hline 2019 & heinäkuun 16. & osittainen kuunpimennys \\
\hline 2021 & kesäkuun 10. & $\begin{array}{l}\text { osittainen auringonpimennys } \\
\text { (rengasmainen Grönlannissa) }\end{array}$ \\
\hline 2021 & marraskuun 19. & osittainen kuunpimennys \\
\hline 2022 & lokakuun 25. & osittainen auringonpimennys \\
\hline 2023 & lokakuun 28. & osittainen kuunpimennys \\
\hline 2024 & syyskuun 18. & osittainen kuunpimennys \\
\hline 2025 & maaliskuun 29. & osittainen auringonpimennys \\
\hline 2025 & syyskuun 7. & täydellinen kuunpimennys \\
\hline
\end{tabular}

\section{Suomen pimennykset}

Sadan viime vuoden aikana on aurinko Suomessa pimentynyt täydellisesti neljä kertaa.

Vuoden 1927 pimennyksen keskiviiva kulki Enontekiön kirkolta Nuorgamiin. Pimennys näkyi klo 8:n maissa aamulla. Etelä-Suomessa sää oli pilvinen, mutta Lapissa oli onneksi selkeää.

Kolme muuta täydellistä pimennystä sattuivat Etelä-Suomessa. Elokuun 21. päivän 1914 pimennys, jota seuraavan aukeaman laatikossa selostetaan helsinkiläisten näkökulmasta, näkyi täydellisenä Raumalta Hankoon vedetyn viivan länsipuolella. Pimennysvyöhykkeen keskiviiva kulki Ahvenanmaan kautta, ja täydellisen vaiheen kesto oli siellä runsaat 2 minuuttia. Lounais-Suomessa sää oli selkeä, joten pimennystä päästiin siellä seuraamaan paremmin kuin Helsingissä.

Seuraava täydellinen pimennys sattui heinäkuun 9. päivänä 1945, ja täydellisyysvyöhyke kulki 80 km leveänä suunnilleen Kokkolan-Savon-

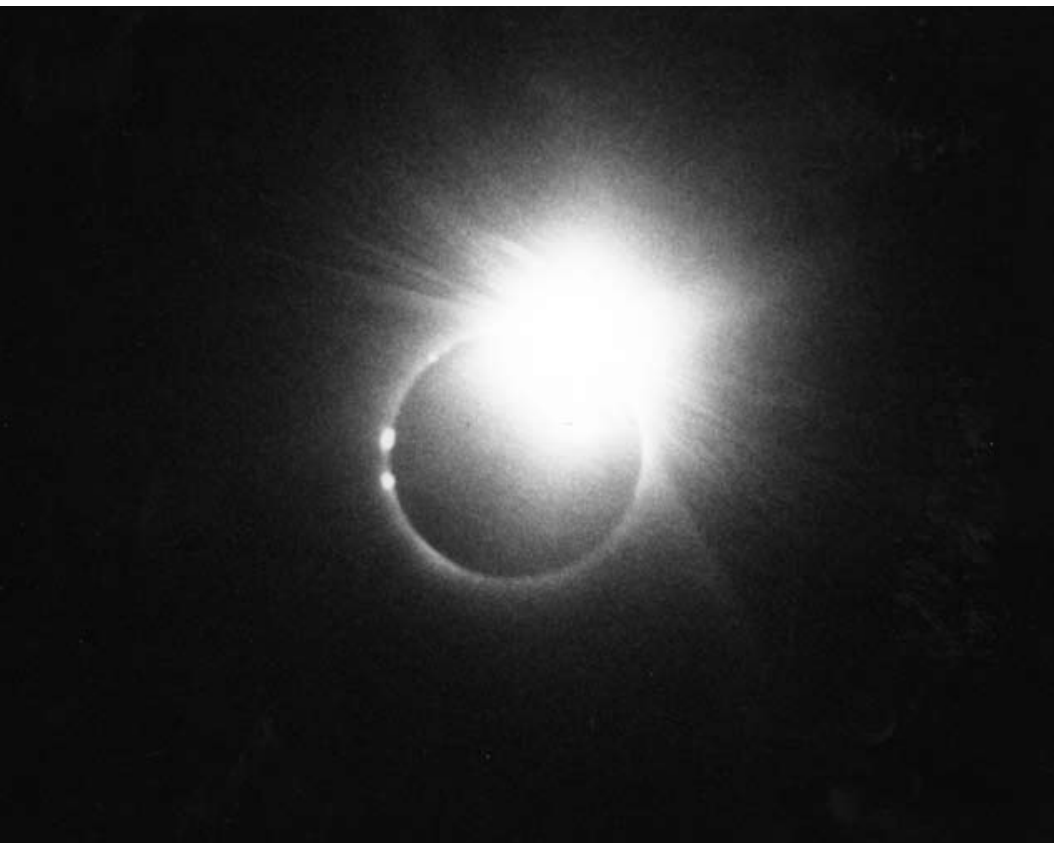

äydellisen auringonpimennyksen "timanttisormusvaihe" 22.7.1990. Kuva on otettu Itä-Suomen yllä risteilleestä lentokoneesta. (Kuva Matti Martikainen) 
linnan kohdalta. Pimennys sattui iltapäivällä, ja sää oli Keski-Suomessa erinomainen. Täydellinen vaihe kesti vain minuutin.

Suomen viimeisin täydellinen pimennys nähtiin heinäkuun 22. päivänä 1990. Pimennys sattui varhain aamulla heti auringon noustua, ja täydellisyysvyöhyke kulki Helsingistä Joensuuhun ja siitä Pohjois-Siperiaan. Sää oli lähes kaikkialla Suomessa pilvessä, mutta muutamasta kohdasta maanpinnalta ja useista lentokoneista saatiin kuvatuksi täysin pimentynyt aurinko.
Nykypäivän nuoret saavat elinaikanaan ihailla vielä toistakin näyttävää pimennystä. Kesäkuun 21. päivänä 2039 sattuu Hanko-Turku-linjalla rengasmainen auringonpimennys.

Helpommalla pääsee täydellisiä ja rengasmaisia pimennyksiä seuraamaan matkustamalla Suomen ulkopuolelle. Monet maamme tähtitieteen harrastajat ovat jo nyt käyneet kaukaisillakin paikoilla katsomassa näitä luonnon suuria näytelmiä, ja parantuvat liikenneyhteydet tuovat kaukaiset paikat yhä lähemmäs meitä.

\section{"Nokikolarin peukalo kultarahan päällä"}

aamme lounaisosissa sattui elokuun 21. päivänä 1914 täydellinen auringonpimennys. Helsingin Sanomat kertoi seuraavana päivänä pääkaupungin näkymistä.

"Kellon lähestyessä yhtä ilmestyi myymälöiden ja rappukäytävien oville sekä avattuihin akkunoihin uteliaita, silmiään siristeleviä kasvoja, jotka tähystelivät taivaalle, odottaen harvinaisen näytännön alkamista.

Alku ei näyttänyt oikein lupaavalta, sillä auringon eteen oli keräytynyt joukko pilviä. Pian ne kuitenkin alkoivat vetäytyä syrjään ja nokisten lasien läpi näkyi, miten kuu alkoi "syödä" auringon toista reunaa. Aluksi oli tuo musta paikka aivan pieni, niin että sen juuri parahiksi huomasi, mutta se suureni suurenemistaan, ikäänkuin olisi joku työntänyt hiljalleen mustaa nokikolarin peukalonpäätä säkenöivän kirkkaan kultarahan päälle.

Aurinko muuttui vähitellen sirpinmuotoiseksi kuin puolikuu. Selvästi huomasi, miten ilta pimeni ja tuntui kylmenevän.

Nuoret, yritteliäät liikemiehet, jotka viime aikoina ovat erityisesti kunnostautuneet sanomalehtien lisälehtien myyjinä, olivat tietysti varustautuneet harvinaisen luonnonilmiön varalta tuomalla markkinoille erittäin runsaan varaston pieniä, noettuja lasinpalasia. Niillä oli hintaa kokonaista 30 penniä kappale, joten niiden myynti oli paljon tulokkaampaa kuin lisälehtien kauppaaminen. Ja kun pimennys näytti edistyvän erinomaisessa järjestyksessä, niin oli kysyntä varsin vilkas.

Hetkiseksi peitti pilvi auringon. Kun se oli ilkimielisen hitaasti laahustanut auringon ohi, oli viime mainitusta näkyvissä entistä pienempi kaistale. Kello läheni kahta ja jännittävin hetki alkoi olla käsissä.

Mutta nuoret lasikauppiaat huomasivat, että kaupassa tapahtui äkillinen huononeminen.

Syy selvisi pian. Aurinkoa kohti ajautui itsepintaisen hitaasti tavattoman laaja ja paksu pilviryhmä.

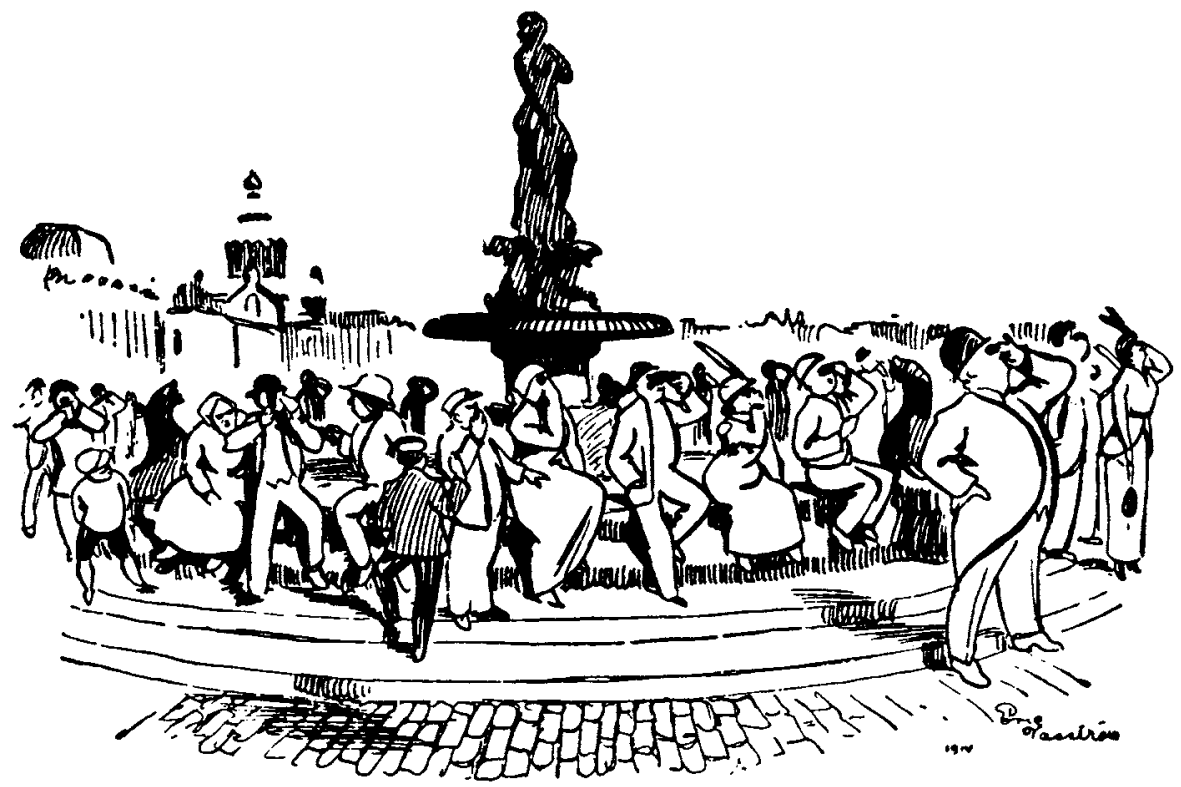

Lasipörssissä laskeutuivat kurssit huimaavaa vauhtia. Tavara, josta muutamaa minuuttia ennen oli vaadittu ja napisematta maksettu 30 penniä kappaleelta, aleni nyt niin roimasti arvossa, että pian olisi saanut 10 pennillä 3 kpl., jos vain olisi ollut ostajia silläkään hinnalla.

Paria minuuttia ennen kahta vilahti aurinko eräästä pilvenraosta, vilahti vain muutaman silmänräpäyksen ajan, mutta paljaalla silmälläkin saattoi silloin huomata, että siitä oli vain mitättömän ohut kaistale toista reunaa näkyvissä.

Sitten peitti pilvi sen kokonaan ja meillä jäi näkemättä auringonpimennys sillä hetkellä, jolloin se oli täydellinen, jolloin 35/36 auringosta oli peitossa." 


\section{Kuunpimennykset}

Kuunpimennykset ovat tavallisempia kuin auringonpimennykset. Tämä johtuu siitä, että pimennys näkyy koko sillä pallonpuoliskolla, jolla kuu on pimennyshetkellä näkyvissä, kun auringonpimennys näkyy vain pienellä alueella maapallolla.

Maapallo kuljettaa sivullaan yöpuolella varjoa, jonka keskiosaa sanotaan kokovarjoksi. Sen sisälle aurinko ei näy lainkaan. Kokovarjon ympärillä on puolivarjo, josta katsoen aurinko näkyy osittain. Puolivarjo on tummin lähellä kokovarjoa ja lähes huomaamaton ulkolaidoillaan.

Jos kuu kulkee vain maan puolivarjon läpi osumatta kokovarjoon, puhutaan puolivarjopimennyksestä. Jos kuu menee kokovarjoon, puhutaan varsinaisesta kuunpimennyksestä. Pimennys voi olla osittainen (vain osa kuusta käy kokovarjossa) tai täydellinen (kuu käy kokonaan kokovarjossa).

Puolivarjopimennyksiä on vaikea huomata. Niiden aikana kuun valo heikkenee vain hiukan. Jos kuu käy lähellä kokovarjoa, saattaa havaitsija huomata kokovarjon puoleisen osan kuusta tulevan himmeämmäksi kuin kuun vastakkaisen reunan.

Myös täydellisissä kuunpimennyksissä on syvimmällä varjossa oleva osa himmentynyt eniten ja toinen reuna vähiten.

Täydellisesti pimentynyt kuu ei ole musta, vaan kuu näkyy hyvinkin selvästi. Yliopiston tähtitorniin Helsinkiin soitettiin kesken erään pimennyksen ja kysyttiin, eikö pimennystä tapahdukaan. Allakantekijän sydän tietysti hypähti hetkeksi kurkkuun, sillä virheet almanakan ennustuksissa olisivat anteeksiantamattomia. Hetken keskustelun jälkeen kuitenkin selvisi, että soittajat pitivät pimentynyttä kuuta tavallisena täysikuuna.

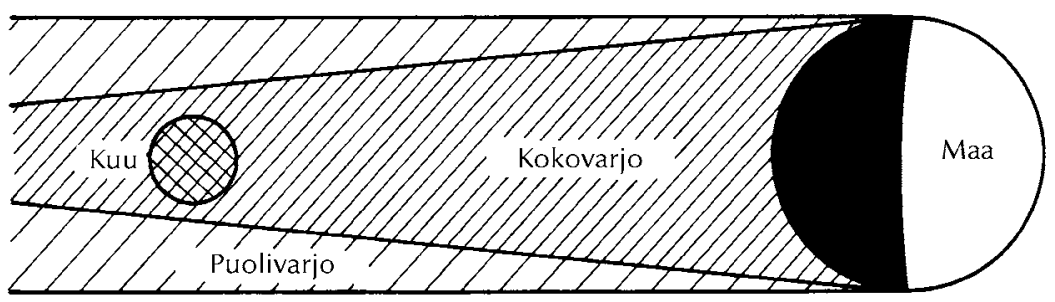

Kuunpimennyksessä kuu joutuu radallaan maan varjoon.
Jos pimentynyt kuu ja täysikuu pantaisiin vierekkäin, olisi jälkimmäinen hyvin paljon kirkkaampi. Vertailukohtaa täydellisessä pimennyksessä ei kuitenkaan ole, ja siksi erehtymisen mahdollisuus on olemassa.

Täysin pimentyneeseen kuuhun pääsee auringon valoa maapallon ilmakehän kautta. Ilmakehä muuttaa lävitseen taittuvat valonsäteet punaisiksi, ja siksi pimentynyt kuukin värjäytyy ruosteenpunaiseksi. Väri on hieman erilainen pimennyksestä toiseen ja riippuu mm. siitä, kuinka syvällä varjossa kuu käy.

Kuunpimennyksillä on mielenkiintoa lähinnä tähtitieteen harrastajille ja suurelle yleisölle, mutta myös ammattitähtitieteilijät ovat niitä tutkineet. Havaintoja on tehty mm. kuun kokonaiskirkkaudesta ja lämpötilan vaihteluista sekä varjon etenemisestä kuun pinnalla. Maan ilmakehän rakennetta on voitu tutkia kuunpimennyksistä tehdyistä havainnoista. Pimennyksen aikana on myös havaittu joskus kuun pinnalla epätavallisen kirkkaita kohtia, jotka voivat liittyä kuun sisältä tuleviin kaasupurkauksiin.

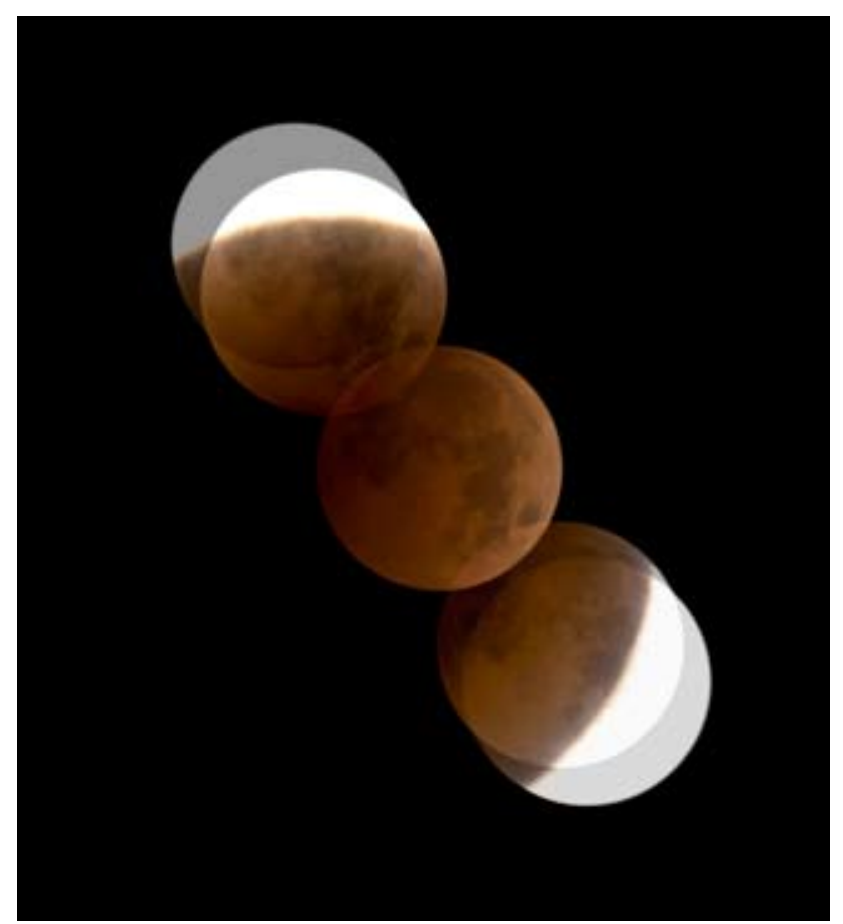

Kuun kulku maan varjon läpi tulee havainnollisesti näkyviin, kun samaan kuvaan valotetaan kuun asema pimennyksen eri vaiheissa. (Kuva Pekka Parviainen, www. polarimage.fi) 
Sivun 128 taulukkoon on merkitty huomattavimmat lähiaikoina Suomessa näkyvät kuunpimennykset.

\section{Kuun ilmiöt}

Olemme tässä luvussa käsitelleet aluksi vuosittain toistuvia ilmiöitä, jotka liittyvät vuodenaikojen vaihteluun ja maan kiertoon auringon ympäri, sekä pimennyksiä, jotka ovat harvinaisempia eivätkä ole sidottuja vuoden kiertoon.

Auringon ohella kirkkain taivaankappale on kuu, joka kiertää maapallon kerran vajaassa kuukaudessa. Almanakoissa kerrotaan useita kuuhun liittyviä ilmiöitä, jotka toistuvat kuun kierron tahdissa.

Niistä huomattavin on tietysti kuun ulkomuodon vaihtelu eli kuun vaiheet, joiden mukaan osa maapallomme asukkaista on laatinut koko ajanlaskunsa. Tästä puhuttiin jo kirjamme toisessa luvussa.

Tämän päivän kaupunkilainen ei kuuta paljon tule katselleeksi, mutta kaupungin valojen ulkopuolella täysikuut ja puolikuut näkyvät selkeällä ilmalla kaikessa komeudessaan.

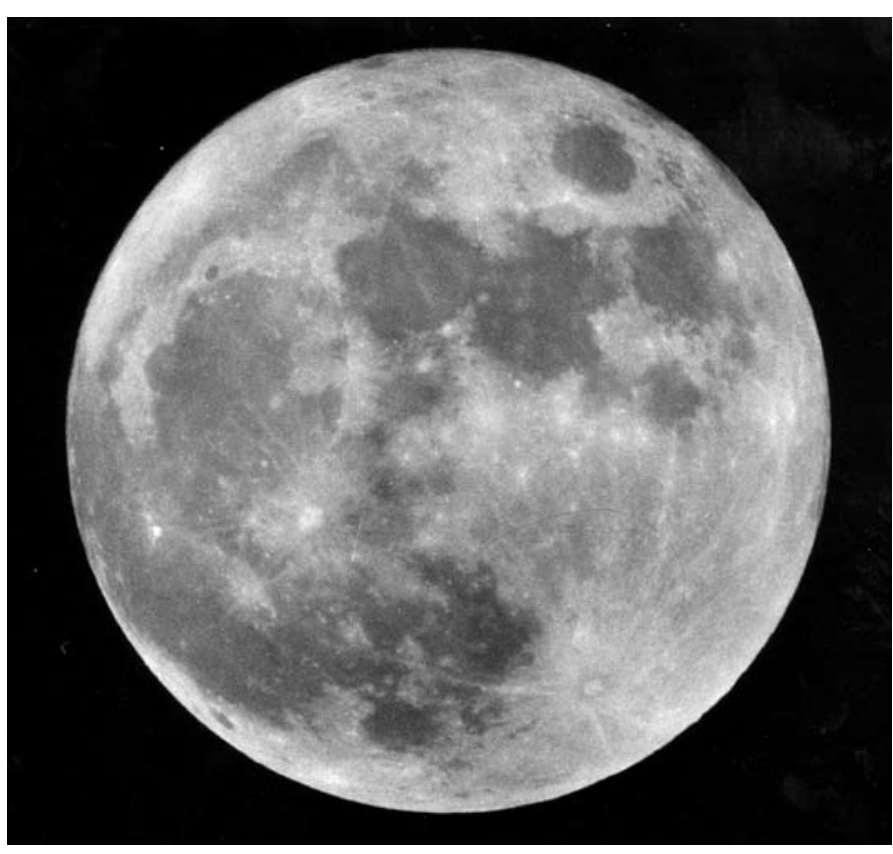

Täysikuu kuvattuna Helsingin Kaivopuistossa Ursan tähtitornin kaukoputkella. (Kuva Matti Martikainen)
Almanakka ilmoittaa uudenkuun, ensimmäisen neljänneksen, täydenkuun ja viimeisen neljänneksen ajanhetket. Uusikuu tarkoittaa hetkeä, jolloin kuu on täsmälleen samassa suunnassa kuin aurinko. Aurinko paistaa kuun takapuolelle ja maapalloon kääntynyt puolisko on kokonaan pimeänä.

Neljännekset tarkoittavat hetkiä, jolloin aurinko paistaa kuuhun suoraan sivulta ja tasan puolet kuusta on valaistuna.

Helsingin yliopiston tähtitorniin on tullut välillä kyselyjä, miksi kuusta on yleensä oikea puoli valaistuna ja vasen puoli paljon harvemmin.

Ensimmäisessä neljänneksessä oleva kuu on ihmisille paljon tutumpi näky kuin viimeisessä neljänneksessä. Syynä on se, että edellinen näkyy korkealla etelässä iltaisin, kun ihmiset vielä valvovat, jälkimmäinen taas aamuyöllä.

Täysikuu tarkoittaa sitä hetkeä, jolloin kuu on täsmälleen vastakkaisella puolella taivasta kuin aurinko. Aurinko paistaa kuuhun suoraan edestäpäin ja saa sen loistamaan hyvin kirkkaana.

Koska täysikuu on taivaalla aurinkoa vastapäätä, se nousee illalla auringon laskiessa, on korkeimmillaan etelässä keskiyöllä ja laskee aamulla auringon noustessa.

Kuun vaiheet ilmoitetaan useimmissa suomalaiskalentereissa pienillä pyöreillä symboleilla, joista uudenkuun merkki on kokonaan musta

), ensimmäisessä neljänneksessä on kuun oikea puoli valkoinen kuten taivaallakin $(\mathcal{D})$, täysikuu on avoympyrä $(\bigcirc)$ ja viimeisessä neljänneksessä on vasen puoli valkoisena $(\mathbf{O})$.

Yliopiston almanakka ja eräät muut kalenterit kertovat kuun ilmiöistä pari muutakin: kuun etäisyyden vaihtelut ja kuun korkeuden vaihtelut.

Kuun etäisyys vaihtelee kuun todellisen kiertoajan jaksossa. Kuu kiertää maapallon 27,3 vuorokaudessa, vaikka kuun vaiheiden jakso on 29,5 vuorokautta. Kuun keskimääräinen etäisyys on 385000 km, mutta pienimmillään etäisyys voi olla $353000 \mathrm{~km}$ ja suurimmillaan $405000 \mathrm{~km}$. Vaikka lähinnä ja kauimpana olo merkitäänkin kalenteriin, on etäisyyden vaihtelua vaikeata huomata mitenkään. Jos tekisi tarkkoja mittauksia kuun läpimitasta, huomaisi kuun näennäisen koon hieman kasvavan, kun kuu tulee meitä kohti, ja pienenevän, kun kuu etääntyy meistä. Kaukaisimmillaan kuu on läpimitaltaan kymmeneksen pienempi kuin lähimmillään, mutta vertauskohdan puuttuessa eroa on vaikea huomata. 
Toinen Yliopiston almanakkaan merkitty ilmiö koskee kuun aseman vaihtelua taivaalla. Ulkona liikkujat ovat varmasti havainneet, että kuu käy välillä hyvin korkealla taivaalla ja välillä taas hädin tuskin nousee etelätaivaalla hetkeksi näkyviin.

Korkeus vaihtelee suunnilleen samassa 27,3 päivän jaksossa kuin etäisyyskin. Matalimman ja korkeimman aseman väliaika on noin kaksi viikkoa.

Korkeudet vaihtelevat myös pitemmässä jaksossa, sillä kuun ratataso kiertää kertaalleen ympäri 18,6 vuodessa. Joinakin vuosina kuu käy ennätyskorkealla tai pysyttelee ennätysmatalalla. Tällöin koko Keski- ja Pohjois-Suomessa Tampereelta ylöspäin on kuukaudessa sellaisia päiviä, jolloin kuu ei nouse lainkaan, ja sellaisia päiviä, jolloin kuu on taivaanrannan yläpuolella useita vuorokausia yhtä päätä.

Yhdeksän vuotta myöhemmin kuu taas nousee ja laskee koko Suomessa hyvin säntillisesti joka päivä ja pysyttelee taivaalla keskikorkeuksilla.

\section{Mustan kuun mahtia ja täyden kuun hulluutta}

ansan parissa on kuun vaiheita seurattu almanakoista tarkkaan ja yhdistetty ne monenlaisiin asioihin. Keskiaikainen astrologia uskoi kuun sanelevan suosiolliset ja epäsuotuisat päivät (ks. viimeinen luku almanakkojen kehityksestä). Samoja uskomuksia on jäänyt elämään nykypäiviin asti.

Osa uskomuksista liittyy uudenkuun hetkiin, joista on käytetty nimiä musta kuu, kuiva kuu tai alakuu. "Syylät lähti, kun kuivana tuntina kastettiin pojan kädet tuhkaveteen; tuhkavettä oli saatu, kun äiti oli lämmittänyt ja putsannut leivinuunin. Kolmen päivän päästä syylät oli poissa", kertoo yksi soittaja.

Pajukoiden nujertamiseen taas on paras aika 7-8 päivää ennen mustaa kuuta, ja paras aika vuodesta on mätäkuu.

Kuun vaiheet on almanakassa yleensä ilmoitettu minuutin tarkkuudella. Ainoa poikkeus oli 1970-luvulla, kun almanakkauudistuksen yhteydessä numerot pyöristettiin täysiin tunteihin. Vaiheitahan ei voi minuutin tark kuudella kukaan havaita, ja siksi ajateltiin tunnin tarkkuuden riittävän.

Professori Jaakko Tuominen sai heti Helsingin yliopiston tähtitorniin vihaisen puhelinsoiton, jossa kyseltiin kuka on syyllinen tällaiseen epä-
Toki tällöinkin se tekee välillä lyhempiä ja välillä pitempiä kaaria taivaalla.

1990-luvun lopulla kuu nousi ja laski hyvin säännöllisesti, mutta alkoi jo 1999 jättää Utsjoella muutamien päivien nousut ja laskut väliin. Suurimmillaan vaihtelut olivat vuonna 2006, jolloin laajassa osassa Suomea voitiin nauttia - tai kärsiä - kuuttomista vuorokausista ja ympärivuorokautisista kuutamoista.

\section{Planeettojen kohtaamiset}

Monen almanakan aukeamilla, esimerkiksi Yliopiston almanakassa ja Suomen kansan kalenterissa, esiintyy vielä nykyäänkin salaperäisen näköisiä merkkejä, jotka kertovat planeettojen, kuun ja auringon asemista. Näitä merkkejä on käytetty esimerkiksi sään ennustamiseen, ja siksi niitä on sanottu "myrskynmerkeiksi".

tarkkuuteen. Kun soittajalta kysyttiin, mihin minuuttilukuja tarvittaisiin hän kertoi, että niillä on paljon käyttöä esimerkiksi viljan kylvössä, puiden ja pensaiden istutuksessa ja vesakoiden hävittämisessä.

Soittaja kertoi myös lapsuudestaan tapauksen, jossa erään talon seinät olivat olleet täynnä torakoita. Ne piti hävittää, eikä mitään aineita tarvittu, pelkkä lakaisu riitti, "kun homma tehtiin viimeisellä tunnilla".

Juuri siksi tarkat minuuttiluvut täytyy almanakassa ilmoittaa, että niitä ei havainnoista voi saada selville, sanoi soittaja.

Minuuttiluvut otettiin takaisin almanakkaan.

Täydenkuun vaikutusta on ajateltu vielä suuremmaksi kuin uudenkuun. Rikokset lisääntyvät, mielisairaus iskee, unettomuus vaivaa ja synnytyssairaaloihin jonotetaan täydenkuun aikaan. Jopa ihmissudet lähtevät liikkeelle kuun mollottaessa kirkkaimmillaan.

Suuri osa täysikuuhun liittyvistä uskomuksista on perättömiä. Kymmenet tutkimukset ovat todenneet, että synnytyksiä ei satu täydenkuun aikaan yhtään tavallista enempää eikä rikostilastoissa näy mitään piikkiä. Esimerkiksi suomalaispoliisi Veijo Svenn tutki vuosien 1985-1990 rikostilastoista 32 eri asiaryhmää itsemurhista ja kotihälytyksistä tappoihin ja murhapolttoihin. Kuulla ei ollut minkäänlaista vaikutusta rikosten esiintymiseen.

Sen sijaan useimpien ihmisten tuttavapiirissä on sellaisia, jotka kärsivät unettomuudesta täydenkuun paistaessa. Herkkiin ihmisiin kirkas valo tai tietoisuus täydenkuun ajasta voi aiheuttaa lieviä vaikutuksia, mutta hulluuteen asti ei täysikuu onneksi uhrejaan suista. 


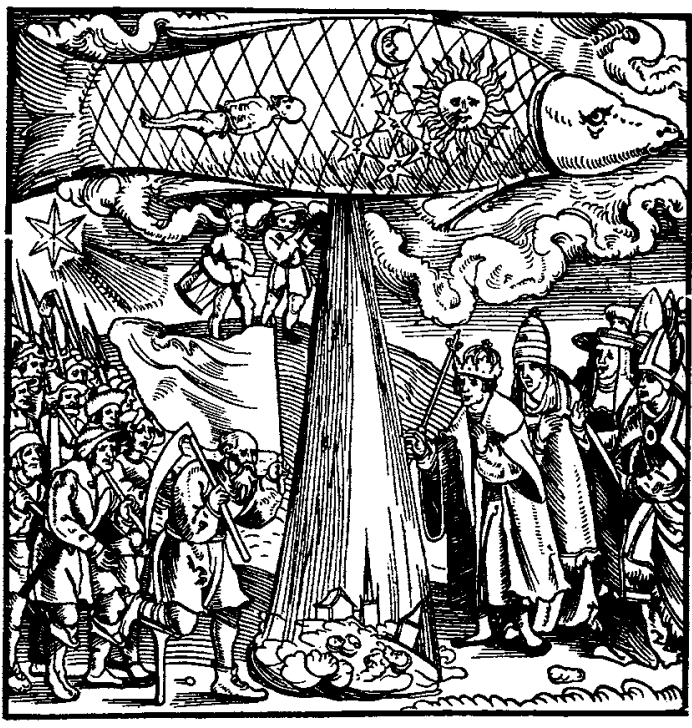

Planeettojen kohtaaminen Kalojen tähdistössä 1524 herätti suurta pelkoa Euroopassa. Piirros vuodelta 1523.

Vanha kansa tietää esimerkiksi, että "pillitähti" ( $\sigma^{\top}$ Mars) ja "tuurupää" (ఫ Merkurius) tuovat tuulta ja myrskyä, "kylmän tähti" (24 Jupiter) tuo koleaa ja "karmastuoli" ( $乞$ Saturnus) taas sadetta.

Merkit ovat aikoinaan syntyneet käytännön pakosta. Almanakan riveillä ei ole tilaa pitkille sanoille ja selityksille, ja siksi tapahtumat on täytynyt kertoa lyhenteillä.

Neljän kirkkaan planeetan merkit tulivat esille jo ylempänä, ja viides paljain silmin näkyvä planeetta on Venus ${ }_{+}$. Auringolla on oma merkkinsä $\odot$.

Jos kuun ja planeetan merkki on sijoitettu vierekkäin, se kertoo, että kuu on lähellä kyseistä planeettaa. Kahden planeetan ollessa lähekkäin planeettojen merkkien välissä on kohtaamista tarkoittava merkki $\sigma$. Sama merkki esiintyy planeetan ollessa auringon lähellä eli konjunktiossa. Venukselle ja Merkuriukselle tehdään ero alakonjunktion $(q$ al. $\sigma \odot)$ ja

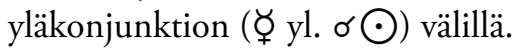

Kun Venus tai Merkurius on kauimmillaan auringon itä- tai länsipuolella, tämä ilmaistaan lyhenteillä $\bigcirc$ it. $\odot$ tai $\Varangle$ länt. $\odot$.

Kun planeetta on oppositiossa eli vastapäätä aurinkoa, on planeetan ja auringon välissä merkki $\circ^{\circ}$, esim. $24 \circ^{\circ} \odot$.

Yliopiston almanakkaan lisättiin 1970-luvulla taulukot, joissa myös myrskynmerkeille annetaan selväkielinen selitys. Almanakasta löytyvät nykyään taulukot "kuun ilmiöille", "auringon liikkeelle eläinradalla" ja "tapahtumille joissa osallisena planeetta". Niitä käyttämällä voi opetella lukemaan almanakan lyhennekieltä, jossa kerrotaan pienessä tilassa monista tähtitaivaan tapahtumista.

\section{Tähtisateet}

Olemme tässä ja edellisissä luvuissa käyneet läpi almanakan tähtitieteellistä osaa ja auringon, kuun ja planeettojen ilmiöitä. 1970-luvun almanakkauudistuksessa Yliopiston almanakkaan otettiin näiden lisäksi mukaan pieni taulukko tunnetuimmista tähtisateista.

Tähtisateet (tai tähdenlentoparvet, kuten tähtitieteen harrastajat yleensä sanovat) eivät ole yleensä kovinkaan näyttäviä "sateita". Joskus tähtisade merkitsee vain muutamaa ylimääräistä tähdenlentoa tunnissa. Mutta joskus on kyllä sattunut todellisiakin sateita, jolloin tähdenlentoja vilahtelee taivaalla vähän väliä.

Tähdenlentoja eli meteoreja ovat kaikki varmasti nähneet. Ne ovat yötaivaalla näkyviä nopeasti välähtäviä valoja, jotka vetävät taivaalle lyhyen juovan ennen sammumistaan. Niitä voi nähdä muutaman kappaleen tunnissa selkeänä yönä.

Tähdenlennon aiheuttaja on pieni pölyhiukkanen, joka tulee avaruudesta ja törmää maapallon ilmakehään. Se leimahtaa kitkan vaikutuksesta palamaan ja tuhoutuu silmänräpäyksessä.

Avaruuden hiukkanen on yleensä hiekanjyvästä pienempi. Isommat muruset aiheuttavat jo komean tähdenlennon. Kirkkaimmat tähdenlennot voivat olla näkyvissä useita sekunteja ja voittaa valossa taivaan kirkkaimmat tähdet. Tällaisia tähdenlentoja sanotaan tulipalloiksi.

Tähdenlentoina näkyvät hiukkaset ovat peräisin pääasiassa aurinkokunnan pyrstötähdistä. Pyrstötähdet hajoavat vähitellen $\mathrm{mm}$. auringon lämmön vaikutuksesta, ja niistä irtoaa pölyhiukkasia ja hiekansiruja. Hiukkaset kulkevat alkuun samalla radalla kuin pyrstötähti. Jos maapallo sattuu kulkemaan pyrstötähden radan poikki, hiukkasia osuu paljon maapallon ilmakehään, ja ne juuri aiheuttavat tähdenlentoparvet.

Koska kaikki hiukkaset ovat ennen maapalloon osumistaan samalla radalla, ne näyttävät tulevan taivaalta samasta suunnasta. Tähtisateiden aikana tähdenlentoja nähdään eri puolilla taivasta, mutta jos tähdenlen- 


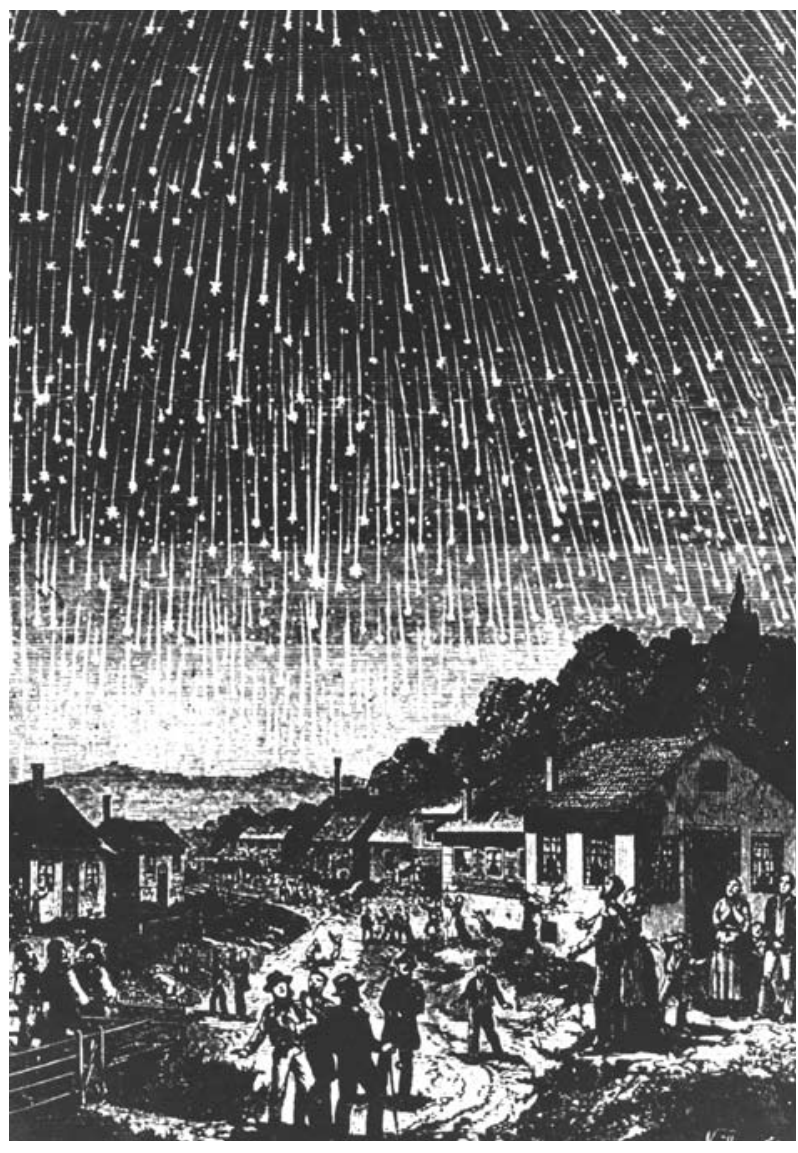

Leonidien tähdenlentoparvi aiheutti 1833 todellisen tähtimyrskyn.

tojen liikesuuntia jatketaan taaksepäin, suunnat näyttävät leikkaavan yhdessä pisteessä. Sitä sanotaan tähdenlentoparven säteilypisteeksi.

Kyseessä on sama ilmiö, joka nähdään esimerkiksi autossa, kun sillä ajetaan kovaa vauhtia lumisateen läpi. Lumihiutaleet näkyvät auton sivuilla nopeasti vilahtelevina juovina. Kaikki lumihiutaleet näyttävät tulevan samasta suunnasta, suoraan auton edestä.

Tähtisateet saavat nimensä sen mukaan, missä tähdistössä niiden säteilypiste sattuu olemaan. Almanakan tähtisadetaulukosta löytyvät mm. perseidit, jotka näyttävät tulevan Perseuksen tähdistöstä, ja leonidit, joiden säteilypiste on Leon eli Leijonan tähdistössä.

Tähtisateet ovat varsinkin tähtitieteen harrastajille kiintoisia kohteita.

\section{$\sim$ Tunnetuimpia tähdenlentoparvia}

Parvi

Maksimiaika

Kvadrantidit

Lyridit

Perseidit

Orionidit

Leonidit

Geminidit

tammikuun 3.-4.
huhtikuun 22.-23.
elokuun 12.-13.
lokakuun 21.-22.
marraskuun 17.-18.
joulukuun 13.-14.

Meteoreja tunnissa

keskimäärin

60

$10-20$

70-110

10

$10-20$

Päivämäärä saattaa poiketa ilmoitetusta kahdellakin päivällä ja tähdenlentoparvi saattaa kestää useita päiviä. Näiden lisäksi tunnetaan lukuisia vähäisempiä parvia.

Harrastajat saattavat makailla elokuun öinä tuntikausia ulkosalla ilmapatjoillaan laskemassa kohdalle osuvien perseidien määrää. Tavallisten ihmisten on vaikeampi havaita tähtisadeöinä mitään erikoista taivaalla.

Näyttäviäkin tähtisateita on ollut, kuten jo todettiin. Erikoisesti on kunnostautunut leonidien parvi. Maapallo kulkee 33 vuoden välein parven tiheimmän osan läpi, ja tällöin voi näkyä todellinen tähtimyrsky. Leonidit myrskysivät esimerkiksi 1966, jolloin Yhdysvaltojen eräissä osissa näkivät hämmästyneet ihmiset jopa tuhat tähdenlentoa minuutissa. Leonidien uusin huippu sattui vuosille 1998 ja 1999. Vuoden 1998 marraskuussa nähtiin Suomessa vain hieman tavallista suurempi määrä meteoreja, mutta Kaukoidässä tähtisade oli runsaampi. Varsinaiseksi myrskyksi se ei kuitenkaan riittänyt. 


\section{KIRKKOVUODEN JUHLAT}

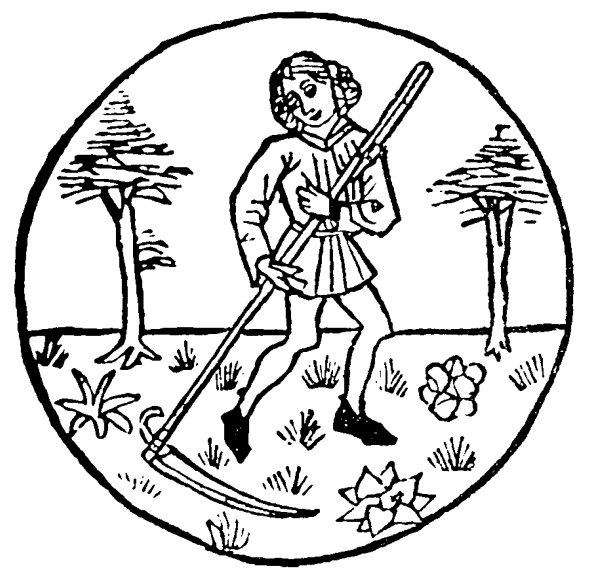

Heinäkuun askareita Johannes von Gmundenin kalenterissa: Leikataan viljaa.

\section{$\mathrm{T}$}

$\checkmark$ ammikuun 1. päivä on länsimaisen kalenterin uudenvuodenpäivä, jonka paikan Julius Caesar vahvisti yli 2000 vuotta sitten, nelisenkymmentä vuotta ennen Kristuksen syntymää. Rooman vallan murruttua Euroopassa 300- ja 400-luvulla ei keisarin käskyä haluttu suinkaan kaikkialla noudattaa. Kristillisen kirkon vaikutusvalta oli kasvanut vähitellen hyvin suureksi, ja kirkko halusi pitää vuoden taitekohtana jotakin uskontonsa kannalta merkittävää päivämäärää, ei maallisen keisarin määräämää.

Useissa maissa vuosi aloitettiin Marian ilmestyspäivästä (25.3.), esimerkiksi Englannissa 1700-luvulle asti, tai joulusta. Ruotsi-Suomessa kirkkopäivien tekstit aloitettiin ensimmäisestä adventtipäivästä, kuten vielä tänäkin päivänä tehdään. Silti kalenterivuoden alku on jo ensimmäisissä Ruotsin ja Suomen messukirjoissa 1300- ja 1400-luvulla merkitty tammikuun 1. päivän kohdalle.

Vielä eri kohdassa oli maallinen tilivuosi. Maaseudulla palkollisten tilivuosi päättyi syksyllä satokauden päätyttyä, aluksi mikkelinpäivän tienoilla, sittemmin loka-marraskuun vaihteessa, kekrinä.

Vuodenvaihteen määritelmä haluttiin meilläkin yhdenmukaistaa, ja siksi vuonna 1559 myös tilikauden alku määrättiin tammikuun alkuun. Kun ensimmäiset kalenterimme ilmestyivät 1600-luvun alussa, niissä vuosi alkoi nykyiseen tapaan tammikuulla. Monissa muissa Euroopan maissa muutos tehtiin myös 1500-luvulla, mutta esimerkiksi Venäjällä vasta 1725 ja Englannissa 1753. 


\section{Kirkkovuosi: adventista adventtiin}

Kirkkovuosi alkaa edelleenkin eri kohdasta kuin tavallinen kalenterivuosi. Kirkon vuosi aloitetaan perinteisesti adventista, joka on marrasja joulukuun vaihteessa, ja päätetään tuomiosunnuntaihin marraskuun lopulla.

Vuonna 1993 vahvistetussa kirkkolaissa on luettelo kirkollisista juhlapäivistä. Lain mukaan "kirkollisia juhlapäiviä ovat joulupäivä, toinen joulupäivä, uudenvuodenpäivä, loppiainen, pitkäperjantai, pääsiäispäivä, toinen pääsiäispäivä, helatorstai, helluntai, juhannuspäivä ja pyhäinpäivä".

Kirkkovuoden suurimmat pyhät ovat joulu ja pääsiäinen, joiden ympärille ovat rakentuneet pitkät juhla-ajat. Joulu alkaa ensimmäisestä adventtisunnuntaista ja jatkuu loppiaiseen asti. Pääiäisaika on vielä pitempi, laskiaisesta helatorstaihin.

Suomessa on lisäksi kaksi ei-kirkollista juhlapäivää, joita kirkkolaki ei mainitse: itsenäisyyspäivä ja vappu. Puhumme niistä tuonnempana.

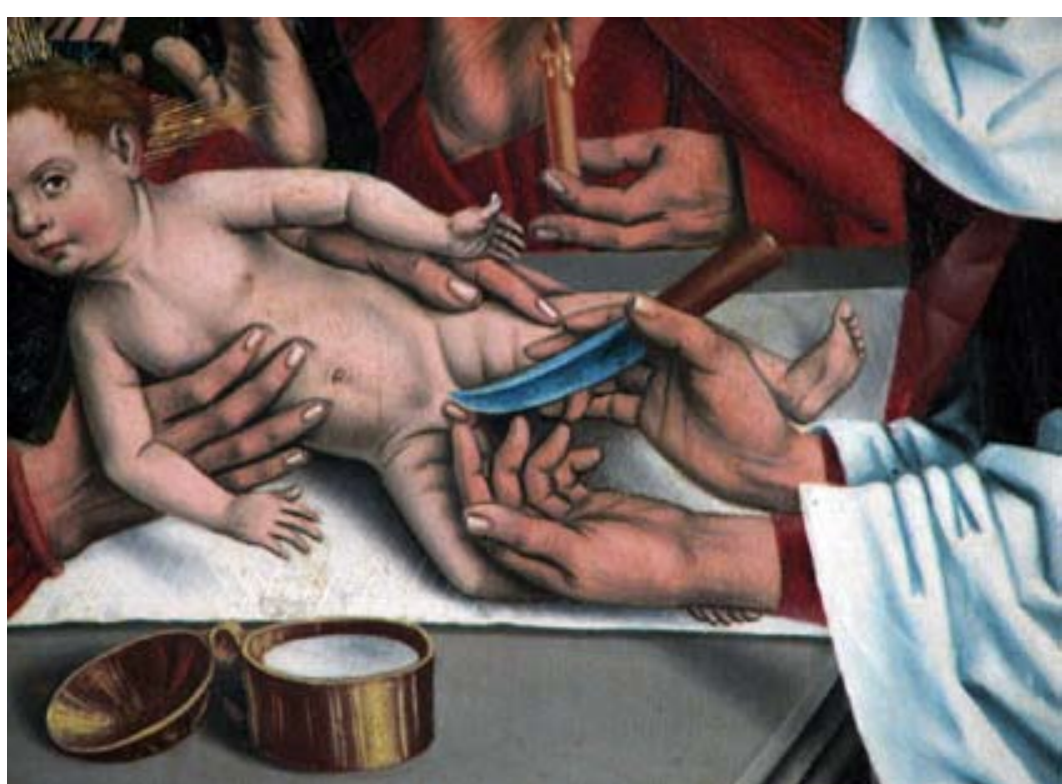

Jeesuksen ympärileikkaus. Friedrich Herlinin maalaus vuodelta 1466. (Kuva Daniel Leclercq, Wikipedia)
Kaikki kirkon suurimmat juhlat keskittyvät kirkkovuoden ensimmäiseen puoliskoon, joulu-toukokuuhun (tai kesäkuuhun jos helluntai on kesäkuun puolella). Toinen puolisko eli kesä ja syksy on lähes juhlatonta aikaa.

Vaikka kirkkovuosi alkaa adventista, käymme tässä kirkon juhlapäivät läpi normaalikalenterin mukaan vuoden alusta eli uudenvuodenpäivästä lähtien.

\section{Uusivuosi ja loppiainen}

Uuden vuoden vastaanotto oli kaksituhatta vuotta sitten roomalaisilla aivan yhtä hilpeä juhla kuin nykyajan ihmisillä. Kirkko halusi keskiajalla antaa uudenvuodenpäivälle myös uskonnollista sisältöä, ja aiheeksi valittiin Jeesuksen ympärileikkaus. Tuohon aikaan, kuten vieläkin Lähi-idässä, poikalapsilta nipsaistiin pippelistä esinahka pois jo vauvaiässä.

Koska Kristuksen esinahan (tai -nahattomuuden) juhliminen tuntuu nykyihmisistä hieman vieraalta, korostetaan kirkon piirissä ympärileikkaukseen liittyvää nimenantoa. Meillä uudenvuoden tekstit puhuvat Jeesus-nimestä. Uuttavuotta voi siten pitää Jeesuksen nimipäivänä, vaikka

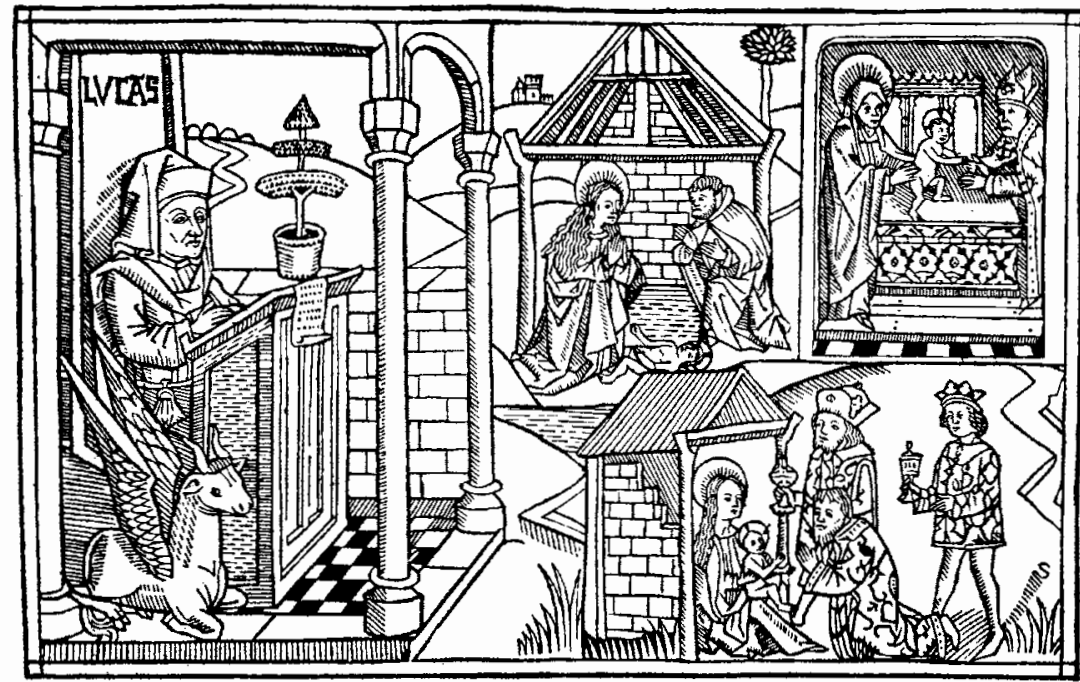

Evankelista Luukas ja kolme kuvaa Jeesuksen lapsuudesta: syntymä, temppeliin tuonti ja kolmen tietäjän käynti. Kuva saksalaisesta Raamatusta 1400-luvun lopulta. 
päivälle ei meidän kalentereissamme olekaan merkitty mitään nimeä.

Katolinen kirkko on luopunut uudenvuoden ympärileikkaus-selityksestä ja juhlii tammikuun 1. päivää Jeesuksen äidin Marian juhlapäivänä, yhtenä vuoden monista Maria-päivistä.

Loppiainen 6. tammikuuta on vanhastaan ollut joulunajan viimeinen juhlapäivä. Suomalaisen nimensä se on saanut joulunpyhien loppumisesta. Muissa kielissä nimi viittaa esimerkiksi itämaan tietäjiin ("kolmen kuninkaan päivä") tai Kaanaan häihin, joissa Jeesus ensimmäisen kerran näytti kirkkautensa ("Kristuksen ilmestymispyhä" eli epifania).

Suomen kirkoissa puhutaan loppiaisena kolmen tietäjän käynnistä Jeesuksen luona. Loppiaista pidetään meillä myös lähetystyön juhlana. Ortodoksisessa kirkossa loppiainen on Jeesuksen kasteen juhla.

Loppiainen on nykyään perinteisellä kiinteällä paikallaan tammikuun kuudentena, mutta 1973-1991 se oli viikonloppuun sidottu pyhä, jota vietettiin tammikuun 6. ja 12. päivän välisenä lauantaina. Puhumme liikkuvien pyhien siirrosta enemmän tämän luvun lopulla.

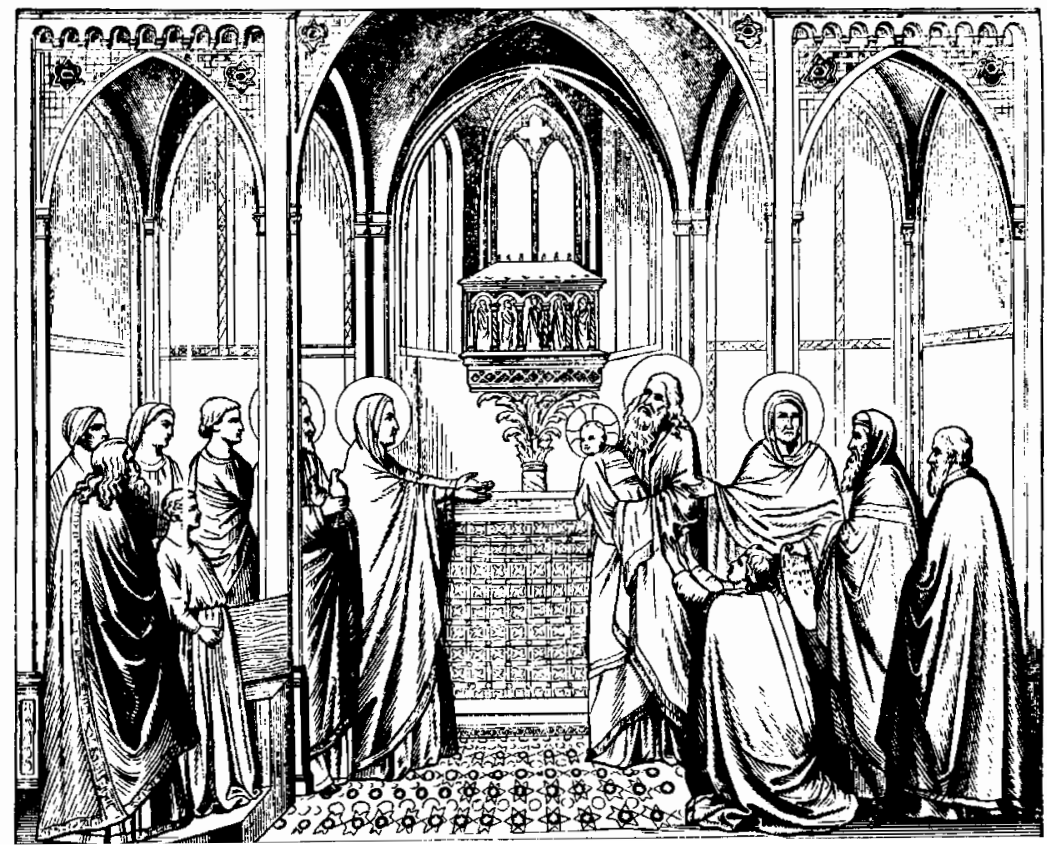

Jeesus tuotiin temppeliin 40 päivän ikäisenä. Muistopäivän nimenä on nykyään kynttilänpäivä. Piirros on tehty assisilaisessa kirkossa olevan maalauksen mukaan.

\section{Kynttilänpäivästä laskiaiseen}

Kynttilänpäiväksi sanotaan helmikuun alun sunnuntaita. Sitä vietettiin alkuaan Marian puhdistuspäivänä. Jeesuksen aikaan äitiä pidettiin 40 päivää synnytyksestä "epäpuhtaana" eikä hän saanut esimerkiksi käydä temppelissä. Mutta 40 päivää joulun jälkeen eli helmikuun 2. päivänä Maria meni temppeliin Mooseksen lain mukaisesti uhraamaan kaksi kyyhkystä ja sai näin puhtautensa takaisin.

Nykyisen nimensä kynttilänpäivä on saanut katolisen kirkon tavasta vihkiä koko vuoden kynttilät tänä päivänä.

Kynttilänpäivän vanha paikka oli 2. helmikuuta, mutta 1772 se siirrettiin välillä 2.2.-8.2. olevaan sunnuntaihin. Jos kuitenkin 2.2. sattuu laskiaissunnuntaihin tai sen alusviikkoon, juhlaa vietetään jo edellisenä sunnuntaina. Jos laskiaissunnuntai on aikaisimpana mahdollisena päivänään 1.2. (kuten tapahtuu seuraavan kerran vuonna 2285), on kynttilänpäivä 8.2.

Kynttilänpäivän tienoille sattuu yleensä kaksi pyhäpäivää, joille käytettiin vuoteen 2000 asti latinalaisia nimiä septuageesima- ja seksageesimasunnuntai. Nämä ovat pääsiäsjakson ensimmäiset pyhät, ja niiden paikka lasketaan pääsiäisestä. Nimet olivat peräisin latinankielisistä lukusanoista 70 ja 60. Septuageesimasunnuntaina alkoi 70-päiväinen "luopumisen aika", joka päättyi pääsiäistä seuraavana lauantaina, ja seksageesimasunnuntaina taas 60-päiväinen "leskeyden aika", joka päättyi pääsiäispäivää seuraavana keskiviikkona.

Oudot nimet herättivät kansan keskuudessa ihmettelyä. Esimerkiksi yksi iloinen naisääni kysyi yliopiston almanakkatoimistosta seksageesiman alkuperää, ja kysyjä tuntui hieman pettyneeltä kun nimellä ei ollutkaan mitään tekemistä seksin kanssa.

Latinalaiset nimet siirtyivät 2000-luvun alussa historiaan, kun kirkko uusi useiden pyhäpäivien nimet (ks. seuraavan aukeaman laatikko). Septuageesimasunnuntaista tuli aivan suomalaisittain kolmas sunnuntai ennen paastonaikaa ja seksageesimasunnuntaista toinen sunnuntai ennen paastonaikaa.

\section{Paastonaika alkaa}

Laskiaista edeltävää aikaa sanotaan esipaastoksi. Varsinainen paastonaika 
eli valmistautuminen pääsiäiseen käsittää neljäkymmentä päivää ennen pääsiäistä; tällöin sunnuntaita ei lasketa paastopäiviksi. Paastonaika alkaa tarkkaan ottaen laskiaistiistain jälkeisenä yönä ja päättyy pääsiäispäivää edeltävänä yönä.

Laskiaissunnuntaiksi sanotaan paastonaikaa edeltävää sunnuntaita, joka on siis seitsemän viikkoa ennen pääsiäistä. Se voi olla aikaisintaan 1. helmikuuta ja myöhäisintään 7. maaliskuuta.

Nimensä laskiainen on saanut sanasta laskea: nykyään arvellaan, että kyse on siitä, että paasto lasketaan (=päästetään) alkamaan, tai siitä, että paastopäivien laskeminen aloitetaan.

\section{Pyhäpäivien vanhat ja uudet nimet}

Kirkko uudisti vuosituhannen vaihteessa pyhäpäivien nimet. Lopullisen Lhyväksymisen uusille nimille antoi kirkolliskokous toukokuussa 1999. Muutos astui voimaan adventtina vuonna 2000. Tärkeimpien pyhien nimet pysyivät ennallaan, muutamissa muissa nimissä muuttui vain hieman sanamuoto, mutta joidenkin pyhien nimet uusittiin kokonaan. Alla on lista vuoden pyhäpäivistä vanhan ja uuden evankeliumikirjan mukaan.

\section{Vanha nimi}

Uudenvuodenpäivä

Uudenvuodenpäivän jälkeinen sunnuntai

Loppiainen

X. loppiaisen jälkeinen sunnuntai $\quad X$. sunnuntai loppiaisesta $-$

Kynttilänpäivä

Septuagesimasunnuntai

Seksagesimasunnuntai

Laskiaissunnuntai

X. paastonajan sunnuntai

Marianpäivä

Palmusunnuntai

Pitkäperjantai

Pääsiäispäivä

2. pääsiäispäivä

1. pääsiäisen jälkeinen sunnuntai

2. pääsiäisen jälkeinen sunnuntai

\section{Nykyinen nimi}

Ennallaan

2. sunnuntai joulusta

Ennallaan

Pyhän Henrikin muistopäivä

Ennallaan

3. sunnuntai ennen paastonaikaa

2. sunnuntai ennen paastonaikaa

Ennallaan

Ennallaan

Marian ilmestyspäivä

Ennallaan

Ennallaan

Ennallaan

Ennallaan

1. sunnuntai pääsiäisestä

2. sunnuntai pääsiäisestä jne.
Vaikka meillä ei paastonajalla ole enää samaa merkitystä kuin katolisissa maissa, laskiaisena on vieläkin tapana syödä tukevasti. Nautimme vaikkapa hernerokkaa ja laskiaispullaa, ettei sitten paastonaikana pääse tulemaan nälkä.

Katolisissa maissa laskiaiseen liittyvät iloiset karnevaalit. Esimerkiksi Rio de Janeirossa juhlitaan joka vuosi laskiaissunnuntaista laskiaistiistaihin. Sana karnevaali on tullut latinan sanoista carne vale, hyvästi liha: paaston alettua ei lihaa saanut syödä ennen kuin pääsiäisenä. Katolinen kirkko on nykyään huomattavasti keventänyt paastonajan lihansyöntikieltoa, mutta karnevaalit ovat säilyneet yhtä riehakkaina juhlina.

\begin{tabular}{|ll|}
\hline Rukoussunnuntai & 5. sunnuntai pääsiäisestä \\
Helatorstai & Ennallaan \\
Helluntaipäivä & Ennallaan \\
Kolminaisuudenpäivä & Pyhän Kolminaisuuden päivä \\
1. kolminaisuudenpäivän & 2. sunnuntai helluntaista \\
jälkeinen sunnuntai & \\
2. kolmin. jälkeinen sunnuntai & 3. sunnuntai helluntaista jne \\
Juhannuspäivä & Ennallaan \\
5. kolmin. jälkeinen sunnuntai & Apostolien päivä \\
Kirkastussunnuntai & Ennallaan \\
Mikkelinpäivä & Ennallaan \\
21. kolmin. jälkeinen sunnuntai & Uskonpuhdistuksen muistopäivä \\
- & Luomakunnan sunnuntai \\
- & Perheen sunnuntai \\
Pyhäinpäivä & Ennallaan \\
Kirkkovuoden lähinnä & Valvomisen sunnuntai \\
viimeinen sunnuntai & \\
Tuomiosunnuntai & Ennallaan \\
X. adventtisunnuntai & Ennallaan \\
Joulupäivä & Ennallaan \\
2. joulupäivä & Tapaninpäivä \\
- & Apostoli Johanneksen päivä \\
- & (3. joulupäivä)* \\
Joulun jälkeinen sunnuntai & Viattomien lasten päivä \\
& (4. joulupäivä)* \\
*Huom. 3. tai 4. joulupäivää vietetään pyhänä vain milloin se sattuu sun- \\
nuntaihin. & \\
& \\
&
\end{tabular}




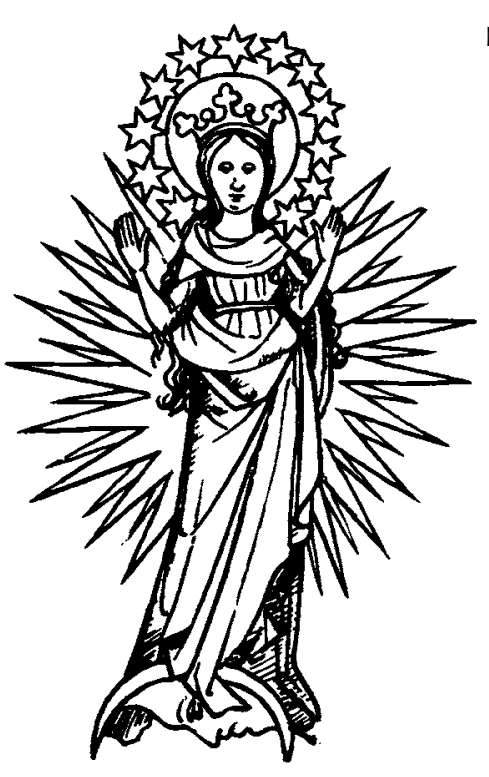

Neitsyt Maria. Piirros 1400-luvulta.

Paaston ensimmäisellä päivällä on oma nimensä, tuhkakeskiviikko. Nimi tulee siitä, että kristityt osoittivat aikoinaan katumusta ripottelemalla tuhkaa päälleen. Paastonaika on varsinkin katolisessa kirkossa katumuksen ja ripittäytymisen aikaa.

\section{Marianpäivä}

Marian ilmestyspäivää vietetään maaliskuun 22. ja 28. päivän välisenä sunnuntaina, tai jos tämä sunnuntai on palmusunnuntai tai pääsiäispäivä, palmusunnuntaita edeltävänä sunnuntaina. Siksi Marianpäivä voi olla aikaisimmillaan jopa maaliskuun 8 . päivänä. Tällä vuosisadalla aikaisin Marianpäivän päivämäärä on 9.3., joka sattui vuonna 2008.

Vuoteen 1954 asti marianpäivä oli kiinteällä paikalla 25.3. Tähän oli kuitenkin muutamia poikkeuksia. Jos 25.3. oli pääsiäispäivä tai pääsiäismaanantai, Marianpäivä oli pääsiäismaanantaita seuraavana tiistaina. Jos 25.3. sattui pääsiäisen alusviikolle (palmusunnuntain ja pääsiäislauantain välille), oli Marianpäivä palmusunnuntaita edeltävänä lauantaina.

Sisältönsä Marian ilmestyspäivä on saanut enkeli Gabrielin käynnistä neitsyt Marian luona. Enkeli ilmoitti Marialle että hänestä tulee Herran äiti. Tasan 9 kuukautta myöhemmin onkin joulu, Jeesuksen syntymäpäivä.

Täten marianpäivä ei ole pääsiäiseen liittyvä juhla, vaikka se yleensä sattuukin pääsiäisen alle paastonaikaan, vaan jouluun liittyvä erillisjuhla.

\section{Palmusunnuntai ja hiljainen viikko}

Viimeinen sunnuntai ennen pääsiäistä on nimeltään palmusunnuntai. Se on omistettu Jeesuksen tulolle Jerusalemiin, jolloin kansa levitti tielle palmunoksia.

Suomessa palmusunnuntaina on käytetty palmunlehvien sijasta pajunoksia. Ortodoksisissa kirkonmenoissa pajunoksat siunataan ja jaetaan läsnäolijoille. Kansan keskuudessa on taas ollut tapana pajunvitsoilla "virpominen". Viime aikoina varsinkin pikkutytöt ovat usein kierrelleet noidiksi pukeutuneina talosta taloon lausumassa virpomisloruja, josta palkkana on pikku makeisia.

Kaupungin porraskäytävissä virpojia näkee harvoin. Tämän kirjoittajan kohdalle on sattunut viime vuosina vain yksi kaupunkilaisvirpoja: ovikelloa soitti nuori tummaihoinen somalialaistyttö, joka suomea somasti murtaen kertoi tulleensa virpomaan. Hän sai suklaamunan palkakseen.

Pääsiäistä edeltävän piinaviikon tai hiljaisen viikon päivillä on kullakin ollut oma nimensä. Harvoin nykyään enää käytetään sellaisia nimiä kuin malkamaanantai, tikkutiistai, kellokeskiviikko tai lankalauantai. Sen sijaan yleisessä käytössä ovat edelleen kiirastorstai ja pitkäperjantai.

Kiirastorstai on ollut pitkän paaston jälkeinen puhdistuspäivä. Sen nimi tulee ruotsin sanasta skär, puhdas. Esimerkiksi ortodoksisessa kirkossa piispat pesevät kiirastorstaina alaistensa pappien jalat.

Kiirastorstai on meillä ennen kaikkea ehtoollisen asettamisen muistojuhla. Suomalaisissa kirkoissa pidetään kiirastorstai-iltana ehtoollisjumalanpalvelus, ja monet käyvät ehtoollisella tämän ainoan kerran vuodessa. Kirkoissa käy kiirastorstaisin enemmän väkeä kuin pitkäperjantaina tai pääsiäispäivänä.

Pitkäperjantaita vietetään Jeesuksen ristiinnaulitsemisen ja kärsimyskuoleman muistoksi. Pitkäperjantai on ollut Suomessa harras ja hiljainen juhla, jolloin ei ole sopinut nauraa, leikkiä tai käydä vieraisilla. 


\section{Pääsiäisjuhla}

Pääsiäispäivää vietetään ilon päivänä Jeesuksen ylösnousemuksen muistoksi. Uskontunnustuksemme sanoo, että Jeesus nousi "kolmantena päivänä" kuolleista. Tällöin käytetään vanhaa roomalaista laskutapaa, jossa sekä alku- että loppupäivä lasketaan mukaan lukuun. Perjantai on ensimmäinen, lauantai toinen ja sunnuntai kolmas päivä. Jeesuksen uskotaan nousseen haudastaan varhain sunnuntaiaamuna.

Katolisessa ja ortodoksisessa kirkossa pääsiäisyön eli lauantain ja sunnuntain välisen yön jumalanpalvelus on vuoden huomattavin tapahtuma, joka vetää kirkot täyteen väkeä ja vastaa lähinnä meikäläistä jouluaamun kirkkoa.

Juutalaisten pääsiäinen oli alkuaan (ja on vieläkin) kahdeksanpäiväinen juhla. Ruotsi-Suomessa pääsiäinen oli vielä 1700 -luvulla nelipäiväinen juhla (sunnuntaista keskiviikkoon). Vuonna 1772 se lyhennettiin kaksipäiväiseksi, ja sellainen se on edelleenkin.

Pääsiäismaanantaina kirkoissa puhutaan ylösnousseen Jeesuksen ilmestymisestä opetuslapsilleen. Nykyisessä evankeliumikirjassa annetaan raamatuntekstit kaikille perinteisen pääsiäisen kahdeksalle päivälle.

\section{Pääsiäisen paikka}

Pääsiäisen paikka määräytyy hyvin mutkikkaista tekijöistä, ja siksi sen laskemista on syytä tarkastella vähän yksityiskohtaisemmin.

Pääsiäisen paikasta on kiistelty pian kaksituhatta vuotta. Juutalaisen perinteen mukaan juhlaa haluttiin viettää kevään alkajaiseksi ja täydenkuun tienoilla. Suunnilleen yhtenäiseen käytäntöön kristityissä maissa päästiin 500-luvun jälkeen, kun Dionysius Exiguus laati entistä tarkemman pääsiäissäännön. Myöhemmin 1500-luvulla sääntöä vielä tarkennettiin samalla kun siirryttiin juliaanisesta kalenterista nykyiseen gregoriaaniseen.

Karkea sääntö on, että pääsiäinen on "kevättasauspäivää seuraavan täydenkuun jälkeisenä sunnuntaina". Tämä sääntö ei kuitenkaan ole tarkka. Ensinnäkään kevättasauspäivä ei tarkoita samaa päivää, jonka kohdalle almanakassa tasaus on merkitty, vaan se on kiinteästi maaliskuun 21. päivä. Toiseksi myöskään täysikuu ei ole se tähtitieteellinen täysikuu, jonka almanakka kertoo, vaan eräs kuviteltu tasaisesti kulkeva kuu (jonka vaiheet tosin sattuvat lähelle todellisen kuun vaiheita).

\section{Paljastaako kuunpimennys pääsiäisen päivän?}

oka joulu pohditaan Betlehemin tähden arvoitusta. Oliko se todellinen tähtitaivaan tapahtuma vai kaunis taru? (Ks. laatikko tämän luvun lopussa.)

Tähtitiedettä on käytetty avuksi myös Jeesuksen ristiinnaulitsemispäivän määräämiseen. Jeesuksen tarkkaa kuolinpäivää ei Raamatun perusteella voida selvittää. Sen tiedetään olleen Pontius Pilatuksen aikana eli vuosien 26-36 välillä, perjantaipäivänä ja juuri ennen pääsiäisjuhlaa, kuten Johanneksen evankeliumissa sanotaan.

Juutalaisten pääsiäinen tai sen aatto sattui perjantaiksi vuosina 27, 30, 33 ja 34. Todennäköisimmät päivät ovat 7. huhtikuuta vuonna 30 tai 3. huhtikuuta vuonna 33. Mutta kumpi näistä ajoista on se oikea?

Englantilaistutkijat C.J. Humphreys ja W.G. Waddington ovat ottaneet tähtitieteen avuksi. Raamatussa on mainittu, että Jeesuksen kuoleman aikaan "aurinko muuttuu pimeydeksi ja kuu vereksi". Auringonpimennystä ei kyseisenä aikavälinä Jerusalemissa satu, ja Raamatussa mainittu pimeys on tulkittu esimerkiksi voimakkaaksi hiekkamyrskyksi.

Sen sijaan kuun muuttuminen vereksi on tuttu näky kuunpimennysten aikaan. Ilmiö johtuu siitä, että kuun pinnalle osuva valo kulkee maan ilmakehän läpi, jolloin se punertuu. Yksi kuunpimennys sattui Jerusalemissa perjantaina huhtikuun 3. päivänä vuonna 33, jolloin kuu nousi illalla jo osittain pimentyneenä ja varmasti vaikuttavan näköisenä.

Englantilaistutkijat päättelevät siten alkuperäisen pitkäperjantain päivämääräksi 3.4.33.

Suomalainen asiantuntija Risto Heikkilä on tullut siihen tulokseen, että todennäköisempi päivämäärä on 7. huhtikuuta vuonna 30 ja että Raamatun mainitsemat ilmiöt ovat mahdollisesti hiekkamyrskyn aiheuttamia.

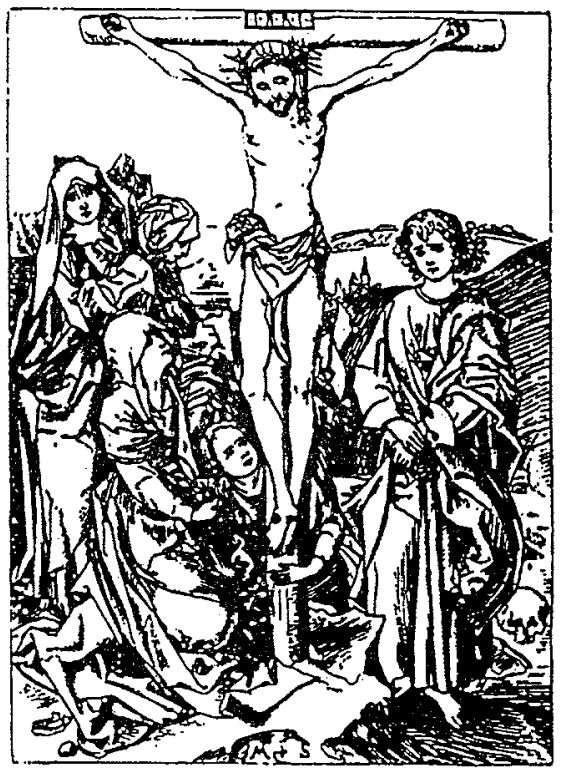




\section{Pääsiäisen päivämäärä Gaussin kaavalla}

Anettu vuosiluku jaetaan 19:Ilä ja merkitään jakojäännöstä a:Ila; jaetaan vuosiluku 4:Ilä ja saadaan jakojäännös b; jaetaan vuosiluku 7:Ilä ja saadaan jakojäännös c. Muodostetaan summa $24+19 a$, jaetaan se 30:Ilä ja merkitään jakojäännös d:Ilä. Muodostetaan toinen summa $5+2 b+4 c+$ $6 \mathrm{~d}$, jaetaan 7:Ilä ja saadaan jakojäännös e. Silloin pääsiäissunnuntain päivämäärä on joko $(22+d+e): s$ maaliskuuta tai $(d+e-9)$ :s huhtikuuta. Jos saatu päivä on 26.4., on pääsiäinen 19.4. Jos saatu päivä on 25.4. ja samalla d $=28$ ja a suurempi kuin 10, on pääsiäinen 18.4. - Muina vuosisatoina kaksi kaavassa olevaa lukua saa hieman eri arvon.

Lasketaanpa esimerkiksi pääsiäisen paikka vuonna 2013:

Vuosi jaetaan luvulla

jakojäännös

2013

$\begin{array}{cc}19 & \mathrm{a}=18 \\ 4 & \mathrm{~b}=1 \\ 7 & \mathrm{c}=4\end{array}$

$24+19 a=366$; jaetaan 30:Ilä, jakojäännös $d=6$

$5+2 b+4 c+6 d=59$; jaetaan 7:Ilä, jakojäännös e $=3$

Pääsiäisen päivämäärä on $(22+d+e): s$ maaliskuuta eli 31.3.

Niinpä karkeasta säännöstä on poikkeuksia. Yksi tällainen oli vuonna 1943. Voimme almanakasta lukea, että kevätpäiväntasaus oli maaliskuun 21. päivänä klo 14 ja täysikuu sattui seuraavana yönä klo 0.08. Pääsiäistä ei kuitenkaan vietetty seuraavana sunnuntaina, vaan vasta huhtikuun lopulla, 25.4.

Tarkan säännön mukaan laskien pääsiäinen sattuu aina maaliskuun 22. ja huhtikuun 25. päivän väliseksi ajaksi. Helpoin tapa sen paikan laskemiseksi on matemaatikko Gaussin 1800-luvun alussa julkaisema sääntö. Sen mukaan esimerkiksi vuosina 1900-2099 pääsiäisen paikka lasketaan ohessa annetun kaavan mukaan.

Ennen Gaussin keksimää sääntöä joutuivat kirkonmiehet käyttämään vielä mutkikkaampia laskutapoja. Eipä siksi ihme, että koko ajanlaskumme ajan on tehty ehdotuksia pääsiäisen paikan määräämisestä yksinkertaisemmin. Yksi järkevä mahdollisuus olisi, että se olisi jonakin tiettynä sunnuntaina maalis-huhtikuun vaihteessa. Mm. kirkkojen maailman-

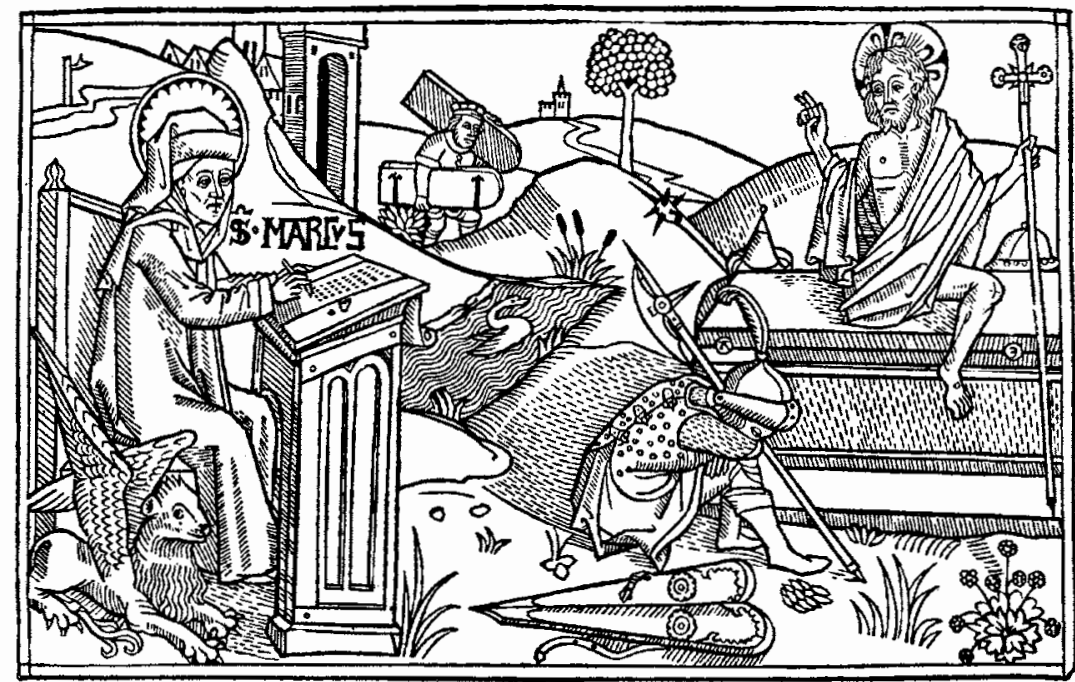

Evankelista Markus ja Jeesuksen ylösnousemus. Kuva on saksalaisesta Raamatusta 1400-luvun lopulta.

neuvostossa on käsitelty ehdotusta, että pääsiäinen olisi aina huhtikuun toisena sunnuntaina. Tämän päätöksen hyväksyminen vaatisi kuitenkin taakseen yli 200 jäsenkirkon yksimielisen tuen.

Toisena mahdollisuutena on ehdotettu, että pääsiäistä ruvettaisiin viettämään todellista kevätpäiväntasausta seuraavan todellisen täydenkuun jälkeisenä sunnuntaina. Todellisten taivaantapahtumien käyttäminen ei menneinä vuosisatoina ollut mahdollista, koska maapallon ja kuun liikkeitä ei osattu laskea tuleviksi vuosiksi tarpeeksi tarkasti eteenpäin. Tällä hetkellä tarkkuus jo riittää, ja tähtitieteilijät pystyvät laskemaan kevätpäiväntasaukset ja kuun vaiheet sadoiksi vuosiksi eteenpäin parin minuutin tarkkuudella.

Tähtitaivaan antama päivämäärä on täsmälleen sama kaikissa uskontokunnissa, kunhan vain sovitaan minkä paikkakunnan horisontin mukaan tähtitaivasta katsotaan. Kirkkojen maailmanneuvostossa 1997 on sovittu, että paikkakunta olisi Jerusalem. Sopivin ajanhetki uuden määritelmän käyttöönotolle olisi jokin vuosi, jolloin idän ja lännen pääsiäiset sattuvat samalle päivälle. Jos pääsiäiset tämän jälkeen määrättäisiin taivaan ilmiöiden mukaan, viettäisi koko läntinen kristikunta suurinta juhlaansa samana viikonloppuna. Päätös ei ole kuitenkaan toteutunut. 


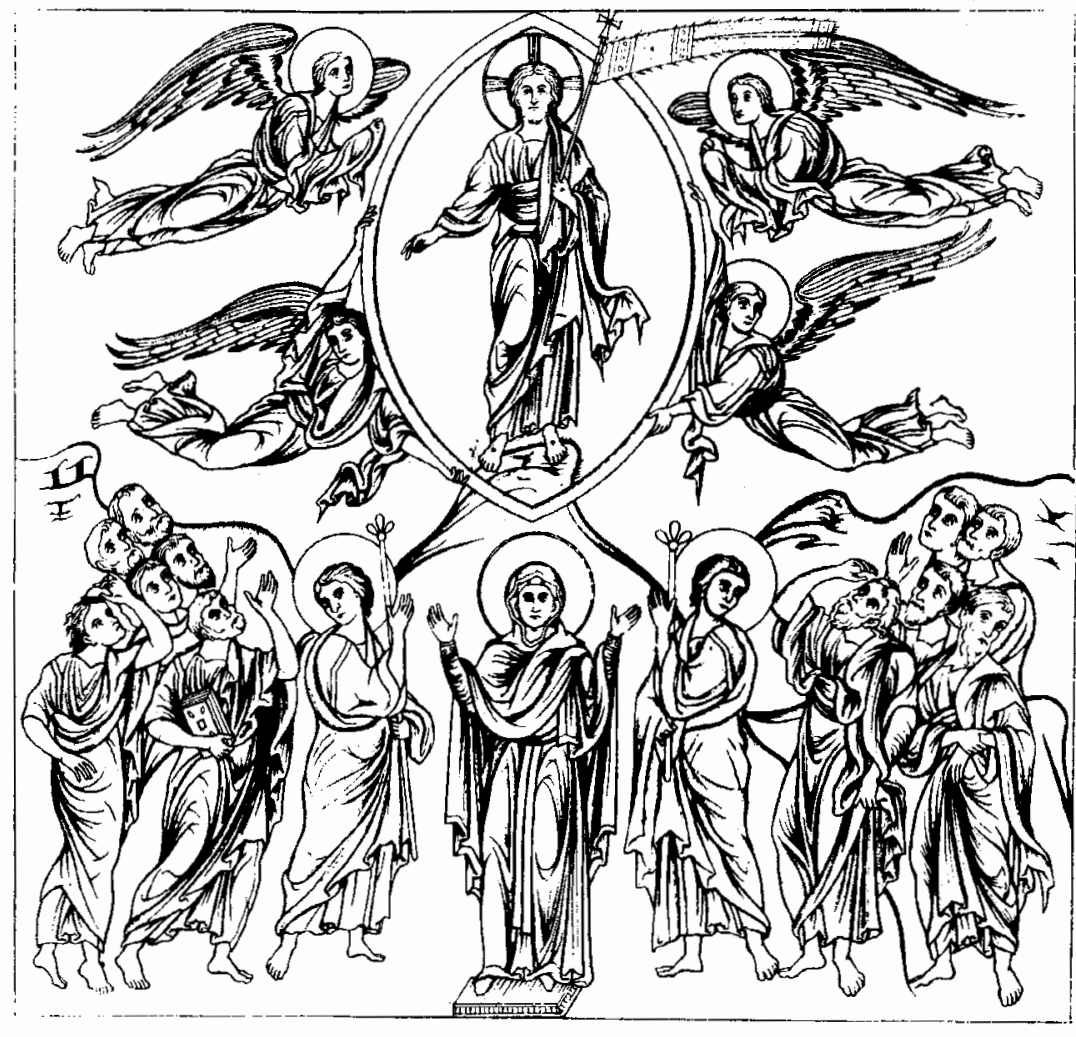

Helatorstaita vietetään Jeesuksen taivaaseenastumisen muistoksi. Kuva 1100-luvulta.

\section{Pääsiäisestä helluntaihin}

Pääsiäisen jälkivietto kestää helluntaihin asti eli 50 päivän ajan. Pääsiäisen ja helluntain välissä on rukoussunnuntai, joka on viisi viikkoa pääsiäissunnuntain jälkeen, ja helatorstai, joka on seuraavana torstaina, 39 päivää (roomalaisen laskutavan mukaan 40 päivää) pääsiäisen jälkeen.

Rukoussunnuntain nimi muuttui kirkon pyhäpäiväuudistuksessa, ja sen kohdalla lukee nykyään kalentereissa 5. sunnuntai pääsiäisestä. Päivän juuret ovat 400-luvulla, jolloin helatorstaita edeltäviä päiviä ruvettiin viettämään rukouspäivinä ja edeltävää sunnuntaita rukoussunnuntaina. Sunnuntain ja torstain välisiä päiviä sanottiin "käyntipäiviksi" tai kanttaipäiviksi, ja silloin järjestettiin rukouskulkueita, jotka rukoilivat siunausta alkavalle satokaudelle. Käyntipäivistä maanantai ja tiistai olivat Ruotsi-Suomessa puolipyhiä vielä 1700-luvulla. Almanakassa luki maanantain kohdalla punaisin kirjaimin Cant. wijk. (= kanttaiviikko). Vuonna 1772 kanttaimaanantai ja -tiistai muutettiin tavallisiksi arkipäiviksi.

Helatorstaita vietetään Jeesuksen taivaanseenastumisen muistoksi. Helatorstai on vanhan kansan mielestä ollut vuoden pyhin kirkkojuhla. Nimensäkin se on saanut ruotsin "pyhää" merkitsevästä sanasta.

Vuosina 1973-1991 helatorstain nimenä oli Kristuksen taivaaseenastumisen päivä ja sitä vietettiin viisi päivää aikaisemmin, lauantaipäivänä. Vuodesta 1992 helatorstaita on taas juhlittu perinteisellä, "oikealla" paikallaan.

\section{Helluntai ja kolminaisuudenpäivä}

Helluntaita vietetään Pyhän Hengen vuodattamisen muistoksi. Raamatun kertomuksen mukaan Jeesuksen opetuslapset saivat ensimmäisenä helluntaina Pyhän Hengen lahjan ja kastoivat tuhansia ihmisiä. Kirkko pitää helluntaita omana syntymäpäivänään, sillä tämä tapahtuma merkitsi ensimmäisen seurakunnan ja koko kristillisen kirkon syntymistä. Helluntai on edelleen alkuperäisellä paikallaan 49. (roomalaisen laskutavan mukaan 50.) päivänä pääsiäisestä.

Vuoteen 1972 asti almanakoissamme helluntai oli vanhaan tapaan kaksipäiväinen pyhä, jota vietettiin sunnuntaina ja maanantaina. $\mathrm{Ny}-$ kyään helluntaimaanantai on arkipäivä. Vuodesta 1973 vuoteen 1991 edelliselle lauantaille oli annettu pyhäpäivän luonne ja nimi helluntain valmistuspäivä. Vuodesta 1992 alkaen helluntai on ollut Suomessa yksipäiväinen juhla. Monessa muussa maassa helluntaimaanantai on edelleen pyhä- ja vapaapäivä.

Pyhän Kolminaisuuden päivä on helluntaita seuraava sunnuntai. Sen vietto sai alkunsa Englannissa 1100-luvulla ja levisi sieltä muihin maihin. Kirkkovuoden seuraavia sunnuntaipäiviä oli tapana sanoa kolminaisuudenpäivän jälkeisiksi sunnuntaiksi.

Uuden vuosituhannen myötä "kolminaisuudenpäivän jälkeiset sunnuntait" jäivät pois almanakoista, sillä kirkko muutti näidenkin pyhäpäivien nimet. Kirkkovuoden lopun sunnuntait numeroidaan nykyään helluntaista lähtien, kuten monessa muussakin länsimaassa tehdään. 


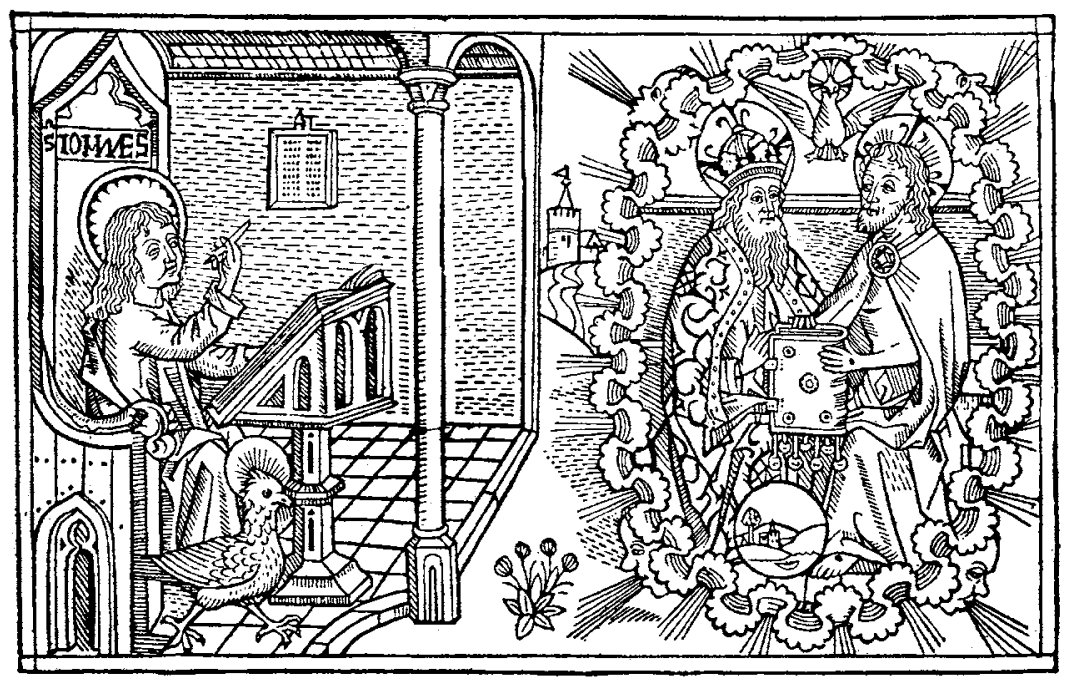

Evankelista Johannes ja Pyhä Kolminaisuus. Kuva saksalaisesta Raamatusta 1400-luvun lopulta.

Ensimmäinen sunnuntai helluntaista on Pyhän Kolminaisuuden päivä, ja helluntain jälkeisiä sunnuntaipäiviä on kirkkovuoden loppuun mennessä vähintään 23 ja enintään 26 kappaletta.

\section{Juhannuksesta kirkastussunnuntaihin}

Kirkko viettää juhannusta Johannes Kastajan syntymän muistoksi. Vanhan legendan mukaan Johannes Kastaja syntyi tasan puoli vuotta ennen Jeesusta.

Miksi Jeesuksen syntymäpäivä sitten on 25. päivänä ja Johannes Kastajan 24. päivänä? Selitys löytyy vanhasta roomalaisesta ajanlaskutavasta, joka oli käytössä tämän legendan syntyaikaan. Roomalaiset laskivat kuukauden lopun päivät taaksepäin seuraavan kuukauden alusta. Sekä joulupäivä että juhannuspäivä olivat roomalaisen laskutavan mukaan kahdeksantena päivänä ennen seuraavan kuun ensimmäistä päivää. Ero juhlien välillä oli siis tasan puoli vuotta. Mutta koska joulukuussa on 31 päivää ja kesäkuussa vain 30, saivat joulu ja juhannus myöhemmässä länsimaisessa ajanlaskussa eri päivänumeron.

Suomessa juhannus oli vuoteen 1954 asti vanhalla kiinteällä paikallaan

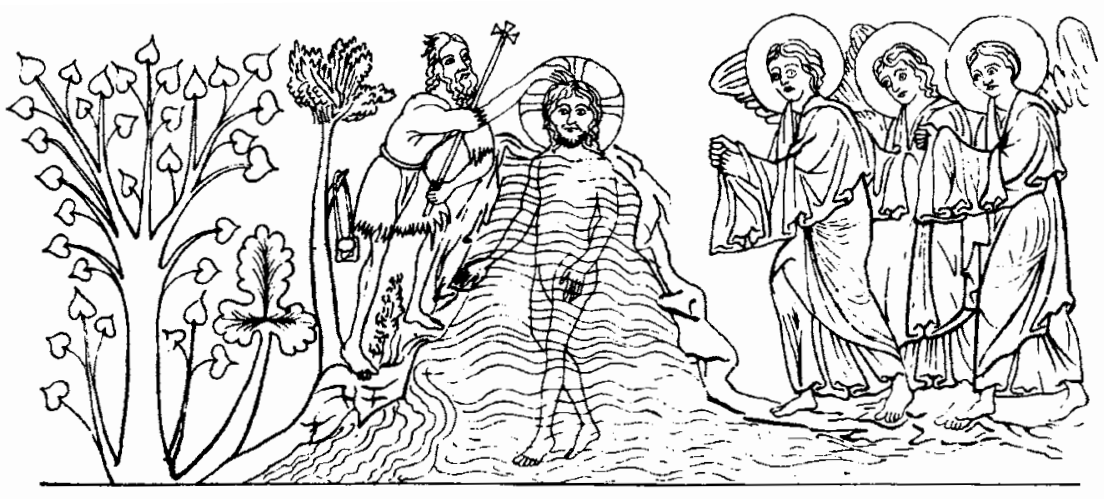

Kirkko viettää juhannusta Johannes Kastajan päivänä. Kuvassa Johannes kastaa Jeesuksen. Piirros 1100-luvulta.

24.6., kuten se on vieläkin esimerkiksi Norjassa ja Virossa. Vuodesta 1955 alkaen juhannuspäivää on meillä vietetty kesäkuun 20. ja 26. päivän väliin sattuvana lauantaina (tai kuten kirkkolaki sanoo, kesäkuun 19. päivää seuraavana lauantaina).

Juhannusta seuraavista pyhäpäivistä on nykyään kolmella oma nimi, kun ennen pyhäuudistusta erityinen nimi oli vain yhdellä (kirkastussunnuntailla).

Ensimmäinen nimetty pyhä on kuudes sunnuntai helluntaista, joka on nykyisessä evankeliumikirjassa merkitty Apostolien päiväksi. Tällöin kirkossa puhutaan apostolien kutsumisesta ja opetuslapsen tehtävästä. Apostolien päivä on aikaisimmillaan (kuten vuonna 2008) heti juhannusta seuraava päivä, myöhäisimmillään vasta heinäkuun lopulla.

Kirkastussunnuntaiksi sanotaan kahdeksatta sunnuntaita helluntaista. Nimensä se on saanut evankeliumeissa kerrotusta tapauksesta, jossa Jeesus ilmestyi kirkastuneena kolmelle oppilaalleen pyhällä vuorella.

Kirkastussunnuntain perinteinen paikka on elokuun 6. päivä, johon se on edelleen sijoitettu katolisessa ja ortodoksisessa kirkossa. Meillä kirkastussunnuntai voi olla niinkin aikaisin kuin heinäkuun 5. päivänä.

Kolmas kesäkauden erityispyhä on Luomakunnan sunnuntai. Nykyisen evankeliumikirjan mukaan sitä vietetään jonakin touko-elokuun sunnuntaina (vuodesta 2008 alkaen jonakin touko-lokakuun sunnuntaina). 


\section{Mikkelistä tuomiosunnuntaihin}

Mikkelinpäivä on syyskuun 29. päivä tai sitä lähinnä seuraava sunnuntai. Vuoteen 1772 asti se oli kiinteästi 29.9. Päivää vietetään arkkienkeli Mikaelin kunniaksi. Päivämäärä on saatu siitä päivästä, jolloin varhaisella keskiajalla Roomassa vihittiin Mikaelille omistettu kirkko.

Katolinen kirkko muistaa mikkelinpäivänä Mikaelin ohella kahta muuta enkeliä, Gabrielia ja Rafaelia. Nykyisessä evankeliumikirjassa mikkelinpäivän kohdalle on meilläkin merkitty lisänimi Enkelien sunnuntai. Enkeliaiheen ohella Suomen kirkoissa vietetään mikkelinpäivää lasten ja pyhäkoulutyön juhlana.

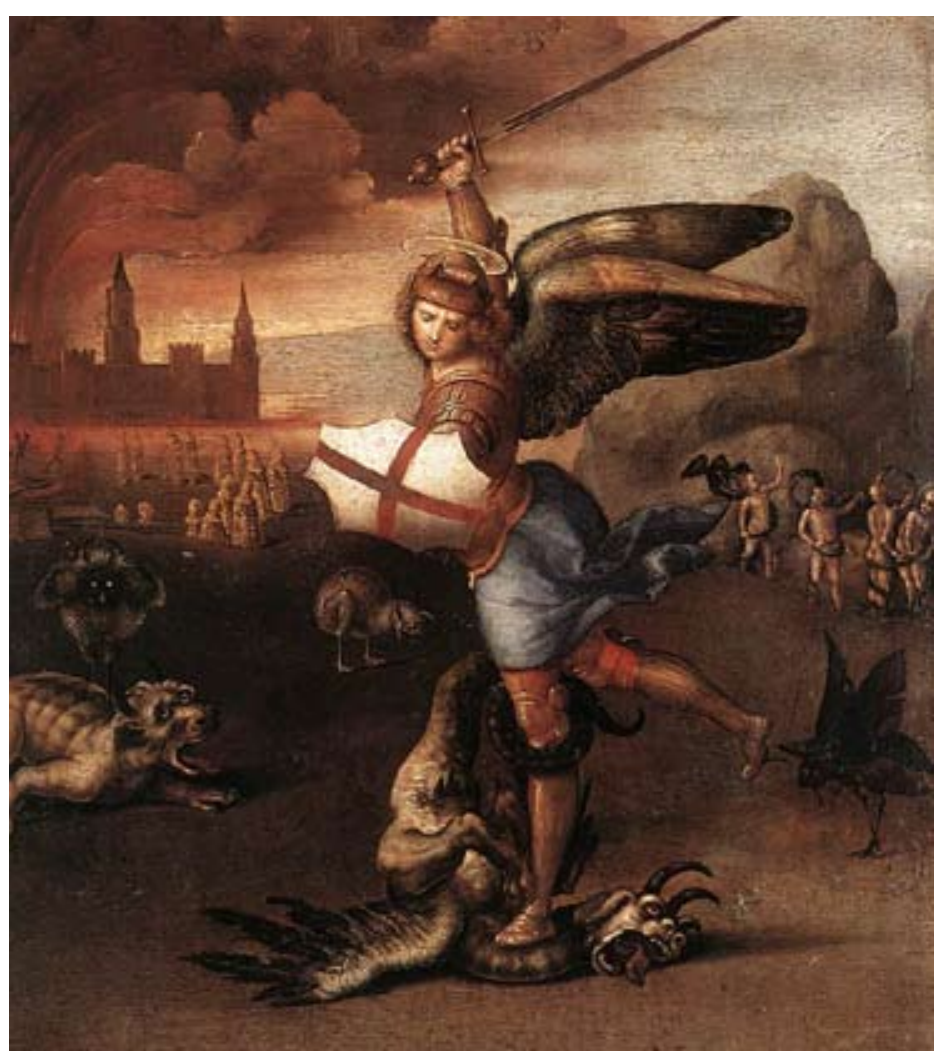

Arkkienkeli Mikael on taivaallisen sotajoukon päällikkö ja lohikäärmeen voittaja. Raphaelin maalaus. (Wikipedia)
Uuden vuosituhannen alussa koko perheelle annettiin oma pyhäpäivä. Kirkon pyhäuudistuksessa päätettiin, että jokin syys-marraskuun sunnuntai (vuodesta 2008 alkaen touko-marraskuun sunnuntai) voidaan omistaa erityisesti lapsille ja perheelle. Pyhän nimeksi tuli Perheen sunnuntai.

Pyhäuudistus toi syksyyn toisenkin uuden juhlan. Uskonpuhdistuksen muistopäiväksi sanotaan 22. sunnuntaita helluntaista.

Loka-marraskuun vaihteessa vietetään kirkossa pyhäinpäivää. Pyhäinpäivässä on yhdistetty kaksi kirkon vanhaa juhlaa: kaikkien marttyyrien yhteinen päivä ja kaikkien uskovien vainajien muistopäivä. Marttyyrien eli pyhien päivää on vietetty marraskuun 1. päivänä 700-luvun lopulta lähtien. Se sai alkunsa, kun kaikille marttyyreille ei enää riittänyt omaa päivää. Vainajien päivää on taas vietetty toisen vuosituhannen alusta lähtien marraskuun 2. päivänä.

Ruotsi-Suomessa nämä kaksi juhlaa yhdistettiin yhdeksi pyhäinmiestenpäiväksi, jota vietettiin 1.11. Pyhäinpäivää eli kekriä pidettiin yhteen aikaan maaseudulla uuden vuoden päivänä, jolloin satokausi ja työvuosi oli saatu loppuun.

Nykyään pyhäinpäivänä on tapana muistaa vainajia ja viedä seppeleitä tai kynttilöitä omaisten haudoille.

Pyhäinmiestenpäivä oli aluksi kiinteä juhla, mutta vuoden 1772 kalenteriuudistuksessa se sijoitettiin vietettäväksi lähinnä seuraavalle sunnuntaille. Almanakat merkitsivät pyhäinmiestenpäivän kahteen paikkaan, 1.11. ja jos tämä ei ollut sunnuntai myös seuraavalle sunnuntaille. Vuodesta 1955 alkaen päivän nimi ja sijainti on vaihtunut. Siitä tuli pyhäinpäivä ja se sijoitettiin lokakuun 31. ja marraskuun 6. päivän väliselle lauantaille (tai kuten kirkkolaki sanoo, lokakuun 30. päivää seuraavaan lauantaihin).

Kirkkovuoden lähinnä viimeinen sunnuntai sai 2000-luvun alussa uudeksi nimekseen Valvomisen sunnuntai. Evankeliumikirjan mukaan tämän sunnuntain sanoma korostaa hengellistä valvomista ja Kristuksen paluun odotusta.

Viimeinen sunnuntai ennen adventtia on nimetty tuomiosunnuntaiksi. Se on kirkkovuoden viimeinen sunnuntai, jonka tekstit käsittelevät viimeistä tuomiota.

Kaikissa maissa ei kirkkovuoden viimeisenä sunnuntaina ajatella tuomiopäivää. Virossa muistellaan kuolleita, katolisessa kirkossa puhutaan 
Kristuksen kuninkuudesta ja Saksassa kymmenestä neitsyestä. Meidän pyhäuudistuksessamme tuomiosunnuntain nimeen tuli myös lisämääre Kristuksen kuninkuuden sunnuntai.

\section{Joulun tulo}

Adventista alkaa joulunaika. Adventti eli tulo, saapuminen, merkitsi alkuaan keväisen laskiaisen vastinetta. Kun keväällä valmistauduttiin paastoamalla pääsiäisen piinaviikkoa varten, piti talvella valmistautua katuen ja parannusta tehden vastaanottamaan Kristus-lasta. Myös adventtiaikaan liittyi keskiajalla paastoaminen (ns. pieni paasto erotukseksi pääsiäisen suuresta paastosta), ja sen muistona meilläkin vielä syödään ennen joulua lipeäkalaa.

Ensimmäinen adventtisunnuntai on marraskuun 30. päivää lähinnä oleva sunnuntai (aikaisintaan 27.11. ja viimeistään 3.12.). Joulua ennen ehtii olla kaikkiaan neljä adventtisunnuntaita.

\section{Milloin Jeesus syntyi? \\ Betlehemin tähden arvoitus}

eesuksen tarkkaa syntymäaikaa tai -vuotta ei tunneta. Syntymäpäivä on tuskin ollut 25. joulukuuta, vaan tämä päivämäärä on valittu paljon myöhemmin muista syistä. Arvelut syntymävuodestakin vaihtelevat melkoisesti. Välillä on arvioitu, että Jeesus on voinut syntyä jopa 7 vuotta ennen ajanlaskumme alkua, toiset lähteet arvelevat syntymävuodeksi vuotta 3 tai $2 \mathrm{eKr}$.

Matteuksen evankeliumissa on kertomus Betlehemin tähdestä, ja tähtitieteilijät ovat sen avulla koettaneet ajoittaa syntymävuotta. Jotkut tutkijat ovat sitä mieltä, että Betlehemin tähdellä ei ole luonnontieteellistä vastinetta. Kyseessä on voinut olla vain kaunis myytti, taru. Tällöin vuoden ajoittaminen ei tietenkään onnistu tähtien avulla.

Useat kuitenkin arvelevat, että kyseessä oli todellinen taivaan valo. Tähteä on pidetty milloin kirkkaana komeettana eli pyrstötähtenä, milloin supernovana eli räjähtävänä tähtenä. Sellaiset voivat ilmestyä taivaalle pariksi viikoksi tai kuukaudeksi ja kadota sitten taas näkyvistä. Tällaisista ilmestyksistä kyseisenä ajankohtana ei kuitenkaan ole löydetty merkintöjä aikakirjoista miltään puolelta maapalloa.

Suosituin tähtitieteellinen selitys Betlehemin tähdelle on kahden kirkkaan planeetan kohtaaminen. Vaikka planeettojen kohtaaminen ei yleensä ole kovin silmäänpistävä näky, tapahtumaa on jälkeenpäin voitu suurennella, koska se oli merkkinä niin tärkeästä hetkestä kuin Jeesuksen syntymästä.

Betlehemin tähti oli Raamatun mukaan näkyvissä pitkän aikaa, ja siksi yksinkertainen planeettojen kohtaaminen ei voi tähteä selittää. Planeetat kuitenkin tekevät taivaalla silmukoita, ja silloin voi sattua, että kuukausien välein kaksi planeettaa kohtaa toisensa useaankin kertaan.

Johannes Keplerin laskelmista alkaen (1600-luvun alusta) on parhaana

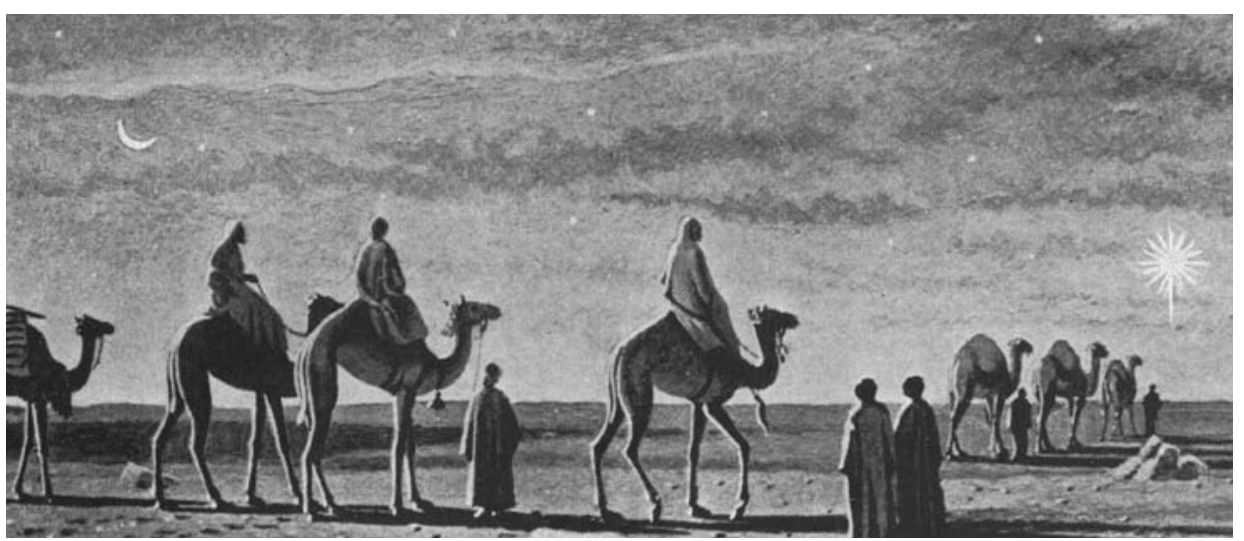

selityksenä Betlehemin tähdelle pidetty Jupiterin ja Saturnuksen kolminkertaista kohtaamista vuonna 7 eKr. Planeetat olivat tuolloin Kalojen tähdistössä. Ensimmäinen kohtaus oli keväällä, toinen syksyllä ja kolmas joulukuun alussa.

Lääninrovasti Risto Heikkilä, joka on myös tunnettu tähtiharrastaja, on tullut toisenlaiseen tulokseen. Hänen mukaansa viime aikoina on saatu Jeesuksen syntymäaikojen historiasta runsaasti uutta tietoa, ja sen mukaan Jeesuksen todennäköinen syntymävuosi on ollut 3 tai 2 eKr. Vuoden 3 elokuussa kohtasi kaksi kirkkainta planeettaa, Jupiter ja Venus, Leijonan tähdistössä. Seuraavan vuoden kesäkuun 17. päivänä planeetat kohtasivat uudelleen ja sulautuivat nyt yhdeksi tähdeksi. Kohtaaminen tapahtui läntisellä taivaalla, Babylonian tietäjien asuinalueelta katsottuna Jerusalemin suunnalla. "Betlehemin tähti on siten kuningasplaneetta Jupiter", arvelee Heikkilä.

Jos eräät IImestyskirjan jakeet tulkitaan tähtitieteen avulla kirjaimellisesti, voidaan Jeesuksen syntymäpäiväkin ajoittaa tarkasti, syyskuun 11. päiväksi vuonna 3 eKr. 
Adventti on kirkon uudenvuodenpäivä, koska se aloittaa uuden kirkkovuoden. Adventin jumalanpalveluksissa ja koulujen hartaustilaisuuksissa kaikuu silloin kaunis Hoosianna-hymni.

Joulu, Jeesuksen syntymän muistopäivä, on kiinteästi 25 . joulukuuta. Sen paikka määrättiin Roomassa 300-luvulla, ja joulun vietto levisi nopeasti suureen osaan kristikuntaa. Joulukuun lopulla oli aikaisemmin vietetty pakanallisia keskitalven juhlia, ja niiden tilalle kirkko tarjosi yhtä iloista kristillistä juhlaa. Joulujuhla voittikin nopeasti niin roomalaisen saturnaliajuhlan ja voittamattoman auringon päivän kuin pohjoisten kansojen keskitalven juhlan.

Toinen joulupäivä, tapaninpäivä, pyhitettiin ensimmäisen marttyyrin Stefanuksen muistolle. Tälllä pohjoisessa sitä on vietetty myös hevosten ja hevosmiesten päivänä, mistä vieläkin on muistona tapaninajelu.

Joulujuhla oli alkuun useampipäiväinen juhla, joka jatkui uuteenvuoteen asti. Vuoden 1772 kalenteriuudistuksessa joulu lyhennettiin Ruotsi-Suomessa nelipäiväisestä kaksipäiväiseksi juhlaksi. Aikaisemmat 3. ja 4. joulupyhä eli Johannes Evankelistan ja viattomien lasten päivä muutettiin arkipäiviksi. Kansa mielsi ne kuitenkin pitkään pyhäpäiviksi;

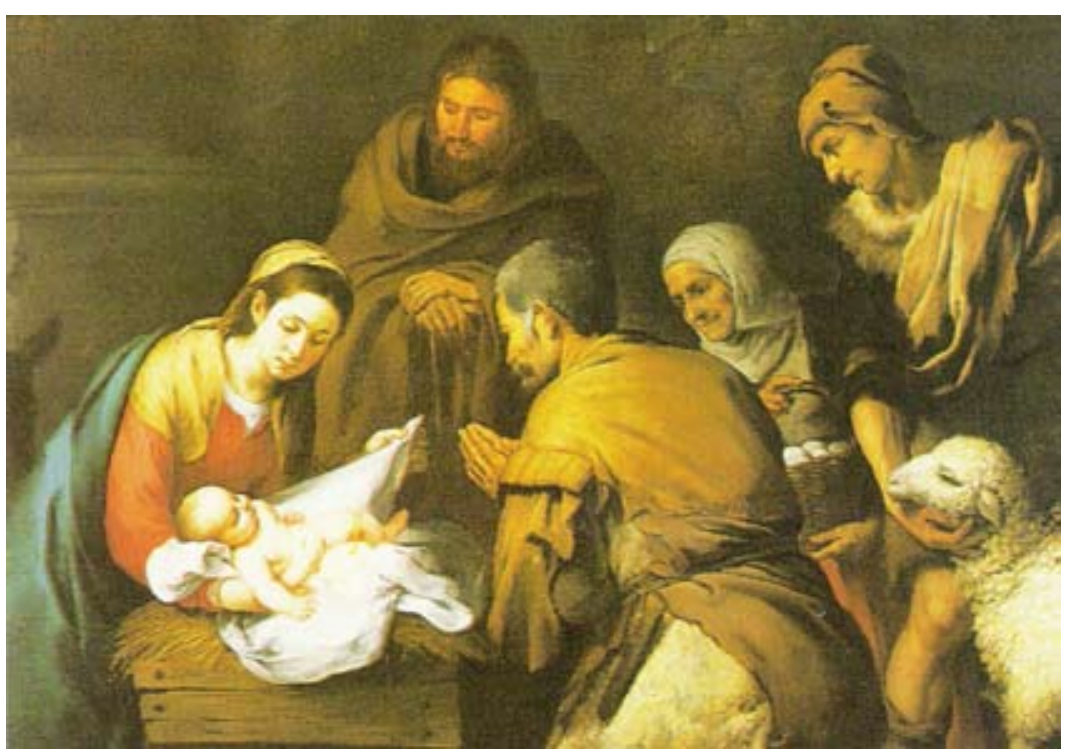

Paimenet tervehtivät vastasyntynyttä Jeesusta. Bartolomé Esteban Murillon maalaus 1600-luvulta. (Wikipedia) puhuttiin "arkipyhistä".

Merkintä Johannes Evankelistan päivästä tipahti pois Suomen almanakoista 1920-luvun lopulla (joskin Johanneksesta lyhennetyt Hannu ja Hannes saivat nimipäivän tälle päivälle). Sen sijaan viattomien lasten päivä on sinnitellyt mukana nykypäivään asti. Aiheensa viattomien lasten päivä on saanut Raamatusta, jossa kerrotaan, miten Herodes surmautti Betlehemin poikalapset yrittäessään tappaa vastasyntyneen Jeesuksen.

Kirkon uudessa evankeliumikirjassa 3. ja 4. joulupäivä ovat jälleen mukana. Kolmannen joulupäivän nimenä on nyt Apostoli Johanneksen päivä. Päivät pysyvät toki arkipäivinä, mutta jos jompikumpi niistä sattuu joulun jälkeiseen sunnuntaihin, päivä saa 3. tai 4. joulupäivän nimen ja jumalanpalvelustekstit.

\section{Siirretyt juhlapäivät}

Suomalaisissa almanakoissa on useaan otteeseen muutettu pyhäpäivien luonnetta tai sijoittelua. Ensimmäiset siirrot tapahtuivat Kustaa III:n aikana 1772, kun hallitusmiesten mielestä vuoden varrelle oli kertynyt aivan liikaa työrytmiä rikkovia juhlapäiviä. Siksi lakkautettiin "ihmismääräykseen perustuvat pyhäpäivät" ja eräitä Raamattuunkin perustuvia siirrettiin keskeltä viikkoa viikonlopuksi.

Arkipäiviksi muutettiin noin 20 pyhää, mm. kaikkien apostolien päivät ja kolmas ja neljäs joulu-, pääsiäis- ja helluntaipäivä. Kynttilänpäivä, mikkelinpäivä ja pyhäinmiestenpäivä siirrettiin kiinteältä paikalta sunnuntaille.

Seuraava suurempi muutos tapahtui vuoden 1955 almanakassa, jolloin muuttui marianpäivän ja juhannuksen paikka. Niitä pidettiin kirkkojuhlista helpoimmin liikuteltavina, ja ne siirrettiin viikonloppuun. Marianpäivä muuttui sunnuntaille, Johannes Kastajan päivä lauantaille. Samalla pyhäinmiestenpäivä siirrettiin sunnuntaista lauantaihin.

Seuraava siirto tehtiin vuoden 1973 alusta, kun loppiainen, helatorstai ja toinen helluntaipäivä saivat uudeksi paikakseen lauantain.

Perusteluna muutoksille on ollut työntekijöiden ja työnantajien halu saada vuoden varrelle mahdollisimman paljon ehjiä työviikkoja. Työmarkkinaneuvotteluissa tuotti ainaista kiusaa eri päiville sattuneiden pyhien korvaaminen. Joskus pyhät olivat arkena ja veivät yhden työpäivän, joskus taas viikonloppuna, jolloin työntekijät jäivät vaille vapaapäivää. 
Kirkon piirissä ei pyhäpäivien siirtelyä ole katsottu suopeasti. Vuoden 1973 ratkaisussa kirkko oli lähinnä pakkotilanteessa ja joutui vastahakoisesti myöntymään muutokseen. Myöhemmin siirtoja haluttiin perua. Jo syksyllä 1981 pidetty piispainkokous keskusteli vakavasti, miten paluu entiseen voitaisiin toteuttaa. Seuraavina vuosina kirkko onnistui taivut- telemaan kansanedustajat puolelleen. Eduskunta päätti syksyllä 1985, että loppiainen ja helatorstai palautetaan entisille paikoilleen ja helluntai typistetään yksipäiväiseksi juhlaksi. Pyhäpäivä on vain helluntaisunnuntai, mutta ei enää sen enempää lauantai kuin maanantaikaan.

Työmarkkinajärjestöt eivät pitäneet päätöksestä, ja presidentti Mauno

\section{Pyhäuudistukset pähkinänkuoressa}

Vuoden 1772 uudistus (näkyi vuoden 1774 almanakasta alkaen) Pyhäpäivä

25.1. Apostoli Paavali

2.2. Kynttilänpäivä

24.2. Apostoli Mattias

Kiirastorstai

Kolmas pääsiäispäivä (tiistai)

Neljäs pääsiäispäivä (keskiviiikko)

Kanttaimaanantai

Kanttaitiistai

1.5. Apostolit Filippus ja Jaakob

Kolmas helluntaipäivä (tiistai)

Neljäs helluntaipäivä (keskiviikko)

29.6. Apostolit Pietari ja Paavali

2.7. Marian etsikkopäivä

25.7. Apostoli Jaakob

24.8. Apostoli Bartolomeus

21.9. Apostoli Matteus

29.9. Mikkelinpäivä

28.10. Apostolit Simon ja Juudas

1.11. Pyhäinmiestenpäivä

30.11. Apostoli Andreas

21.12. Apostoli Tuomas

27.12. Kolmas joulupäivä,

Apostoli Johannes

28.12. Neljäs joulupäivä,

viattomien lasten päivä muutos

muuttui arjeksi

siirtyi seuraavaksi sunnuntaiksi

muuttui arjeksi

muuttui arjeksi

muuttui arjeksi

muuttui arjeksi

muuttui arjeksi

muuttui arjeksi

muuttui arjeksi

muuttui arjeksi

muuttui arjeksi

muuttui arjeksi

muuttui arjeksi

muuttui arjeksi

muuttui arjeksi

muuttui arjeksi

siirtyi seuraavaksi sunnuntaiksi

muuttui arjeksi

siirtyi seuraavaksi sunnuntaiksi

muuttui arjeksi

muuttui arjeksi

muuttui arjeksi

muuttui arjeksi

Vuoden 1954 uudistus (vuoden 1955 almanakasta alkaen) 25.3. Marian ilmestyspäivä

siirtyi sunnuntaiksi ja muuttui marianpäiväksi
24.6. Johannes Kastajan päivä

1.11. Pyhäinmiestenpäivä

siirtyi lauantaiksi

siirtyi lauantaiksi ja muuttui pyhäinpäiväksi

Vuoden 1972 uudistus (vuoden 1973 almanakasta alkaen)

6.1. Loppiainen

Helatorstai

siirtyi lauantaiksi

siirtyi lauantaiksi ja muuttui Kristuksen taivaaseenastumisen päiväksi

Toinen helluntaipäivä siirtyi lauantaiksi ja muuttui helluntain valmistuspäiväksi

Vuoden 1986 uudistus (vuoden 1992 almanakasta alkaen)

Loppiainen

palasi vanhalle paikalleen torstaiksi

ja sai vanhan nimensä

Helluntain valmistuspäivä poistettiin
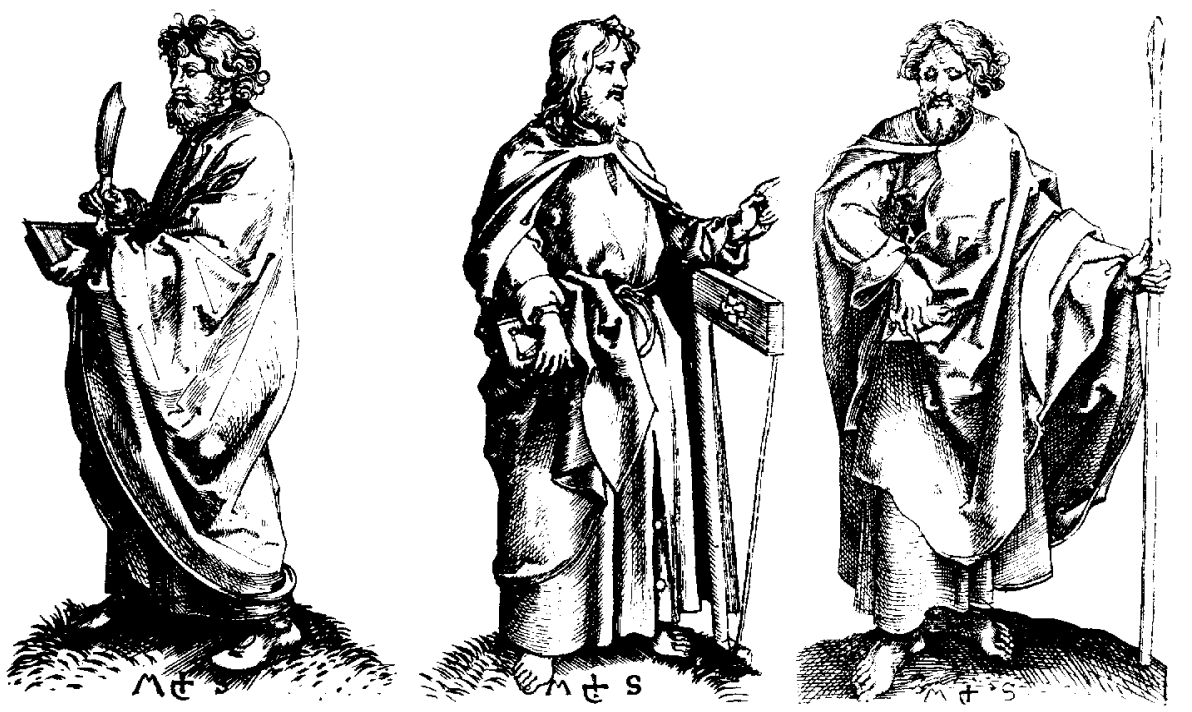

Apostolit Bartolomeus, Jaakob nuorempi ja Tuomas 1400-luvun kuparipiirroksessa. 
Koivisto tunsi sympatiaa niitä kohtaan. Koska eduskunta oli jättänyt lain voimaantulovuoden määräämättä, Koivisto lopulta vahvisti lain helmikuussa 1986, mutta päätti, että se astuu voimaan vasta vuoden 1992 alusta.

Suomalainen pyhien siirtely on ainutlaatuista maailmassa. Useissa muissa Länsi-Euroopan maissa ja esimerkiksi Yhdysvalloissa käytäntö on sellainen, että kukin uskontokunta viettää juhliaan perinteisinä päivinään, mutta päivät ovat arjelle sattuessaan normaaleja työpäiviä.

Vastineeksi juhlapäivien työnteosta on monessa maassa sovittu viikonloppujen yhteyteen korvaavia vapaapäiviä. Esimerkiksi Englannissa on kolme maanantaita merkitty kansallisiksi vapaapäiviksi ilman että niille annetaan minkään kirkollisen pyhän nimeä.

Englannissa ja esimerkiksi Australiassa käytetään omaa ratkaisua myös sille, että joulu välillä on arkena ja välillä viikonloppuna. Joulu on katsottu niin suureksi juhlaksi, että sen kunniaksi on joka vuosi saatava kaksi vapaapäivää. Niinpä esimerkiksi 2010, jolloin joulupäivät olivat lauantai ja sunnuntai, näissä maissa oli vapaata 27. ja 28.12. eli maanantaina ja tiistaina.

Suurimpiin kirkon juhliin, pääsiäiseen ja jouluun, ei suomalaisessa pyhien siirtelyssä ole kajottu. Pääsiäinenhän on jo nykyään sidottu viikonloppuun, ja joulun viettoon nykyisellä paikalla liittyy ilmeisesti jo niin paljon perinteitä, ettei sen muuttamiseen ole mahdollisuutta. Lähellähän on joka tapauksessa vuodenvaihde, jota ei ilman koko kalenterin syvällistä muutosta saada vakituisesti viikonloppuun.

\section{Pyhien ihmisten muistopäivät}

Varsinaisen kirkkovuoden rinnalla kulkee kristillisissä kirkoissa toinen merkittävä kalenteri, pyhimyskalenteri. Pyhimyksiä syntyi varsinkin kristillisen kirkon alkuaikoina sadoittain, kunnes lopulta vuosi oli täynnä heidän päiviään. Kunkin päivän kohdalle sattuvat tärkeimmät pyhimykset lueteltiin kalentereissa, ja näiden pyhimysluetteloiden pohjalta on esimerkiksi Suomessa kehittynyt nimipäiväluettelo.

Luterilainen kirkko ei pyhimyksiä hyväksynyt. Siksi Suomessa ei enää pitkiin aikoihin ole ollut virallista pyhimysluetteloa.

Kun 1990-luvun lopulla uudistettiin mm. kirkkokäsikirjaa ja jumalanpalveluksia, laadittiin samalla uusi kirkollinen muistopäiväkalenteri.

\begin{tabular}{|c|c|}
\hline ded & $\begin{array}{l}\text { Kirkollinen } \\
\text { muistopäiväkalenteri }\end{array}$ \\
\hline \multicolumn{2}{|r|}{ Tammikuu } \\
\hline 2 & Wilhelm Löhe 1872, teologi, luterilaisen kirkon uudistaja \\
\hline 13 & Hilarius Poitierslainen 367, piispa, uskonopettaja \\
\hline 15 & $\begin{array}{l}\text { Martin Luther King 1968, yhteiskunnal- } \\
\text { linen uudistaja, marttyyri }\end{array}$ \\
\hline 19 & Henrik 1156, piispa, marttyyri \\
\hline 25 & Apostoli Paavali \\
\hline 26 & Timoteus ja Titus, Paavalin työtoverit \\
\hline 27 & $\begin{array}{l}\text { Paavo Ruotsalainen 1852, herännäi- } \\
\text { syyden isä }\end{array}$ \\
\hline \multicolumn{2}{|c|}{ Helmikuu } \\
\hline 2 & Kynttilänpäivä \\
\hline 3 & $\begin{array}{l}\text { Ansgar 865, uskon sanansaattaja } \\
\text { Pohjolassa }\end{array}$ \\
\hline 5 & $\begin{array}{l}\text { Johan Ludvig Runeberg, s. 1804, } \\
\text { kansallisrunoilija, virsirunoilija }\end{array}$ \\
\hline 18 & Martti Luther, uskonpuhdistaja 1546 \\
\hline 21 & $\begin{array}{l}\text { Lars Levi Laestadius 1861, pappi, } \\
\text { lestadiolaisuuden isä }\end{array}$ \\
\hline 23 & Polykarpos n. 155, piispa, marttyyri \\
\hline 24 & $\begin{array}{l}\text { (Puuveistos, kuva Nousiais- } \\
\text { ten seurakunta) }\end{array}$ \\
\hline \multicolumn{2}{|c|}{ Maaliskuu } \\
\hline 12 & Gregorius Suuri 604, Rooman piispa, kirkkolaulun edistäjä \\
\hline 18 & Kyrillos Jerusalemilainen 386, piispa, kirkonopettaja \\
\hline 19 & Joosef, Herran äidin Marian puoliso \\
\hline 20 & Uppsalan kokouksen päätös 1593 \\
\hline 21 & Benedictus Nursialainen 547, munkiston perustaja, sielunhoitaja \\
\hline 24 & Oscar Romero 1980, piispa, marttyyri \\
\hline 25 & Marian ilmestyspäivä \\
\hline \multicolumn{2}{|c|}{ Huhtikuu } \\
\hline 7 & Johann Hinrich Wichern 1881, sisälähetyksen isä \\
\hline 9 & $\begin{array}{l}\text { Mikael Agricola 1557, piispa, Suomen uskonpuhdistaja, kirja- } \\
\text { kielen perustaja }\end{array}$ \\
\hline 9 & Elias Lönnrot, s. 1802, kansallinen herättäjä, virsikirjan uudistaja \\
\hline 9 & Dietrich Bonhoeffer 1945, teologi, marttyyri \\
\hline 19 & Olavus Petri 1552, Ruotsin uskonpuhdistaja \\
\hline
\end{tabular}


19 Philipp Melanchthon 1560, professori, Lutherin työtoveri

25 Evankeliuminkirjoittaja Markus

\section{Toukokuu}

2 Athanasios 373, piispa, kirkonopettaja

3 Apostolit Filippus ja Jaakob nuorempi

9 Nicolaus Ludwig von Zinzendorf 1760, herrnhutilaisuuden perustaja

11 Johann Arndt 1621, hartauskirjailija

13 Aurora Karamzin 1902, diakonissalaitoksen perustaja

22 Hemming 1366, Turun piispa

27 Paul Gerhardt 1676, pappi, virsirunoilija

\section{Kesäkuu}

1 Justinus n. 165, roomalainen marttyyri

2 Kirkollisen kansanopetuksen päivä, Söderköpingin piispainkokouksen päätös 1441

8 August Hermann Francke 1727, pietismin isiä

9 Efraim Syyrialainen 373, idän kirkkoisä, hymnirunoilija

11 Apostoli Barnabas

14 Itäisen kirkon isät Basileios Suuri 379, Gregorios Nazianzilainen n. 389 ja Gregorios Nyssalainen n. 385

24 Johannes Kastajan syntymä

25 Augsburgin tunnustus 1530

28 Irenaeus n. 202, piispa, marttyyri

29 Apostoli Pietari

\section{Heinäkuu}

2 Marian vierailu Elisabetin luona

6 Jan Hus 1415, uskonpuhdistuksen edelläkävijä, marttyyri

12 Nathan Söderblom 1931, Ruotsin arkkipiispa, kristittyjen yhteyden edistäjä

20 Ensimmäinen suomalainen kokoraamattu 1642

22 Magdalan Maria

24 Tuomas Kempiläinen 1471, hartauskirjailija

25 Apostoli Jaakob vanhempi

28 Johann Sebastian Bach 1750, kanttori, kirkkomusiikin mestari

29 Olavi, Erik ja Knut, pohjoismaiset marttyyrikuninkaat

\section{Elokuu}

8 Dominicus 1221, pappi, sääntökunnan perustaja

10 Laurentius 258, roomalainen diakoni, marttyyri

14 Florence Nightingale 1910, yhteiskunnallinen uudistaja

17 Missale Aboense 1488, ensimmäinen Suomea varten painettu kirja (Konrad Bitzin esipuheen päiväys)
19 Fredrik Gabriel Hedberg 1893, pappi, evankelisen liikkeen isä

20 Bernhard Clairvauxlainen 1153, kirkonopettaja, Jumalan rakkauden saarnaaja

24 Apostoli Bartolomeus

27 Monica 387, Augustinuksen äiti

28 Augustinus 430, piispa kirkkoisä

29 Johannes Kastajan mestaus

\section{Syyskuu}

4 Albert Schweitzer 1965, teologi, lähetystyöntekijä

12 Jaakko Finno (k. syyskuussa 1588) kirkollisen kirjallisuuden edistäjä, Suomen ensimmäisen virsikirjan tekijä

13 Johannes Khrysostomos 407, piispa, kirkonopettaja

18 Otto Aarnisalo 1942, sisälähetystyön uranuurtaja, diakonian päivä

21 Apostoli ja evankeliuminkirjoittaja Matteus

28 Abraham Achrenius 1769, pappi, virsirunoilija

29 Arkkienkeli Mikael ja kaikki enkelit

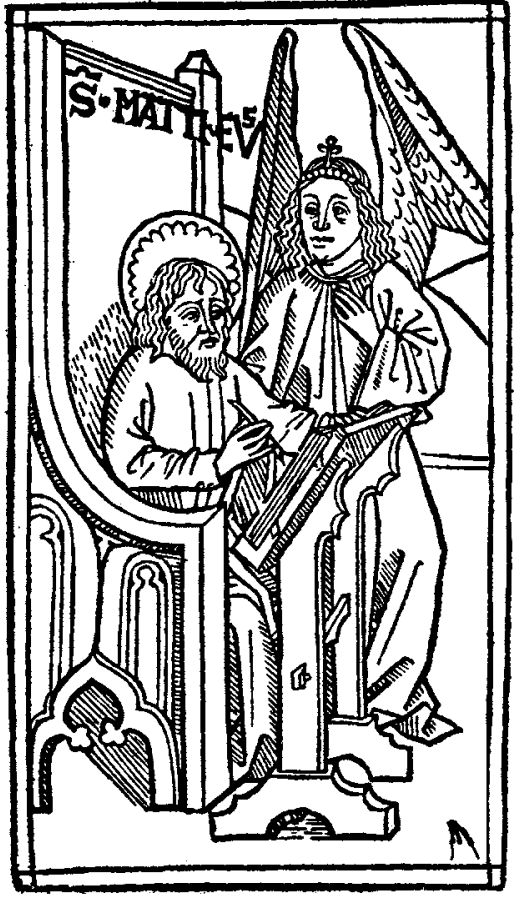

Evankelista Matteus saksalaisessa Raamatussa 1400-luvulta.

\section{Lokakuu}

4 Franciscus Assisilainen 1226, fransiskaaniveljestön perustaja, Kristuksen köyhyyden todistaja

5 Theodor Fliedner 1864, diakonissalaitosten isä, yhteiskunnallinen uudistaja

Birgitta 1373, sääntökunnan perustaja

Ignatius n. 115, piispa, marttyyri

Evankeliuminkirjoittaja Luukas

Martti Rautanen (1926), "Ambomaan apostoli"; suomalaisen lähetystyön päivä

27 Laurentius Petri 1573, Ruotsin ensimmäinen luterilainen arkkipiispa Apostolit Simon Kananeus ja Juudas Jaakobinpoika Uskonpuhdistuksen muistopäivä 1517 


\begin{tabular}{|c|l|}
\hline Marraskuu \\
1 & Pyhäinpäivä \\
5 & Henrik Renqvist 1866, pappi, hengellisen kirjallisuuden edistäjä \\
22 & Kirkkomusiikin päivä (Cecilia) \\
23 & Clemens Roomalainen n. 100, piispa, marttyyri \\
24 & Inkerin kirkon marttyyrit \\
30 & Apostoli Andreas \\
Joulukuu \\
7 & Ambrosius, piispa, kirkonopettaja 397 \\
14 & Ristin Johannes 1591, mystikko \\
21 & Apostoli Tuomas \\
26 & Ensimarttyyri Stefanos \\
26 & Mathilda Wrede 1928, vankien ystävä \\
27 & Apostoli ja evankeliuminkirjoittaja Johannes \\
28 & Viattomien lasten päivä \\
31 & John Wycliff 1384, uskonpuhdistaja \\
\end{tabular}

Se ei kuitenkaan lopulta tullut mukaan evankeliumikirjaan, vaan jäi ehdotukseksi, jota yhä kehitellään.

Oheisessa laatikossa on kirkon käsikirjakomitean ehdotus uskossaan esikuvallisten ihmisten muistopäiviksi. Henkilöiden muistopäivät ovat yleensä heidän kuolinpäiviään, kuten aikaisemmissa pyhimysluetteloissa, koska kuolinpäivänä pyhimykset syntyivät ikuiseen elämään. Jos kuolinpäivä ei ole tiedossa, on luettelossa seurattu perinnettä.

Muistopäiväluettelosta löytyy marttyyreja, esimerkiksi piispa Henrik, jonka Lalli surmasi 1156, tai Martin Luther King, joka sai surmansa 1968. Sieltä löytyvät myös 12 apostolia, joiden päivät pudotettiin pois Suomen pyhäpäiväluettelosta 1700-luvulla, sekä tärkeimpiä suomalaisia ja kansainvälisiä uskon uudistajia ja herätysliikkeiden perustajia.

Muistopäiväluetteloon on myös otettu alkuperäisille paikoilleen sellaisia pyhiä, jotka ovat meillä muuttuneet liikkuviksi juhliksi (kynttilänpäivä 2.2., Marian ilmestyspäivä 25.3., pyhäinpäivä 1.11.) tai jotka on meidän kalentereistamme aikoinaan kokonaan poistettu (Marian vierailu Elisabetin luona 2.7.).

\section{Rukouspäivät ja itsenäisyyspäivä}

Tässä luvussa on puhuttu kirkkovuodesta, joka muodostaa oman kokonaisuuden adventista adventtiin, ja pyhien ihmisten muistokalenterista,
Apostoli Pietari 1800-luvun piirroksessa.

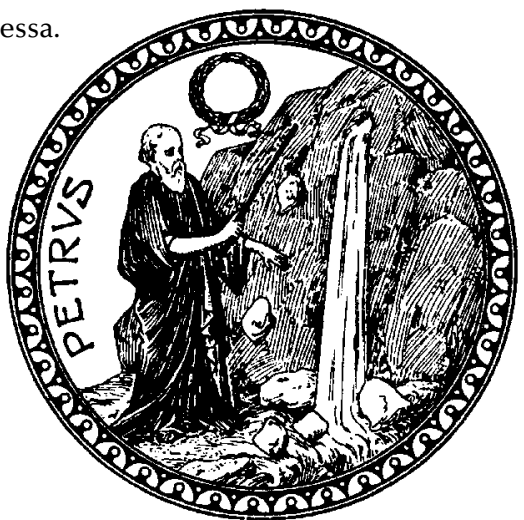

joka muodostaa oman, toisentyyppisen vuodenkierron kirkon piirissä.

Almanakoista voimme lukea, että vuodessa on lisäksi joitakin pyhäpäiviä, jotka eivät sovi kumpaankaan edellämainittuun vuosirytmiin. Ne ovat kaksi rukouspäivää ja itsenäisyyspäivä.

Rukouspäivien juuret ovat 1600-luvulla, jolloin Ruotsi-Suomen kuningas Kustaa Aadolf antoi määräyksen kahden katumus- ja rukouspäivän viettämisestä vuosittain. Luku vakiintui myöhemmin neljäksi.

Yli 300 vuoden ajan valtiovalta antoi vuosittain rukouspäiväjulistuksen, jossa annettiin neljän rukouspäivän päivämäärät ja raamatuntekstit. Kirkko koki rukouspäivät hieman ongelmallisiksi, osittain siksi, että ne syrjäyttivät neljä kirkkovuoden normaalirytmiin kuuluvaa pyhää, osittain siksi, että kirkossa ei oltu järin innokkaita rukoilemaan valtiovallan käskyjen mukaan.

Rukouspäivien asemaa pohdittiin 1900-luvun loppuvuosikymmeninä ja todettiin, että ne ovat säilyttämisen arvoinen perinne. Valmistelukäytäntöä kuitenkin muutettiin eikä rukouspäivistä enää määrää valtiovalta. Kun uusi uskonnonvapauslaki astui voimaan vuonna 2003, Suomen eri kirkkokuntien yhteinen ekumeeninen neuvosto sai tehtäväkseen valmistella vuosittaisen julistuksen rukouspäivien sijoituksesta ja sisällöstä. Presidentti Tarja Halonen lupasi edelleen allekirjoittaa rukouspäiväjulistuksen.

Suomen evankelis-luterilainen kirkko ei ollut uuteenkaan ratkaisuun tyytyväinen, vaan teki kirkolliskokouksessaan 2006 uuden päätöksen asiassa. Sen mukaan rukouspäiväkäytäntöä muutettiin jälleen vuoden 2008 alusta. Rukouspäivien lukumäärä laskettiin kahteen, ja ne ovat 
vastedes kiinteillä päivämäärillä, jotka yleensä sattuvat arkipäiville. Kristittyjen ykseyden rukouspäivä on tammikuun 18. päivänä ja rauhan, ihmisoikeuksien ja kansainvälisen vastuun rukouspäivä on YK:n päivänä lokakuun 24:ntenä.

Itsenäisyypäivämme 6.12. on valtiovallan asettama pyhäpäivä, jolloin kirkoissamme on pidettävä jumalanpalvelus. Kirkko on noudattanut valtion tahtoa, mutta usein jumalanpalvelus on ollut tavallista yksinkertaisempi.

Kalentereista löytyy vielä yksi punaisella merkitty päivä, jota ei tässä luvussa ole aikaisemmin käsitelty: vappu. Vappua ei kirkkokaan sentään tunnusta pyhäpäiväksi, vaikka sen nimi on tullut Valburga-pyhimyksestä. Vappu on kuitenkin nykyään hyvin maallinen merkkipäivä (ks. seuraava luku).

Yliopiston almanakkatoimistossa erehdyttiin eräässä kalenterissa sijoittamaan vappu sellaiseen luetteloon, jossa puhuttiin pyhäpäivistä. Saimme heti vihaisen soiton, jossa ihmeteltiin, millainen pyhä se vappu oikein on. Muutimme kalenterin seuraavassa vuosikerrassa otsikkoon "pyhäpäivien" tilalle sanan "juhlapäiviä".

Kun lakiteksteissä puhutaan juhlapäivistä, täytyy kirkon pyhäpäivien lisäksi mainita vapunpäivä erikseen. Esimerkiksi eräiden verojen maksuista on säädetty, että jos "verojen ja maksujen kanto- tai maksuajan viimeinen päivä tai ennakonpalautusten maksupäivä on pyhäpäivä, vapunpäivä tai arkilauantai, saa maksettavan tai palautettavan erän suorittaa ensimmäisenä arkipäivänä sen jälkeen" (asetus 184/1995).

\section{Ortodoksisen kirkon pyhäpäivät}

Toisen kansankirkkomme ortodoksisen kirkon juhlapäiväkäytäntö eroaa melko paljon evankelis-luterilaisen kirkon käytännöstä. Ortodoksisesta kalenterista löytyy jokaiselta päivältä useita pyhien, marttyyrien ja pyhittäjien nimiä, ja osa pyhäpäivistä on luterilaiselle kirkolle vieraita.

Paastonajoilla on suuri merkitys, kuten katolisessakin kirkossa. Laskiaisesta pääsiäiseen ulottuvan suuren paaston lisäksi ortodokseilla on mm. yli kaksiviikkoinen apostolien paasto kesäkuussa, Herran Äidin paasto elokuussa ennen Marian kuolinpäivää ja joulupaasto marraskuun puolivälistä jouluaattoon. Tärkeimpien paastojen aikana ei ortodoksisessa kirkossa suoriteta esimerkiksi avioliittoon vihkimisiä.
Ortodoksisessa kalenterissa on viitisentoista ns. suurta juhlaa ja suurimpana kaikista pääsiäinen. Suuria juhlia ovat Jeesukseen ja Neitsyt Mariaan liittyvät juhlat, Johannes Kastajan syntymä- ja kuolinpäivä ja Pietarin ja Paavalin päivä.

Vuoden ensimmäinen suuri juhla on loppiainen (6.1.), jonka aiheena on Teofania, Jumalan ilmestyminen, Herran kaste. Kynttilänpäivä on perinteisellä paikalla 2.2. ja sen nimenä on Herran temppeliintuominen.

Myös marianpäivä on vanhalla paikallaan 25.3. ja nimeltään Jumalansynnyttäjän Neitsyt Marian ilmestys. Palmusunnuntaille käytetään nimeä Herran ratsastus Jerusalemiin. Pääsiäispäivä on Suomen ortodoksisessa kirkossa samana viikonloppuna kuin luterilaisessa, vaikka yleensä ortodoksiset kirkot määräävät pääsiäisen vanhan juliaanisen ajanlaskun mukaan.

Helatorstain kohdalla ortodoksisessa kalenterissa lukee Herran taivaaseen astuminen. Molemmat helluntaipäivät, sunnuntai ja maanantai,

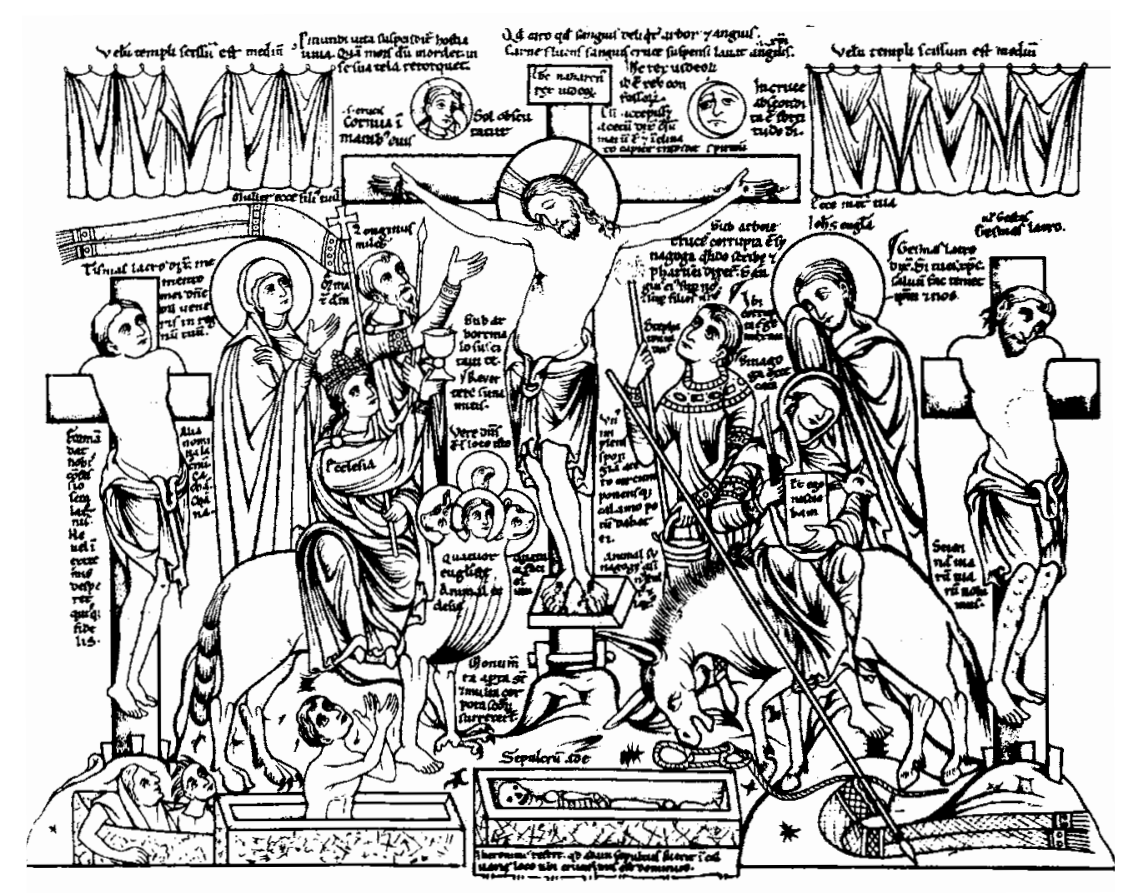

Ortodoksisen kirkon suurin juhla on pääsiäinen. Piirros 1100-luvulta. 


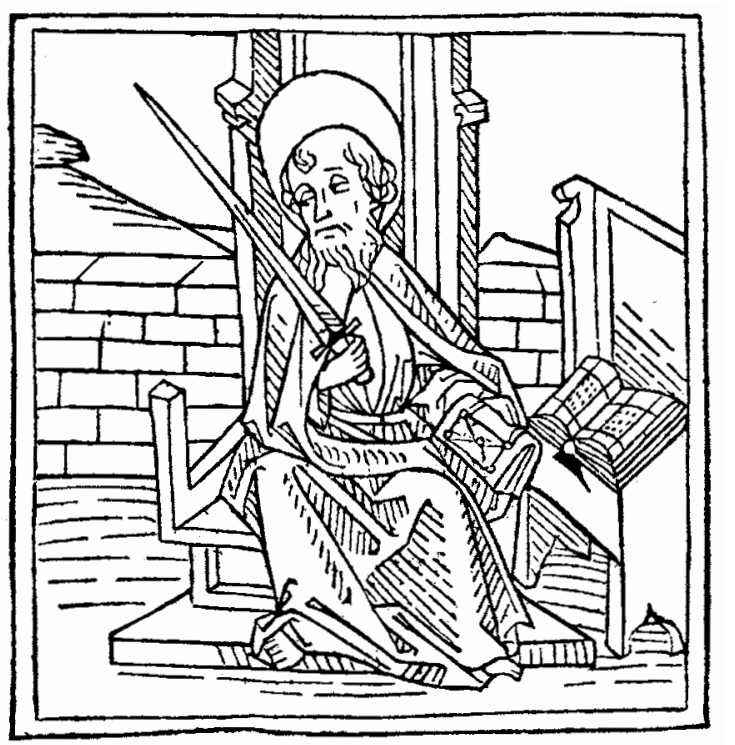

Apostoli Paavali ja hänen tunnusmerkkinsä kirja ja miekka. Piirros saksalaisesta Raamatusta 1400-luvulta.

ovat suuria juhlia: "helluntai, Pyhän Kolminaisuuden juhla" ja "Pyhän Hengen päivä".

Juhannuspäivä on 24.6. ja nimeltään Herran edelläkävijän ja kastajan Johanneksen syntymä. Pietarin ja Paavalin yhteinen päivä on perinteisellä paikallaan 29.6.; apostolit Pietari ja Paavali kuolivat kumpikin tänä päivänä noin vuonna 66-68 jKr. Kuten aiemmin oli puhe, luterilaisessa kirkossa Pietarin ja Paavalin päivä oli pyhäpäivä vuoteen 1772 asti, mutta muutettiin tällöin arkipäiväksi.

Kirkastuspäivä eli ortodoksien "Herran kirkastuminen" on 6.8. Marian kuolinpäivä 15.8. ei Ruotsi-Suomen luterilaisessa kirkossa ole koskaan ollut pyhäpäivä eikä sitä mainita edes uudessa kirkollisessa muistopäiväkalenterissamme. Ortodoksisessa kalenterissa 15.8. on suuri juhla kauniilta nimeltään Jumalansynnyttäjän Neitsyt Marian kuolonuneen nukkuminen.

Johannes Kastajan kuolinpäivä on mainittu luterilaistenkin muistopäivien joukossa. Ortodokseilla 29.8. on suuri juhla, Herran edelläkävijän ja kastajan Johanneksen mestaus. Legendan mukaan Johannes Kastaja mestattiin katkaisemalla hänen kaulansa; siksi vuoteen 1907 asti Suomen almanakassa oli päivän nimenä "Johannes Kastajan kaulan leikkaus".

Luterilainen muistopäiväkalenteri ei tunnusta myöskään Marian syn-
Johannes Kastajan hautaus. Venäläinen ikoni noin vuodelta 1700. (Wikipedia)

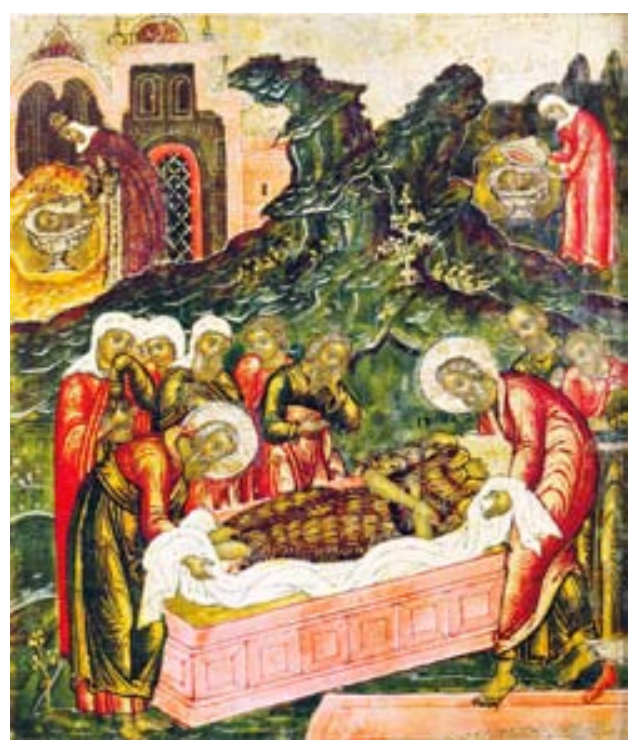

tymää 8.9. Ortodoksien kalenterissa Jumalansynnyttäjän Neitsyt Marian syntymä on suuri juhla.

Syyskuun 14. päivänä juhlitaan "Kunniallisen ja eläväksitekevän Ristin ylentämistä". Kyse on Jeesuksen rististä, joka legendan mukaan löydettiin 300-luvulla tehdyissä kaivauksissa Golgatalta. Ristin päivänä muistetaan Jeesuksen kärsimyksiä.

Myös ortodoksien seuraava juhla on luterilaisessa kirkossa tuntematon. Sitä vietetään lokakuun 1. päivänä ja sanotaan venäläisittäin pokrovaksi tai suomeksi Jumalansynnyttäjän suojelukseksi. Legenda kertoo vanhasta näystä, jossa Neitsyt Maria tuli temppeliin ja levitti säteilevän huntunsa suojelemaan seurakuntaa.

Marraskuun 21. päivänä on Jumalansynnyttäjän Neitsyt Marian temppeliinkäynti. Legendan mukaan Maria vietiin 3-vuotiaana temppeliin ja hän viipyi siellä 11 vuotta.

Viimeinen ortodoksien suurista juhlista on joulu, Kristuksen syntymä.

Ortodoksien suurimmat juhlat luetellaan vuosittain esimerkiksi Yliopiston almanakassa ja Valtiokalenterissa. Täydellistä ortodoksista kalenteria julkaisee Ortodoksisen kirjallisuuden julkaisuneuvosto Kuopiossa. 


\section{KANSALLISET JA KANSAINVÄLISET MERKKIPÄIVÄT}

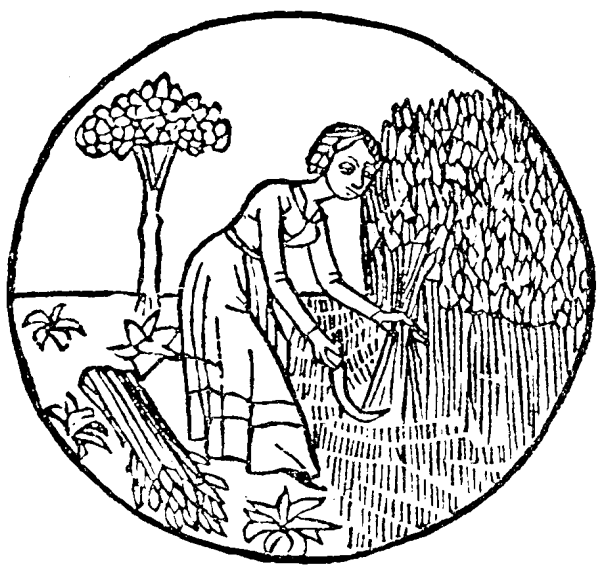

Elokuun askareita Johannes von Gmundenin kalenterissa: Sadonkorjuuta.
$\mathrm{K}$

un Suomi kuului 1700-luvulla Ruotsin vallan alle, oli lmanakassa punaisella värillä merkittynä kulloisenkin kuningasperheen merkkipäiviä, joita myös tavalinen rahvas sai viettää vapaapäivinä. Esimerkiksi 1730-luvulla juhlittiin Fridrikin, Eleonoran ja Ulrican päiviä.

Sama käytäntö jatkui 1800-luvulla, mutta nyt juhlimismääräyksen antajana oli Venäjän tsaari. Niinpä 1800-luvun lopulla ja 1900-luvun alussa kunnioitettiin Aleksein, Mikaelin, Aleksanterin, Marian ja Aleksandran päivää, keisarin ja keisarinnan syntymäpäivää, keisariparin kruunauksen vuosipäivää, leskikeisarinnan ja perintöruhtinaan syntymäpäivää, keisarin valtaistuimelle astumisen vuosipäivää ja jopa keisarillisen perheen pelastumista Borkin rautatieonnettomuudesta.

Kun Keisarillinen Suomen senaatti muuttui Suomen Senaatiksi 1917, sen ensimmäinen päätös lakkautti kaikki keisariin viittaavat juhlat. Juhlakalenteriin jäivät vain kirkolliset pyhäpäivät, ja oman kansallisen merkkipäiväluettelon rakentaminen voitiin aloittaa aivan tyhjästä.

Ensimmäinen uusi juhla oli itsenäisyyspäivä, ja seuraavina vuosikymmeninä kalenteriin alkoi kertyä valtiollisia, kansallisia ja vähitellen myös kansainvälisiä merkkipäiviä. Monet niistä vakiintuivat tai virallistettiin myös liputuspäiviksi.

Vuonna 2013 on Yliopiston almanakassa merkittynä jo kolmattakymmentä maallista merkkipäivää, joista 19 on myös liputuspäiviä. Käymme tässä luvussa läpi kansalliset merkkipäivämme, pohdimme uusia kalenteriin pyrkiviä päiviä ja luomme katsauksen kansanperinteen merkkipäiviin sekä Suomen ainutlaatuiseen nimipäiväkäytäntöön. 


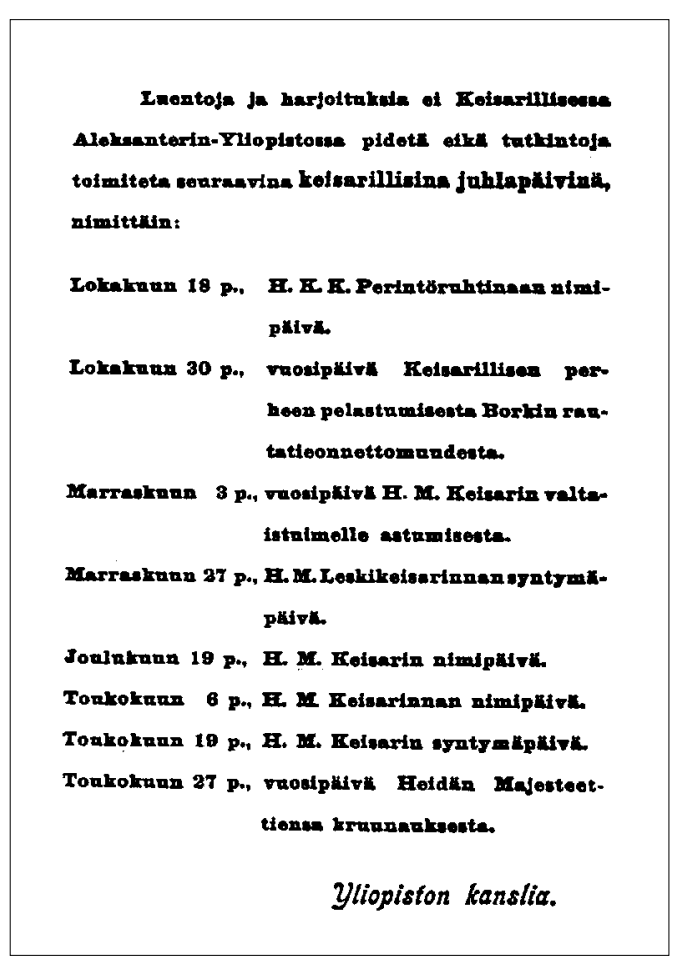

Kuulutus Keisarillisen Aleksanterin Yliopiston (nykyisen Helsingin yliopiston) ilmoitustaululla 1900-luvun alussa. Borkin rautatieonnettomuus sattui 29.10.1888, ja yleensä "Borkin lupa" annettiin 29

lokakuuta. (Piirros Matti Klingen artikkelista Juhlakirjassa)

\section{Tammikuu: Uudenvuodenjuhla ja vainojen uhrit}

Uudenvuodenpäivä on ennen kaikkea maallinen vuodenvaihtumisen juhla, vaikka kirkko onkin pyrkinyt antamaan sille myös uskonnollista sisältöä. Uusivuosi on jokaisen ihmisen elämässä taitekohta, jolloin voi toisaalta katsella taaksepäin ja tehdä tiliä päättyneestä vuodesta, toisaalta tähystellä eteenpäin uutta ja tuntematonta aikaa kohti.

Uusivuosi on myös kansallinen juhlapäivä. Viime vuosisadalla hienoston tapana oli järjestää suuria uudenvuodenkutsuja, ja itsenäisyyden alkuaikoina presidentti järjesti vastaanoton uudenvuodenpäivänä, ei itsenäisyyspäivänä.

Vielä nykyäänkin uuteenvuoteen kuuluu tasavallan presidentin puhe, ja Suomen lippu pöydällä puhujan vieressä välittää juhlatunnelmaa koteihin televisioiden ääreen.

Suomessa uusivuosi ei ole liputuspäivä, toisin kuin esimerkiksi naapu- reissamme Virossa, Ruotsissa ja Norjassa. Uuden tuhatluvun kunniaksi sisäasiainministeriö suositteli Suomalaisuuden Liiton ja Helsingin yliopiston aloitteesta uudenvuodenpäivää liputuspäiväksi vuodeksi 2000, mutta suositus koski vain tätä yhtä vuotta.

Tammikuulle tuli uusi merkkipäivä heti 2000-luvun alussa. Valtioneuvoston kanslia teki helmikuussa 2001 päätöksen uudesta päivästä, joka merkittäisiin kalentereihin. Päivä nimettiin vainojen uhrien muistopäi$v \ddot{a} k s i$, ja silloin muistellaan juutalaisvainojen ja muiden kansanvainojen uhreja. Sen päivämäärä 27. tammikuuta on Auschwitzin keskitysleirin vapautuksen päivä.

Valtioneuvoston kanslian tiedote totesi: "Päivä muistuttaa meitä yli 50 vuoden takaisista tapahtumista, joiden kukaan ei soisi toistuvan ihmiskunnan historiassa. Ihmisen muisti on kuitenkin rajallinen. Sen vuoksi noista vuosikymmenten takaisista tapahtumista tulee kertoa. Nuorisolla on oltava riittävästi tietoa, jotta ihmisarvoa ja suvaitsevaisuutta ei unohdeta."

Vainojen uhrien muistopäivän viettämisestä on antanut pätöslauselman Euroopan parlamentti ja sitä vietetään Suomen lisäksi esim. Saksan liittotasavallassa, Britanniassa, Italiassa, Ruotsissa ja Tanskassa.

Päivä on merkitty kalentereihin vuodesta 2002 alkaen. Päivä ei ole liputuspäivä.

\section{Helmikuu: Runeberg ja saamelaiset}

Helmikuussa on almanakassa neljä erikoispäivää. Kansallisrunoilijamme Johan Ludvig Runeberg (1804-77) on saanut oman merkkipäivän helmikuun 5:nnelle, syntymäpäivälleen. Runebergin päivän vietto aloitettiin jo Venäjän vallan aikana. Kun keisari kielsi Runebergin juhlinnan kulkueilla ja lipuilla, kansa poltti päivän kunniaksi kynttilöitä kotien ikkunoilla.

Itsenäisyyden alkuaikoina Runebergin päivä oli ennen kaikkea ruotsinkielisen väestön juhla (ja Kalevalan päivä suomalaisen), mutta nykyään Runebergia juhlitaan tasapuolisesti niin suomen- kuin ruotsinkielistenkin piirissä. Nuorimmaiset tuntevat Runebergin ainakin makeista Runebergin tortuista ja liehuvista lipuista. Runebergin päivä kuuluu vakiintuneisiin liputuspäiviin, ja se on ollut Yliopiston almanakan liputuspäivälistassa vuodesta 1952 lähtien. 
Runebergin patsas

Helsingissä Esplanadin

puiston keskellä. Merkkimiehelle on pystytetty patsas myös Porvoo-

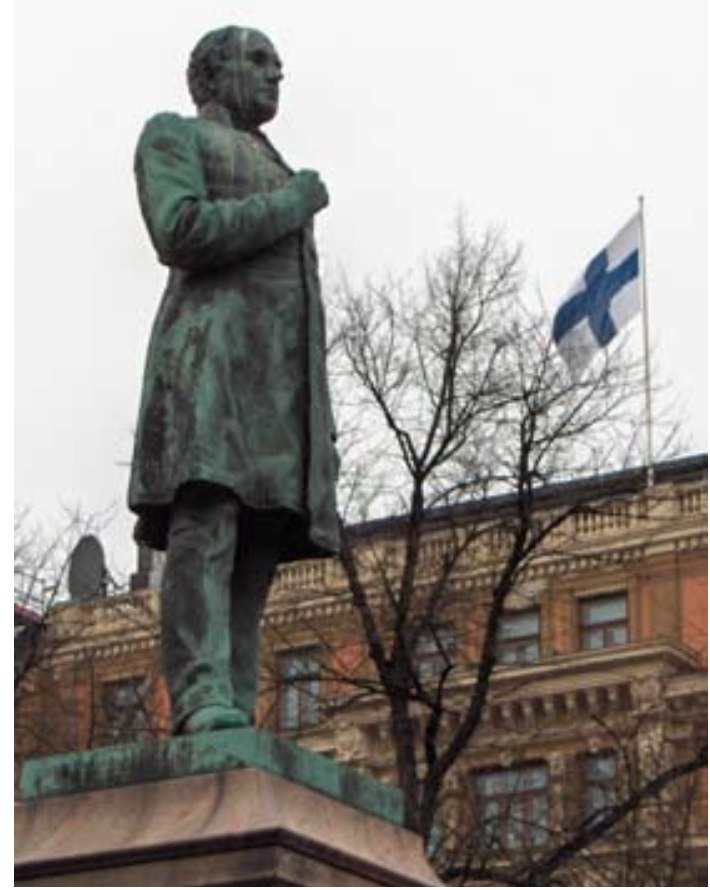

Saamelaisten kansallispäivä otettiin kalentereihin vuodesta 2004 alkaen. Juhlaa vietetään helmikuun 6. päivänä, heti Runebergin päivän jälkeen.

Saamelaiset ovat Euroopan unionin alueen ainoa alkuperäiskansa. Omaa kansallispäivää saamelaiset ovat viettäneet 1990-luvulta alkaen. Ehdotuksen kansallispäivän merkitsemisestä almanakkoihin teki Oulun yliopiston rehtori Lauri Lajunen.

Päivämäärä 6.2. on peräisin vuodelta 1917 , jolloin Norjan ja Ruotsin saamelaiset pitivät Trondheimissa ensimmäisen yhteisen kokouksen. Suurimpana huolena oli saamelaisten elinmahdollisuuksien säilyminen, koska pääväestö otti käyttöönsä yhä enemmän saamelaisten maita.

Saamelaisten kansallispäivä oli Pohjoismaiden saamelaisten ensimmäinen virallisluonteinen liputuspäivä. Oman lipun saamelaiset saivat 1986. Nykyään maamme saamelaisilla on yksitoista omaa liputuspäivää (ks. s. 207).

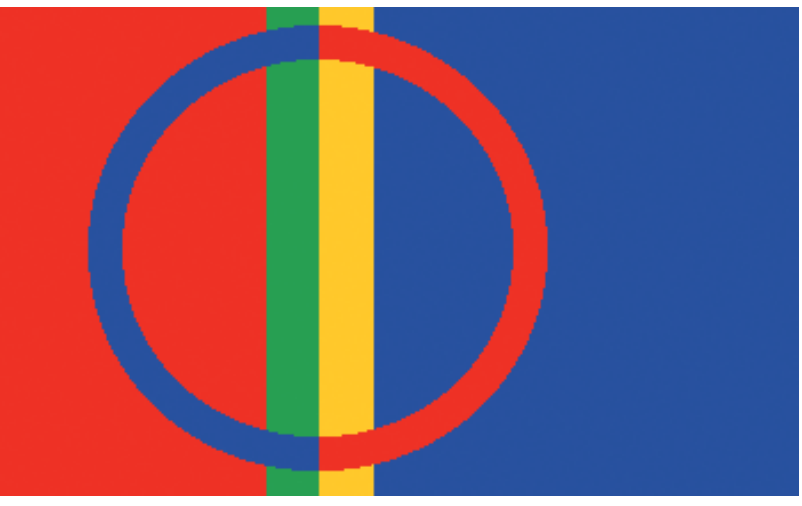

Saamelaisten ensimmäinen liputuspäivä oli heidän kansallispäivänsä 6.2 .

Vaikka saamelaisten kansallispäivä on saamelaisten liputuspäivä, sitä ei merkitä almanakkoihin suomalaiseksi liputuspäiväksi.

\section{Helmikuu: Valentinus ja Lönnrot}

Ystävänpäivän (14.2.) juuret ovat vanhassa Roomassa, jossa helmikuun puolivälissä vietettiin keväistä hedelmällisyysjuhlaa, lupercaliaa. Kristillisessä kirkossa sattui samoille päiville marttyyri Valentinuksen päivä, ja monet roomalaisen lemmenjuhlan tavat siirtyivät Valentinin päivälle. Etelä-Euroopassa arvaillaan vieläkin, että linnut valitsevat itselleen parin juuri Valentinuksen päivänä. Jos on kiinnostunut alkuperäisestä Valentinus-marttyyristä, voi lukea häntä koskevat legendat katolisen kirkon pyhimysluettelosta http://www.catholic.org/saints/.

Kansainvälistyvät tavat toivat Valentinin päivän Suomeen 1980-luvulla, jolloin päivää ruvettiin rummuttamaan pikkurihkaman ostopäivänä ja tervehdyskorttien lähetyspäivänä. Sydäntervehdysten tai suklaanamujen antaminen on nopeasti yleistynyt varsinkin koululaisten kesken, ja päiväkodeissa vietetään iloisia ystävänpäivänjuhlia.

Yliopiston almanakkaan ystävänpäivä merkittiin kustantajanvaihdoksen yhteydessä puolivahingossa 1990-91 ilman yliopiston virallista päätöstä, mutta vuodesta 1996 sillä on jo yliopistonkin siunaus takanaan: päivä on tullut meille jäädäkseen.

Kalevalan päivän ajankohta 28.2. on saatu siitä päivämäärästä, jolloin Elias Lönnrot allekirjoitti Suomen kansalliseepoksen Kalevalan ensimmäisen painoksen esipuheen vuonna 1835. Yliopiston savokarjalainen 
osakunta otti päivän vuosipäiväkseen kolmekymmentä vuotta myöhemmin, ja Kalevalan 50- ja 75-vuotisjuhlia vietettiin näyttävästi.

Yleiseksi liputuspäiväksi Kalevalan päivä alkoi vakiintua 1920-luvulla, ja almanakassa on päivä merkitty liputuspäiväluetteloon vuodesta 1952 alkaen. Vuoden 1978 uudessa lippuasetuksessa Kalevalan päivä on virallinen liputuspäivä. Se sai samalla toisen määreen "suomalaisen kulttuurin päivä".

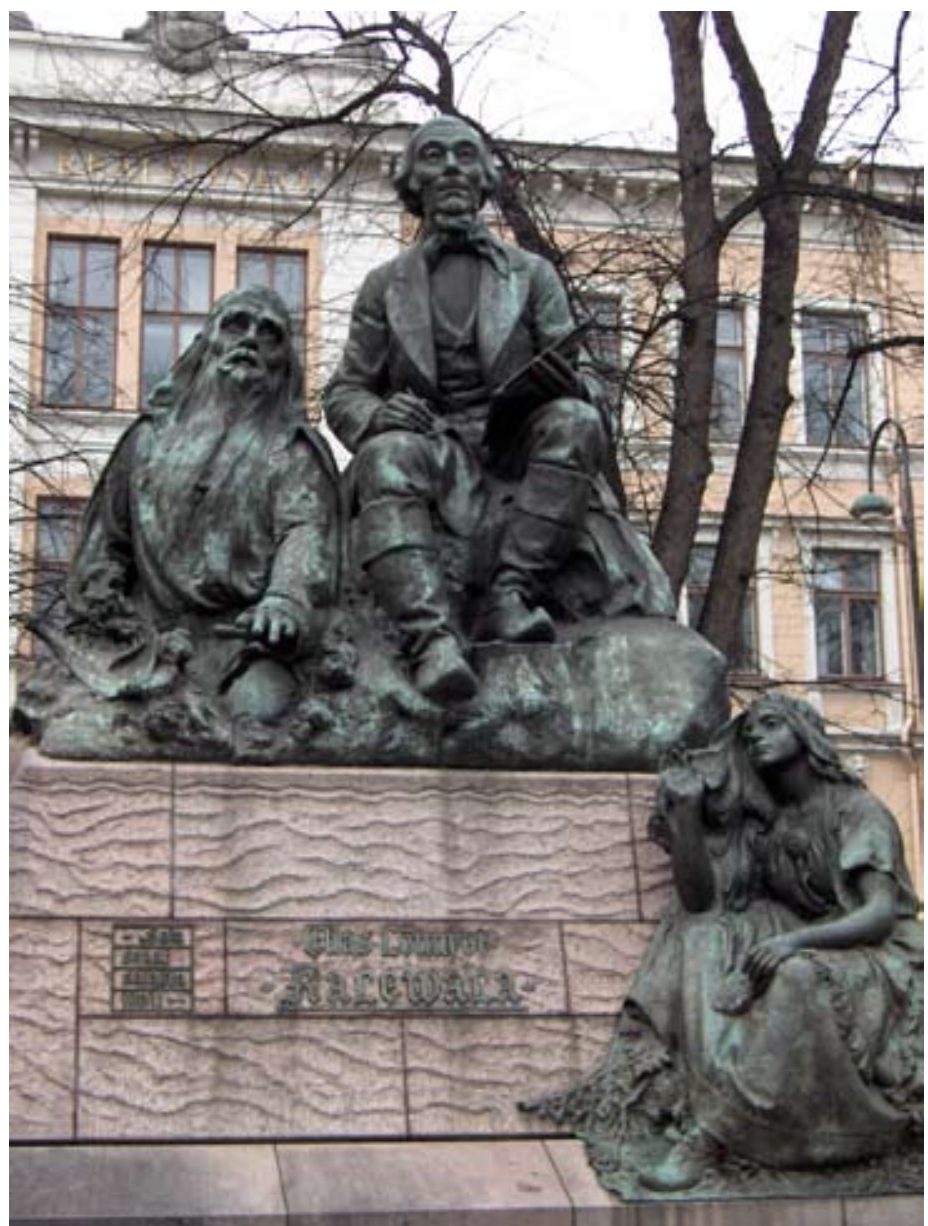

Elias Lönnrotille pystytetty patsas Helsingissä Lönnrotinkadun varrella. Lönnrotilla on patsas lisäksi ainakin Kajaanissa, Nurmeksessa ja Sammatissa.

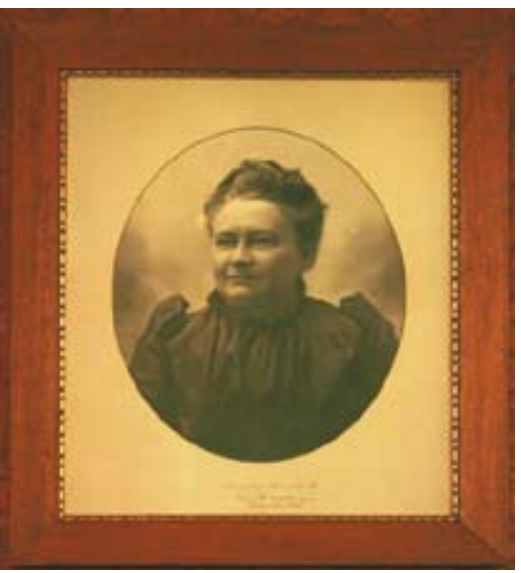

Minna Canth (1844-1897) sai oman liputuspäivän kalentereihin vuosikerrasta 2007 alkaen

\section{Maaliskuu: Naistenpäivä ja Minna Canth}

Kansainvälinen naistenpäivä maaliskuun 8:ntena on syntynyt samoina aikoina kuin äitienpäivä eli 1910-luvulla, mutta poikkeaa siitä suuresti luonteeltaan. Kun äitienpäivä on porvarillinen perhejuhla, oli naistenpäivä pitkään vasemmistolainen mielenosoituspäivä. Naiset hakivat tämän päivän avulla tasa-arvoa ja äänioikeutta.

Vuodesta 1945 alkaen YK on tukenut naistenpäivän viettoa kaikkialla maailmassa. Itä-Euroopan maissa naistenpäivä on muodostunut yleiseksi vapaapäiväksi, mutta Suomessa sen vietto on ollut vähäisempää. Meilläkin naistenpäivän merkitys kasvoi 1980-luvulla, ja päivää alettiin viettää muutoinkin kuin vasemmiston piirissä. Naistenpäivä pääsi Yliopiston almanakkaan vahingossa 1990-91, mutta vuodesta 1994 alkaen se otettiin yliopiston päätöksellä uudelleen mukaan.

Helsingin yliopisto teki lokakuussa 2005 päätöksen, että Minna Canthin päivä 19.3. merkitään vuodesta 2007 alkaen kalentereihin liputuspäiväksi.

Esitys uudesta liputuspäivästä tuli sisäasiainministeriöltä, joka oli jo kolmena vuonna määrännyt valtion virastot ja laitokset liputtamaan maaliskuun 19. päivänä Minna Canthin syntymäpäivän ja tasa-arvon kunniaksi.

Koska liputuksesta oli saatu myönteistä palautetta, sisäministeriö teki Helsingin yliopiston almanakkatoimistolle ehdotuksen, että päivä merkittäisiin kalentereihin. Almanakkatoimiston mielestä Minna Canthin 
päivä sopii hyvin almanakan muiden merkkipäivien joukkoon. Almanakkatoimisto oli yhteydessä myös Suomalaisuuden liittoon, joka huolehtii suomalaisesta liputuskäytännöstä. Suomalaisuuden liitolla ei ollut mitään Minna Canthin päivän merkitsemistä vastaan.

Niinpä Helsingin yliopiston rehtori allekirjoitti päätöksen, että Minna Canthin päivä merkitään liputuspäiväksi yliopiston almanakkaan vuosikerrasta 2007 alkaen. Uuden liputuspäivän virallisena nimenä on Minna Canthin päivä, tasa-arvon päivä.

Minna Canthin päivän liputuksesta ovat iloinneet varsinkin naisasiapiirit, sillä Suomessa on aikaisemmin liputettu vain miesten kunniaksi.

\section{Huhtikuu: Romaneista veteraaneihin}

Huhtikuulle sattuu kalenteriemme uusin merkkipäivä, romanien kansallispäivä. Se merkitään kalentereihin vuosikerrasta 2014 alkaen. Sen päivämäärä 8.4. on saatu vuodelta 1971, jolloin Lontoossa pidettiin ensimmäinen kansainvälinen romanikongressi ja hyväksyttiin romanien oma lippu.

"Romanit ovat vakiintunut vähemmistö Suomessa ja romanikulttuuri on ollut tärkeä osa suomalaista kansankulttuuria satojen vuosien ajan", toteaa kansatieteen professori Hanna Snellman Helsingin yliopistosta.

Valtakunnallinen romaniasiain neuvottelukunta teki ensimmäisen ehdotuksen romanien kansallispäivän saamiseksi kalentereihin vuonna 2001. Tuolloin Helsingin yliopistossa katsottiin, ettei aika ollut vielä kypsä. Vantaan paikallisromanityöryhmä teki syksyllä 2011 uuden ehdotuksen, ja nyt ehdotus hyväksyttiin. Päivä ei ole Suomessa liputuspäivä.

Mikael Agricolan päivää (9. huhtikuuta) vietetään suomalaisen kirjallisuuden isän, Agricolan (n. 1510-1557) kuolinpäivänä. Agricolan tekemä ABCkiria vuodelta 1542 oli ensimmäinen suomeksi painettu kirja. Agricola käänsi suomen kielelle myös uuden testamentin.

Mikael Agricolan päivää ehdotti almanakkaan Agricola-seura vuonna 1958. Helsingin yliopisto hyväksyi ehdotuksen, ja vuodesta 1960 lähtien päivä on merkitty kalentereihin. Vuodesta 1980 alkaen päivän kohdalla on ollut lipun kuva, koska se on katsottu vakiintuneeksi liputuspäiväksi.

Nykyään Agricolan päivällä on lisämääre suomen kielen päivä. Osa kielemme kehittämisen kunniasta kuuluu myös Elias Lönnrotille, joka

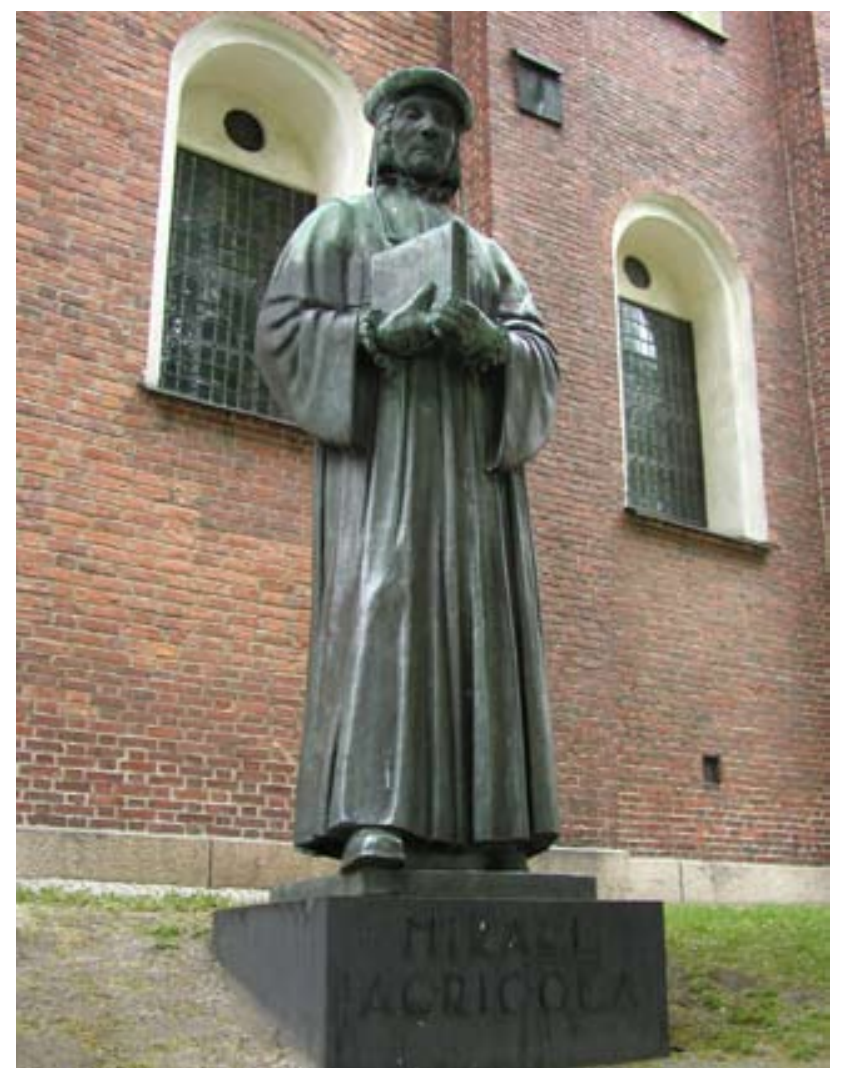

Mikael Agricolan patsas Turun tuomiokirkon edustalla. (Kuva Turun ja

Kaarinan seurakuntayhtymä.)

on syntynyt samana päivänä, 9. huhtikuuta (vuonna 1802). Päivä valittiin Eljaksen nimipäiväksi jo 1927.

Kansallista veteraanipäivää on Suomessa juhlittu vuodesta 1987 alkaen, ja almanakassa päivä oli ensimmäisen kerran 1988. Veteraanipäivän idea lähti meillä sosiaalidemokraattisesta puolueesta, ja pääpuuhamiehenä oli silloinen pääministeri Kalevi Sorsa.

Veteraanipäivän mallia on otettu mm. Yhdysvalloista, jossa ensimmäisen maailmansodan loppumispäivää (11.11.) vietetään Veterans' Dayna. Suomalaisen veteraanipäivän päivämääräksi valittiin meikäläisittäin merkittävä sodanloppumispäivä. Huhtikuun 27:ntenä 1945 päättyi Lapin sota, ja viimeiset saksalaiset joukot poistuivat maastamme.

Valtioneuvosto määräsi 1980-luvun lopulla veteraanipäivän myös yleiseksi liputuspäiväksi. Veteraanipäivänä kunnioitetaan vielä elossa olevia 
sotaveteraaneja; heitä oli 1980-luvulla vielä runsaat 300 000. Veteraanipäivän idea on hieman toinen kuin sodassa kuolleiden muistopäivän, jota vietään toukokuussa (ks. kaatuneitten muistopäivä).

\section{Toukokuu: Vapusta äitienpäivään}

Vapunpäivä (1.5.) ei ole nykyään kirkkopyhä, vaikka sitä on Suomessa vietetty jo keskiajalla abbedissa Valburgin pyhimykseksi julistamispäivänä. Vappu on nykyään suomalaisen työn päivä, jota juhlivat työläiset ja myös ylioppilaat. Vapunvieton taustalla ovat vanhat keskieurooppalaiset kevätjuhlat. Talvi on takana ja kesä on alkanut. Valpurinyö oli Saksassa tunnettu myös noitien ja taikuuden yönä.

Vapun vietto levisi Ruotsin kautta Suomen ylioppilaiden piiriin 1800luvulla. Aluksi suomalaiset pitivät kevätjuhliaan pari viikkoa myöhemmin, Kukan eli Flooran päivän tienoilla, jolloin meilläkin kesä alkaa olla voitolla. Mutta eurooppalainen käytäntö voitti jo 1800-luvun lopulla, ja sen jälkeen ylioppilaat ovat pitäneet kevätkarnevaalinsa vappuna ja sen aattona.

Työläisten vappuperinne on hieman nuorempaa kuin ylioppilaiden. Yhdysvalloissa 1.5. oli työsopimusten loppumispäivä, jolloin solmittiin uudet sopimukset tai siirryttiin uusiin työpaikkoihin. Se sopi hyvin myös mielenosoitusten ja poliittisten marssien päiväksi.

Vappu määrättiin Suomessa vuoden 1978 liputusasetuksessa yleiseksi liputuspäiväksi ja se sai lisämääreen suomalaisen työn päivä.

Vuoden 2003 kalenteriin lisättiin uutuutena Eurooppa-päivä 9. toukokuuta. Ehdotus Eurooppa-päivän merkitsemisestä tuli Eurooppalainen

Euroopan unionin lipussa on sinisellä pohjalla 12 tähteä.

Lipun voi nostaa liehumaan esimerkiksi EU-vieraiden kunniaksi.

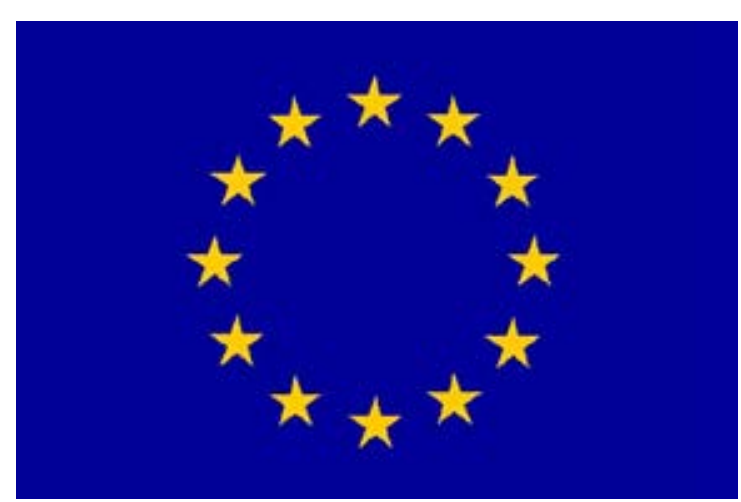

Suomi ry:ltä. Yhdistys totesi ehdotuksessaan, että Eurooppa-päivää on vietetty Suomessa jo seitsemänä vuonna. Suositus päivän viettämisestä on tehty Milanon huippukokouksessa vuonna 1985.

Päivämäärä 9. toukokuuta on saatu vuodelta 1950, jolloin lausuttiin nykyisen Euroopan unionin syntysanat. Tuolloin Ranskan ulkoministeri Robert Schuman antoi julistuksen, jossa "Ranskan hallitus ehdottaa koko Ranskan ja Saksan hiili- ja terästuotannon asettamista yhteisen korkean viranomaisen alaisuuteen, järjestöön, joka on avoin muidenkin Euroopan maiden osallistumiselle."

Liputuspäivä Eurooppa-päivästä tuli vuodesta 2011 alkaen. Sisäministeriö oli vuodesta 1998 lähtien suositellut kertaluonteista liputusta Eurooppa-päivänä kaikkina niinä vuosina, jolloin päivä ei ole sattunut äitienpäivälle. Helsingin yliopisto päätti ottaa vuodesta 2011 alkaen päivän mukaan liputuspäiväluetteloonsa.

Äitienpäivää vietetään toukokuun toisena sunnuntaina. Päivän "äitinä" oli amerikkalainen Ann Jarvis, joka halusi järjestää kaikille äideille omistetun juhlapäivän koko maahan. Jo vuonna 1914 äitienpäivä tuli Yhdysvalloissa viralliseksi liputuspäiväksi.

Suomessa äitienpäivää ruvettiin viettämään 1910-luvulla, ja 1920luvun lopulla sen paikaksi vakiintui meilläkin toukokuun toinen sunnuntai. Esimerkiksi Ruotsissa päivää vietetään toukokuun viimeisenä sunnuntaina.

Viralliseksi liputuspäiväksi äitienpäivä tuli meillä vuonna 1947, ja vuodesta 1950 alkaen se on ollut merkittynä Yliopiston almanakkaan.

Äitienpäivä on vakiintunut Suomeen koko kansan perhejuhlaksi, jota juhlistetaan niin päiväkodeissa äitienpäiväkortteja näperrellen kuin presidentin linnassa, jossa jaetaan äideille ansiomerkkejä.

\section{Toukokuu: Snellmanista sankarivainajiin}

Johan Vilhelm Snellmania on sanottu suomalaisuuden isäksi. Snellmanin syntymäpäivää 12.5. vietettiin näyttävästi jo 1800-luvulla. Snellman oli syntynyt 1806, ja hän kuoli pari kuukautta 75-vuotisjuhliensa jälkeen 1881.

Suuri juhla pidettiin Snellmanin syntymän satavuotispäivänä 1906, jolloin Suomi vielä kuului Venäjälle. Kansallisuushenki oli korkealla, ja juhlassa mm. perustettiin Suomalaisuuden Liitto. 
Johan

Vilhelm

Snellmanin

patsas Hel-

singissä

Suomen

Pankin edus-

talla.

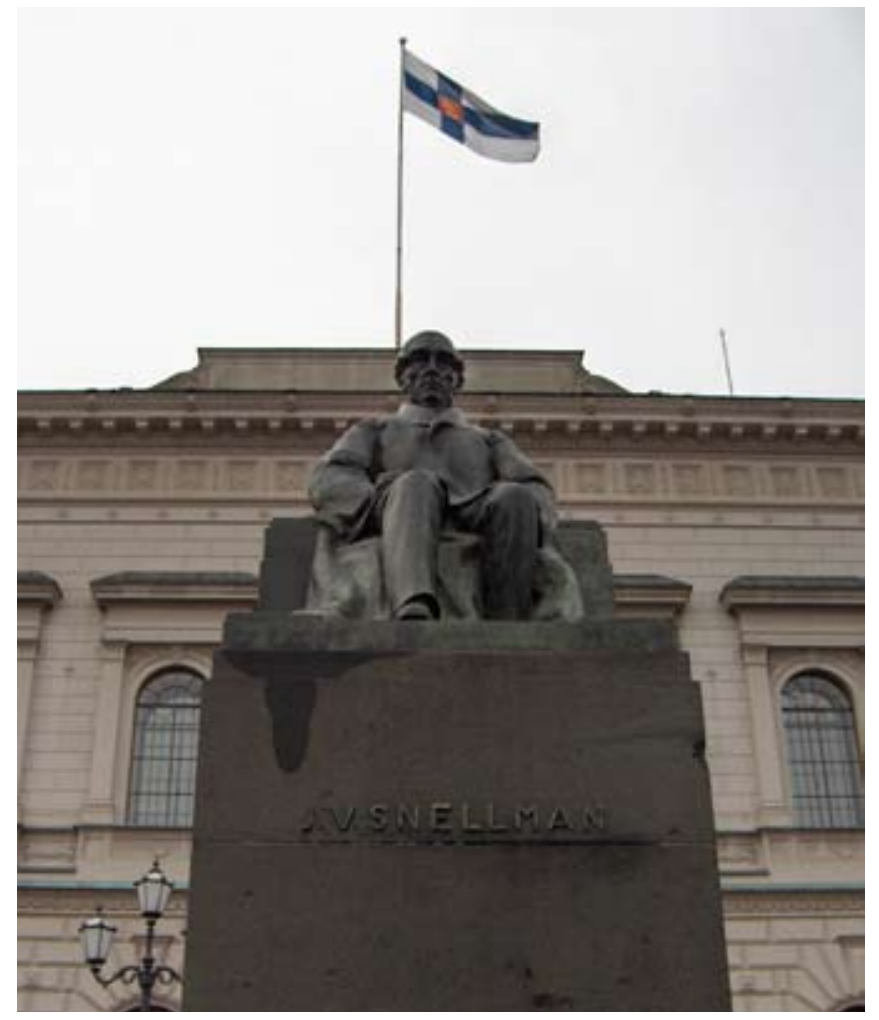

Snellmanin päivää suositeltiin yleiseksi liputuspäiväksi jo 1920-luvulla, ja almanakan liputuspäiväluetteloon otettiin toukokuun 12. päivä 1952. Vuodesta 1978 alkaen Snellmanin päivällä on ollut lisämääre suomalaisuuden päivä.

Nykyajan aikuiset muistavat Snellmanin ehkä parhaiten vanhasta sadan markan setelistä, jossa oli vuoteen 1986 asti Snellmanin kuva.

Kaatuneitten muistopäivä toukokuun kolmantena sunnuntaina sai alkunsa vuonna 1940, kohta talvisodan jälkeen. Edellisinä vuosikymmeninä, 1920- ja 30-luvulla, oli toukokuussa vietetty näyttävästi vapaussodan päätöspäivää 16.5., jolloin valkoiset joukot marssivat Helsinkiin Mannerheimin johdolla (vuonna 1918).

Talvisodan jälkeen katsottiin, että vapaussodan voittopäivän juhliminen ei enää ollut mielekästä. Piispainkokouksen aloitteen pohjalta marsalkka Mannerheim määräsi, että toukokuun 16. päivän sijaan oli

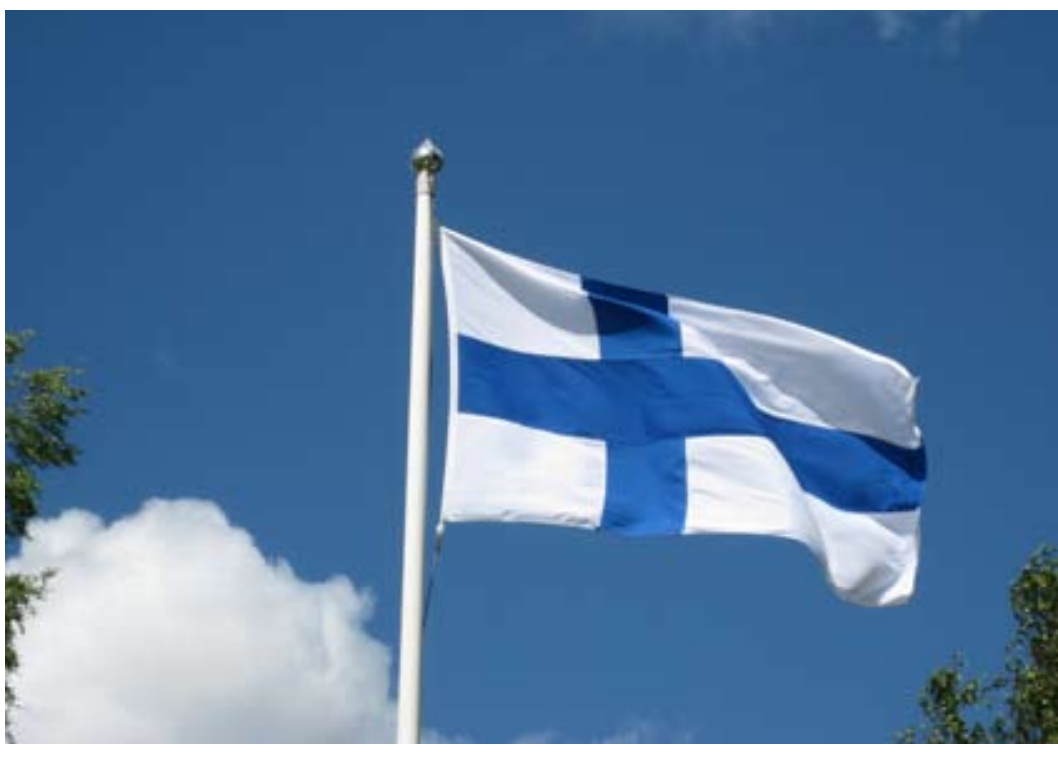

Juhannus on Suomen lipun päivä. (Kuva Arja Latvala)

toukokuun kolmatta sunnuntaita vietettävä "nyt päättyneessä sodassa kaatuneiden sankarivainajien sekä myös kaikkien murroskautena 1918 molemmin puolin vakaumuksensa puolesta henkensä uhranneiden yhteisenä uskonnollisena muistopäivänä".

Päivän nimi oli aluksi sankarivainajien muistopäivä, mutta vuodesta 1946 alkaen sitä on kutsuttu kaatuneitten muistopäiväksi. Vuoteen 1994 asti pidettiin osan päivää lippu surun merkiksi puolitangossa, mutta sen jälkeen kaatuneitten muistopäivänäkin on ollut normaali liputus.

\section{Kesäkuu: Lipun juhlaa armeijassa ja kokon ääressä}

Edellä mainittu valkoisten paraatin päivä 16.5. oli itsenäisyytemme alkuvuosikymmeninä armeijan lippujuhlan päivä. Vuonna 1942, Mannerheimin täyttäessä 75 vuotta, siirrettiin lippujuhla marsalkan syntymäpäivälle 4.6. Näin valkoisten voittojuhla katosi kokonaan juhlakalentereistamme.

Aluksi kesäkuun 4. päivää kutsuttiin Suomen Marsalkan syntymäpäiväksi, mutta kun päivä tuli mukaan Yliopiston almanakkaan 1950, sillä 
oli jo nimenä puolustusvoimain lippujubla. Vuoden 1978 liputusasetus mainitsee puolustusvoimain lippujuhlan päivän virallisena liputuspäivänä. Jollakin Suomen paikkakunnalla pidetään nykyäänkin näyttävä sotilasparaati, ja presidentti jakaa ylennyksiä ja kunniamerkkejä puolustusvoimain piirissä.

Juhannus on vanha keskikesän juhla, jota on vietetty vuoden valoisimman ajan kunniaksi. Päivä on juhannuksen alla pisimmillään. Vaikka kirkko on pyrkinyt antamaan juhannukselle uskonnollista sisältöä, se on uudenvuoden tapaan ennen kaikkea maallinen juhla.

Juhannus on Suomen laajimmin juhlittu karnevaali. Se ei ole yhtä suuri kalenterin taitekohta kuin uusivuosi, mutta kesän lämmin luonto antaa koko kansalle mahdollisuuden viettää juhlaa ulkona kokkotulien ja tanssilavojen äärellä.

Kuten edellisessä luvussa todettiin, juhannus oli vuoteen 1954 asti kiinteällä paikalla 24.6., mutta vuodesta 1955 alkaen se on ollut 20. ja 26.6. välille sattuvana lauantaina.

Juhannus valittiin 1920-luvulla Suomen lipun päiväksi, ja nykyään lippua pidetään liehumassa yhtä mittaa perjantai-illasta lauantai-iltaan asti.

\section{Heinäkuu: Eino Leino ja unikeko}

Heinäkuulle sattuu kaksi maallisista merkkipäivää, Eino Leinon päivä ja unikeonpäivä.

Helsingin yliopisto hyväksyi almanakkaansa Eino Leinon päivän vuonna 1997, ja ensimmäisen kerran se näkyi vuoden 1998 almanakoissa. Eino Leinon päivää eli runon ja suven päivää juhlitaan heinäkuun 6: ntena. Se on myös liputuspäivä.

Suomalaisuuden liitto oli maininnut Eino Leinon päivän omassa liputuspäiväluettelossaan jo parin vuoden ajan. Helsingin yliopisto teki päätöksensä Eino Leinon päivän ottamisesta almanakkaan kokkolalaisen kirjallisuudenystävän Elvi Löhösen aloitteesta.

Ennen päätöstään yliopisto pyysi lausunnon asiasta assistentti Sirpa Karjalaiselta Helsingin yliopiston kansatieteen laitoksesta. Karjalainen totesi, että Eino Leinon syntymäpäivän eli heinäkuun kuudennen vietto on vuodesta 1992 alkaen kasvattanut nopeasti suosiotaan.

Eino Leinon (1878-1926) päivä ajoittuu heinäkuun alkupuolelle,

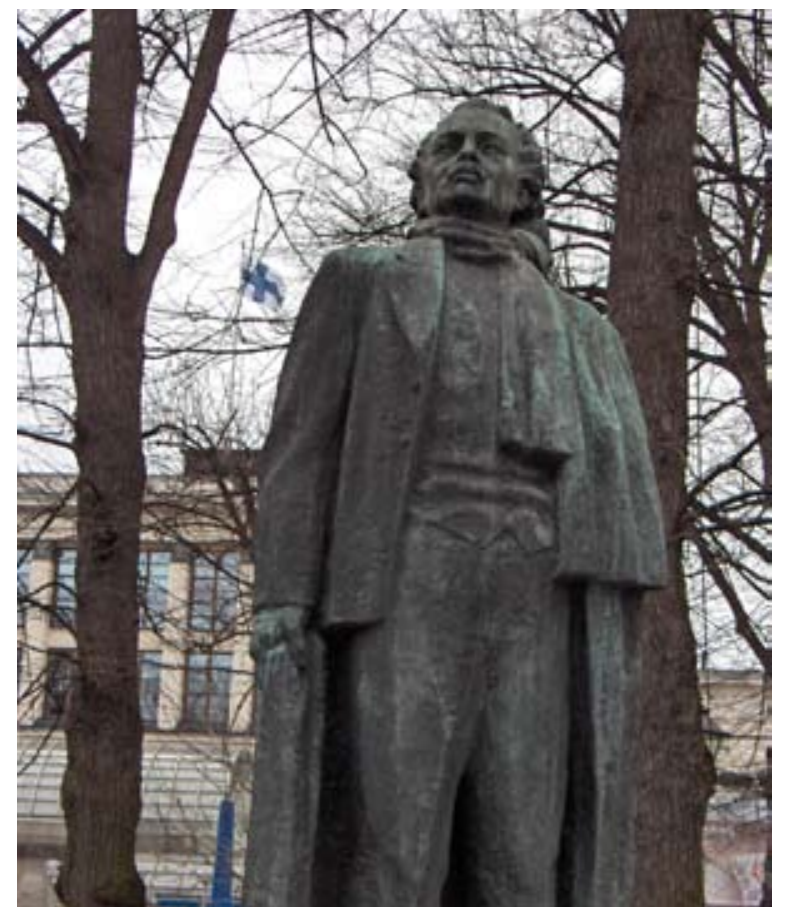

Eino Leinon patsas Helsingissä Esplanadin puistossa Patsaan jalustaan on kaiverrettu säkeet: "Yksi on laulu ylitse muiden, ihmisen aattehen, hengen ankara laulu."

ajankohtaan, joka muutoin on merkkipäiväkalenterissa hiljaista kautta. Heinäkuinen Eino Leinon päivä täyttää merkkipäivätyhioiötä. Päivälle annettu lisämäärite "runon ja suven päivä" sopii sekin ajankohtaan, arvioi Karjalainen.

Unikeonpäivä on muissa kielissä nimeltään "seitsemän nukkujan päivä". Legenda kertoo, että Efesossa seitsemän kristittyä nuorukaista pakeni 200-luvulla keisari Deciuksen vainoja erääseen luolaan. Nuorukaiset nukahtivat ja nukkuivat luolassa lähes kaksisataa vuotta, ennen kuin tulivat taas päivänvaloon. Legenda tietää nuorukaisten nimetkin: Johannes, Constantinus, Maximianus, Malchus, Martianus, Dionysius ja Serapion. Heidät julistettiin kuolemansa jälkeen pyhimyksiksi.

Suomesssa unikeonpäivä on ollut merkittynä jo ensimmäisiin suomalaiskalentereihin (1705). Päivä on saanut meillä uutta sisältöä, kun nykyään Naantalissa valitaan iloisissa aamujuhlissa valtakunnallinen unikeko ja jokaisessa perheessä voidaan pisimpään nukkuja nimetä unikeoksi.

Unikeon päivämäärään liittyy pieni erikoisuus. Suomen, Ruotsin ja 
Norjan kalentereissa päivä on heinäkuun 27:s, mutta esimerkiksi Tanskan, Viron ja Englannin kalentereissa se on merkitty kuukautta aikaisemmaksi, kesäkuun 27:nneksi. Kesäkuun lopulla unikeko oli myös ensimmäisissä suomalaisissa almanakoissa 1700-luvun alussa, mutta 1720-luvulta lähtien päivämäärä on aina ollut 27.7.

\section{Syyskuu: Yrittäjän päivä}

Viimeisimmän nimipäiväuudistuksen yhteydessä Helsingin yliopisto päätti ottaa almanakkaan uuden merkkipäivän, yrittäjän päivän, vuosikerrasta 2010 alkaen. Sitä vietetään vuosittain syyskuun 5. päivänä. Päivä ei ole liputuspäivä.

Yrittäjän päivää on vietetty Suomessa 1990-luvulta lähtien, ja päivän vietto on laajentunut valtakunnalliseksi tapahtumaksi. Yritykset järjestävät esimerkiksi avoimien ovien päiviä tai kutsuvat opettajia ja oppilaita tutustumaan toimintaansa.

Aloitteen uudesta merkkipäivästä teki toimitusjohtaja Riitta Antinmäki Yrittäjän päivä -säätiöstä jo 2000-luvun alussa. Vuonna 2008 Helsingin yliopisto katsoi, että päivä on kyllin vakiintunut, ja päätti merkitä päivän almanakkaan. Yrittäjän päivä -säätiö neuvottelee parhaillaan yrittäjän päivän saamiseksi merkkipäiväksi koko EU:n alueella.

\section{Lokakuu: Aleksis Kivi ja Yhdistyneet kansakunnat}

Uusmaalainen kirjailija Aleksis Kivi syntyi 10.10.1834 ja kuoli 31.12.1872 vain 38-vuotiaana. Lähes kaikille suomalaisille ovat tuttuja hänen kirjoittamansa Seitsemän veljestä ja Nummisuutarit.

Aleksis Kivi loi suomalaisen näytelmä- ja romaanikirjallisuuden. Kun 1900-luvun alkupuolella haluttiin kohottaa näkyviin kansallisia kulttuurihahmoja, oli Kivi luonnollinen valinta. Hänen kuolemansa 50-vuotispäivää vietettiin näyttävästi 1932, syntymänsä satavuotispäivänä hän sai patsaan Nurmijärvelle ja viisi vuotta myöhemmin, 1939, tunnetun patsaansa Helsingin Rautatientorille.

Suomalaisuuden liitto harkitsi Kiven syntymäpäivää 10.10. liputuspäiväksi jo 1920-luvulla, ja vuodesta 1952 alkaen päivä on merkitty almanakan liputuspäiväluetteloon. Vuoden 1978 liputusasetuksessa Aleksis Kiven päivälle annettiin lisämääre suomalaisen kirjallisuuden päivä.
Yhdistyneiden kansakuntien eli YK:n perustamispäivänä pidetään lokakuun 24. päivää vuonna 1945, jolloin riittävä määrä jäsenvaltioita oli hyväksynyt perustamisasiakirjan. Suomen YK-liitto ehdotti Helsingin yliopistolle 1966, että päivä otettaisiin mukaan almanakkaan. Yliopisto hyväksyi ehdotuksen, ja vuodesta 1968 alkaen almanakassa on ollut merkintä $Y K: n$ päivästä.

Viralliseksi liputuspäiväksi ei YK:n päivää kelpuutettu, mutta liputuspäiväksi se on kuitenkin vakiintunut. Yliopiston almanakassa 24.10. on ollut lipulla merkittynä vuodesta 1987 alkaen.

Liputuksen ohella YK:n päivä on näkynyt julkisuudessa laajojen rauhanmarssien ansiosta.

YK on valinnut vuoden varrelle useita merkki- ja teemapäiviä, joita se suosittelee vietettäväksi kaikissa jäsenvaltioissaan. Seuraavan aukeaman laatikossa on lueteltu YK:n suosittelemia päiviä. Näistä kansainvälinen naistenpäivä, YK:n päivä ja lasten päivä on otettu mukaan suomalaiseen almanakkaan.

Aleksis Kiven patsas Helsingin Rautatientorilla Kansallisteatterin edessä. Kivellä on patsas lisäksi ainakin Nurmijärvellä ja Tampereella.

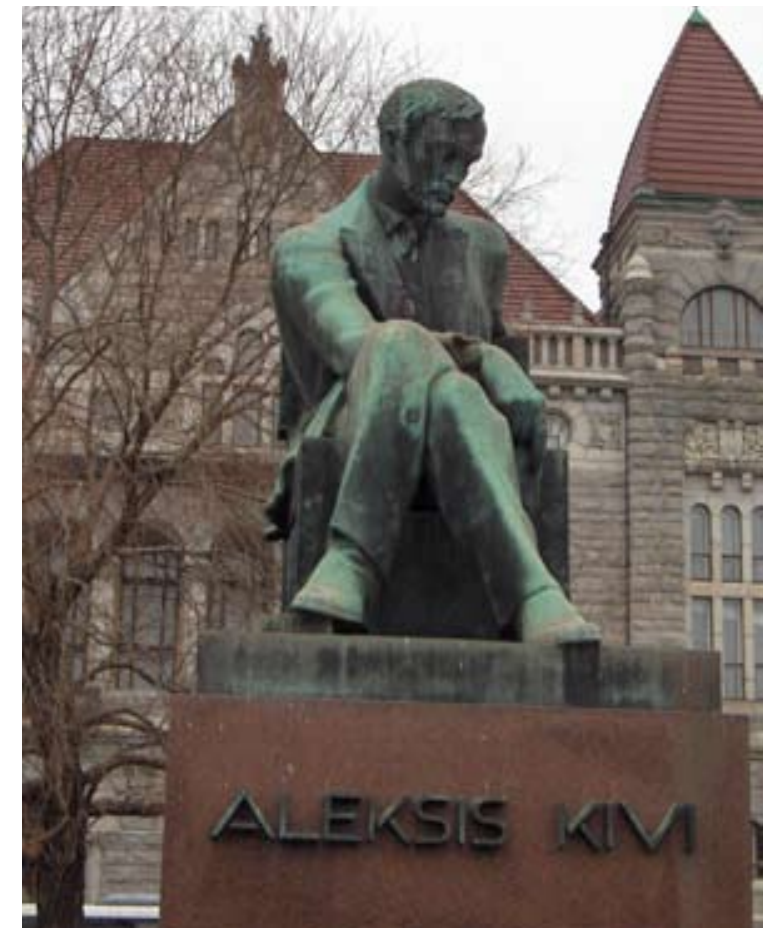




\section{YK:n teemapäivät}

uettelossa on Yhdistyneiden kansakuntien suosittelemia vuosittaisia L teemapäiviä. Luettelo perustuu YK:n sivulla http://www.un.org/en/ events/observances/days.shtml oleviin tietoihin vuoden 2013 alussa. Kv. tarkoittaa kansainvälinen.

\section{7. tammikuuta Kv. holokaustin uhrien muistopäivä \\ 4. helmikuuta \\ Maailman syöpäpäivä}

6. helmikuuta

13. helmikuuuta

20. helmikuuta

21. helmikuuta

8. maaliskuuta

20. maaliskuuta

21. maaliskuuta

22. maaliskuuta

23. maaliskuuta

25. maaliskuuta

2. huhtikuuta

4. huhtikuuta

7. huhtikuuta

12. huhtikuuta

23. huhtikuuta

3. toukokuuta

8. - 9. toukokuuta

15. toukokuuta

17. toukokuuta

21. toukokuuta

22. toukokuuta

29. toukokuuta

31. toukokuuta

4. kesäkuuta

5. kesäkuuta

8. kesäkuuta

12. kesäkuuta

17. kesäkuuta

20. kesäkuuta

23. kesäkuuta

26. kesäkuuta

26. kesäkuuta
Kv. päivä naisten sukuelinten silpomista vastaan

Maailman radiopäivä

Sosiaalisen oikeudenmukaisuuden päivä

Kv. äidinkielen päivä

Kv. naistenpäivä

Kv. onnellisuuspäivä

Kv. päivä rotusyrjinnän poistamiseksi

Kv. veden päivä

Maailman ilmatieteen päivä

Kv. orjuuden uhrien muistopäivä

Maailman autismitietoisuuden päivä

Kv. miinojen vastainen päivä

Maailman terveyspäivä

Kv. ihmisen avaruuslennon päivä

Maailman kirjan ja tekijänoikeuksien päivä

Kv. lehdistönvapauden päivä

Toisen maailmansodan uhrien muistopäivä

Kv. perheiden päivä

Maailman tietoyhteiskuntapäivä

Kv. kulttuurisen monimuotoisuuden päivä

Kv. luonnon monimuotoisuuden päivä

Kv. rauhanturvaajien päivä

Kv. tupakaton päivà

Hyökkäyksen uhreiksi joutuneiden lasten muistop.

Maailman ympäristöpäivä

Maailman merien päivä

Kv. päivä lapsityön estämiseksi

Aavikoitumisen ja kuivuuden ehkäisemispäivä

Maailman pakolaispäivä

YK:n julkisen palvelun päivä

Kv. päivä huumeiden väärinkäytön ja huumaus-

ainekaupan vastustamiseksi

Kv. päivä kidutuksen uhrien puolesta heinäkuun ensimmäinen lauantai Kv. osuustoiminnan päivä

11. heinäkuuta Maailman väestöpäivä

9. elokuuta Kv. maailman alkuperäiskansojen päivä

12. elokuuta Kv. nuorisopäivä

29. elokuuta Kv. päivä ydinkokeita vastaan

8. syyskuuta

15. syyskuuta

16. syyskuuta

21. syyskuuta

valinnainen päivä kuun viim. viikolla Maailman merenkulkupäivä

1. lokakuuta Kv. ikääntyneiden päivä

2. lokakuuta Kv. väkivallattomuuden päivä

5. lokakuuta Maailman opettajien päivä

lokakuun ensimmäinen maanantai Maailman Habitat-päivä (asumis-

9. lokakuuta

10. lokakuuta

13. lokakuuta

15. lokakuuta

16. lokakuuta

17. lokakuuta

24. lokakuuta

6. marraskuuta

14. marraskuuta

16. marraskuuta

marraskuun kolmas sunnuntai Maailman tieliikenneuhrien muistop.

20. marraskuuta Yleinen lasten päivä

20. marraskuuta Afrikan teollisen kehittämisen päivä

21. marraskuuta Maailman televisiopäivä

25. marraskuuta Kv. päivä naisiin kohdistuvan väkivallan

lopettamiseksi

29. marraskuuta Kv. päivä solidaarisuuden osoittamiseksi Palestiinan kansalle

1. joulukuuta Kv. AIDS-päivä

3. joulukuuta Kv. vammaisten päivä

5. joulukuuta

7. joulukuuta

9. joulukuuta

10. joulukuuta

11. joulukuuta

18. joulukuuta

20. joulukuuta

Kv. siviili-ilmailun päivä

Kv. korruptionvastainen päivä

Ihmisoikeuksien päivä

Kv. vuoristopäivä

Kv. siirtolaisten päivä

Kv. inhimillisen solidaarisuuden päivä 


\section{Marraskuu: Ruotsalaiset, isät ja lapset}

Ruotsi-Suomen sankarikuningas Kustaa II Aadolf sai surmansa Puolassa Lützenin taistelussa marraskuun 6. päivänä 1632. Päivää on Ruotsissa vietetty Kustaa Aadolfin päivänä.

Suomeen perustettiin 1906 ruotsalainen kansanpuolue, ja se päätti seuraavana vuonna ruveta viettämään erityistä ruotsalaisuuden päivää. Kustaa Aadolfin päivä 6.11. katsottiin meilläkin sopivimmaksi päivämääräksi.

Kaikki suomenmieliset eivät 1900-luvun alkupuolella sulattaneet ruotsalaisuuden päivän viettoa. Nykyään kansallisuusaatteet ovat jäämässä taka-alalle ja Suomi ja Ruotsi liittyivät esimerkiksi yhtä aikaa EU:n jäseniksi. Ruotsalaisuuden päivä on saanut uutta kansainvälistä ilmettä.

Yliopiston almanakkaan ruotsalaisuuden päivä on ollut merkittynä vuodesta 1979 alkaen, jolloin se ensimmäisen kerran mainittiin vakiintuneeksi liputuspäiväksi. Päivällä on ollut myös Kustaa Aadolfin nimipäivä. Koska Kustaalla ja Aadolfilla on jo erikseen nimipäivät muuhun aikaan vuotta, päätti Helsingin yliopisto poistaa nimipäiväuudistuksen 2010 yhteydessä Kustaa Aadolfin nimipäivän ja ottaa sankarikuninkaan mukaan itse päivän nimeen. Niinpä päivä on nykyään ruotsalaisuuden päivä, Kustaa Aadolfin päivä, eikä päivällä ole kenenkään nimipäivää.

Isänpäivän idea syntyi Yhdysvalloissa pian äitienpäivän keksimisen jälkeen. Isänpäivä ei kuitenkaan saanut aikaan samankaltaista innostusta eikä edes sen päivämäärästä päästy yksimielisyyteen.

Pohjoismaiset kauppiaat ehdottivat 1940-luvun lopulla, että isänpäivää ruvettaisiin viettämään marraskuun toisena sunnuntaina, aikana jolloin kaupoissa on vielä hiljaista ennen joulusesongin alkua. Ajatus levisi hitaasti, mutta 1970-luvulle tultaessa isänpäivä alkoi vakiinnuttaa asemaansa Suomessa. Yliopiston almanakkaan päivä oli merkittynä ilman yliopiston päätöstä 1970-72, mutta kun asia huomattiin, päivän merkintä poistettiin.

Vasta 1987 yliopisto katsoi isänpäivän niin vakiintuneeksi, että se hyväksyttiin takaisin almanakkaan. Samasta vuodesta alkaen se on merkitty liputuspäiväksi.

Vaikka isänpäivää vietetäänkin jonkin verran perhepiirissä, se on Suomessa katsottu ennen kaikkea kaupalliseksi juhlaksi, joka on vailla suurempaa aatteellista merkitystä.
Lastenpäivää vietettiin Suomessa kymmenen vuoden ajan lokakuun ensimmäisenä maanantaina, mutta 2002 alkaen käytäntö muuttui ja lapsille omistettu päivä on nykyään marraskuun kahdeskymmenes.

Aikaisempi lastenpäivän paikka perustui Suomen Unicef-yhdistyksen aloitteeseen vuodelta 1991. Tällöin Unicef-yhdistys esitti, että kalenteriin merkittäisiin kansainvälinen lastenpäivä. Jo joulukuussa 1954 kehotti YK:n yleiskokouksen julkilausuma kaikkia jäsenvaltioita viettämään lokakuun ensimmäistä maanantaita kansainvälisenä lastenpäivänä.

Kansainvälinen käytäntö muuttui hieman 1990-luvulla, ja tärkeämmäksi lastenpäiväksi kohosi lapsen oikeuksien päivä 20.11. Päivämäärä juontuu alun perin vuodelta 1959, jolloin saatiin aikaan ensimmäinen lapsen oikeuksien julistus, ja vuodelta 1989, jolloin täydellisempi lapsen oikeuksien sopimus hyväksyttiin samalla päivämäärällä YK:n yleiskokouksessa.

Mannerheimin Lastensuojeluliitto oli 1980-luvulta alkaen ehdottanut lapsen oikeuksien päivän 20.11. merkitsemistä almanakkaan. Syksyllä 1999 myös Suomen Unicef-yhdistys ehdotti päivän merkitsemistä. Helsingin yliopistossa todettiin, että almanakkaan voidaan merkitä vain yksi lapsille omistettu päivä, ja niin sovittiin lastenpäivän siirto lokakuulta marraskuulle.

\section{Joulukuu: Itsenäisyys ja Sibelius}

Vuoden lopulle sattuu kansallisista merkkipäivistämme juhlavin, itsenäisyyspäivä. Joulukuun 6. päivänä vuonna 1917 eduskunta hyväksyi Suomen itsenäisyysjulistuksen. Koska itsenäistymiseen liittyviä päätöksiä tehtiin useilla muillakin päivämäärillä, käytiin seuraavina vuosina keskustelua siitä, mikä päivämäärä Suomen "syntymäpäiväksi" valittaisiin.

Kesti kaksi vuotta, marraskuuhun 1919, ennen kuin valtioneuvosto pystyi tekemään päätöksen, että juuri joulukuun 6. päivää vietetään Suomen itsenäiseksi julistamisen vuosipäivänä. Virastoissa, kouluissa ja tuomiokunnissa oli vapaapäivä, ja julkiset rakennukset nostivat lipun salkoon.

Kymmenen vuotta myöhemmin, 1929, säädettiin itsenäisyyspäivä yleiseksi palkalliseksi vapaapäiväksi. Itsenäisyyspäivä rauhoitettiin samanlaiseksi kuin pyhäpäivät, ja esimerkiksi markkinoiden, torikauppojen ja huutokauppojen pito kiellettiin. 
Almanakkaan itsenäisyyspäivä on ollut merkittynä vuodesta 1934 alkaen. Samana vuonna se määrättiin viralliseksi liputuspäiväksi.

Nykyään itsenäisyyspäivää juhlistavat lippujen lisäksi esimerkiksi soihtukulkueet, presidentin vastaanotto ja kynttilöiden polttaminen kotien ikkunoilla.

Vuonna 2011 tuli almanakkoihin joulukuulle uusi liputuspäivä, Jean Sibeliuksen päivä, suomalaisen musiikin päivä.

Sisäasiainministeriö oli vuodesta 2005 alkaen antanut vuosittain suosituksen yleisestä liputtamisesta Sibeliuksen syntymäpäivänä 8.12. Koska sisäministeriön kokemukset olivat olleet positiivisia, sisäministeriö ehdotti vuoden 2007 lopulla, että Helsingin yliopiston almanakkatoimisto ryhtyisi toimenpiteisiin joulukuun 8. päivän merkitsemiseksi kalentereihin liputuspäiväksi.

Yliopistossa päätettiin, että Sibeliuksen päivä merkitään kalentereihin vuosikerrasta 2011 alkaen. Samalla päivälle annettiin lisämääre suomalaisen musiikin päivä.

Sibeliuksen päivä on joulukuussa, jolloin pohjoisimmassa Suomessa ei aurinko näy lainkaan. Nykyisten säännösten mukaan pitäisi liputuspäivänä liputtaa kello 8:sta auringonlaskuun. Jotta Pohjois-Suomikin voi kunnioittaa Sibeliusta, suositellaan Sibeliuksen päivänä liputusta kaikkialla Suomessa kello 8-16.

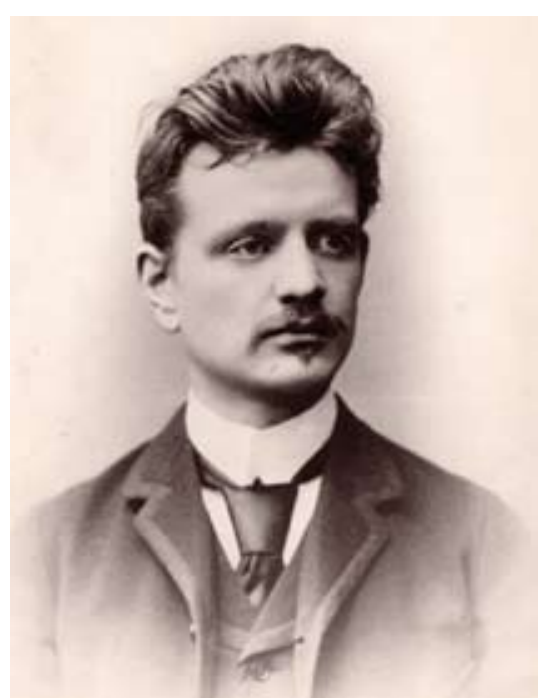

Jean Sibelius (1865-1957) sai syntymäpäivänsä almanakkaan vuosikerrasta 2011 lähtien. Kuvassa Sibelius nuorena musiikinopiskelijana 1800-luvun lopulla. (Kuva Wikipedia)

\section{Miten merkkipäivä pääsee almanakkaan?}

Tärkeimmät kansalliset merkkipäivät ovat tulleet juhlakalenteriin valtiollisilla päätöksillä. Tällaisia ovat tietysti itsenäisyyspäivä, mutta myös esimerkiksi puolustusvoimain lippujuhla, kaatuneitten muistopäivä ja veteraanipäivä.

Toinen tie merkkipäivän vakiinnuttamisessa kulkee Helsingin yliopiston kautta. Yliopiston keltakantinen kansanalmanakka oli menneinä vuosisatoina maamme ainoa kalenteri, ja edelleenkin Yliopiston almanakkaa pidetään - Suomen Valtiokalenterin ohella - "virallisena" kalenterinamme.

Ykkösaseman säilyttämisessä auttaa se, että kansanalmanakka on myytävistä almanakoista ehdottomasti laajalevikkisin. Sen painosmäärä on edelleenkin sadantuhannen luokkaa. Jos merkkipäivä pääsee mukaan Yliopiston almanakkaan, tieto päivästä leviää koko kansan keskuuteen.

Kun Yliopiston almanakkatoimisto saa ehdotuksen uudesta merkkipäivästä, siitä pyydetään yleensä lausunto yliopiston asiantuntijalta.

Jos päivä päätetään ottaa mukaan Yliopiston almanakkaan, se samalla tulee automaattisesti mukaan lähes kaikkiin muihinkin suomalaisiin kalentereihin. Yliopiston almanakkatoimisto nimittäin merkitsee päivän omaan "päivälistaansa", jonka suosituksia useimmat suomalaiset kalenterinvalmistajat noudattavat.

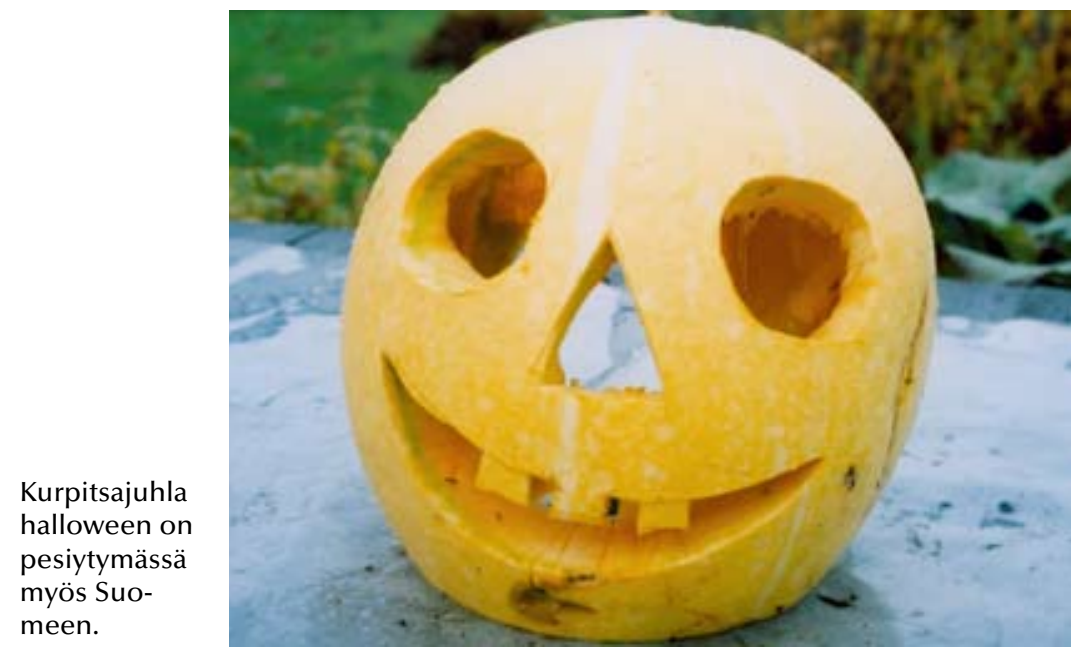


Kolmas tie uuden merkkipäivän vakiintumisessa on kaupallisuus ja julkisuus. Jos uuden päivän lanseeraamisessa ovat mukana tarpeeksi voimakkaat taustaryhmät ja tarpeeksi suuri kaupallinen mielenkiinto, tulee päivä Suomeen riippumatta siitä, haluaako tavallinen meikäläinen sitä vai ei.

Viime vuosikymmeninä ovat meille tulleet tällä tavalla isänpäivä ja ystävänpäivä. Jos tällainen kauppatapahtuma nousee vuosittain toistuvaksi, ottaa yliopistokin päivän lopulta almanakkaansa.

\section{Uusia yrittäjiä kalenteripäiviksi}

Helsingin yliopisto saa vuosittain muutamia vakavasti otettavia ehdotuksia uusiksi kalenteripäiviksi. Esimerkiksi vanhusjärjestöt ehdottivat jokin aika sitten, että almanakkaan merkittäisiin lokakuun kolmas lauantai isovanhempien päiväksi.

Yliopisto pyysi isovanhempien päivästä lausunnon kansatieteen asian-

\section{Uusia merkkipäiviä}

uomalaisiin kalentereihin ehdotettuja uusia merkkipäiviä, joita ei ole ainakaan toistaiseksi hyväksytty mukaan.

$\underline{\text { Pvm Päivä }}$

\section{$\underline{\text { Huomautuksia }}$}

14.1. Zacharias Topeliuksen Mainittu useaan otteeseen mahdolliseksi päivä

24.1. Inkerin päivä

3.2. Alvar Aallon päivä

24.2. Viron kansallispäivä

23.3. Pohjolan päivä

1.4. Aprillipäivä

Kesäkuu Saunapäivä liputuspäiväksi.

Juhlittiin 1943-44 heimotyön merkeissä.

Ehdotettu suomalaisen arkkitehtuurin ja muotoilun päiväksi.

Viron itsenäisyyspäivä (1918), ehdotettu

meilläkin liputuspäiväksi.

Sisäministeriö suositteli vuonna 2002

liputtamista, ehdotettiin ensimmäisen

kerran jo 1976.

Vakiintunut, mutta teho perustuu yllätyksellisyyteen. Ei merkitä almanakkaan.

Saunaseuran ehdotus, yliopisto ei hyväksynyt almanakkaan.

tuntijalta. Lausunto totesi, että isovanhempien merkitys on tietysti suuri, mutta omaa nimikkopäivää ei kuitenkaan liene syytä merkitä. Asiantuntija katsoi, että isovanhempia voi jo nykyään juhlia - ja juhlitaankin - äitien- ja isänpäivänä. Isovanhempien oma päivä ei ole niin vakiintunut suomalaiseen kulttuuriin, että se pitäisi merkitä almanakkaan.

Isovanhempien päivä on yksi esimerkki kymmenistä erilaisista merkkitai teemapäivistä, joita jossakin vaiheessa on ehdotettu almanakkaamme. Muutamien ehdotettujen merkkipäivien aika on jo selvästi ohi, mutta toiset ovat vasta nousemassa.

Oheisessa laatikossa on luetteloa almanakkaan pyrkineistä tai pyrkivistä merkkipäivistä.

Mitkä päivät kalentereihimme seuraavaksi hyväksytään? Yliopisto ei kovin helpolla uusia merkkipäiviä ota, vaan päivän täytyy olla laajalti vietetty ja tunnettu ja vakiintunut maamme kulttuuriin.

Yksi päivä, jonka vietto on selvästi laajenemassa, on Amerikasta lainattu kurpitsajuhla, halloween. Kaupoissa myydään erilaisia noita- ja

13.6. Paavo Nurmen päivä

14.7. Jaakko Juteinin päivä

17.7. Kansanvallan päivä

1.10. Vanhustenpäivä

18.10. Johannes Linnankosken päivä

Lokakuu Heimopäivä

Lokakuu Isovanhempien päivä

8.11. H.G. Porthanin päivä

13.12. Lucianpäivä
Suomalaisuuden liitto mainitsee ehdotettuna suomalaisen urheilun päivänä.

Suomalaisuuden liitto mainitsee ehdotettuna suomalaisuuden päivänä.

Suomen hallitusmuodon vahvistaminen tasavallaksi 17.7.1919. Vietettiin 1992, oli merkittynä almanakkaan 1994.

YK:n suosittelema päivä, jota Vanhustyön keskusliitto on ehdottanut almanakkaan Yritettiin 1940-luvulla suomalaisen kirjallisuuden viikon (10.10.-18.10.) päättäjäispäiväksi.

Vietettiin 1930-luvulla lokak. kolmantena lauantaina Suomessa, Virossa ja Unkarissa. Vanhus- ja lähimmäispalvelun liiton ehdotus, lokakuun kolmas lauantai, yliopisto ei ole hyväksynyt almanakkaan.

Ehdotettiin 1800-luvulla juhlapäiväksi, mutta ei vakiintunut.

Vietetään suomenruotsalaisten piirissä, tulossa myös suomenkieliselle puolelle. 
kummitustavaroita, ja päiväkoti- ja kouluikäiset tuntuvat päivästä hyvin innostuneilta. Halloweenissa on kyllä harmittoman, muista päivistä eroavan juhlan aineksia.

Sana halloween tulee englantilaisista sanoista, jotka merkitsevät pyhäinpäivän aattoa. Pyhäinpäivä on useimmissa muissa maissa perinteisellä paikallaan 1.11., joten halloweenin päivämäärä on näissä maissa selvä, 31.10 .

Kaupan piirissä mietittiin 1990-luvun lopulla meikäläisen halloweenin sijoittelua ja päädyttiin siihen, että päivää ei meillä sidota pyhäinpäivään. Kauppiaat arvelivat, että iloinen halloween on syytä pitää erillään vakavammasta pyhäinpäivästä.

Niinpä Erikoiskaupan Liitto antoi syksyllä 1999 suosituksen, jonka mukaan halloweenin päivämäärä Suomessa on kansainväliseen tapaan lokakuun viimeinen päivä, 31.10., riippumatta siitä, mille viikonpäivälle se sattuu. Yliopiston almanakkaan tai almanakkatoimiston päivälistaan ei halloweenia vielä merkitä.

Uusia suomalaisia merkkipäiviä ei allakkaan ole ainakaan ihan heti tiedossa. Nyt kun Sibeliuksen päivä on otettu almanakkaan ja Eurooppa-päivälle on tullut lipunkuva, ei uusia liputuspäiviä ole vähään aikaan näkyvissä. "Sekä Canthin että Sibeliuksen liputuspäivien puolesta tuli esityksiä laajalti ja välillä varsin runsaastikin aina 1980-luvulta asti",

18

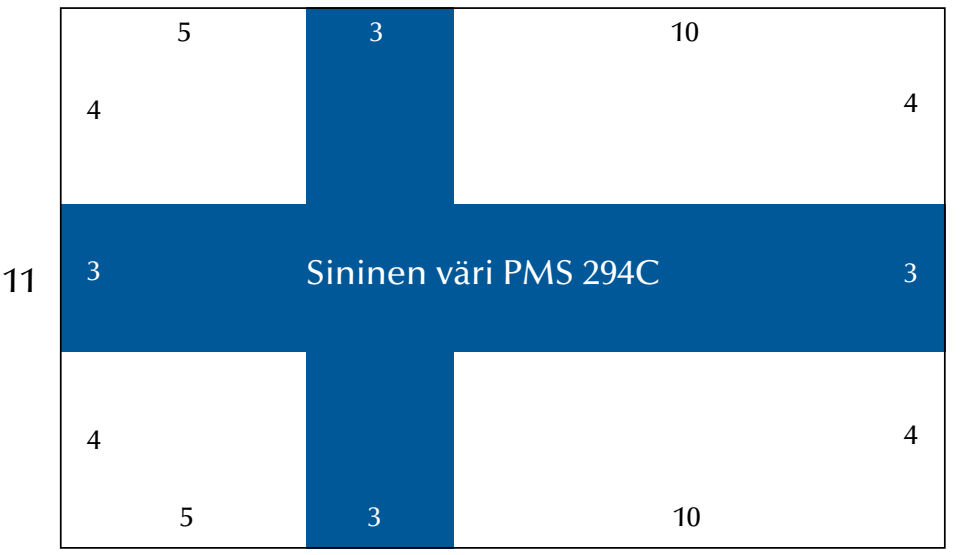

Suomen lipun mittasuhteet ja värit on säädetty tarkasti laissa ja asetuksessa. kertoo hallitusneuvos Ismo Atosuo sisäasiainministeriöstä. "Samanlaista liikettä jonkin muun uuden päivän puolesta ei ole."

\section{Suomalainen liputuskäytäntö}

Suomen itsenäistyttyä 1917 ei ollut yksimielisyyttä siitä, millainen on Suomen lippu ja milloin sitä käytettäisiin. Kilpailevina ehdotuksina oli punakeltainen leijonalippu ja sinivalkoinen ristilippu. Jälkimmäinen vei voiton ja valittiin 1918 Suomen valtiolipuksi. Lipun käyttämisestä annettiin asetukset 1920 ja 1934.

Lippulainsäädäntö uusittiin 1978-1996. Vuoden 1978 laki määrää tarkasti esimerkiksi Suomen lipun mittasuhteet. Katujen varsilla liehuvat liput ovat oikeanmuotoisia, mutta painotuotteissa näkyy milloin minkinlaisia lipunkuvatuksia.

Lain mukaan lipun korkeus on 11 ja pituus 18 mittayksikköä, sinisen sakaran leveys 3 mittayksikköä ja valkoisten nurkkakenttien korkeus 4 ja leveydet 5 ja 10 mittayksikköä.

Lipun väreistä annettiin asetus vuonna 1993. Värit määritellään usean eri standardin mukaan, joista käyttökelpoisin näin tietokoneaikaan on PMS-standardi: Suomen lipun sininen väri vastaa PMS-väriä 294C.

Liputuslain mukaan jokaisella on oikeus liputtaa kansallislipulla kun katsoo siihen olevan aihetta. Lipun voi nostaa salkoon yksityistaloissa vaikkapa nimi- tai syntymäpäivän, ylioppilasjuhlan tai muun sukujuhlan kunniaksi ja yrityksissä esimerkiksi mieluisien vieraiden juhlistamiseksi.

Liputusasetus määrää tarkasti ne päivät, jolloin valtion rakennuksissa pitää liputtaa. Näinä ns. virallisina liputuspäivinä nostetaan liput salkoihin myös muualla Suomessa. Asetus luettelee kuusi jokavuotista liputuspäivää, seitsemäntenä erilaiset vaalipäivät ja kahdeksantena presidentin virkaanastujaispäivän. Päivät on lueteltu oheisessa taulukossa.

Virallisten päivien lisäksi maassamme on kolmetoista muuta liputuspäivää. Ne mainitaan useimmissa kalentereissa, ja päivät on lueteltu seuraavan aukeaman taulukossa.

Siniristilipun lisäksi Suomessa hulmuavat muutkin liput. Ahvenanmaalla on oma sinipohjainen maakuntalippunsa, jossa on punakeltainen risti. Lapissa taas liehuu saamelaisten heimolippu, jossa on perinteisen Lapin puvun värit, punaista, vihreää, keltaista ja tummansinistä. Ja yhä useammassa paikassa näkyy EU:n tummansininen lippu, jossa on kaksi- 


\section{Liputuspäivät Suomessa}

okaisella suomalaisella on oikeus liputtaa kansallislipulla aina, kun hän näkee liputuksen aiheelliseksi. Liputus aloitetaan aamulla kello 8 ja lopetetaan auringon laskiessa, kesälläkin viimeistään kello 21. Suomen lipun päivän liputus alkaa juhannusaattona kello 18 ja päättyy juhannuspäivänä kello 21. Itsenäisyyspäivänä ja sellaisena vaalipäivänä, jolloin äänestys päättyy auringonlaskun jälkeen, liputus päättyy kello 20. Ajat koskevat valtion virastoja ja laitoksia, muille ajat ovat vain viitteelliset. Vuosittaiset liputuspäivät löytyvät sivulta www.liputus.fi (ruotsiksi www.flaggning.fi).

\section{Viralliset, laissa määrätyt liputuspäivät}

$\boxplus$ 28.2. Kalevalan päivä, suomalaisen kulttuurin päivä

$\boxplus$ 1.5. Vappu, suomalaisen työn päivä

Ф Toukokuun toinen sunnuntai, äitienpäivä

$\boxplus$ 4.6. Puolustusvoimain lippujuhlan päivä

$\boxplus$ Kesäkuun 20. ja 26. päivän välinen lauantai, juhannus, Suomen lipun päivä

円6.12. Itsenäisyyspäivä

¥ Päivä, jolloin toimitetaan valtiolliset vaalit, kunnallisvaalit, Euroopan parlamentin edustajien vaalit tai neuvoa-antava kansanäänestys koko maassa

$\boxplus$ Päivä, jolloin tasavallan presidentti astuu toimeensa

\section{Muut liputuspäivät eli ns. vakiintuneet liputuspäivät sekä ne} päivät, joina sisäministeriö on useana vuonna suositellut liputusta

由5.2. J.L. Runebergin päivä

円 19.3. Minna Canthin päivä, tasa-arvon päivä

¥9.4. Mikael Agricolan päivä, suomen kielen päivä

$\boxplus$ 27.4. Kansallinen veteraanipäivä

¥12.5. J.V. Snellmanin päivä, suomalaisuuden päivä

$\boxplus$ 9.5. Eurooppa-päivä

toista tähteä. Ahvenanmaan lippu on vuodelta 1954, ja saamelaisten ja EU:n lippu on kumpikin vahvistettu 1986.

Ahvenanmaalla on kolme omaa liputuspäivää, uusimpana (vuodesta 2000 alkaen) Ahvenanmaan neutralisoinnin ja demilitarisoinnin juhlapäivä 30.3. Päivämäärä on saatu niinkin kaukaa kuin vuodesta 1856, jolloin Ahvenanamaan asemaa koskeva sopimus allekirjoitettiin Pariisis- $\boxplus$ Toukokuun kolmas sunnuntai, kaatuneitten muistopäivä ஐ 6.7. Eino Leinon päivä, runon ja suven päivä

$\boxplus$ 10.10. Aleksis Kiven päivä, suomalaisen kirjallisuuden päivä 円 24.10. YK:n päivä

$\boxplus$ 6.11. Ruotsalaisuuden päivä, Kustaa Aadolfin päivä

Ф Marraskuun toinen sunnuntai, isänpäivä

$\boxplus$ 8.12. Jean Sibeliuksen päivä, suomalaisen musiikin päivä

\section{Ahvenanmaan omat liputuspäivät \\ 30.3. Ahvenanmaan neutralisoinnin ja demilitarisoinnin juhlapäivä \\ Huhtikuun viimeinen sunnuntai, Ahve- nanmaan lipun päivä \\ 9.6. Ahvenanmaan itse- hallintopäivä}

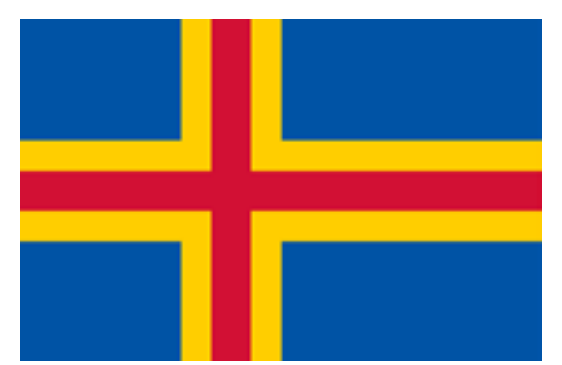

\section{Saamelaisten omat liputuspäivät}

(1) 6.2. Saamelaisten kansallispäivä

(10) 2.3. Suomen saamelaiskäräjien perustamispäivă

(1) Marianpäivä, saamelaisten perinteinen juhlapäivä

(1) Juhannuspäivä, yleinen juhlapäivä

(1) 9.8. YK:n kansainvälinen alkuperäiskansojen päivä

(1) 15.8. Saamen lipun hyväksymispäivä (1986)

(1) 18.8. Saamelaisneuvoston perustamispäivä (1956)

(1) 26.8. Ruotsin saamelaiskäräjien perustamispäivä

(1) 9.10. Norjan saamelaiskäräjien perustamispäivä

(1) 9.11. Saamelaisvaltuuskunnan perustamispäivä (1973)

(D) 15.11. Isak Saban syntymäpäivä (1875)

sa. Saamelaisilla on nykyään yksitoista liputuspäivää. Päivät on lueteltu ylläolevassa taulukossa.

EU:n lipulle ei ole määritelty omia liputuspäiviä, mutta EU-lippu nostetaan salkoon esimerkiksi silloin, kun suomalaiseen yritykseen tai laitokseen tulee vieraita EU:sta.

Helsingin yliopiston almanakkatoimisto avasi syksyllä 2009 omat 
liputussivunsa osoitteessa www.liputus.fi, ruotsiksi www.flaggning.fi. Sivuilta löytyy mm. kuluvan ja seuraavan vuoden täydellinen liputuspäiväluettelo, joka on kaikkien kalenterinjulkaisijoiden käytettävissä. Sivuilla on myös liputuksen kellonaikasuositukset kaikille liputuspäiville, hieman historiikkia siitä miten liputuspäivät ovat olleet merkittyinä Yliopiston almanakkaan sekä linkit virallisiin liputusasetuksiin. Edelleen sivuilta löytyvät linkit sisäministeriön ja Suomalaisuuden liiton monipuolisille liputussivuille.

\section{Kansan omat merkkipäivät}

Suomen kansa on juhlinut omia merkkipäiviään paljon ennen kuin keisari on käskyttänyt nimipäivänsä vieton tai nykyinen kansallinen juhlakalenteri on muotoutunut. Vanhat merkkipäivät elävät edelleen kansan keskuudessa esimerkiksi säähän ja tapoihin liittyvinä sananparsina.

Suuri osa kansan merkkipäivistä liittyy kirkollisiin juhlapäiviin. Kirkkopyhiin on kietoutunut vanhempien pakanallisten juhlien aineksia, ja kristillisten tapojen oheen on päiviin keräytynyt maallisia juhlanviettotapoja.

Kirkollisten juhlien ulkopuoliset merkkipäivät liittyvät yleensä pyhimyskalenteriin. Almanakoissamme oli entisinä vuosisatoina enimmäkseen perinteisiä pyhimysten nimiä, ja kuhunkin vuodenaikaan tai juhlakauteen liittyvät merkkipäivät saivat nimensä pyhimyksestä. Pyhimysten nimet vain väännettiin suomalaisten suussa paremmin istuvaan muotoon.

Kustaa Vilkuna on kirjassaan Vuotuinen ajantieto kuvaillut suomalaisen kansanperinteen merkkipäiviä. Tässä mainitaan lyhyesti vain huomattavimmat.

Tammikuussa loppiaista seuraava päivä, 7.1., on "vanha nuutti", jota entisaikaan pidettiin joulunajan lopettamispäivänä. Herrasväen piirissä joulua voitiin viettää "uuteen nuuttiin" eli tammikuun 13. päivään asti. Nuutin päivä siirtyi almanakassamme 7:nnestä 13:nteen jo 1708 . Heikin päivää 19.1. on vanhastaan pidetty talven keskikohtana, jolloin karhu kääntää kylkeä ja talven selkä paukahtaa poikki.

Helmikuun alussa vietettävä laskiainen on Suomessa saanut omaa kansanperinteeseen liittyvää sisältöä. Nykysukupolvi yhdistää laskiaisen - laskiaispullan ja hernesopan ohella - ennen kaikkea mäenlaskuun ja

\section{Miksi aprillipäivä ei ole almanakassa?}

"A prillia, syö silliä, juo kuravettä päälle!" Joka vuosi huhtikuun 1. päiväInä keksitään taas uusia piloja, joilla juksataan herkkäuskoisia.

Yksi tarina kertoo aprillipäivän olevan peräisin Ranskasta yli neljänsadan vuoden takaa. Kuningas Kaarle IX:n päätöksellä Ranska siirtyi 1564 uuteen kalenteriin, jossa vuosi alkoi tammikuun alussa. Kaikki ranskalaiset eivät kuitenkaan sulattaneet päätöstä, vaan pitivät edelleen uudenvuodenjuhliaan ja antoivat uudenvuodenlahjojaan vanhana uutenavuotena, huhtikuun 1. päivänä. Muualla Ranskassa näistä jääräpäistä alettiin tehdä pilkkaa, ja vähitellen aprillipäivän pilailut levisivät muihinkin maihin.

Suomeen aprillaus tuli 1700-luvulla, ensin säätyläis-

ten keskuuteen, sitten koko kansan huviksi.

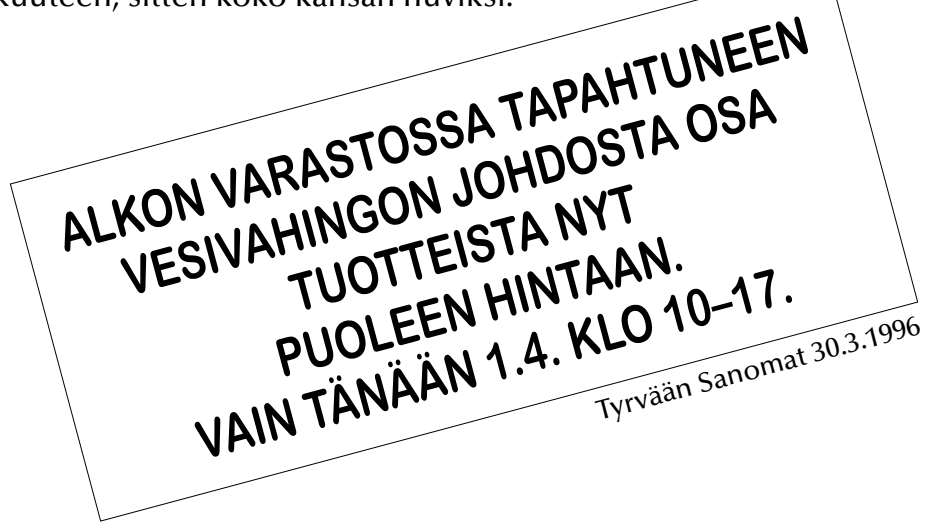

Aprillipäivä on varmaan tunnetuin nykyajan merkkipäivä, joka ei ole mainittuna Yliopiston almanakassa. Sen mukaanottoa on välillä harkittu, mutta päivä on aina päätetty jättää merkitsemättä. Aprillipäivän idea perustuu juuri sen yllätyksellisyyteen. Jos päivä olisi almanakassa, pilojen teho voisi latistua.

hevosajeluihin. Laskiaismäessä on toivoteltu "pitkiä pellavia" eli hyvää satovuotta seuraavan kesän kasvukaudelle. Helmikuun 24. päivä eli Talvi-Matti on kevätkauden alkupäivä, jolloin kaivojen vesi on alimmillaan ja aurinko alkaa jo sulatella räystäitä.

Maaliskuun Kevät-Maaria (25.3.) saattoi jo näyttää maassa ensim- 
mäiset paljaat läikät, ja marianpäivän säästä ennusteltiin kevääntulon nopeutta.

Huhtikuun 14. päivä oli ennen vanhaan Tiburtiuksen päivä, ja tällöin almanakassa luki "suwi-päivä". Vuosi jaettiin tuolloin kahteen puolikkaaseen, kesä- ja talvipuoliskoon, ja 14.4. oli ensimmäinen kesäpäivä. Yrjön päivänä 23.4. ajettiin karja ulos laitumelle ja Markun päivänä 25.4. tai valpurina 1.5. käki kertoi kesän lähestyvän.

Toukokuun 3. päivä oli keskiajalla Ristin päivä, jota juhlittiin karjanhoidon ja kalastuksen merkkipäivänä. Ateriana syötiin kalakeittoa. Ortodoksit juhlivat toista Ristin päivää syksyllä (ks. luku 5).

Kesäkuun suurin juhla on tietysti juhannus. Kesäkuun pienemmät merkkipäivät liittyvät kylvötöihin. Kustaana (6.6.) piti panna peruna maahan. Nauriiden kylvö onnistui parhaiten Eskona (12.6.), Pietarina (29.6.) tai juhannusta seuraavana "ituperjantaina", joka on aina Pietarin päivän lähellä.

Heinäkuun loppupuolta ja elokuun alkupuolta sanotaan "mätäkuuksi", koska haavat pyrkivät helposti märkimään. Mätäkuun nimi on kuitenkin käännösvirhe, sillä muissa maissa tämä aika tunnetaan "koirakuuna". Vanhassa Egyptissä tähän aikaan taivaalle ilmestyi "Koiratähti" Sirius, joka toi mukanaan kesän kuumimman ajan.

Heinäkuun 18. ja 24. päivän välillä on almanakassa "naistenviikko", jolloin on pelkkiä naisten nimipäiviä. Ja naistenviikkohan ei tunnetusti mene ilman sateita. Heti naistenviikon jälkeen on Jaakon päivä. Raamatullinen Jaakko on ollut suomalaisille läheinen pyhimys. Nykyajankin lapset tietävät, että Jaakko heittää kylmän kiven veteen ja uimakausi alkaa olla lopussa. Tämä perinnetieto on ilmeisesti syntynyt ennen vuotta 1753, jolloin Jaakon päivä vastasi nykyistä elokuun alkua. Mittausten

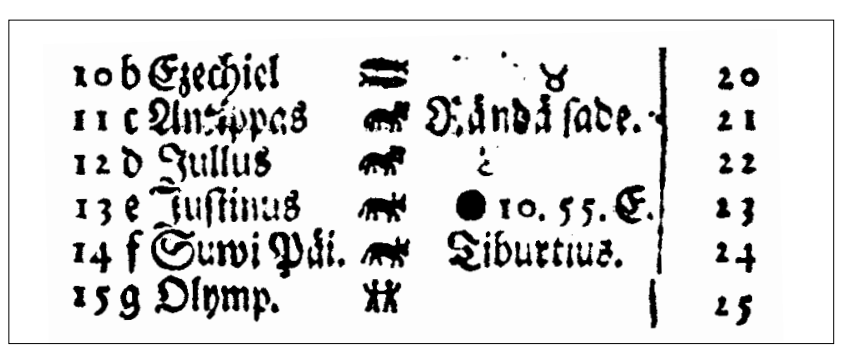

Huhtikuun 14. päivä oli entisaikaan Tiburtiuksen päivä. 1700-luvun alussa almanakassa luki tällä kohdalla "suwi-päiwä". Kuva vuoden 1705 Yliopiston almanakasta. mukaan vesien kylmeneminen alkaa keskimäärin juuri elokuun alussa.

Elokuussa ei nykyajan almanakoissa ole yhtään kirkollista tai edes maallista merkkipäivää. Marjatan päivä 15.8. on kuitenkin muistona vanhasta "Jälki-Mariasta", jota vietettiin Neitsyt Marian kuolinpäivänä. Eniten elokuisia sananparsia liittyy kansan suussa Laurin päivään 10.8 . ja Pertun päivään 24.8. Edellinen on saanut nimensä Pyhästä Laurista, joka kärsi marttyyrikuoleman 200-luvulla, jälkimmäinen apostoli Bartolomeuksesta. Esimerkiksi pääskysten sanotaan kerääntyvän "Lassilta laumaan, Pärttyliltä matkaan". Pertunpäivän aikaan tulee joinain vuosina lämmin jakso, jota sanotaan mm. intiaanikesäksi. Suomen kansa on puhunut Pärttylin pikkukesästä.

Syyskuun 11. päivän, Aleksanterin päivän, iltana vietettiin vanhan ajan työpajoissa pientä silmänkirkastusjuhlaa. Mestari tarjosi kahvit ja ryypyt, ja verstaaseen sytytettiin kesän jälkeen ensimmäisen kerran valot. Syys-lokakuun vaihteessa mikkelinä ajettiin lehmät sisälle navettaan, ja silloin päättyi palkollisten palveluvuosi. He pitivät "runtuviikon" ja siirtyivät ehkä uuteen työpaikkaan.

Lokakuun 7. päivä on nimetty Pyhälle Birgitalle, suomalaisittain Pirkolle. Birgitta perusti Vadstenan luostarin 1300-luvulla, ja kuoltuaan hänet julistettiin pyhimykseksi. Lokakuun 14. päivänä oli entisajan al-

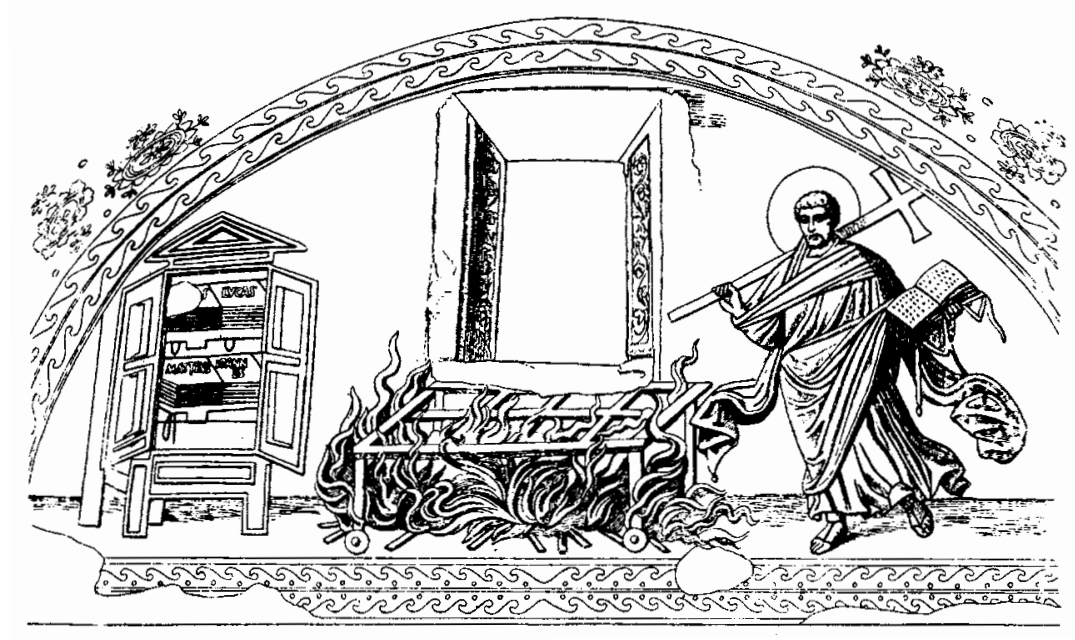

Alkuperäinen Lauri eli Pyhä Laurentius kuvattuna ravennalaisessa mosaiikissa 400luvulla. 
manakoissa merkintä "Calixtus eli Talwi-Päiwä". Kesäpuoli vuotta vaihtui talveksi. Viikkoa ensimmäisen talvipäivän jälkeen oli "oravan päivä", jolloin sopi ruveta keräämän tuon ajan rahaa, oravannahkoja.

Loka-marraskuun taitteessa vietettiin ennen vuodenvaihdetta, jakoaikaa. Vuoden työt oli tehty, sadot korjattu, ja voitiin hetkeksi rauhoittua Monet jakoajan ja vuoden viimeisen päivän, kekrin eli köyrin, tavat ovat siirtyneet nykyiseen jouluun ja uuteenvuoteen. Entisen suomalaisen kekrin paikalle tuli katolisen kirkon kautta pyhäinpäivä.

Marraskuun 10:ntenä, Martin päivänä, on ennen vanhaan syöty ja juotu runsaasti: verimakkaroita, rasvarieskoja ja olutta tai hienommin martinhanhea ja viiniä. 10. tai 11.11 . on muisteltu itse asiassa kolmea tämännimistä henkilöä: Martti-paavia (k. noin 650), Martti Lutheria (s. 1483) ja vanhempaa Martti-piispaa (300-luvulla).

Kaisan päivänä (25.11.) kerittiin lampaat ja myös herkuteltiin lampaanlihalla.

Annan päivä oli alkuaan 15. joulukuuta, mutta nykyään se on 9.12. Anna oli Neitsyt Marian äiti, joka on meillä suomalaistunut Anniksi ja Annikiksi. Lucianpäivää vietetään varsinkin suomenruotsalaisten keskuudessa keskiviikkona 13.12. Päiväkotien ja koulujen kautta päivä on muodostumassa myös suomalaisten juhlaksi. Tuomaan päivää 21.12. on vanhastaan pidetty joulun alkuna. Ja Sylvester (31.12.) onkin jo uuden vuoden aatto. Virossa päivän nimenä on vana-aasta (vanhavuosi).

\section{Nimipäivät}

Almanakkojen suosituinta luettavaa ovat maassamme nimipäivät. Euroopan maista Suomen lisäksi vain Ruotsissa, Unkarissa, Tšekissä ja Latviassa on vastaava, ajan tasalla oleva ei-kirkollinen nimipäiväkalenteri ja nimipäiväperinne. Lisäksi Euroopan katolisissa maissa, esim. Puolassa, Kreikassa ja Kroatiassa, juhlitaan kunkin henkilön omaa nimipäiväpyhimystä.

Euroopan ulkopuolella nimipäivä on useimmissa maissa ja kulttuureissa tuntematon käsite. Kaikissa maissa on tietysti omat nimipäivänsä, mutta nimet eivät ole yleensä sidoksissa mihinkään päivämäärään.

Suomalainen nimipäiväluettelo on kehittynyt vanhasta kirkollisesta pyhimyskalenterista, jota julkaistiin meikäläisissä almanakoissa 1600luvulta alkaen. Pyhimysten rinnalle nousi aluksi raamatullisia nimiä,

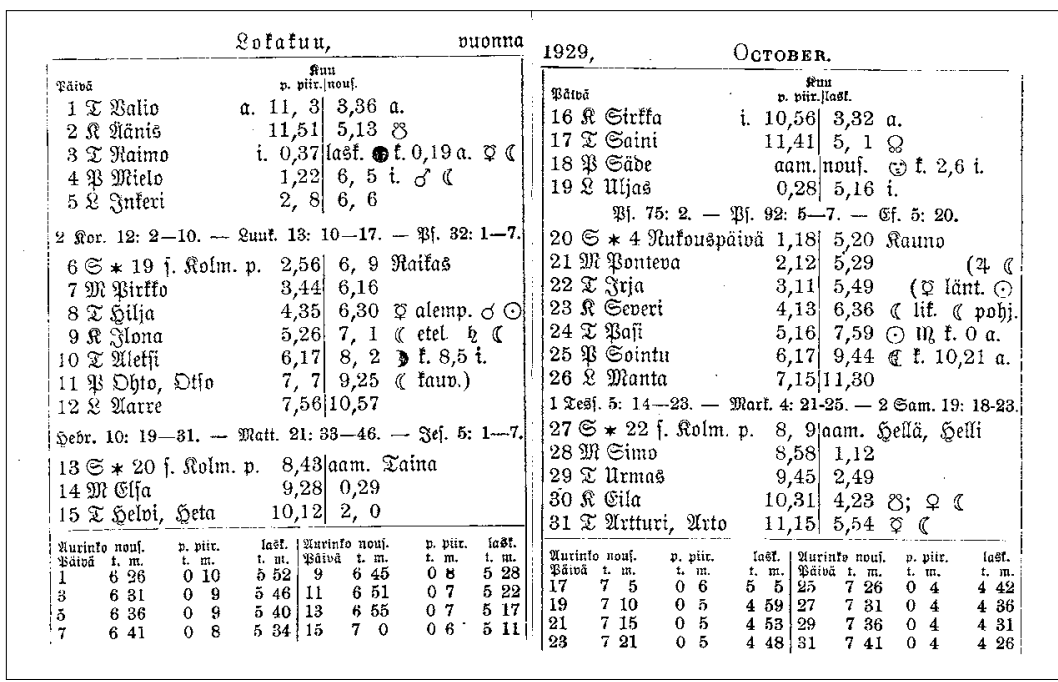

Yliopiston almanakan nimiluettelo oli suomalaisimmillaan vuonna 1929. Lokakuun päivänsankareita olivat mm. Valio, Äänis, Raikas ja Ponteva.

kuten Mooses tai Hanna, ja sitten kansainvälisiä muotinimiä tai kuningas- ja keisarihuoneen nimiä, kuten Ulla tai Eleonoora.

Sivujen 215-229 taulukoissa on merkittynä suomalaisen almanakan nimipäivät sadan vuoden välein 1700-luvun alusta nykypäivään. Kuten nähdään, 1700- ja 1800-luvun alkujen listat ovat hyvin samankaltaiset.

Omaan suuntaan suomalainen nimiluettelo lähti kehittymään 1800luvun loppupuoliskolla kansallisuusaatteen vahvistuessa. Omakielisten nimien käytöllä Suomessa haluttiin tehdä pesäeroa silloiseen emämaahan Venäjään. Nimistöä uusittiin varovasti 1890 ja 1909, mutta vasta Suomen itsenäistyttyä tehtiin nimipäiväluettelossa suurremontti.

Vuoteen 1929 asti oli Suomessa suomen- ja ruotsinkielisillä yksi yhteinen nimipäiväluettelo, jossa vain nimien kirjoitustapa oli eri kielissä hieman erilainen. Vuonna 1929 erotettiin suomenkielinen ja ruotsinkielinen nimipäiväluettelo toisistaan. Näin saatiin tilaa suurelle joukolle uusia suomalaisnimiä.

Seuraavan kerran nimipäiväluetteloa uusittiin 1950 ja 1973. Tämän jälkeen saatiin nykyaikainen tietojenkäsittelytekniikka mukaan nimiluettelon uudistustyöhön, kun aikaisemmin oli uudistusten taustalla vain rajoitettuja tilastoja ja "näppituntumaa". Helsingin yliopisto osti 
1980 Väestörekisterikeskukselta tiedot kaikista vuoden 1880 jälkeen annetuista nimistä eli yli kymmenestä miljoonasta nimestä.

Tietojen perusteella voitiin ensimmäisen kerran laskea yleisyysluvut jokaisesta suomalaisnimestä, ja 1980-luvulta alkaen on uusia nimiä kalenteriin valittaessa voitu katsoa suoraan, paljonko kutakin nimeä on lapselle annettu.

Nimipäiväluetteloa uusittiin 1984 ja 1995, ja sen jälkeen tarkistus on tehty viiden vuoden välein, viimeksi 2010 . Seuraava uudistus on edessä vuoden 2015 kalentereissa.

Nimipäiväluettelon ylläpitäminen on Suomessa Helsingin yliopiston vastuulla. Vuoteen 1995 asti oli Helsingin yliopistolla yksinoikeus suomen- ja ruotsinkielisten kalenterien julkaisemiseen, joten oli luonnollista, että yliopisto hoiti myös nimiluetteloa. Almanakkaerioikeus kumottiin Suomen liittyessä Euroopan unioniin, mutta Helsingin yliopiston suomen kielen laitos jatkaa edelleen nimipäiväluettelon ylläpitoa.

Vuoden 1950 ja 1973 uudistukset olivat professori Kustaa Vilkunan käsialaa, ja vuosina 1980-2009 nimiluettelosta huolehti professori Eero

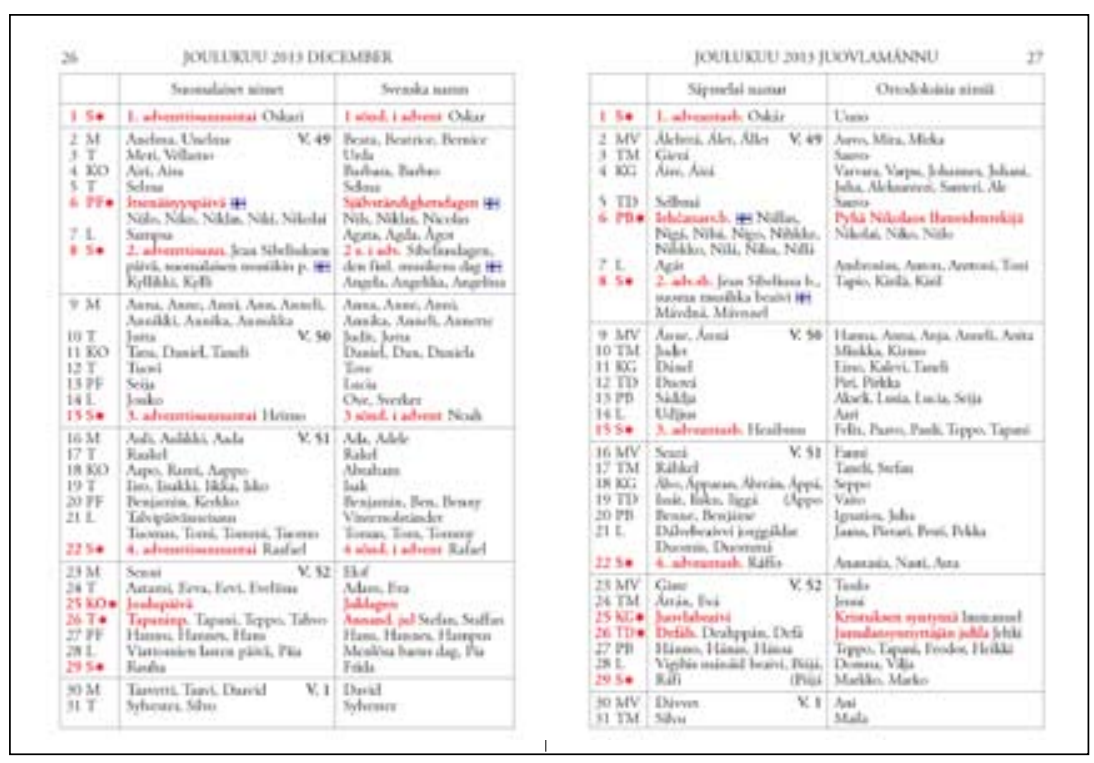

Yliopiston nimipäiväalmanakka luettelee Suomen kaikki neljä nimipäiväluetteloa. Nimipäiväalmanakka ilmestyy nykyään verkossa almanakkatoimiston nimisivuilla osoitteessa http://almanakka.helsinki.fi/nimipaivat.
Kiviniemi. Vuoden 2010 nimiuudistuksen Eero Kiviniemi valmisteli yhdessä dosentti Minna Saarelma-Paukkalan kanssa, ja vuoden 2010 alusta lähtien Saarelma-Paukkala vastaa maamme kalenterien suomenkielisestä nimipäiväluettelosta.

Suomenkielisen luettelon rinnalla on maassamme tätänykyä käytössä kolme muutakin nimipäiväluetteloa. Suomenruotsalaista luetteloa on uusittu samoina aikoina kuin suomalaista, ja luettelosta on huolehtinut professori Marianne Blomqvist.

Vuonna 1996 valmistui saamenkielinen nimiluettelo, jonka laati professori Pekka Sammallahti Oulun yliopiston suomen ja saamen kielen laitoksesta. Saamelainen luettelo herätti myönteistä huomiota muissa pohjoismaissa. Norjalaistutkija Håkan Rydving arvioi julkaisussaan, että "saamelaiset nimet saavat ensimmäisen kerran tasavertaisen aseman suomalaisten ja ruotsalaisten nimien rinnalla. Ei ole liioittelua sanoa, että luettelon julkaiseminen on huomattava kulttuurisaavutus."

Maamme neljäs luettelo kattaa ortodoksiset nimet, ja sitä ylläpitää Ortodoksisen kirjallisuuden julkaisuneuvosto. Kaikkien neljän luettelon mukaiset nimet julkaistaan vuosittain ilmestyvässä Yliopiston nimipäiväalmanakassa (http://almanakka.helsinki.fi/nimipaivat). 


\begin{tabular}{|c|c|c|c|}
\hline \multicolumn{4}{|c|}{ TAMMIKUU } \\
\hline$\underline{1700}$ & 1800 & 1900 & $\underline{2000}$ \\
\hline 1. Nyåhrsdag & Uud. Wuod. p. & Uud. w. p. & Uudenvuodenpäivä \\
\hline 2. Abel, Seth & Abel, Seth & Aapel, Set & Aapeli \\
\hline 3. Matusal. & Enoch & Eenokki & Elmeri, Elmer, Elmo \\
\hline 4. Enoch & Titus & Tiitus & Ruut \\
\hline 5. Simeon & Simeon & Simeon & Lea, Leea \\
\hline 6. Trett. dag & Loppiainen & Loppiainen & Loppiainen, Harri \\
\hline 7. Lucianus & Lucianus & Aukusti & Aukusti, Aku, August \\
\hline 8. Erhardus & Erhard & Erhard & Hilppa, Titta \\
\hline 9. Beatus & Julianus & Julian & Veikko, Veli, Veijo \\
\hline 10. Paul. Erem. & Nicanor & Nikanor & Nyyrikki \\
\hline 11. Hyginus & Hyginus & Hyginus & Kari, Karri \\
\hline 12. Reinhold & Arcadius & Arkadius & Toini \\
\hline 13. Hilarius & Knut & Nuutti & Nuutti \\
\hline 14. Maurus & Felix & Feeliks & Sakari, Saku \\
\hline 15. Felix & Maurus & Mauri & Solja \\
\hline 16. Marcellus & Marcellus & Marcellus & Ilmari, Ilmo \\
\hline 17. Antonius & Antonius & Antti & $\begin{array}{l}\text { Toni, Anttoni, Antto, } \\
\text { Anton }\end{array}$ \\
\hline 18. Prisca & Prisca & Priska & Laura \\
\hline 19. Henric & Henrik. & Heikki & $\begin{array}{l}\text { Heikki, Henrik, Henrikki, } \\
\text { Henri }\end{array}$ \\
\hline 20. Fab. Seb. & Fabian & Faabian & Henna, Henni, Henriikka \\
\hline 21. Vincent. & Agneta & Agneeta & Aune, Oona, Auni \\
\hline 22. Agneta & Vincentius & Vincentius & Visa \\
\hline 23. Emerentia & Emerentia & Emerentia & Eine, Eini, Enni \\
\hline 24. Timothe. & Eric Transl. & Erkki Translatus & Senja \\
\hline 25. Pauli Om. & Paulus & Paavali & Paavo, Pauli, Paavali, Paul \\
\hline 26. Polycarp. & Polycarpus & Polykarpus & Joonatan \\
\hline 27. Chrysost. & Chrysostomus & Krysostomus & Viljo \\
\hline 28. Valerius & CARL & Kaarlo & Kaarlo, Kalle, Kaarle, Mies \\
\hline 29. CAROLUS & Wallerius & Walerius & Valtteri \\
\hline 30. Adelgund & Gunnila & Gunilla & Irja \\
\hline 31. Virgilius & Wigilius & Alli & Alli \\
\hline
\end{tabular}

\begin{tabular}{|c|c|c|c|c|}
\hline \multicolumn{5}{|c|}{ HELMIKUU } \\
\hline & 1700 & 1800 & 1900 & $\underline{2000}$ \\
\hline 1. & Brigitta & Brigitta & Pirkko & Riitta \\
\hline 2. & Kyndermes. & Kyntilän Päiwä & Maar kirk. k. & Aamu, Jemina \\
\hline 3. & Blasius & Blasius & Huugo & Valo \\
\hline 4. & Veronica & Ansgarius & Ansgarius & Armi, Ronja \\
\hline 5. & Agatha & Agatha & Agaata & Asser \\
\hline 6. & Dorothea & Dorothea & Dorotea & $\begin{array}{l}\text { Terhi, Teija, Tiia, Tea, } \\
\text { Terhikki }\end{array}$ \\
\hline 7. & Richard & Richard & Rikard & Riku, Rikhard \\
\hline 8. & Salomon & Malachias & Malakias & Laina \\
\hline 9. & Apollonia & Apollonia & Naima & Raija, Raisa \\
\hline 10. & Scholasti. & Scholastica & Eliina & Elina, Elna, Ella, Ellen \\
\hline 11. & Euphrasia & Euphrosyne & Eufrosyne & Talvikki \\
\hline 12. & Eulalia & Eulalia & Eulaalia & Elma, Elmi \\
\hline 13. & Agabus & Agabus & Agabus & Sulo, Sulho \\
\hline 14. & Vallentin. & Wallentin & Valentin & Voitto, Valentin, Tino \\
\hline 15. & Sigfrid & Sigfrid & Sipi & Sipi, Sippo \\
\hline 16. & Juliana & Juliana & Juliana & Kai \\
\hline 17. & Alerand. & Polychron & Polykron & Väinö, Väinämö \\
\hline 18. & Concordia & Concordia & Konkordia & Kaino \\
\hline 19. & Susanna & Gabinus & Gabinus & Eija \\
\hline 20. & Eucharius & Eucharius & Eukarius & Heli, Helinä, Heljä, Hely \\
\hline 21. & Esaias & Hilarius & Hilarius & Keijo \\
\hline 22. & Pet. Cathed. & Petr. Cathedr. & Pietari Kathedra & Tuulikki, Tuuli, Tuulia \\
\hline 23. & Gerhard & Tertullianus & Tertullian & Aslak \\
\hline 24. & Matthias & Matthias & Mattias & Matti, Matias \\
\hline 25. & Victoria & Viktorinus & Viktorina & Tuija, Tuire \\
\hline 26. & Nestor & Nestor & Nestor & Nestori \\
\hline 27. & Leander & Leander & Leander & Torsti \\
\hline 28. & Romanus & Macharius & Makarius & Onni \\
\hline 29. & & & & Karkauspäivä \\
\hline
\end{tabular}




\begin{tabular}{|c|c|c|c|}
\hline \multicolumn{4}{|c|}{ MAALISKUU } \\
\hline 1700 & $\underline{1800}$ & 1900 & $\underline{2000}$ \\
\hline 1. Albinius & Albin & Albinus & Alpo, Alvi, Alpi \\
\hline 2. Simplicius & Simplicius & Fanny & Virve, Virva \\
\hline 3. Ariana & Cunigunda & Kunigunda & Kauko \\
\hline 4. Adrianus & Adrian & Adrian & Ari, Arsi, Atro \\
\hline 5. Fredrich & Conon & Konon & Laila, Leila \\
\hline 6. Victoria & Fulgentius & Ruudolf & Tarmo \\
\hline 7. Perpetua & Perpetua & Perpetua & Tarja, Taru \\
\hline 8. Philemon & Philemon & Filemon & Vilppu \\
\hline 9. 40 Martyr. & 40 Martyriä & 40 Martyria & Auvo \\
\hline 10. Cajus & Apollonius & Auroora & Aurora, Aura, Auri \\
\hline 11. Constant. & Windician & Vindician & Kalervo \\
\hline 12. Gregorius & Gregorius & Gregorius & Reijo, Reko \\
\hline 13. Ernest & Nicephorus & Nikeforus & Erno, Tarvo, Ernesti \\
\hline 14. Zacharias & Mathilda & Matilda & Matilda, Tilda \\
\hline 15. Longinus & Christopher & Kristofer & Risto \\
\hline 16. Gabriel & Heribert & Heribert & Ilkka \\
\hline 17. Gertrud & Gertrud & Kerttu & Kerttu, Kerttuli \\
\hline 18. Alexander & Edward & Eedward & Eetu, Edvard \\
\hline 19. Josephus & Joseph & Jooseppi & $\begin{array}{l}\text { Jooseppi, Juuso, Joosef, } \\
\text { Josefiina }\end{array}$ \\
\hline 20. Rubertus & Joachim & Jaakkima & $\begin{array}{l}\text { Aki, Joakim, Kim, } \\
\text { Jakkima }\end{array}$ \\
\hline 21. Benedicht. & Benedictus & Pentti & Pentti \\
\hline 22. Casimirus & Victor & Viktor & Vihtori \\
\hline 23. Theodorus & Axel & Akseli & Akseli \\
\hline 24. Rosina & Gabriel & Gaabriel & $\begin{array}{l}\text { Kaapo, Gabriel, Kaapro, } \\
\text { Kaappo }\end{array}$ \\
\hline 25. Maria beb. & Mar. Ilm. P. & Maar. Ilm. p. & Aija \\
\hline 26. Emanuel & Emanuel & Immanuel & $\begin{array}{l}\text { Manu, Immanuel, Manne, } \\
\text { Immo }\end{array}$ \\
\hline 27. Gustavus & Rupert & Ruupert & Sauli, Saul \\
\hline 28. Malchus & Malcus & Malkus & Armas \\
\hline 29. Gideon & Jonas & Jonas & $\begin{array}{l}\text { Joonas, Jouni, Joni, Joona, } \\
\text { Jonne, Jonni }\end{array}$ \\
\hline 30. Ananias & Qwirinus & Guido & Usko \\
\hline 31. Adonias & Amos & Amos & Irma, Irmeli \\
\hline
\end{tabular}

\begin{tabular}{|c|c|c|c|}
\hline \multicolumn{4}{|c|}{ HUHTIKUU } \\
\hline$\underline{1700}$ & 1800 & 1900 & $\underline{2000}$ \\
\hline 1. Theodorus & Harald & Haarald & Raita, Pulmu \\
\hline 2. Ferdinad. & Theodosius & Teodosius & Pellervo \\
\hline 3. Ulpianus & Ferdinand & Ferdinand & Sampo \\
\hline 4. Ambrosius & Ambrosius & Ambrosius & Ukko \\
\hline 5. Maximilian & Irenes & Ireene & Irene, Irina, Ira, Iro \\
\hline 6. Moses & Wilhelm & Wilho & $\begin{array}{l}\text { Vilho, Ville, Viljami, } \\
\text { Vilhelm, Vili, Jami }\end{array}$ \\
\hline 7. Egesippus & Hegesippus & Hegesippus & Allan, Ahvo \\
\hline 8. Dionysius & Perpetuus & Perpetuus & Suoma, Suometar \\
\hline 9. Hiob & Otto & Otto & Elias, Eelis, Eljas \\
\hline 10. Ezechiel & Hezechiel & Hesekiel & Tero \\
\hline 11. Leo & Antipas & Antipas & Verna \\
\hline 12. Julius & Julius & Julius & Julius, Julia, Juliaana \\
\hline 13. Justinus & Justinus & Justinus & Tellervo \\
\hline 14. Tiburtius & Tiburtius & Tiburtius & Taito \\
\hline 15. Eutyches & Olympias & Olympias & Linda, Tuomi \\
\hline 16. Calixtus & Patrick & Patrik & Jalo, Patrik \\
\hline 17. Rudolph. & Elias & Eljas & Otto \\
\hline 18. Valerius & Walerian & Valerian & Valto, Valdemar \\
\hline 19. Timon. & Bernhard & Bernhard & Pälvi, Pilvi \\
\hline 20. Hermog. & Amalia & Amalia & Lauha \\
\hline 21. Anhelmus & Anshelm & Anselm & Anssi, Anselmi \\
\hline 22. Ertwin & Gotherius & Aliina & Alina \\
\hline 23. Georgius & Georgius & Yrjö & Yrjö, Jyrki, Jyri, Yrjänä, Jori \\
\hline 24. Longinus & Albertina & Albertiina & Pertti, Albert, Altti \\
\hline 25. Marcus & Marcus & Markus & Markku, Markus, Marko \\
\hline 26. Joel & Cletus & Kleetus & Terttu, Teresa \\
\hline 27. Anastasius & Antimus & Antimus & Merja \\
\hline 28. Theodora & Thure & Tuure & Ilpo, Ilppo, Tuure \\
\hline 29. Germanus & Tycho & Tyko & Teijo \\
\hline 30. Sewerus & Marianus & Marianna & $\begin{array}{l}\text { Mirja, Mirva, Mira, Miia, } \\
\text { Mirjami, Mirka, Mirkka }\end{array}$ \\
\hline
\end{tabular}




\begin{tabular}{|c|c|c|c|}
\hline \multicolumn{4}{|c|}{ TOUKOKUU } \\
\hline 1700 & 1800 & 1900 & $\underline{2000}$ \\
\hline 1. Philip., Jac. & Philippus & Wappu & Vappu, Valpuri \\
\hline 2. Sigismund & Athanasius & Atanasius & Vuokko, Viivi \\
\hline 3. Korsmessa & Ristin-Päiw. & Ristinpäivä & Outi \\
\hline 4. Gothard. & Monica & Roosa & Ruusu, Roosa \\
\hline 5. Lysander & Gotthard & Gotthard & Maini \\
\hline 6. Protogen. & Sigismund & Aleksandra & Ylermi \\
\hline 7. Domicilla & Stanislaus & Stanislaus & Helmi, Kastehelmi \\
\hline 8. Stanislaus & Achatius & Agda & Heino \\
\hline 9. Hermes & Timotheus & Timoteus & Timo \\
\hline 10. Epimachus & Epimachus & Aina & Aino, Aina, Aini, Ainikki \\
\hline 11. Pancrati & Mamertus & Mamertus & Osmo \\
\hline 12. Gordian & Charlotta & Lotta & Lotta \\
\hline 13. Theophil. & Serwatius & Floora & Kukka, Floora \\
\hline 14. Christiern. & Corona & Ediita & Tuula \\
\hline 15. Sophia & Sophia & Sofia & Sofia, Sonja, Sohvi \\
\hline 16. Sara & Peregrinus & Ester & Esteri, Essi, Ester \\
\hline 17. Jodocus & Rebecca & Rebekka & $\begin{array}{l}\text { Maila, Maili, Mailis, } \\
\text { Rebekka }\end{array}$ \\
\hline 18. Ericus & Eric & Erkki & Erkki, Eero, Eerikki, Eerika \\
\hline 19. Potentia & Potentia & Emilia & $\begin{array}{l}\text { Emilia, Emma, Emmi, } \\
\text { Milla, Milja, Milka, Amalia }\end{array}$ \\
\hline 20. Bernhard. & Carolina & Karoliina & Lilja, Karoliina, Lilli \\
\hline 21. Sibylla & Constantin & Kosti & Kosti, Konsta, Konstantin \\
\hline 22. Prudens & Henning & Hemminki & Hemminki, Hemmo \\
\hline 23. Desiderius & Desiderius & Lyydi & Lyydia, Lyyli \\
\hline 24. Ester & Rogatius & Alarik & Tuukka, Touko \\
\hline 25. Urbanus & Urban & Urpo & Urpo \\
\hline 26. Desiderius & Wilhelmina & Wilhelmina & $\begin{array}{l}\text { Vilhelmiina, Minna, } \\
\text { Vilma, Miina, Mimmi }\end{array}$ \\
\hline 27. Rudolphus & Beda & Beeda & Ritva \\
\hline 28. Wilhelm & Germanus & Germanus & Alma \\
\hline 29. Maximin. & Maximinus & Maksiminus & Oiva, Oivi, Olivia \\
\hline 30. Felix & Basilius & Basilius & Pasi \\
\hline 31. Petronella & Petronella & Petronella & Helka, Helga \\
\hline
\end{tabular}

\begin{tabular}{|c|c|c|c|}
\hline \multicolumn{4}{|c|}{ KESÄKUU } \\
\hline$\underline{1700}$ & $\underline{1800}$ & 1900 & $\underline{\mathbf{2 0 0 0}}$ \\
\hline 1. Nicodemus & Nicodemus & Nikodemus & Teemu, Nikodemus \\
\hline 2. Gottskalck & Erasmus & Wenla & Venla \\
\hline 3. Marcellus & Marcellinus & Viola & Orvokki, Viola \\
\hline 4. Erasmus & Optatus & Optatus & Toivo \\
\hline 5. Bonifacius & Bonifacius & Bonifacius & Sulevi \\
\hline 6. Benjamin & Gustaf & Kustaa & Kustaa, Kyösti, Kustavi \\
\hline 7. Lucretia & Robert & Robert & Suvi, Robert, Roope \\
\hline 8. Medardus & Salomon & Salomon & Salomo, Salomon \\
\hline 9. Felicianus & Primus & Primus & Ensio \\
\hline 10. Basilides & Swante & Swante & Seppo \\
\hline 11. Barnabas & Barnabas & Barnabas & Impi, Immi \\
\hline 12. Eschillus & Esfil & Esko & Esko \\
\hline 13. Antonius & Aqwilina & Eedla & Raili, Raila \\
\hline 14. Elisaeus & Elisa & Eliisa & Kielo \\
\hline 15. Vitus & Witus & Wietti & Vieno, Viena \\
\hline 16. Justina & Justina & Justiina & Päivi, Päivikki, Päivä \\
\hline 17. Botolphus & Botolf & Botolf & Urho \\
\hline 18. Homerus & Leontius & Leontius & Tapio \\
\hline 19. Gerwasius & Gerwasius & Siiri & Siiri \\
\hline 20. Florentia & Florentin & Florentin & Into \\
\hline 21. Rachel & Albanus & Albanus & Ahti, Ahto \\
\hline 22. 10000 Mart. & Paulinus & Paulinus & Paula, Liina, Pauliina \\
\hline 23. Beata & Adolph & Aatto & Aatto, Aatu, Aadolf \\
\hline 24. Joh. Bapt. & Joh. Kast. p. & Joh. Kast. p. & $\begin{array}{l}\text { Johannes, Juhani, Juha, } \\
\text { Juho, Jukka, Jussi, Janne, } \\
\text { Jani, Juhana }\end{array}$ \\
\hline 25. Elogius & Dawid & Taawetti & Uuno \\
\hline 26. Jeremias & Jeremias & Jeremias & $\begin{array}{l}\text { Jorma, Jarmo, Jarkko, } \\
\text { Jarno, Jere, Jeremias }\end{array}$ \\
\hline 27. 7. Sofware & Crescens & Elviira & Elviira, Elvi \\
\hline 28. Leo Papa & Leo & Leo & Leo \\
\hline 29. Pet., Paul. & Petrus & Pietari & $\begin{array}{l}\text { Pietari, Pekka, Petri, Petra, } \\
\text { Petteri, Pekko }\end{array}$ \\
\hline 30. Lucina & Martialis & Martialis & Päiviö, Päivö \\
\hline
\end{tabular}




\begin{tabular}{|c|c|c|c|}
\hline \multicolumn{4}{|c|}{ HEINÄKUU } \\
\hline$\underline{1700}$ & 1800 & 1900 & $\underline{2000}$ \\
\hline 1. Theobald. & Aron & Aaro & Aaro, Aaron \\
\hline 2. Marias Bes. & Marian Etsik.p. & Maar. ets. & $\begin{array}{l}\text { Maria, Mari, Maija, Meeri, } \\
\text { Maaria, Marika, Maiju, } \\
\text { Maikki, Kukka-Maaria }\end{array}$ \\
\hline 3. Cornelius & Anatolius & Anatolius & Arvo \\
\hline 4. Ulricus & Ulrica & Ulla & Ulla, Ulpu \\
\hline 5. Anshelmus & Melker & Melker & Unto, Untamo \\
\hline 6. Hechtor & Esaias & Esaias & Esa, Esaias \\
\hline 7. Claudius & Claes & Klaus & Klaus, Launo \\
\hline 8. Chilianus & Kilian & Kilian & Turo, Turkka \\
\hline 9. Cyrillus & Cyrillus & Kyrillus & Ilta, Jasmin \\
\hline 10. Israel & Canutus & Kanutus & Saima, Saimi \\
\hline 11. Eleonora & Eleonora & Eleonoora & Elli, Noora, Nelli, Eleonoora \\
\hline 12. Arvidus & Herman & Herman & Hermanni, Herkko, Herman \\
\hline 13. Elias & Joel & Joel & Ilari, Lari, Joel \\
\hline 14. Ingrid & Phocas & Aliisa & Aliisa \\
\hline 15. Apost. del. & Apost. Jako & Apost. jak. & Rauni, Rauna \\
\hline 16. Ruth & Reinhold & Reinhold & Reino \\
\hline 17. Alexius & Alexius & Aleksi & Ossi, Ossian \\
\hline 18. Rosina & Fredric & Freedrik & Riikka \\
\hline 19. Ruffina & Sara & Saara & Saara, Sari, Salli, Salla, Sara \\
\hline 20. Margareta & Margaretha & Margareta & $\begin{array}{l}\text { Marketta, Maarit, Reeta, } \\
\text { Maaret, Reetta, Margareeta }\end{array}$ \\
\hline 21. Praxedes & Johanna & Johanna & $\begin{array}{l}\text { Johanna, Hanna, Jenni, } \\
\text { Jonna, Jenna, Hannele, } \\
\text { Hanne, Joanna }\end{array}$ \\
\hline 22. Mar. Magdal. & Magdalena & Matleena & Leena, Leeni, Lenita, Matleena \\
\hline 23. Apollinar & Apollonia & Olga & Oili, Olga \\
\hline 24. Christina & Christina & Kirsti & $\begin{array}{l}\text { Kristiina, Kirsti, Tiina, Kirsi, } \\
\text { Krista, Kiia }\end{array}$ \\
\hline 25. Jacobus & Jacobus & Jaakko & Jaakko, Jaakoppi, Jaakob \\
\hline 26. Anna & Martha & Martta & Martta \\
\hline 27. Merta & 7 Unikekoa & 7 Unikekoa & Unikeonpäivä, Heidi \\
\hline 28. Botwid. & Botwid & Botwid & Atso \\
\hline 29. Olaus & Olof & Olawi & Olavi, Olli, Uolevi, Uoti \\
\hline 30. Abdon & Abdon & Eriika & Asta \\
\hline 31. Germund. & Helena & Heleena & Helena, Elena \\
\hline
\end{tabular}

Jaakko viettää nimipäiväänsä edelleen 25.

heinäkuuta, apostoli Jaakob vanhemman muistopäivänä. Kuvassa tammesta veistetty Jaakobin patsas unkarilaisessa kirkossa.

Hieronymus vietti vuoteen 1907 asti nimipäiväänsä syyskuun viimeisenä. Piirros vuodelta 1520
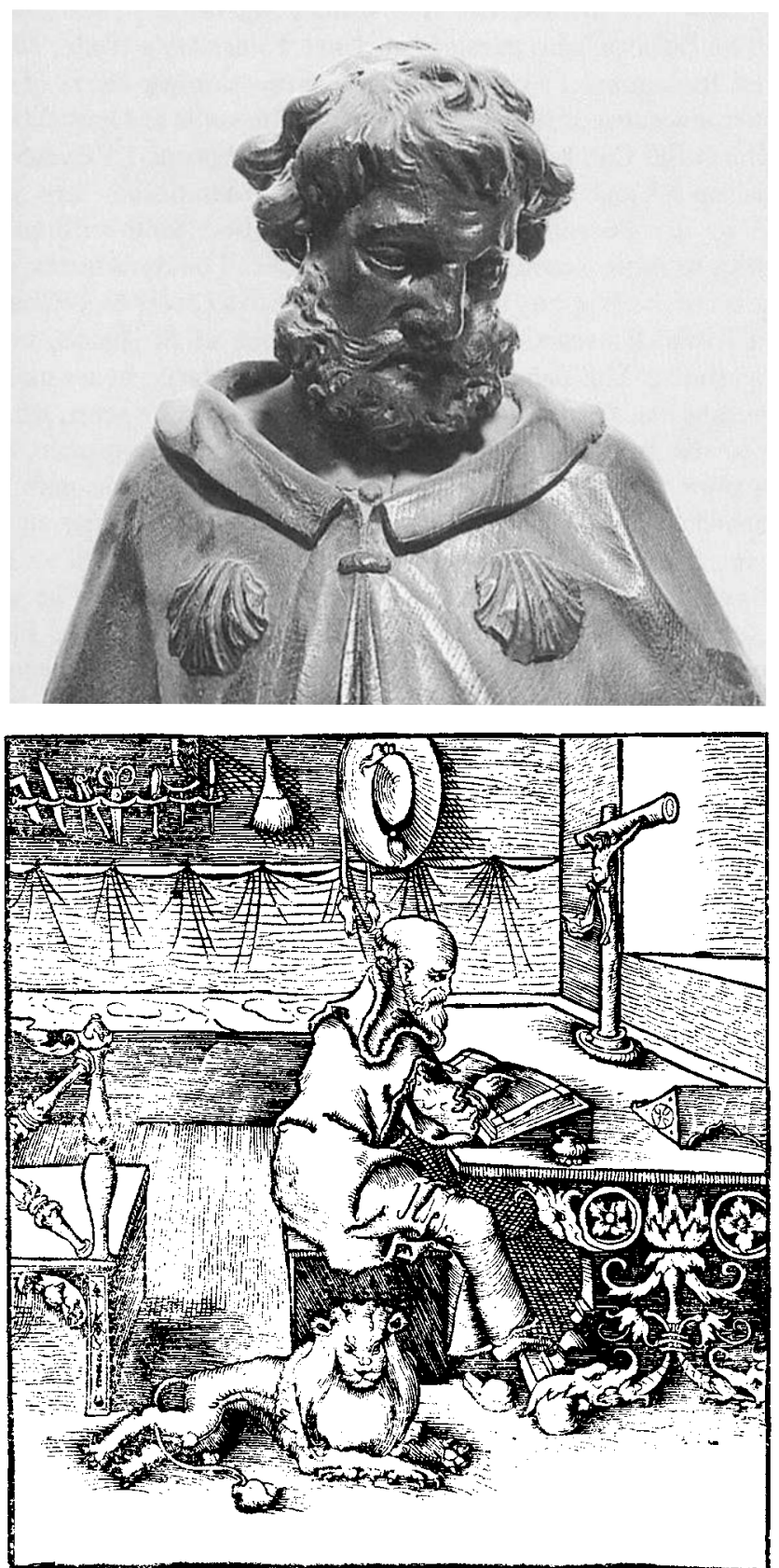


\begin{tabular}{|c|c|c|c|}
\hline \multicolumn{4}{|c|}{ ELOKUU } \\
\hline$\underline{1700}$ & $\underline{1800}$ & 1900 & $\underline{2000}$ \\
\hline 1. Pet. Caten. & Piet. Fang. & Piet. wank. & Maire \\
\hline 2. Eleasar & Catharina & Katri & Kimmo \\
\hline 3. Hanibal & Stephanus & Stefanus & Linnea, Nea, Vanamo \\
\hline 4. Dominicus & Aristarchus & Maria & Veera \\
\hline 5. Donatus & Dominicus & Dominikus & Salme, Sanelma \\
\hline 6. Sixtus & Sixtus & Sikstus & Toimi, Keimo \\
\hline 7. Gunnila & Donatus & Donatus & Lahja \\
\hline 8. Cyriacus & Cyriacus & Cyriakus & Sylvi, Sylvia, Silva \\
\hline 9. Romanus & Romanus & Romanus & Erja, Eira \\
\hline 10. Laurentius & Laurentius & Lauri & Lauri, Lasse, Lassi \\
\hline 11. Susanna & Susanna & Susanna & $\begin{array}{l}\text { Sanna, Sanni, Susanna, } \\
\text { Susanne }\end{array}$ \\
\hline 12. Clara & Clara & Klaara & Klaara \\
\hline 13. Herman & Hippolitus & Hippolytus & Jesse \\
\hline 14. Eusebius & Eusebius & Eusebius & Onerva, Kanerva \\
\hline 15. Eugenius & Jälki-Mar. p. & Jälk. Maar. p. & $\begin{array}{l}\text { Marjatta, Marja, Jaana, } \\
\text { Marjo, Marjut, Marjaana, } \\
\text { Marjukka, Marita, Maritta, } \\
\text { Marianne, Marianna }\end{array}$ \\
\hline 16. Isaacus & Brynolf & Bryynolf & Aulis \\
\hline 17. Helena & Werner & Verner & Verneri \\
\hline 18. Agapitus & Agapetus & Agapetus & Leevi \\
\hline 19. Magnus & Magnus & Mauno & Mauno, Maunu \\
\hline 20. Athanasius & Samuel & Samuli & $\begin{array}{l}\text { Samuli, Sami, Samuel, } \\
\text { Samu }\end{array}$ \\
\hline 21. Samuel & Anastasius & Anastasius & Soini, Veini \\
\hline 22. Sacheus & Symphorian & liwar & livari, livo \\
\hline 23. Simphro. & Zachäus & Sakeus & Varma, Signe \\
\hline 24. Bartholom. & Bartholom. & Bartolomeus & Perttu \\
\hline 25. Ludovicus & Lowisa & Lowiisa & Loviisa \\
\hline 26. Zephyrin & Zephyrinus & Sefyrinus & Ilma, Ilmi, Ilmatar \\
\hline 27. Ireneus & Rufus & Rufus & Rauli \\
\hline 28. Gebhard & Augustinus & Augustinus & Tauno \\
\hline 29. Joh. decol. & Johan Kast. K.I. & Joh. Kast. k. I. & lines, lina, Inari \\
\hline 30. Benjamin & Adaucius & Eemil & Eemil, Eemeli \\
\hline 31. Rebecca & Arwid & Arwi & Arvi \\
\hline
\end{tabular}

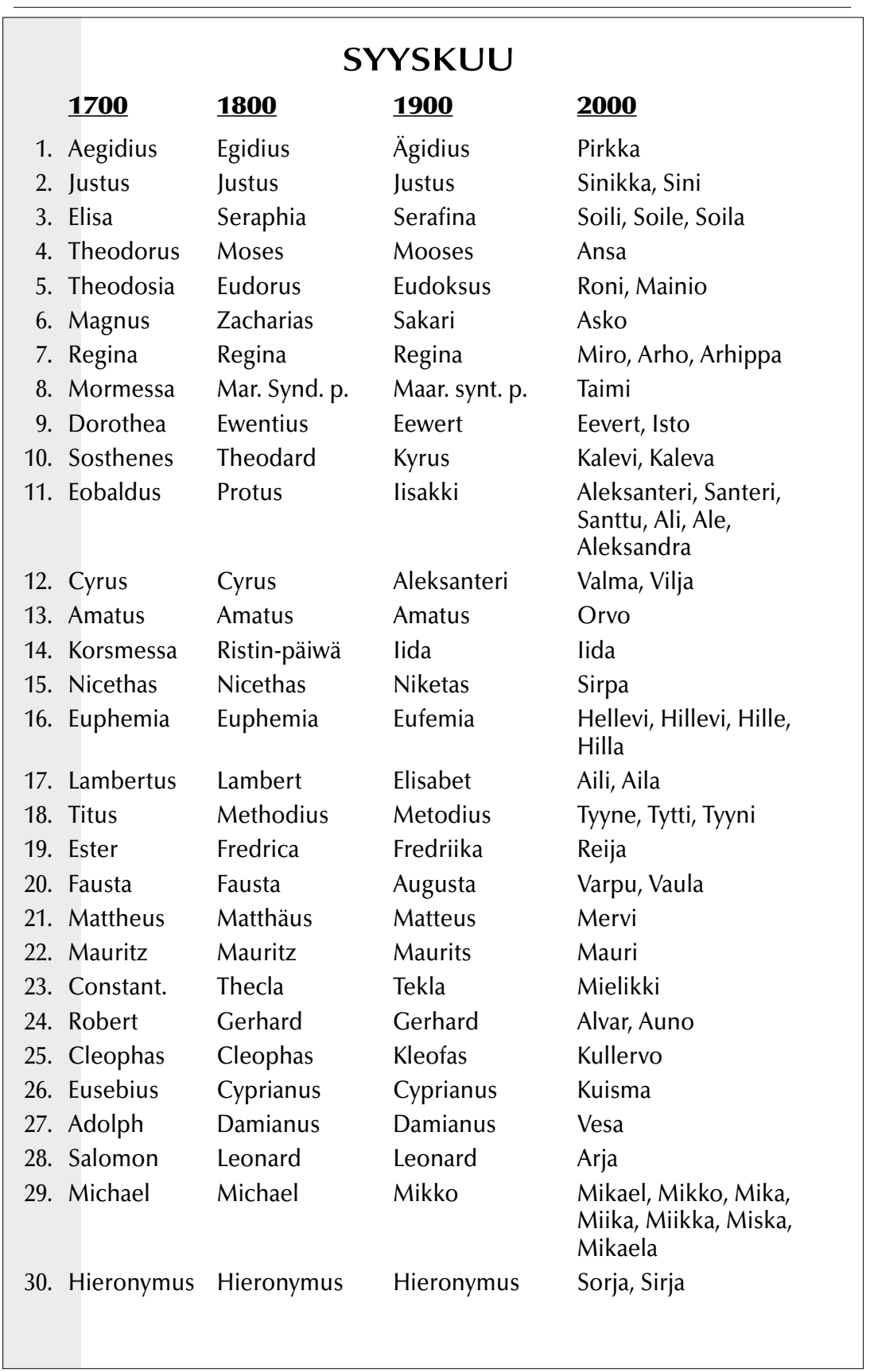




\begin{tabular}{|c|c|c|c|c|}
\hline \multicolumn{5}{|c|}{ LOKAKUU } \\
\hline & $\underline{1700}$ & $\underline{1800}$ & 1900 & $\underline{2000}$ \\
\hline 1. & Remigius & Remigius & Remigius & $\begin{array}{l}\text { Rauno, Rainer, Raine, } \\
\text { Raino }\end{array}$ \\
\hline & Theophius & Ludwig & Ludwik & Valio \\
\hline 3. & Leonhardt & Ewald & Ewald & Raimo \\
\hline 4. & Franciscus & Franciscus & Frans & Saila, Saija \\
\hline 5. & Placidus & Placidus & Inkeri & Inkeri, Inka \\
\hline & Esfillus & Bruno & Bruuno & Minttu, Pinja \\
\hline & Brigitta & Brigitta & Birgitta & $\begin{array}{l}\text { Pirkko, Pirjo, Piritta, Pirita, } \\
\text { Birgitta }\end{array}$ \\
\hline & Charitas & Demetrius & Demetrius & Hilja \\
\hline & Dionysius & Dionysius & Dionysius & Ilona \\
\hline & Gideon & Gereon & Josefiina & Aleksi, Aleksis \\
\hline & Buckhard & Probus & Probus & Otso, Ohto \\
\hline & Maximil. & Walfrid & Walfrid & Aarre, Aarto \\
\hline & Angelus & Theophilus & Teofilus & Taina, Tanja, Taija \\
\hline 14. & Calixtus & Calixtus & Elsa & Elsa, Else, Elsi \\
\hline 15. & Hedewig & Hedvig & Heta & Helvi, Heta \\
\hline & Gallus & Gallus & Gallus & Sirkka, Sirkku \\
\hline 17. & Florentia & Lucina & Lucina & Saini, Saana \\
\hline & Luc. Evan. & Lucas & Luukas & Satu, Säde \\
\hline & Ptolomeus & Ptolomeus & Ptolemäus & Uljas \\
\hline & Calixtus & Casper & Kasper & Kauno, Kasperi \\
\hline 21. & $110002^{9}$ & Ursila & Ursula & Ursula \\
\hline & Cordula & Sewerus & Sewerus & $\begin{array}{l}\text { Anja, Anita, Anniina, } \\
\text { Anitta }\end{array}$ \\
\hline & Sewerin & Sewerin & Seweri & Severi \\
\hline & Natanael & Ewergistus & Ewergistus & Asmo, Rasmus \\
\hline 25. & Crispinus & Chrispin & Krispinus & Sointu \\
\hline & Amandus & Amandus & Amanda & Amanda, Niina, Manta \\
\hline 27. & Sabina & Sabina & Sabina & Helli, Hellä, Hellin, Helle \\
\hline & Sim. Jud. & Sim. Jud. & Simo, Judas & Simo \\
\hline & Narcissus & Narcissus & Narcissus & Alfred, Urmas \\
\hline 30. & Absalon & Zenobia & Gustaawa & Eila \\
\hline & Wolfgang & Qwintinus & Artturi & Artturi, Arto, Arttu \\
\hline
\end{tabular}

\begin{tabular}{|c|c|c|c|}
\hline \multicolumn{4}{|c|}{ MARRASKUU } \\
\hline$\underline{1700}$ & 1800 & $\underline{1900}$ & $\underline{\mathbf{2 0 0 0}}$ \\
\hline 1. All. helgond.. & Pyh. Miest. p. & Pyh. miest. p. & Pyry, Lyly \\
\hline 2. Alle siälar & Tobias & Topias & Topi, Topias \\
\hline 3. Malachias & Eustachius & Erland & Terho \\
\hline 4. Emericus & Amatius & Amatius & Hertta \\
\hline 5. Blandina & Malachias & Malakias & Reima \\
\hline 6. Leonhard & Gust. Adolph & Kustaa Aadolf & Kustaa Aadolf \\
\hline 7. Engelbrecht & Engelbert & Engelbert & Taisto \\
\hline 8. Gottfrid & Willehad & Willehad & Aatos \\
\hline 9. Theodorus & Theodor & Teodor & Teuvo \\
\hline 10. Mart. Luther & Mårten Luther & Mart. Lutherus & Martti \\
\hline 11. Mart. B. & Mart. Pispa & Mart. piispa & Panu \\
\hline 12. Jonas & Conrad & Konrad & Virpi \\
\hline 13. Eugenius & Christian & Kristian & Ano, Kristian \\
\hline 14. Fredrich & Hypatius & Hypatius & liris \\
\hline 15. Leopoldus & Leopold & Leopold & $\begin{array}{l}\text { Janika, Janita, Janina, } \\
\text { Janette }\end{array}$ \\
\hline 16. Ottomarus & Edmund & Edmund & Aarne, Aarno, Aarni \\
\hline 17. Alpheus & Anian & Anian & Eino, Einari \\
\hline 18. Maximus & Maximus & Maksimus & Tenho, Jousia \\
\hline 19. Elisabeth & Elisabeth & Lambert & $\begin{array}{l}\text { Elisabet, Liisa, Eliisa, Elisa, } \\
\text { Elise, Liisi }\end{array}$ \\
\hline 20. Amos & Pontus & Jalmar & Jalmari, Jari \\
\hline 21. Mar. Afl. & Heliodorus & Heliodorus & Hilma \\
\hline 22. Cecilia & Cecilia & Cecilia & Silja, Selja \\
\hline 23. Clemens & Clemens & Klemens & Ismo \\
\hline 24. Belasius & Christogonus & Kristogonus & Lempi, Lemmikki, Sivi \\
\hline 25. Catharina & Catharina & Katriina & $\begin{array}{l}\text { Katri, Kaisa, Kaija, Katja, } \\
\text { Kaarina, Katariina, } \\
\text { Katriina, Kati, Kaisu, Riina }\end{array}$ \\
\hline 26. Conradus & Linus & Dagmar & Sisko \\
\hline 27. Vitalis & Witalis & Vitalis & Hilkka \\
\hline 28. Rufus & Sten & Sten & Heini \\
\hline 29. Eberhard & Sarturninus & Saturninus & Aimo \\
\hline 30. Andreas & Andreas & Antero & Antti, Antero, Atte \\
\hline
\end{tabular}




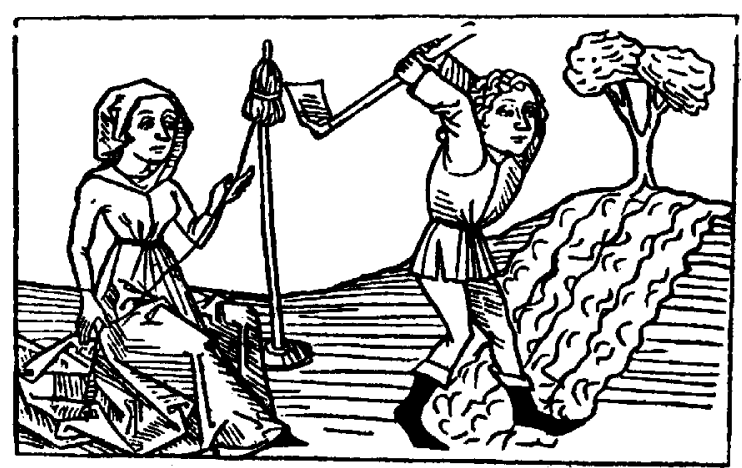
nimipäiväänsä jouluaattona. "Otsa hiessä sinun on hankittava leipäsi..."

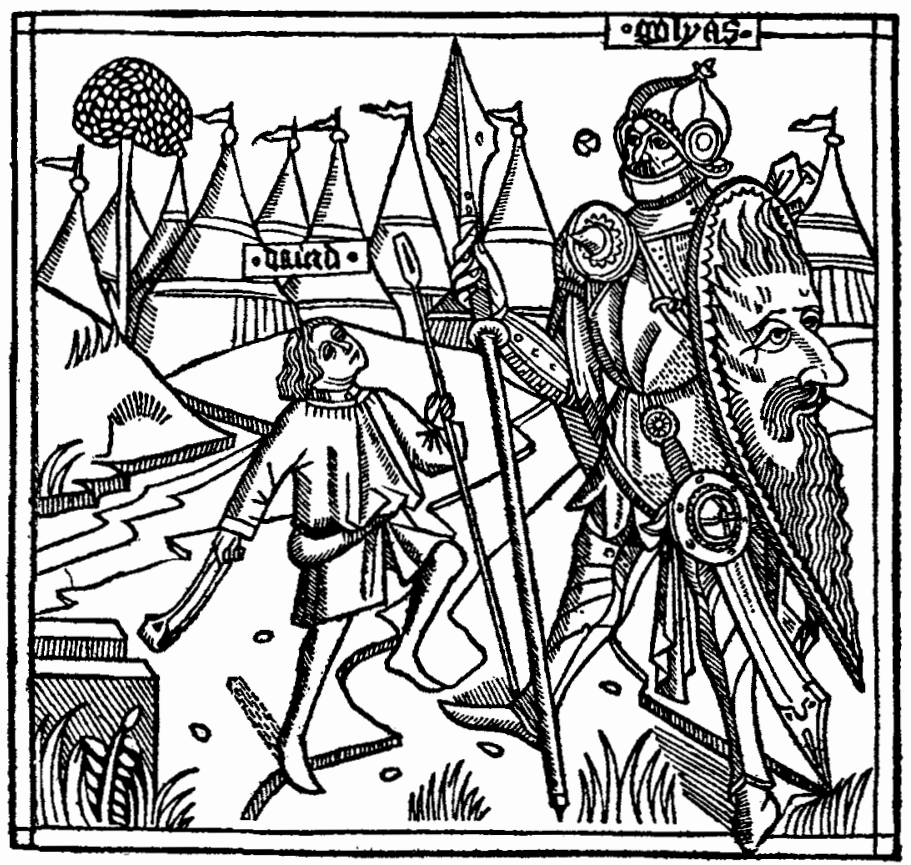

Daavidin

päivä on aina ollut joulukuun 30:s Raamatun Daavid ja hänen vastustajansa Goljat.

\begin{tabular}{|c|c|c|c|}
\hline \multicolumn{4}{|c|}{ JOULUKUU } \\
\hline 1700 & 1800 & 1900 & $\underline{2000}$ \\
\hline 1. Eligius & Eligius & Eligius & Oskari \\
\hline 2. Longinus & Beata & Beaata & Anelma, Unelma \\
\hline 3. Agricola & Zephanias & Sefanja & Vellamo, Meri \\
\hline 4. Barbara & Barbara & Barbaara & Airi, Aira \\
\hline 5. Sabina & Crispina & Selma & Selma \\
\hline 6. Nicolaus & Nicolaus & Niilo & $\begin{array}{l}\text { Niilo, Nikolai, Niko, } \\
\text { Niklas }\end{array}$ \\
\hline 7. Agatha & Agathon & Agaton & Sampsa \\
\hline 8. Saturn. & Mar. Sikiim. & Anna & Kyllikki, Kylli \\
\hline 9. Gustaf & Anna & Georg & $\begin{array}{l}\text { Anna, Anne, Anni, Anu, } \\
\text { Annikki, Anneli, Annukka, } \\
\text { Annika }\end{array}$ \\
\hline 10. Anna & Judit & Juudit & Jutta \\
\hline 11. Joachim & Daniel & Taneli & Taneli, Tatu, Daniel \\
\hline 12. Judith & Alexander & Adalbert & Tuovi \\
\hline 13. Lucia & Lucia & Lucia & Seija \\
\hline 14. Nicasius & Isidorus & Isidorus & Jouko \\
\hline 15. Christiana & Irenäus & Ireneus & Heimo \\
\hline 16. Ignatius & Lazarus & Latsarus & Auli, Aulikki, Aada \\
\hline 17. Loth & Ignatius & Ignatius & Raakel \\
\hline 18. Abraham & Abraham & Abraham & Aapo, Aappo, Rami \\
\hline 19. Isaacus & Isaac & Nikolai & likka, liro, lisakki, Isko \\
\hline 20. Ammon & Jacob & Jaakoppi & Benjamin, Kerkko \\
\hline 21. Thomas & Thomas & Tuomas Apost. & $\begin{array}{l}\text { Tuomas, Tuomo, Tommi, } \\
\text { Tomi }\end{array}$ \\
\hline 22. Joseph & Joseph & Jooseppi & Raafael \\
\hline 23. Victoria & Israel & Israel & Senni \\
\hline 24. Adam, Ewa & Adam, Ewa & Aatami, Eewa & $\begin{array}{l}\text { Aatami, Eeva, Eevi, } \\
\text { Eveliina }\end{array}$ \\
\hline 25. Jule-Dag & Joulu-päiw. & Joulupäiwä & Joulupäivä \\
\hline 26. Stephan. & Stephan. p. & Tapaninp. & Tapani, Teppo, Tahvo \\
\hline 27. Joh. Evani. & Johan. Ev. & Joh. Ewank. & Hannu, Hannes \\
\hline 28. Men. barn. d. & Wiat. Last. p. & Wiatt. lasten $p$. & Viattomien lasten p., Piia \\
\hline 29. Thom. Bisk. & Thomas Pispa & Tuomas Piispa & Rauha \\
\hline 30. David & Dawid & Taavetti & Daavid, Taavetti, Taavi \\
\hline 31. Sylvester & Sylwester & Sylwester & Sylvester, Silvo \\
\hline
\end{tabular}




\section{SUOMALAISEN ALMANAKAN KEHITYS}

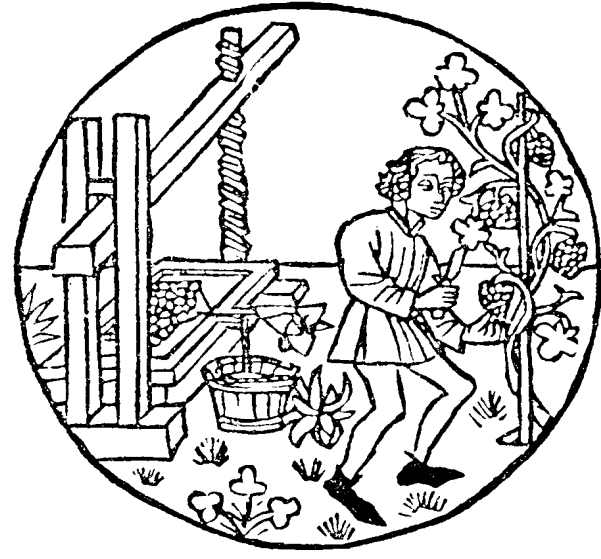

Syyskuun askareita Johannes von Gmundenin kalenterissa: Viininkorjuuta.
$S$ uomalaisen almanakan alkujuuret ovat Saksassa, jossa kirjapainotaito kehitettiin 1400-luvulla. Ensimmäinen tunnettu almanakka on vuodelta 1448 , ja se on itsensä Gutenbergin painama. Siitä on tallessa vain muutamia suikaleita, jotka löydettiin erään myöhemmin painetun kirjan kannesta. Kymmenisen vuotta myöhemmin painettuja almanakkoja on jo säilynyt ehjinä.

\section{Almanakkojen alku}

Almanakka oli aluksi yksilehtinen paperi, kuin seinätaulu, ja sen sisältökin oli hieman toisenlainen kuin nykyään. Kuukausien nimet ja kuun vaiheiden tarkat ajanhetket olivat toki almanakassa, mutta suurin osa tekstistä oli terveysopasta: siinä neuvottiin milloin oli edulliset hetket suoneniskemiseen. Suoneniskeminen (kuppaaminen eli pienemmän tai isomman verimäärän laskeminen pois ruumiista) oli tuohon aikaan muotiparannuskeino, jolla koetettiin nitistää tauti kuin tauti.

Niinpä saamme tietää, että nuorten ihmisten on hyvä lyöttää suonta yläkuulla ja vanhojen alakuulla. Uudenvuoden jälkeisenä lauantaina tämä kannatti tehdä sääriin, loppiaisena päähän, Pyhän Paavalin kääntymisenä (24.1.) hävyn tienoille jne.

1400-luvun loppupuolelta asti almanakkoja painettiin säännöllisesti ja niiden sisältö monipuolistui. Suoneniskemisen ohella ruvettiin antamaan suosiolliset ja epäsuotuisat päivät moniin muihinkin toimiin. Hyvien ja huonojen aikojen laskeminen perustui vuoden 1000 paikkeilla eläneen arabialaisen lääkärin Avicennan tutkimuksiin, ja päivät 
Keskiajalla uskottiin, että eläinradan merkit säätelevät ihmisen ruumiinosien toimintaa.

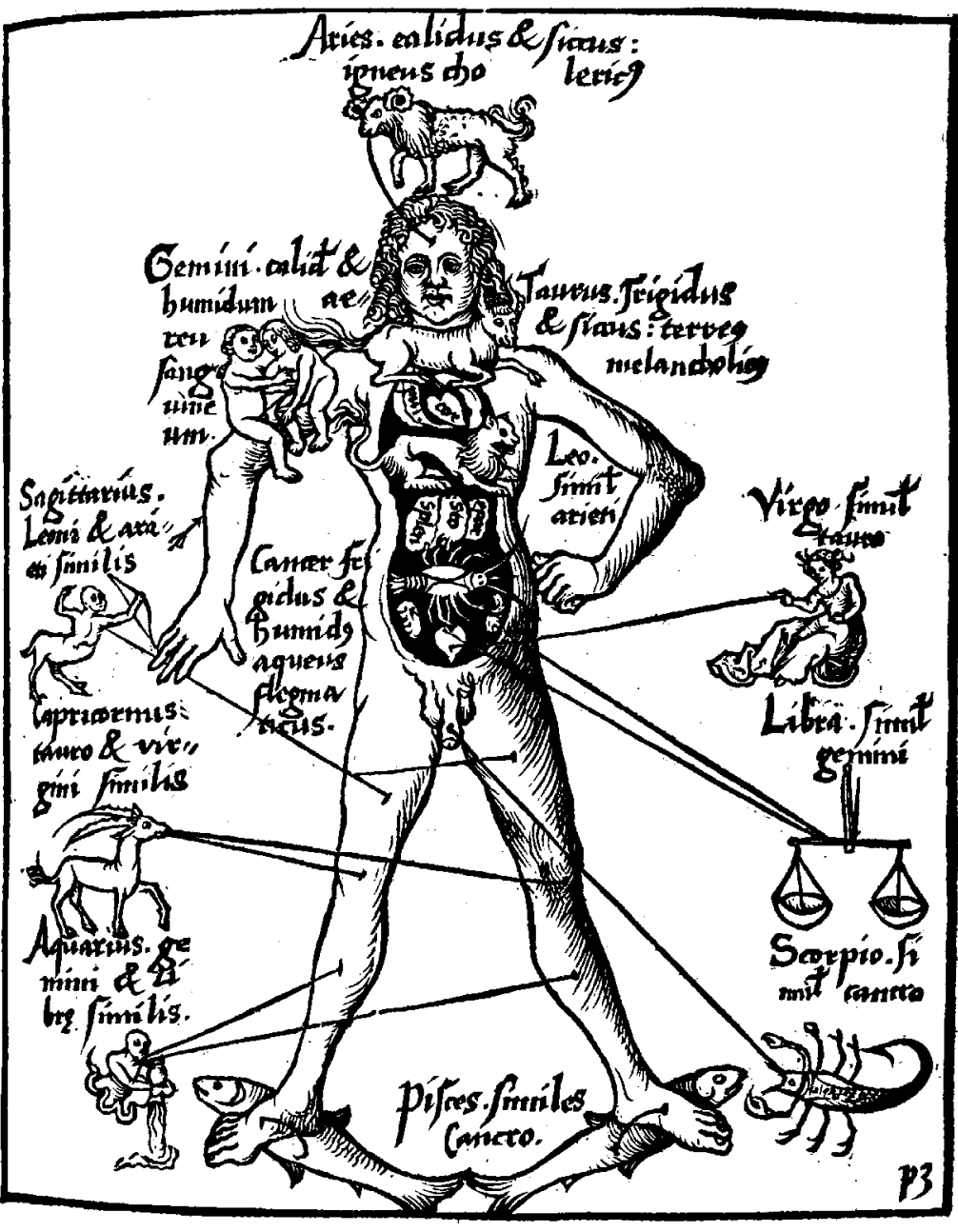

riippuivat planeettojen ja tähtien asemista.

Astrologia oli keskiajalla voimakas ja laajalti harrastettu tiede. Vaikuttihan auringon asema taivaalla vuodenaikojen vaihteluun, miksi siis aurinko ja tähdet eivät voisi vaikuttaa kaikkiin muihinkin tapahtumiin ja toimintoihin? Tuohon aikaan ajatus oli aivan mielekäs, ennen kuin oli opittu tähtien ja planeettojen todellinen luonne ja niiden kulkua sääte-

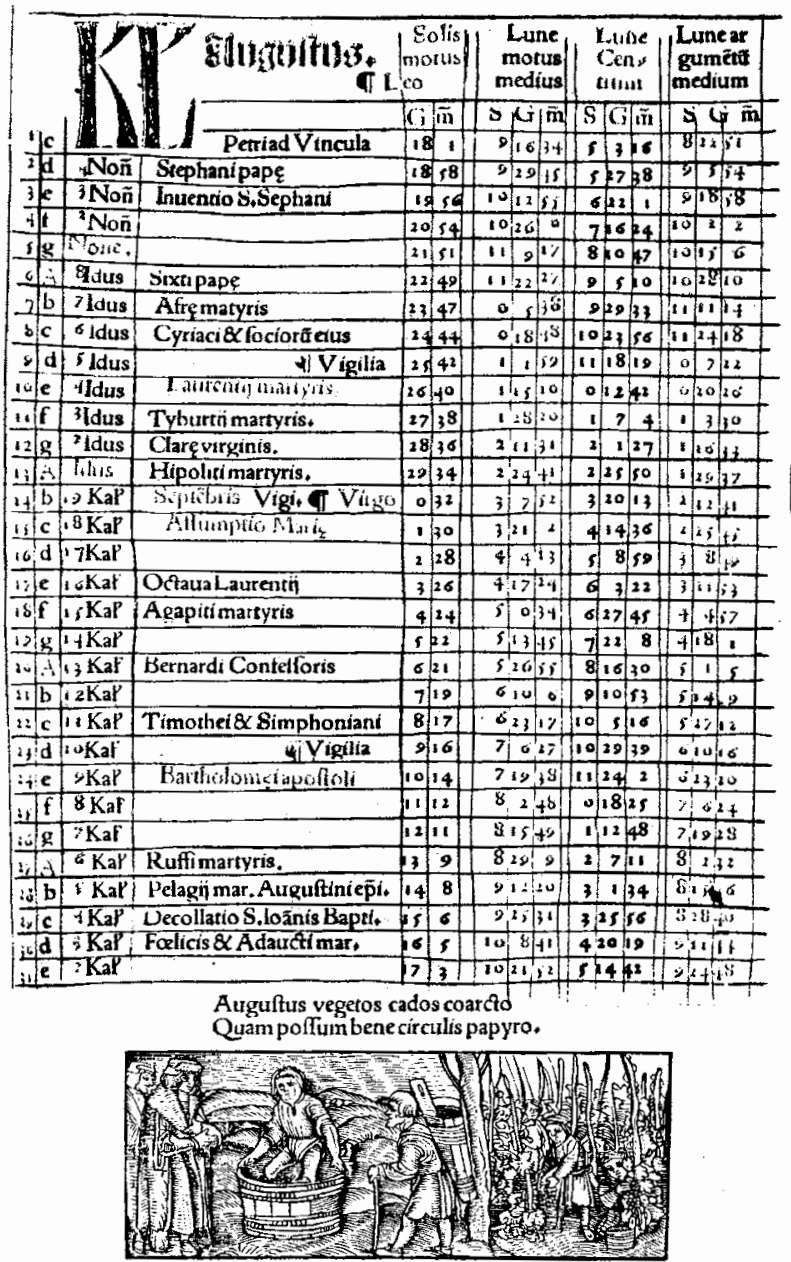

Elokuun sivu saksalaisesta almanakasta 1500-luvulta.

levät luonnonlait. Nykyäänhän astrologia on enimmäkseen viihdettä ja kaupallista toimintaa.

Niinpä planeettojen asemista ennustettiin kaikenlaisia mahdollisia tapahtumia, ja almanakkojen laajentuessa auringon ja planeettojen paikat täytyi ruveta ilmoittamaan tarkasti. Almanakoista luettiin planeettojen kohtaamiset keskenään tai kuun kanssa, samoin ne hetket jolloin planeetta oli aurinkoa vastapäätä tai "neljänneksessä" eli suoraan sivulla.

Almanakkoihin alettiin liittää usein laajojakin ennustuksia, joissa pla- 
neettain asentojen mukaan annetaan sopivat päivät niin velan maksamiseen, vaatteiden teettämiseen, parran ajamiseen, lasten vieroittamiseen, myllyyn menemiseen kuin lääkkeen ottamiseen, ostamiseen tai myymiseen, kalastamiseen ja metsästämiseen.

Almanakkojen ensimmäiset julkaisijat olivat usein lääkäreitä, sillä heiltähän saattoi varmasti saada parhaat ohjeet suoneniskemiseen.

Vuoden 1500 paikkeilla oli almanakkoihin ilmestynyt myös nimipäiviä. Alun perin pyhimyksille omistetuista muistopäivistä kehittyi nimiluettelo, joka valtasi pian suuren alan almanakasta. Hiukan myöhemmin ilmestyivät pyhä- ja juhlapäivien kohdille saarnatekstit, joissa neuvottiin mitä asioita kyseisenä pyhänä tuli kirkoissa käsitellä.

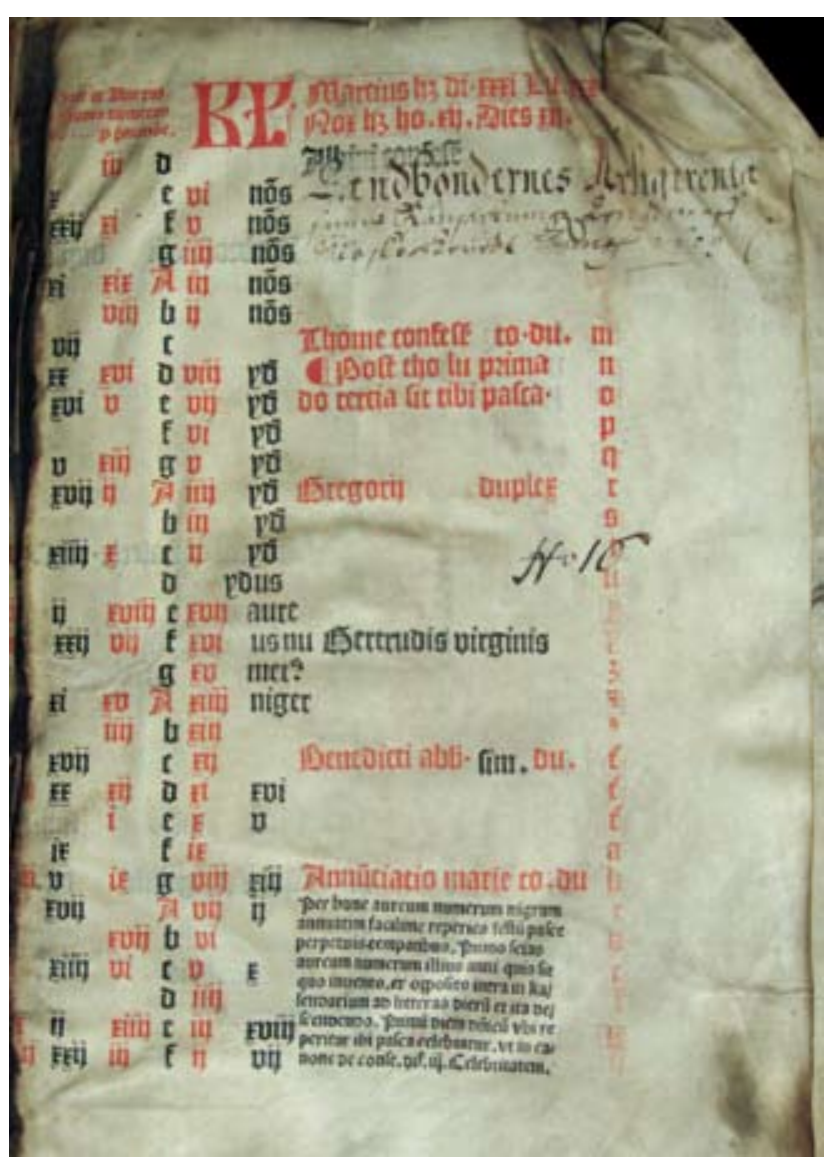

Maaliskuun sivu vuoden 1488 Turun messukirjasta. (Kuva Jyväskylän yliopiston kirjasto / Matti Salmi)
Viimeisenä keskiajan uutuutena almanakka sai sääennustukset. Ne perustuivat samoihin kuun ja planeettojen asemiin kuin muutkin ennusteet, sillä pystyivät taivaan muuttuvat merkit toki säätäkin säätelemään.

Almanakan sisällön laajentuessa jouduttiin aineisto ahtamaan yhä tiheämpään, ja siksi monissa kohdin ruvettiin käyttämään lyhenteitä. Esimerkiksi taivaan tapahtumat ilmaistiin pian pelkillä symboleilla, samoilla "myrskynmerkeillä", jotka vieläkin koristavat almanakkamme sivuja.

Yksilehtinen arkki ei enää riittänyt kaiken tietomäärän esittelemiseen, ja siksi 1500-luvun alkupuoliskolla arkki taiteltiin käteväksi neliömäiseksi kirjaseksi. Siihen voitiin lisätä sivuja enemmänkin, ja sitä saattoi kantaa taskussa aina mukana.

Almanakat saavuttivat ennustustensa ja muiden tietojensa takia hyvän suosion. Kirjapainotaidon levitessä myös almanakan teko levisi Saksan ulkopuolelle. Tanskassa ruvettiin almanakkoja julkaisemaan vuoden 1570 paikkeilla ja Ruotsissa 1580-luvulla.

Ensimmäiset pohjoismaiset almanakat olivat nimiä myöten pohjoissaksalaisten kopioita, mutta vähitellen niihin alkoi tulla myös kansallista väriä. Ensimmäinen suomalainen almanakka ilmestyi vuonna 1608.

\section{Forsiuksen almanakat}

Ennen ensimmäistä varsinaista almanakkaa olivat suomalaiset saaneet luettavakseen muutaman kalenterin. Turkua varten 1488 painettu messukirja Missale Aboense sisälsi suomalaisiin oloihin sovelletun pyhimyskalenterin. Ja Agricolan rukouskirjassa vuodelta 1544 oli kalendaario, jossa mainittiin myös auringon nousu- ja laskuajat ja päivän pituudet.

Rukouskirjojen kalendaarioita ei kuitenkaan ollut laskettu millekään nimenomaiselle vuodelle. Siksi kunnia ensimmäisen almanakkamme julkaisemisesta kuuluu helsinkiläissyntyiselle tähtitieteilijälle Sigfridus Aronus Forsiukselle (n. 1550-1624). Vuosina 1608-1623 Forsius laati ja painatti 12 almanakkaa. Koska Forsiuksen almanakat oli tarkoitettu koko valtakuntaa, eikä vain Suomea varten, ne olivat tietysti ruotsinkielisiä ja painettiinkin Tukholmassa.

Forsius sai kuninkaalta jopa erioikeuden almanakkojen valmistamiseen koko Ruotsin valtakunnassa (erioikeudesta puhutaan lisää jäljempänä tässä luvussa). Forsius oli vuonna 1612 päässyt kuninkaan suosioon, ja hän sai samalla kuninkaallisen tähtitieteilijän arvon. 


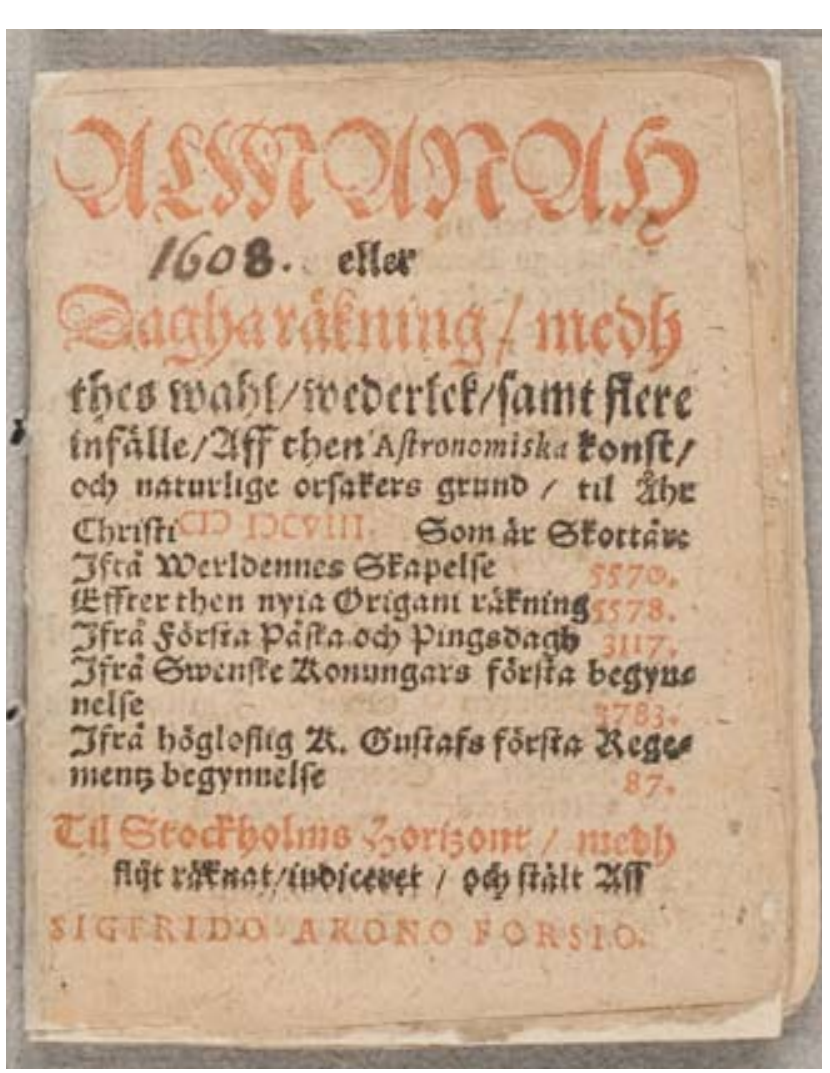

Vuoden 1608 Forsiuksen almanakan kansi.
Forsius oli paitsi tähtitieteilijä myös astrologi eli tähdistäennustaja, ja siksi hänen almanakkojensa liitteenä oli laaja "Prognosticon" eli "ennustuksia ja arvauksia kaikenlaisista tulevista tapahtumista ilmassa ja maan pälllä". Forsiuksen ennustukset koskivat myös kuninkaan ja koko valtakunnan kohtaloa. Ennustukset olivat yleensä hyvin synkkiä, ja laskelmiensa perusteella Forsius arveli esimerkiksi maailmanlopun koittavan pian.

Epäsuotuisien ennustustensa vuoksi Forsius menetti kuninkaallisen tähtitieteilijän toimen 1610-luvun lopussa, mutta almanakkaerioikeutensa hän sai pitää. Viimeinen Forsiuksen almanakka ilmestyi vuodelle 1623; Forsius kuoli seuraavana vuonna. Vuoden 1623 almanakka oli ensimmäinen, joka oli laskettu Turun horisontin mukaan; kaikki aikaisemmat oli laskettu valtakunnan pääkaupungin Tukholman mukaan.
Erilaisia suotuisuusmerkkejä Forsiuksen almanakoissa. (Piirrokset Arno Forsius)

\begin{tabular}{|l|} 
hyvä iskeä suonta \\
hyvä kylpeä (saunoa) ja kupata
\end{tabular}

\section{Turun Akatemia almanakantekijänä}

Forsiuksen kuoltua ei Suomesta löytynyt kiinnostusta almanakkojen julkaisemiseen. Turun Akatemia perustettiin 1640, ja Pietari Brahe koetti saada Akatemiaa innostumaan almanakoista. Kesti kuitenkin vuoteen 1650 asti, ennen kuin ensimmäinen Forsiuksen jälkeinen almanakka ilmestyi maassamme. Tämän jälkeen almanakkoja pystyttiin tekemään lähes kaikille vuosille.

Almanakan toimittajat olivat yleensä Turun Akatemian matematiikan professoreita, ja toimittajina esiintyy sellaisia nimiä kuin Andreas Thuronius, Jacobus Flachsenius, Andreas Simon Kexlerus ja Laurentius Tammelin.

Laurentius Tammelin julkaisi almanakkoja vuodesta 1700 alkaen parinkymmenen vuoden ajan. Hän oli myös ensimmäisen suomenkielisen almanakan laatija. Almanakka ilmestyi 1705 ja oli nimeltään "Almanach eli Ajan-Lucu. Wuonna Herran Jesuxen Christuxen Armollisen Syndymän jälkeen 1705. Turun Horizondin eli Taiwan näön jälkeen / Kirjoitettu ja asetettu Laur: Tammelinilda / Math. Prof. Turusa / Prändätty Jo. Wallilda". (Almanakan tarkkaa nimeä ei kuitenkaan tunneta, koska molemmista tallella olevista kappaleista puuttuu $\mathrm{mm}$. ensimmäinen lehti.)

Millaisia tuon ajan almanakat olivat? Voimme vähän selailla ensimmäistä kokonaisena sälynyttä suomenkielistä almanakkaa vuodelta 1706. Kuukausiaukeamilla on paljolti samoja tietoja kuin meikäläisissä 
almanakoissa oli vielä 1970-luvun alussa. Mutta on myös sellaisia tietoja, joita nykyään ei enää julkaista: 1700-luvun almanakoista löytyy eläinradan merkki, jossa kuu sijaitsee, ja joidenkin päivien kohdalla on sääennustus.

Varsinaisen kalenterin jälkeen on opettavainen artikkeli, joka vuonna 1706 oli "Auringon ja Kuun Pimenemisen Aluista ja syistä ja mistä ne tulewat". Artikkelin jälkeen on ennustusosa, Prognosticon, ja sitten vuoden 1706 auringon- ja kuunpimennykset. 40-sivuisen almanakan päättää luettelo "Wuotuiset Markinat Suures Ruhtinan Maasa Suomesa ja Pohian Maalla".

Niin markkinapäiväluettelot kuin valistavat artikkelitkin ovat säilyttäneet paikkansa almanakassa nykypäiviin asti. Artikkelien aihepiiri on vaihdellut opettavaisista tarinoista arkisiin käytännön ohjeisiin.

Joitakin vuoden 1706 almanakan piirteitä on vuosikymmenien aikana karissut pois. Ennustusosa, Prognosticon, jätettiin lopullisesti pois 1726,

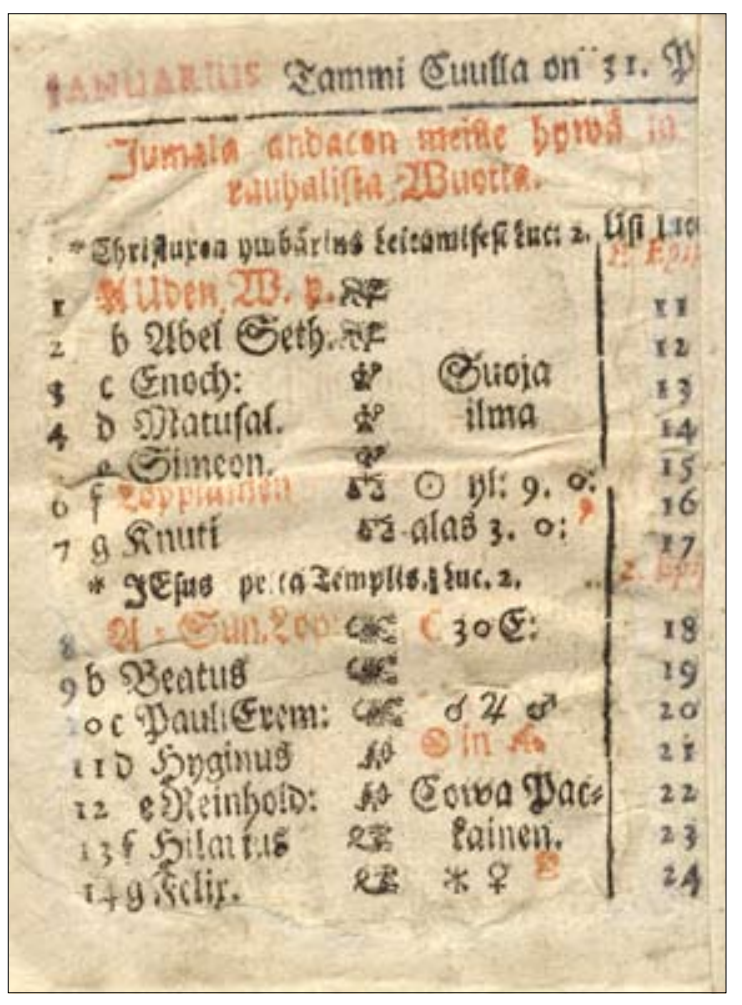

Vuoden 1705 almanak-

ka oli ensimmäinen, joka julkaistiin suomen kielellä. vaikka se kuului ilmeisesti almanakan suosituimpiin osastoihin. Kuun liike eläinradalla ja sääennustukset olivat paljon pitkäikäisempiä, sillä ne säilyivät almanakoissa pitkälle 1800-luvulle asti.

Vuonna 1713 alkoi isoviha, ja almanakkojen julkaisemiseen tuli kolmen vuoden tauko. Laurentius Tammelin jatkoi almanakkojen sarjaa pakolaisena Tukholmassa, mutta vuosina 1717-1725 almanakat olivat pelkästään ruotsinkielisiä.

Suomenkielinen almanakkasarja sai jatkoa taas vuodesta 1726 alkaen, jolloin allakantekijäksi ryhtyi Nicolaus Hasselbom, Tammelinin seuraaja Turun Akatemian matematiikan professorina. Vuosina 1729-30 almanakat toimitti poikkeuksellisesti ruotsalainen fyysikko Andreas Celsius, jonka nimi on suomalaisillekin tuttu nykyisen lämpötila-asteikon keksijänä.

Vuonna 1749 suomalainen almanakantekoperinne katkesi yli puoleksi vuosisadaksi, kun kuningas myönsi erioikeuden almanakkojen tekoon vastaperustetulle Ruotsin Tiedeakatemialle. Venäjän vallan alkuun asti, vuoteen 1809, kaikki suomenkielisetkin almanakat tehtiin Ruotsissa.

Allakanteon siirtyminen Ruotsin puolelle merkitsi kieliasun huononemista. Almanakkatekstit ja kalenteriosuutta seuraavat artikkelit kirjoitettiin Tukholmassa ruotsiksi, ja käännöstyön ruotsista suomeen saattoi tehdä kirjuri, joka ei juurikaan ymmärtänyt almanakan asiasisältöä. Käännöksistä valitettiin Suomen puolella, ja lopulta 1800-luvun alussa alkoi Suomen Talousseura hankkia valistavat kirjoitukset. Talousseura huolehti almanakan artikkeleista aina 1970-luvulle asti.

\section{Almanakan säätiedot}

Kun almanakka alkoi Suomessa ilmestyä 1600-luvulla, oli almanakan sivuilla runsaasti säämerkintöjä. Esimerkkinä voi tarkastella ensimmäistä suomenkielistä almanakkaa vuodelta 1705 . Siinä on suunnilleen kerran viikossa sääennustus.

Tammikuulta voimme lukea, että alkupäiviksi luvataan "Suoja ilma", 12. päivän tienoilla on "Cova Packainen", 16. päivän kohdalla "Kylmä Ilma", mutta viikkoa myöhemmin taas "Suoja ja luminen ilma".

Puhtaasti astrologisia periaatteita noudatettiin sään arvaamisessa 1700luvun puoliväliin asti. Tällöin almanakan julkaiseminen kuitenkin siirtyi erioikeudella Ruotsin Tiedeakatemialle, eivätkä oppineet miehet enää 
Vuoden 1794 almanakan heinäkuun aukeama. Välillä ennustetaan "Ukkoisen Jyrinää", välillä "Hajotettuja Pilwiä".

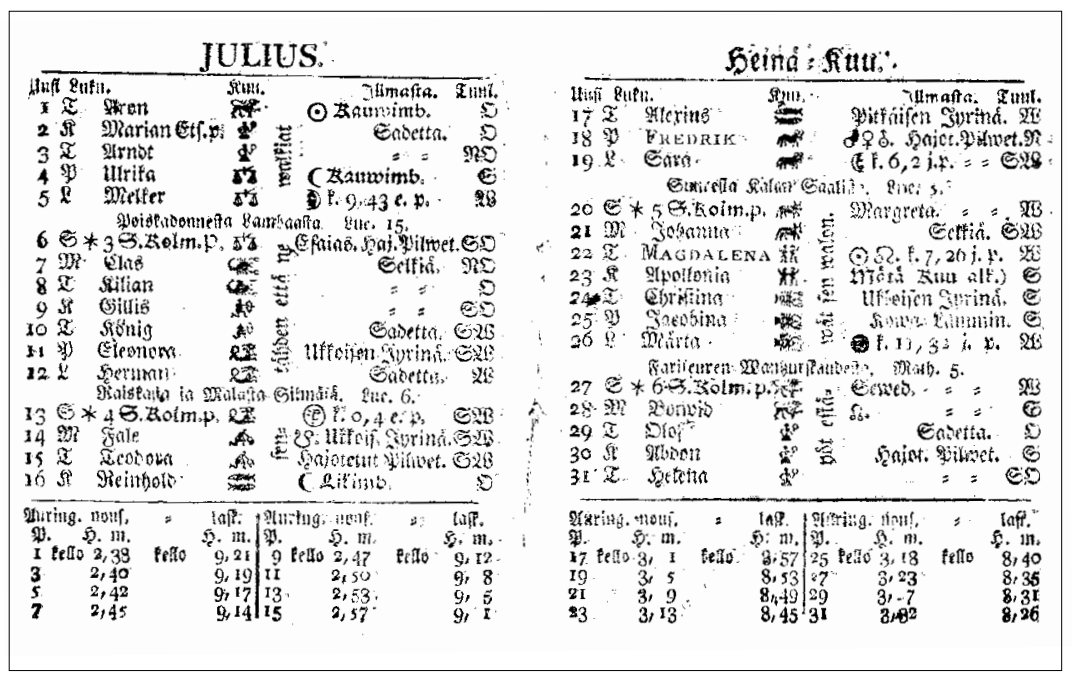

kehdanneet julkaista sääennustuksia moneen kertaan pätemättömiksi todettujen taivaan merkkien mukaan.

Säätietoja almanakassa oli kuitenkin oltava. Tämä oli opittu karvaan kokemuksen tietä. Matematiikan professori Nicolaus Hasselbom oli jättänyt ennustukset pois kahtena vuonna, 1726 ja 1727, sillä seurauksella, että almanakat "ei ole erinomattain cansalle kelwannet/sen syyn tähden/ että minä olen poisjättänyt ne totutut arwoituxet ilmasta", kuten professori joutui myöhemmin toteamaan. "Niin en ole minä tahtonut pidemmäld asetta itziän yhtä sencaldaista caickein halausta ja sencaldaista wanha tapa wastoin." Hasselbom otti arvoitukset takaisin almanakkaan muristen, että "mitä wahwutta nijssä on/on caickein aicain coettelemus jo ennen opettanut".

Tiedeakatemia keksi kaksikymmentä vuotta myöhemmin säämerkintöjen jatkamiselle ovelan tavan. Se ei enää julkaissutkaan ennustuksia, vaan havaintoja jonkin menneen vuoden säästä. Koska sään oli arveltu noudattavan kuun vaiheita ja kuu taas kiertää taivaalla yhdeksäntoista vuoden jaksoissa samanlaista rataa, valittiin havainnot 19 vuoden takaa.

Niinpä vuoden 1749 almanakassa on säämerkintöjä siitä, mitä "ilmasta on waarinotettu Upsalassa vuonna MDCCXXX". Jos joku halusi
Vihoviimeinen sääennustus oli vuoden 1886 joulukuussa, jolloin todetaan lyhyesti: "Pakkanen".

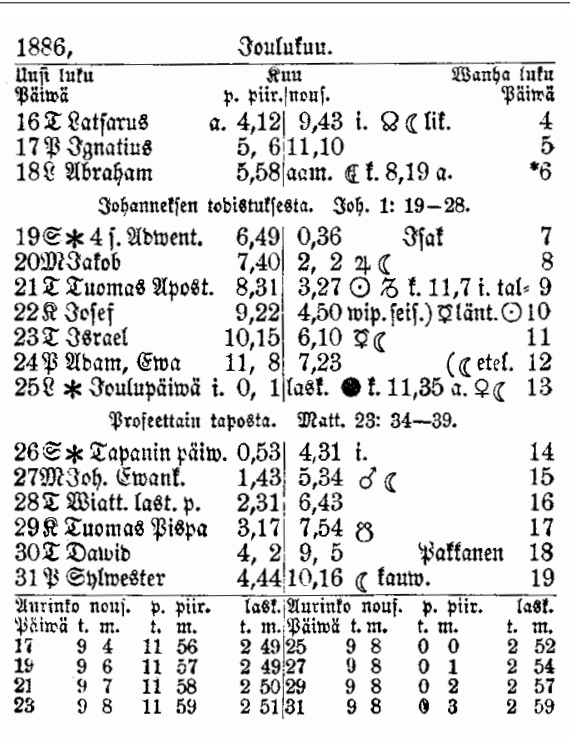

pitää almanakan säämerkintojä ennustuksina, se oli hänen oma asiansa. Tiedeakatemia julkaisi almanakassa vain todellisia havaintoja.

Seuraavana vuonna, 1750, on merkintöjä Uppsalan säästä vuodelta 1731 , seuraavana vuonna vuodelta 1732 ja niin edelleen. Vuodesta toiseen ja vuosikymmenestä toiseen almanakka uskollisesti selosti 19 vuoden takaista säätä.

Havaintopaikkakunnassa tapahtui kyllä muutoksia, mikäli sitä lainkaan almanakassa ilmoitettiin. Kun allakanteko siirtyi Ruotsista takaisin Turun Akatemialle, kerrottiin esimerkiksi vuoden 1809 allakassa Padasjoella 1790 vallinnut sää.

Almanakan horisontin muuttaminen Helsinkiin 1830-luvun alussa aiheutti huolia allakantekijöille. Helsingistä ei vanhoja säähavaintoja ollut missään koottuna. Fysiikan professori Hällström aloitti kiireen vilkkaa havainnot omassa kotipihassaan, ennen kuin havaintojen teko voitiin siirtää yliopiston vastaperustetun magneettismeteorologisen observatorion (nykyisen Ilmatieteen laitoksen) huoleksi.

Kun allakassa ei kuitenkaan haluttu käyttää muiden paikkakuntien kuin Helsingin havaintoja, annettiin tähtitieteen professorille, Friedrich Argelanderille, valtuudet keksiä merkinnät muutamana vuotena omas- 
ta päästään. Argelander onnistuikin ennustuksissaan niin hyvin, että havainnontekijät myöhemmin haikeudella muistelivat Argelanderin aikaa: "Hänen laatimansa almanakat kertoivat sän̈kin kohdalleen, mutta myöhemmät säätiedot ovat pelkkää höpötystä."

Ei Suomen kansa kovin vakavasti almanakan säätietoja ottanut. Luopioisissa sanottiin iloisesti, että "kyllä ennustukset aina paikkansa pittää kunnei ilmat vaan ruppee rillaamaan".

Perinteen voima oli kuitenkin niin vahva, että säätiedot jatkuivat pitkälle 1800-luvun lopulle. Vuosisadan puolivälissä merkintöjen tiheys alkoi kuitenkin järjestelmällisesti vähentyä. Muutamien kuukausien kohdalla oli vain jokunen maininta, ja 1870-luvulla merkinnät yhä harvenivat.

Viimeinen naula säätietojen arkkuun tuli vuonna 1886. Tällöin olisi pitänyt kertoa 19 vuoden takaisesta säästä eli vuodesta 1867 . Tuo vuosi oli kuitenkin ollut erittäin ankara nälkävuosi, eikä paatuneinkaan allakantekijä rohjennut ennustaa uutta nälkävuotta. Siksi vuoden 1886 muutama harva merkintä on paljon toiveikkaampi kuin 19 vuoden takainen sää olisi antanut aihetta. Tällä kertaa ennustukset osuivatkin aika hyvin kohdalleen, sillä 1886 oli tavallista lämpimämpi vuosi.

Seuraavan vuoden almanakassa ei ole enää ainuttakaan säämerkintää, eikä myöskään sen jälkeen.

\section{Vuoden tunnusluvut}

Entisajan kalentereissa oli alkuaukeamalla komea rimpsu vuoden tunnuslukuja. Esimerkiksi vuoden 1706 suomalaisessa kalenterissa on seuraavat merkinnät:

\section{Cullainen lucu 16}

Auringon vijri 7

Ruomalaisten veronlucu 14

Sunnuntai-Bookstawi $G$

Mitä nämä luvut tarkoittivat? Niissä oli lyhyessä muodossa lueteltu sellaiset tekijät, jotka yksikäsitteisesti kertovat kyseisen vuoden päivät, pyhät ja kuun liikkeet.

Kultainen luku (eli kuun jakso) tarkoittaa vuoden järjestyslukua 19- vuotisessa jaksossa. Kuun vaiheet toistuvat suunnilleen samoilla päivillä aina 19 vuoden välein, ja täydenkuun hetket koko 19-vuotisessa jaksossa oli merkittynä kultakirjaimin vanhan Ateenan julkisiin monumentteihin. Siitä nimi kultainen luku.

Auringon jakso (tai auringon piiri) tarkoittaa vuoden järjestyslukua 28 -vuotisessa jaksossa. Viikonpäivät sattuvat 28 vuoden välein aina samoille kuukauden päiville.

Roomalainen veroluku merkittiin kalentereihin vanhan perinteen mukaisesti, vaikka sillä ei enää aikoihin ollut ollut mitään käytännön merkitystä. Tämä tunnusluku oli otettu käyttöön Roomassa vuoden 300 paikkeilla. Veroluku tarkoittaa vuoden sijaintia 15-vuotisessa jaksossa, jonka mukaan roomalaiset veronkantajat tekivät kierroksiaaan.

Sunnuntaikirjain kertoo, millä viikonpäivällä vuosi alkaa. Entisaikojen kalentereissa vuoden päivät merkittiin kirjaimilla $A-G$ siten että 1.1. oli A, 2.1. B jne. Esimerkiksi vuosi 2013 alkoi tiistailla, joten sunnuntaille sattuva kirjain on $\mathrm{F}$.

Vuoden tunnusluvut hävisivät vähitellen kalentereistamme, kun samat asiat ruvettiin kertomaan almanakoissa toisella tavalla. Sunnuntaikirjain tuli tarpeettomaksi, kun vuodesta 1787 alkaen almanakkamme rupe-

Vuoden tunnusluvut löytyvät vanhimmistakin almanakoistamme. Kuva vuoden 1608 almanakasta.

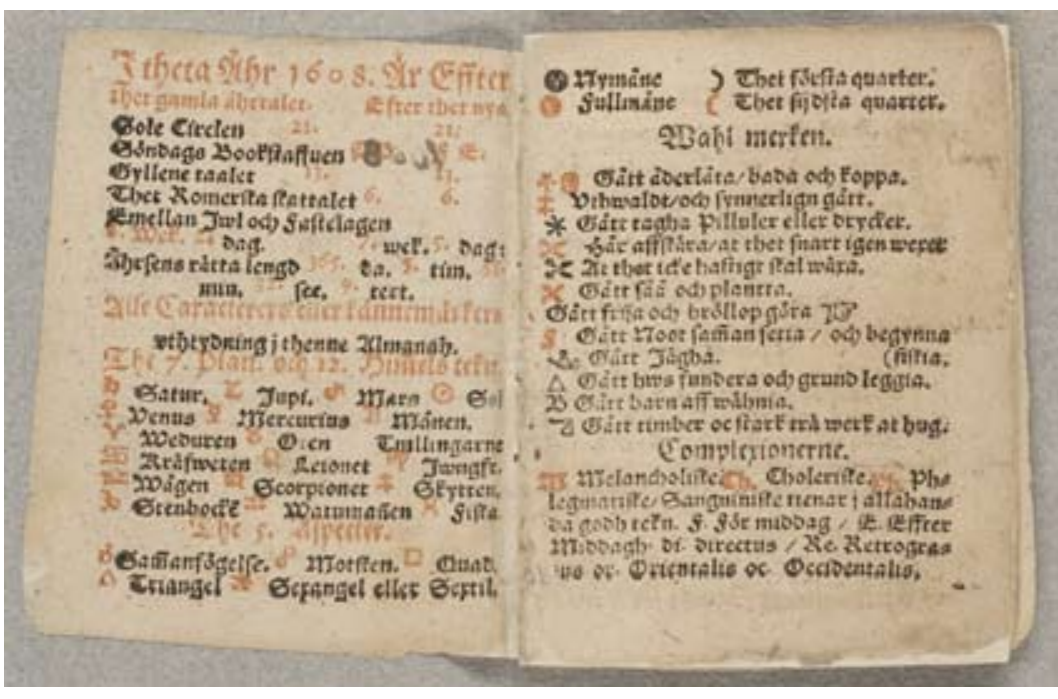


sivat käyttämään päiville viikonpäivien alkukirjaimia eikä enää $\mathrm{ABC}$ tunnuksia. Kultaista lukua ei tarvittu, kun kuun vaiheet merkittiin kuukausisivuille.

Esimerkiksi Ruotsin kansanalmanakasta ("Den vanliga almanackan") tunnusluvut löytyvät edelleen, vaikka meikäläinen Yliopiston almanakka on pudottanut ne pois. Otavan Suomen kansan kalenteri jatkaa vanhaa perinnettä ja julkaisee tunnusluvut alkusivuillaan.

\section{Kalenterit kehittyvät 1800-Iuvulla}

Suomi joutui Venäjän vallan alle 1809, ja muutos heijastui heti myös almanakoissa. Ruotsin Tiedeakatemia yritti jatkaa suomalaisten almanakkojen julkaisemista, mutta Venäjän keisari ei halunnut maahan läntisen naapurimme propagandaa. Suomen almanakat ruvettiin taas tekemään Suomessa.

Turun Akatemia palasi vanhaan osaansa almanakan julkaisijana. Akatemian nimi ja sijaintipaikka muuttui 1800-luvun alkupuolella. Turun palo 1827 sai aikaan sen, että keisari siirsi Akatemian Suomen uuteen
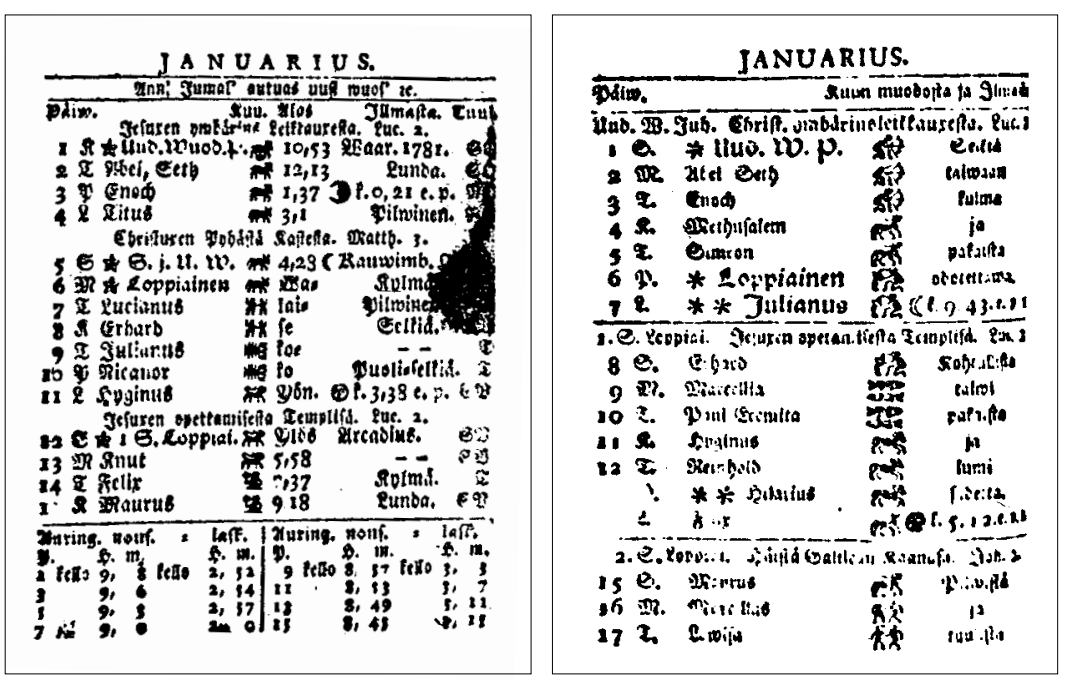

Jo vuodelle 1800 julkaistiin suomalainen almanakka myös Viipurissa, mutta siinä käytetty kalenteri oli Venäjän juliaaninen eikä Suomen "parannettu kalenteri". Vasemmalla Turun almanakan tammikuuta, oikealla Viipurin almanakan. pääkaupunkiin Helsinkiin. Akatemia sai samalla nimen Keisarillinen Aleksanterin Yliopisto. Suomen itsenäistyttyä 1918 nimi muutettiin Helsingin yliopistoksi.

Keisarin myöntämä almanakkaerioikeus jatkui yliopistolla koko 1800luvun ja vielä lähes koko 1900-luvun vuoteen 1995 asti. (Erioikeudesta kerrotaan jäljempänä tässä luvussa.)

Vuoteen 1810 asti ainoa varsinainen almanakka oli ollut pieni, neliömäinen "kansanallakka". Ruotsin vallan aikana oli 1738 ruvettu julkaisemaan ruotsalaista Valtiokalenteria, jossa esiteltiin valtion tärkeimmät laitokset ja virkamiehet. Kun Suomi liitettiin Venäjän valtakuntaan, myös Valtiokalenterin julkaiseminen annettiin tehtäväksi Turun Akatemialle.

Turun Akatemian, sittemmin Keisarillisen Yliopiston toimittama Valtiokalenteri ilmestyi ensimmäisen kerran vuodelle 1811 ruotsinkielisenä ja vuodesta 1869 alkaen myös suomenkielisenä. Valtiokalenterissa on myös tähtitieteellisiä tietoja sisältävä kalendaario-osa. Valtiokalenterin sisältö on myöhemmin laajentunut ja siitä on paisunut yli 1000-sivuinen kirja, joka edelleen ilmestyy tärkeänä vuosittaisena tietoteoksena. Julkaisijana on edelleen Helsingin yliopisto.

Kansanalmanakassa ei tapahtunut 1800-luvulla suuria muutoksia.
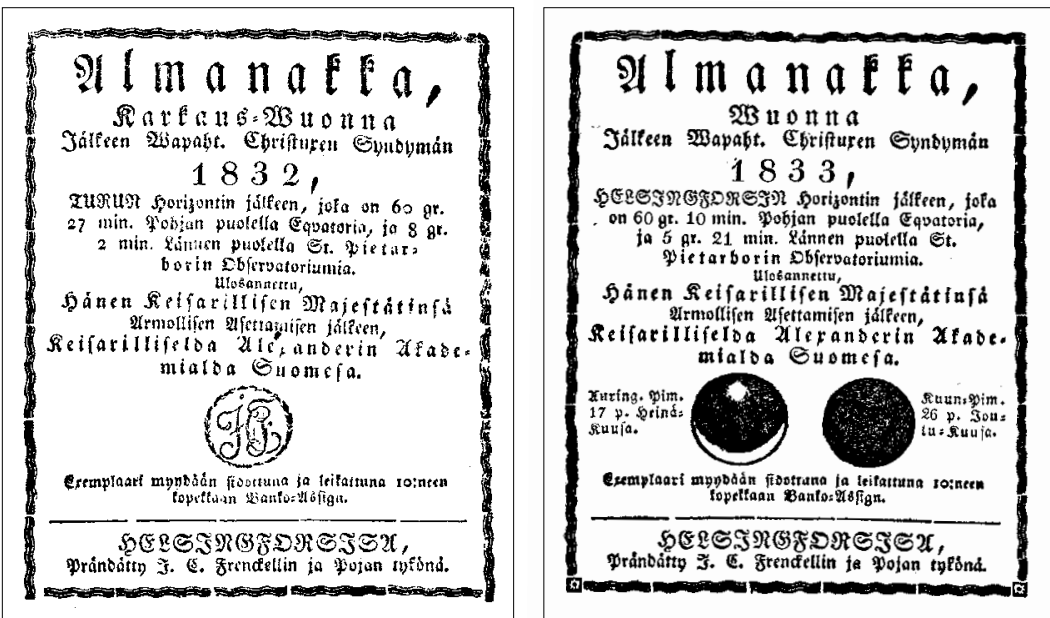

Vuoden 1832 almanakka julkaistiin vielä Turun horisontin mukaan, vuodesta 1833 alkaen Helsingin horisontin. 

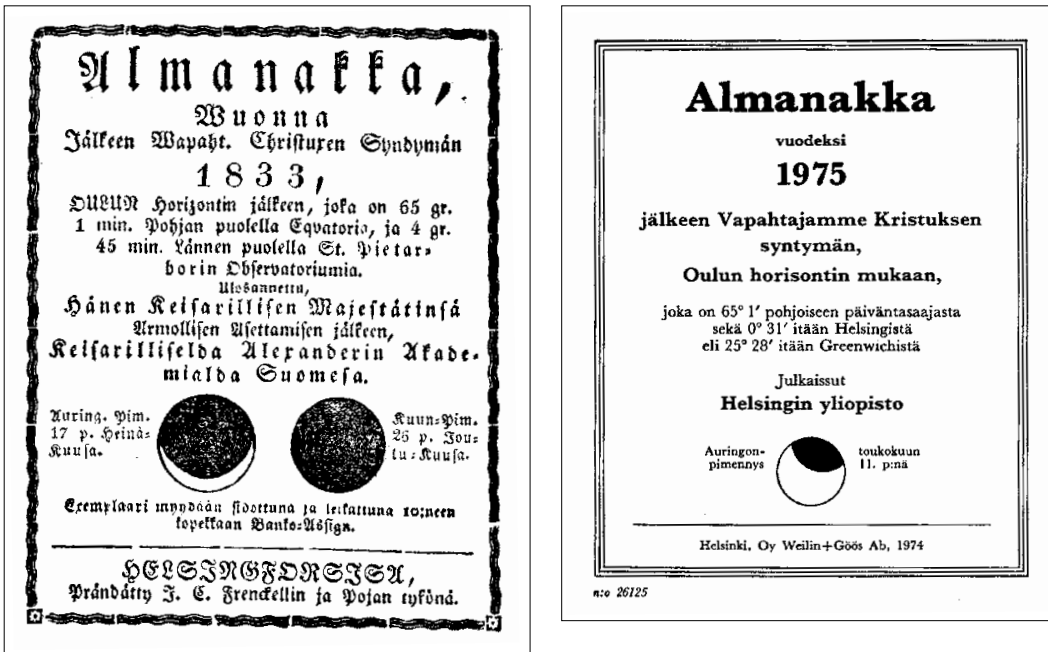

Vuoteen 1832 asti almanakan tiedot laskettiin Turun horisontin mukaan, vuodesta 1833 alkaen uuden pääkaupungin Helsingin mukaan. Samana vuonna 1833 Helsingin almanakka sai rinnalleen toisen almanakan, jonka tiedot oli laskettu Oulun horisontin mukaan.

Syynä Oulun rinnakkaisversion tekoon saattoi olla ruotsalaisten kilpailu. Kun Ruotsin Tiedeakatemia ei enää voinut julkaista Turun almanakkaa, alkoivat ruotsalaiset painaa suomenkielistä almanakkaa, jonka tiedot oli laskettu Haaparannan horisontin mukaan. Haaparannan almanakka ilmestyi vuodelle 1812 ja sitten säännöllisesti vuodesta 1830 alkaen.

Haaparannan almanakan maahantuonti Suomeen myytäväksi oli kielletty, mutta pohjoissuomalaiset saattoivat käydä ostamassa almanakkansa rajan takaa. Mutta kun Pohjois-Suomi sai oman Oulun almanakkansa, ei ollut enää tarvis käydä Ruotsin puolella kalenteriostoksilla.

1800-luvun puolivälistä lähtien alkoi suomalaisten almanakkojen valikoima hiljakseen lisääntyä. Ensimmäiset uutuudet olivat kansanalmanakan tapaisia, mutta vuosisadan lopulla rupesi markkinoille tulemaan taskualmanakkoja. Oheiseen listaan on koottu luetteloa 1800-luvulla julkaistuista almanakoista.

\section{Uusia kalentereita 1800-luvulla}

usia almanakkoja ja kalentereita, joita ruvettiin 1800-luvulla julkaisemaan perinteisen kansanalmanakan lisäksi.

$\begin{array}{lll}\text { Ensimmäinen } & \text { Kalenterin } & \text { Kalenterin } \\ \text { julkaisuvuosi } & \underline{\text { nimi }} & \text { julkaisija }\end{array}$

1811 Finlands stats-calender Turun Akatemia

1850 Miniatur almanach Öhmanska Bokhandeln

1865 Almanach med 4 porträtter Wasenius\&C

1869 Suomenmaan Keisarillinen Aleksanterin yliopisto

Waltiokalenteri

1872 Pietarin suomalainen Pietarin Sanomat kalenteri

1879 Suomalainen kansankalenteri Wenäjällä

1881 Kansanvalistusseuran kalenteri

1883 Fickkalender

1886 Kalender för finska

arméns befäl

1888 Annotations-almanack

1888 Muistialmanakka

1888 Blåbandet

1888 Sininauha

1888 Damkalender

1888 Finlands almanack

1888 Suomen almanakka

1888 Taskukalenteri

1893 Nais-kalenteri

(Pietarilaiset kirjakaupat)

Kansanvalistusseura

Frenckell\&Son

Weilin\&Göös

Weilin\&Göös

Nykterhetens Vänner

Raittiuden ystävät

Weilin\&Göös

Weilin\&Göös

Weilin\&Göös

Weilin\&Göös

Weilin\&Göös

1893 Pyhän Sergein ja Hermanin

Weljeyskunnan kalenteri

1894 Universalalmanack

1894 Yleisalmanakka

Weilin\&Göös

Weilin\&Göös

\section{Kalenteritulva 1900-Iuvulla}

Kalentereiden määrät ja tyypit ovat 1900-luvulla huimasti lisääntyneet. Aluksi syntyi erilaisia tasku- ja muistikalentereita, ja sitten väripainatuk- 
sen levitessä 1960-luvulla alkoi kuvakalentereiden nousuaika.

Vuosisadan alkupuoliskon kalentereista löytyy tarkka luettelo Suomen almanakan juhlakirjassa, jonka Weilin\&Göös ja Helsingin yliopisto julkaisivat 1950-luvulla. Tuolloin tuli ensimmäisen Forsiuksen almanakan julkaisemisesta kuluneeksi 350 vuotta. Helsingin yliopiston kirjasto kävi tuolloin läpi kaikki vapaakappaletoimistossa olevat kalenterit.

Vapaakappalelain mukaan kaikista painotuotteista, myös kalentereista, toimitetaan kirjapainoista vapaakappaleet yliopiston kirjastoon. Vapaakappaleet ovat siellä tutkijoiden ja muiden tarvitsijoiden käytössä.

Vuonna 1957 löytyi vapaakappaletoimistosta noin 235 erinimistä kalenteria. Sieltä löytyy Äidin kalenteria ja Isän kalenteria, Emännän kalenteria ja Jätkän kalenteria.

Oma kalenteri tai almanakka on $\mathrm{mm}$. apteekeilla, aseveljillä, hevosmiehillä, inkeriläisillä, kemisteillä, kirkkokansalla, käsityöläisillä, poliiseilla, toimihenkilöillä, työväellä, Helsingin Sanomien asiamiehillä ja Maan Romun ystävillä.

Seuraavan kerran vapaakappaletoimiston kalenterikokoelmat ruodittiin läpi neljäkymmentä vuotta myöhemmin, kun erioikeuden loppumisen jälkeen perustettiin Yliopiston almanakkatoimisto. Almanakkatoimisto keräsi tiedot erilaisista kalentereista lähinnä 1980- ja 1990luvulta. Nyt löytyi kaikkiaan noin 1480 taskukalenteria ja noin 1260 seinäkalenteria.

Niistä osa oli sellaisia, joita oli julkaistu jo 1900-luvun alkupuoliskolla, mutta valtaosa oli tietysti aivan uusia.

Erilaisten kalenterien määrä kasvoi entisestään 1990-luvun loppupuolella, kun Helsingin yliopiston vuosisatainen almanakkaerioikeus oli lopulta purettu.

\section{Almanakkaerioikeus}

Almanakkaerioikeuden juuret ulottuvat Ruotsin vallan ajalle 1600- ja 1700-luvulle. Kuninkaan kassa oli jatkuvien sotien vuoksi aina tyhjä, eikä kruunu pystynyt maksamaan palkkaa kaikille virkamiehilleen. Palkan sijaan saattoi pappi tai professori saada tulolähteekseen jonkin maatilan, josta hän sai elantonsa luonnontuotteina tai tilan tuotosta saatuna rahana.

Kun kuningas Kustaa Aadolf nimitti Sigfridus Aronus Forsiuksen kuninkaalliseksi tähtitieteilijäksi, maksettiin palkka almanakkaerioikeudella. Kukaan muu ei Ruotsin valtakunnassa saanut julkaista almanakkoja, ja Forsius sai almanakoista tulevat tulot itselleen. Painotuotteiden menekki ei 1600-luvun alussa ollut kovin suuri, ja Forsius valittelikin almanakkojen heikkoa tuottoa.

Forsiuksen almanakkaprivilegio oli henkilökohtainen, ja hänen kuoltuaan almanakkojen teko oli taas vapaata 1700 -luvun puoliväliin asti. Tuolloin oli vastikään perustettu Ruotsin Tiedeakatemia, jolle ei kuitenkaan pystytty antamaan kylliksi käyttövaroja. Avuksi tuli jälleen almanakkaerioikeus. Kukaan muu kuin Tiedeakatemia ei saanut julkaista almanakkoja.

Toisena syynä Tiedeakatemian saamaan privilegioon oli myös almanakkojen vaatima tarkkuus. Markkinoille ei haluttu sellaisia kalentereita, joiden tietoihin ei voinut luottaa, ja siksi almanakkojen tekijäksi valittiin luotettavin taho, Tiedeakatemia.

Kun Suomi joutui Venäjän vallan alle, antoi Suomen kenraalikuvernööri vastaavan erioikeuden Turun Akatemialle kahdeksi vuodeksi,

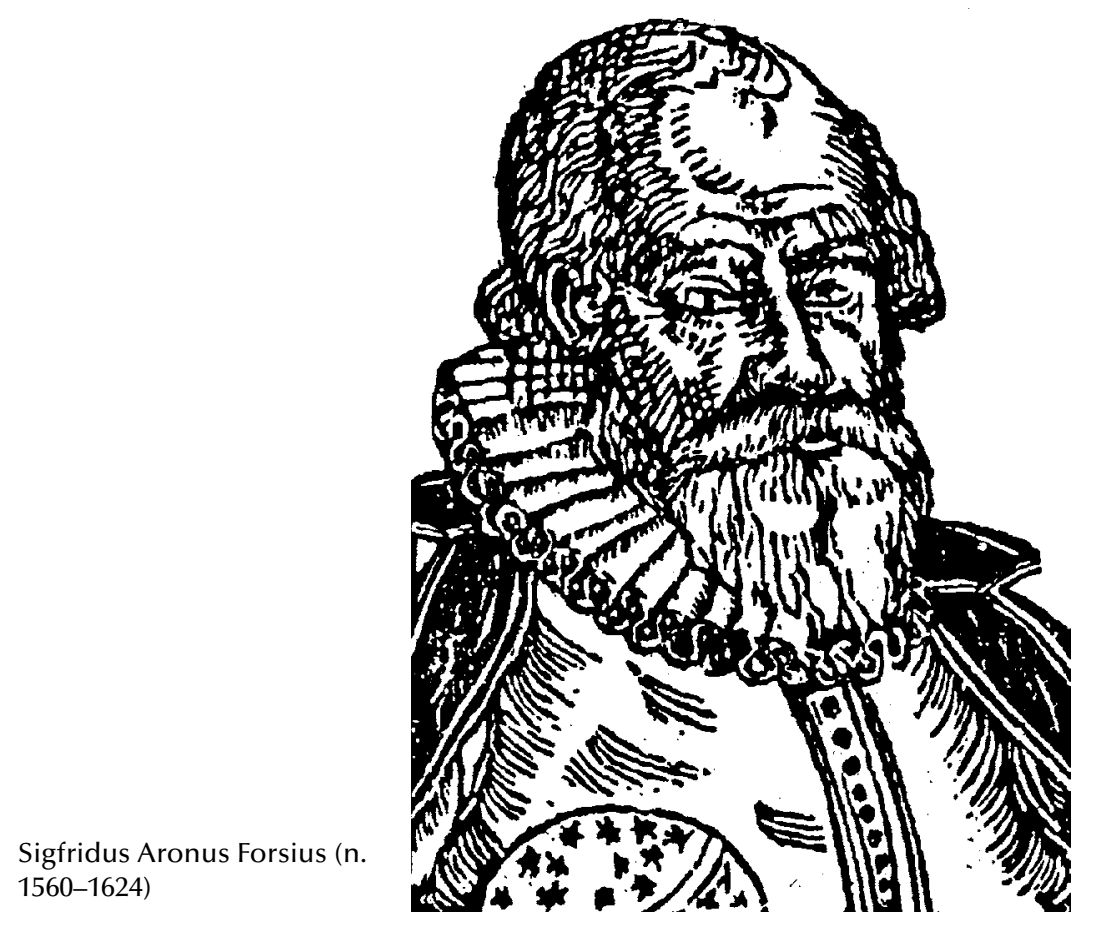




\section{Forsiuksen almanakkaerioikeus}

Ensimmäinen almanakkaerioikeus myönnettiin meillä jo 1600-luvun - alussa. Kustaa II Aadolfin kirje elokuulta 1613:

"Erioikeudet Maisteri Sigfridille painattaa Almanakkoja. Tukholmasta 5. Elokuuta Vuonna j.n.e. 1613. Me Kustaa Adolf j.n.e. Teemme tiettäväksi, että me olemme sallineet, niinkuin me myös tämän meidän avoimen kirjeemme voimalla sallimme kunnialliselle ja oppineelle Miehelle, Maisteri Sigfrid Aronukselle, ettei kukaan kotimaassa tai ulkomailla saa ilman hänen lupaansa ja suostumustaan painattaa almanakkoja, jotka hän itse arvioi ja laskee, tai sellaisia, jotka ilman hänen lupaansa ja suostumustaan on painettu, tänne valtakuntaan tuoda ja [täällä] myydä. Jos joku joutuu siitä kiinni, niin lankeavat kaikki Kappaleet edellä mainitulle Maisteri Sigfridille. Ja se, joka on antanut ne painaa tai on niitä kaupannut, langetettakoon siitä tämän meidän kieltomme tähden 40 Taalarin sakkoihin meille ja Kruunulle. Sen tähden käskemme meidän Käskynhaltijoitamme ja kaikkia muita joiden meidän tähtemme tulee tehdä ja katsoa, että he tätä valvovat ja seuraavat, [niin] että edellä mainitulle Maisteri Sigfridille tapahtuu, mikä oikein on. Siten se tapahtuu meidän armollisen mielisuosiomme mukaan ja jokainen tietäköön sen mukaan toimia. Annettu kuten yllä [on päivätty]." (Suomennos Arno Forsius. Lainaus on Arno Forsiuksen kirjasta Tietämisen riemu ja tuska - Sigfridus Aronus Forsiuksen elämä)

1809 ja 1810. Vuodeksi 1811 Aleksanteri I antoi itse Turun Akatemialle yksinomaisen oikeuden "kustantaa ja julkaista tavallisia almanakkoja suomen ja ruotsin kielellä", ja vuoden 1811 alussa erioikeus muutettiin pysyväksi. Kuten aikaisemmin todettiin, Turun Akatemian nimi muutettiin myöhemmin Keisarilliseksi Aleksanterin Yliopistoksi ja sitten Helsingin yliopistoksi.

Sama almanakkaerioikeus kirjattiin Suomen itsenäistyttyä yliopistolakiin ja -asetukseen.

Helsingin yliopisto ei itse ryhtynyt kalentereita kustantamaan, vaan vuokrasi erioikeuden jollekin kirjapainolle. 1800-luvulla almanakkakirjapainona oli esimerkiksi helsinkiläinen J.C. Frenckell \& C. Vuodesta 1888 sata vuotta eteenpäin almanakkaerioikeus oli Weilin\&Göösin hallussa.
Aluksi almanakkaerioikeus oli lähinnä pelkkä muodollisuus, kun Suomessa oli vain yksi tai kaksi yliopiston julkaisemaa kalenteria. Mutta 1900-luvulla kalenterien määrän räjähdysmäisesti kasvaessa erioikeudella oli todellista taloudellista merkitystä.

Koska erioikeus koski vain suomen- ja ruotsinkielisiä kalentereita, lakia kierrettiin julkaisemalla kalenterit muilla kielillä. Viime vuosikymmeninä tavallisin kiertotie oli julkaista kalenterit englanniksi.

Almanakkatoimiston kalenteriselvityksessä 1990-luvun puolivälissä löytyi yliopiston vapaakappaletoimistosta hupaisia kalentereita, joihin erioikeus ei ulottunut. Esimerkiksi Kuopion yliopiston ylioppilaskunta julkaisi kalenterinsa välillä viroksi tai lätiksi. Luonnonsuojelijoiden siilikalenteri oli puolestaan siilinkielellä eli lähinnä siansaksaa.

Valio yritti kiertää erioikeutta julkaisemalla "kielettömän" kalenterin: ruokaohjeiden alapuolella oli pelkkä numeroruudukko, jossa ei ollut yhtään sanaa. Asiasta kehkeytyi oikeusjuttu, jonka Valio lopulta hävisi. Koska ruokaohjeet olivat suomeksi ja Suomen itsenäisyyspäivä oli merkitty punaisella, katsottiin kalenteri suomenkieliseksi ja Valio joutui maksamaan siitä erioikeusmaksun.

\section{Erioikeuden loppu}

Kun almanakkaerioikeuden taloudellinen merkitys tuli yhä suuremmaksi, asia herätti keskustelua tiedotusvälineissä ja kateutta toisissa kirjapainoissa. Helsingin yliopisto ryhtyikin pitämään erioikeuden vuokraamisesta reiluja tarjouskilpailuja kaikkien kirjapainojen kesken.

Viimeinen tarjouskilpa pidettiin 1980-luvun puolivälissä, ja sen voitti hieman yllättäen Werner Söderström Osakeyhtiö. Weilin\&Göös uskoi viimeiseen asti, ettei Helsingin yliopisto hylkää satavuotiasta yhteistyökumppaniaan, eikä korottanut tarjoustaan tarpeeksi. Weilin\&Göös tunnusti jälkeenpäin tehneensä tässä karkean virheen.

WSOY opetteli parin vuoden ajan kalenterintekoa ja kilpaili asiakkaista Weilin\&Göösin kanssa, joka painatti kalenteriarkkinsa WSOY:llä ja hoiti itse muut kalenterisivut. Asiakkaat olivat tyytyväisiä, kun kilpailun takia kalenterien hinnat laskivat, mutta kumpikin kalenteriyhtiö näki kilpailun syövän taloudellista tulostaan.

Neuvottelujen jälkeen WSOY ja Weilin\&Göös päättivät haudata sotakirveet, ja ne perustivat yhteisen kalenteriyhtiön, Ajasto Osakeyhtiön. 
Näin Suomessa oli jälleen yksi ainoa kalenterikirjapaino, ja kalenterien hinnat nousivat entiselle korkealle tasolleen.

Almanakkaerioikeuden loppu oli kuitenkin jo lähellä. Suomi teki päätöksen Euroopan unioniin liittymisestä, ja Suomen lainsäädäntö piti tehdä EU:n säännösten mukaiseksi. Lakimiehet tutkivat almanakkaerioikeutta koskevia säännöksiä ja totesivat, että ne rikkovat EU:n kilpailulakeja vastaan. Almanakkaerioikeudesta piti siksi luopua.

Vuoden 1994 lopulla säädettiin laki, jonka mukaan yliopistolla ei vuoden 1995 alusta lähtien ole enää yksinoikeutta kalenterien julkaisemiseen. Näin päättyi Suomessa vuodesta 1749 asti vallinnut almanakkaprivilegio.

Helsingin yliopisto oli ansainnut erioikeuden viimeisinä vuosina noin yhdeksän miljoonaa markkaa vuosittain erioikeusmaksuina. Valtio lupasi korvata saman summan yliopistolle budjetissa kolmena seuraavana vuonna täysimääräisenä ja sen jälkeen parin vuoden ajan osittain, kunnes korvaus poistuu kokonaan.

Yliopisto järjesti tarjouskilpailut kahden oman kalenterinsa, perintei-

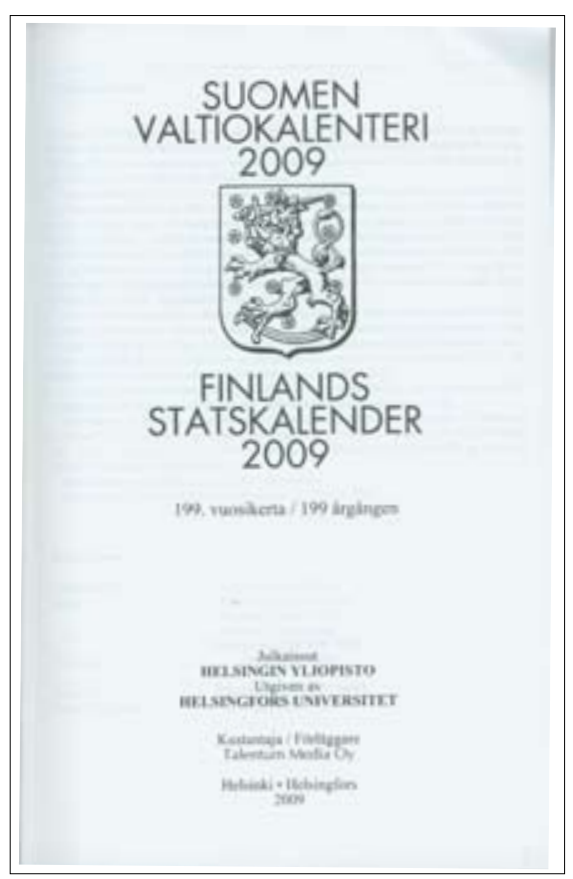

Valtiokalenteria on julkaistu jo Ruotsin vallan aikoina ja suomeksikin vuodesta 1869 alkaen. sen Yliopiston almanakan ja Valtiokalenterin kustantamisesta ja sai niistä solmituksi kohtuulliset sopimukset. Yliopiston almanakkaa julkaisee Ajasto Oy ja Valtiokalenteria Talentum Media Oy.

Lisäksi yliopisto perusti erityisen almanakkatoimiston hoitamaan muuta kalenteriliiketoimintaa ja auttamaan markkinoille tulevia uusia kalenterinvalmistajia.

\section{Kiistelyä nimipäivistä}

Almanakkatoimiston tärkein tulonlähde on Helsingin yliopiston laatima nimipäiväluettelo. Suomalaiset haluavat nähdä nimipäivät kaikissa kalentereissaan.

Moni on ihmetellyt sitä, että nimipäivien julkaiseminen on maksullista. Nimipäivät muodostavat kuitenkin luettelon, jonka laatimisessa on käytetty paljon työtä ja asiantuntemusta. Tällaisella luettelolla on Suomen tekijänoikeuslain mukaan nykyään viidentoista (aikaisemmin kymmenen) vuoden suoja-aika, jolloin sen voi julkaista vain tekijän (Helsingin yliopiston) luvalla.

Nimipäivien tekijänoikeutta on jouduttu pohtimaan oikeutta myöten. 7 päivää -lehti julkaisi vuoden 1995 alkupäivinä, heti erioikeuden poistuttua, kalenterin, jossa olivat mukana nimipäivät. Helsingin yliopisto lähetti lehdelle laskun nimipäivien käytöstä, mutta 7 päivää ei suostunut maksamaan laskua. Siksi yliopisto haastoi lehden julkaisijan oikeuteen.

Ennen kuin oikeus antoi päätöksensä, nimipäivien tekijänoikeutta pohdittiin opetusministeriön tekijänoikeusneuvostossa, jonka tehtävänä on antaa lausuntoja ja suosituksia tekijänoikeusasioissa.

Neuvosto käsitteli nimipäiväasiaa kahteenkin otteeseen ja oli molemmilla kerroilla sitä mieltä, että nimipäiväluettelo on tekijänoikeuslain suojaama ja sen käytöstä on maksettava kohtuullinen korvaus.

Helsingin käräjäoikeus teki päätöksensä syksyllä 1996 ja tuli samaan tulokseen. Se tuomitsi 7 päivää -lehden maksamaan yliopiston laskun ja oikeudenkäyntikulut.

7 päivää -lehti valitti päätöksestä hovioikeuteen, mutta hovioikeuden ratkaisu oli edelleen sama. Talvella 1998 lehti lopulta maksoi vuoden 1995 alussa lähetetyn laskun. Lehti valitti vielä korkeimpaankin oikeuteen, mutta korkein oikeus vahvisti alempien tuomioistuinten päätöksen lopullisesti keväällä 2000 . 
Kun nimipäiväluetteloa uusitaan, alkaa viidentoista vuoden suoja-aika aina uusitun luettelon julkaisuhetkestä. Vuonna 2010 voimaan tullut luettelo julkistettiin lokakuussa 2008, ja se on siten suojattu vuoden 2023 lokakuuhun asti.

\section{Kalenterimarkkinat erioikeuden jälkeen}

Erioikeuden päättymisestä on nyt kulunut toistakymmentä vuotta, ja moni asia Suomen kalenterimarkkinoilla on muuttunut.

Useiden kalenterityyppien hinnat ovat laskeneet ja ilmaiskalenterien määrät voimakkaasti nousseet. Nyt kun kalenterien teko on paljon halvempaa kuin erioikeusaikaan, jaetaan suuripainoksisia kalentereita esimerkiksi lehtien välissä ja tilaajalahjoina.

Myös uusi tekniikka on tunkenut kalenterimarkkinoille, ja valokuvaliikkeistä saa nykyään omilla kuvilla varustetun kalenterin kohtuuhintaan.

Kalenterien kirjo on kasvanut sekä parempaan että halvempaan suuntaan. Laatuhaitarin yläpäähän on tullut komeita, usein ulkomailla painettuja kalentereita, ja toisaalta pienetkin ryhmät voivat nyt tehdä aikaisempaa vapaammin oman kalenterin, jossa ei käytetä suuria rahoja eikä aina kovin tiukkoja laatuvaatimuksia.

Ajasto, nykyiseltä nimeltään Ajasto Paperproducts Oy, on edelleen suurin suomalainen kalenterinjulkaisija, mutta sen markkinaosuus on pudonnut vuosi vuodelta. Sen huomattavimpia kilpailijoita ovat kansainvälinen Time/System, suomalainen CC kalenteripalvelu, kalenterivalikoimaansa lisännyt Otava/Otavamedia, lehtitalo Sanoma Magazines, ruotsalainen Burde Förlag ja kansainvälinen kuvakalenterien julkaisija Scandecor. Varsinkin kuvakalenterien kohdalla myös hyvin moni suomalainen kirjapaino on päässyt jakamaan entisen erioikeuden jättämää etua.

\section{Yliopiston almanakka ja sen kilpailijat}

Kaiken kalenteritulvan keskellä on suosituimman myytävänä olevan kalenterin titteli pysynyt edelleen perinteisellä keltakantisella kansanalmanakalla, joka sai 1990-luvulla nimekseen Yliopiston almanakka.

1970-luku merkitsi kansanalmanakan kohdalla melkoista mullistus-
Suomen Posti julkaisi vuoden 2005 alussa oman postimerkin suomenkielisen almanakan 300-vuotisen taipaleen kunniaksi.

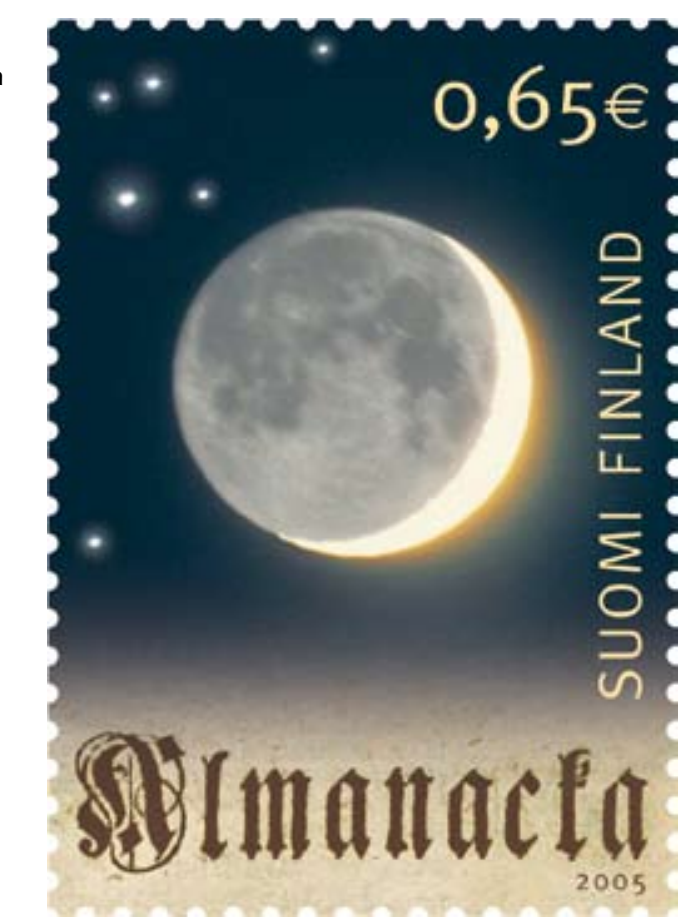

ta. Almanakka siirtyi tietokoneaikaan; almanakan neliömäinen muoto muutettiin; erilliset Oulun ja Helsingin almanakat yhdistettiin; ja almanakan tähtitieteellisiä tietoja lisättiin moninkertaisesti.

Almanakan tiedot laskettiin menneinä vuosisatoina ja vuosikymmeninä vaivalloisesti käsin. Vielä 1970-luvun alussa almanakan vuotuisten tietojen laskeminen vaati parin kuukauden työn. 1950- ja 1960-luvun "allakantekijä", professori Victor Ölander, arvioi käyttäneensä tehtävään vuodessa noin 250 työtuntia. Ainoana apuna almanakan tekemisessä Ölanderilla oli pieni laskukone, jolla hän laski käsin kaikki tarvittavat nousu- ja laskuajat.

Victor Ölanderin määräsi Helsingin yliopisto 1949 toimimaan almanakan laskijana. Ölander oli aluksi ollut toimessa yliopiston observatoriossa, josta hän siirtyi Geodeettisen laitoksen palvelukseen. Hän siirtyi eläkkeelle 1960-luvun alussa, mutta jatkoi edelleen almanakkatyötään.

Tietokoneet olivat 1970-luvulle tultaessa kuitenkin jo niin yleistyneet, että almanakankin laskemisessa oli luonnollista siirtyä niiden käyttöön. 
Viimeinen vanhanmallinen kansanalmanakka (vuodelta 1975).

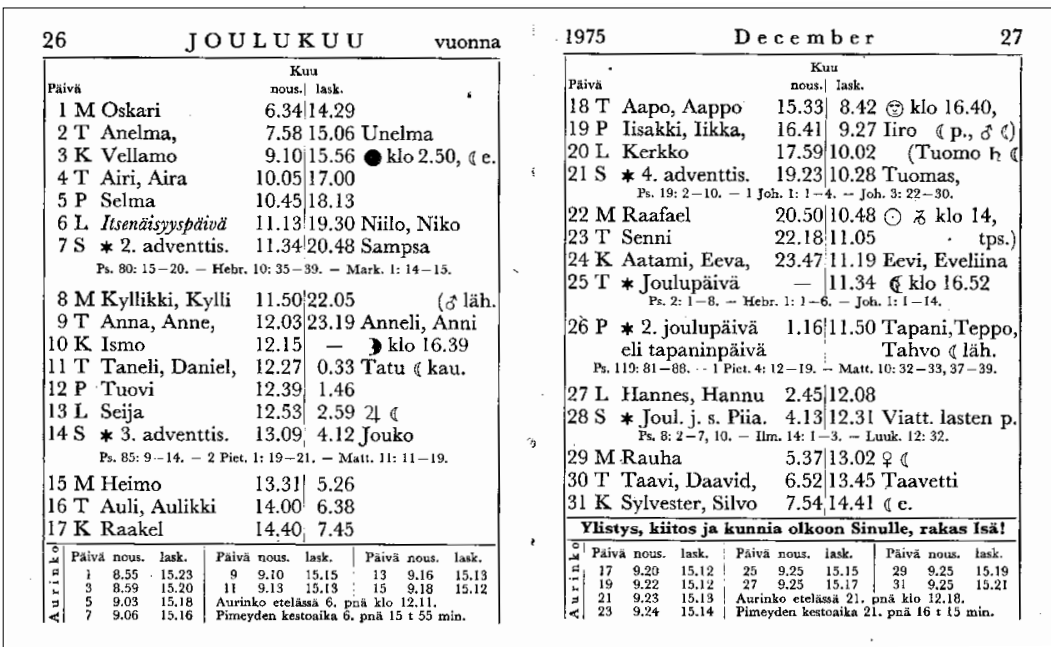

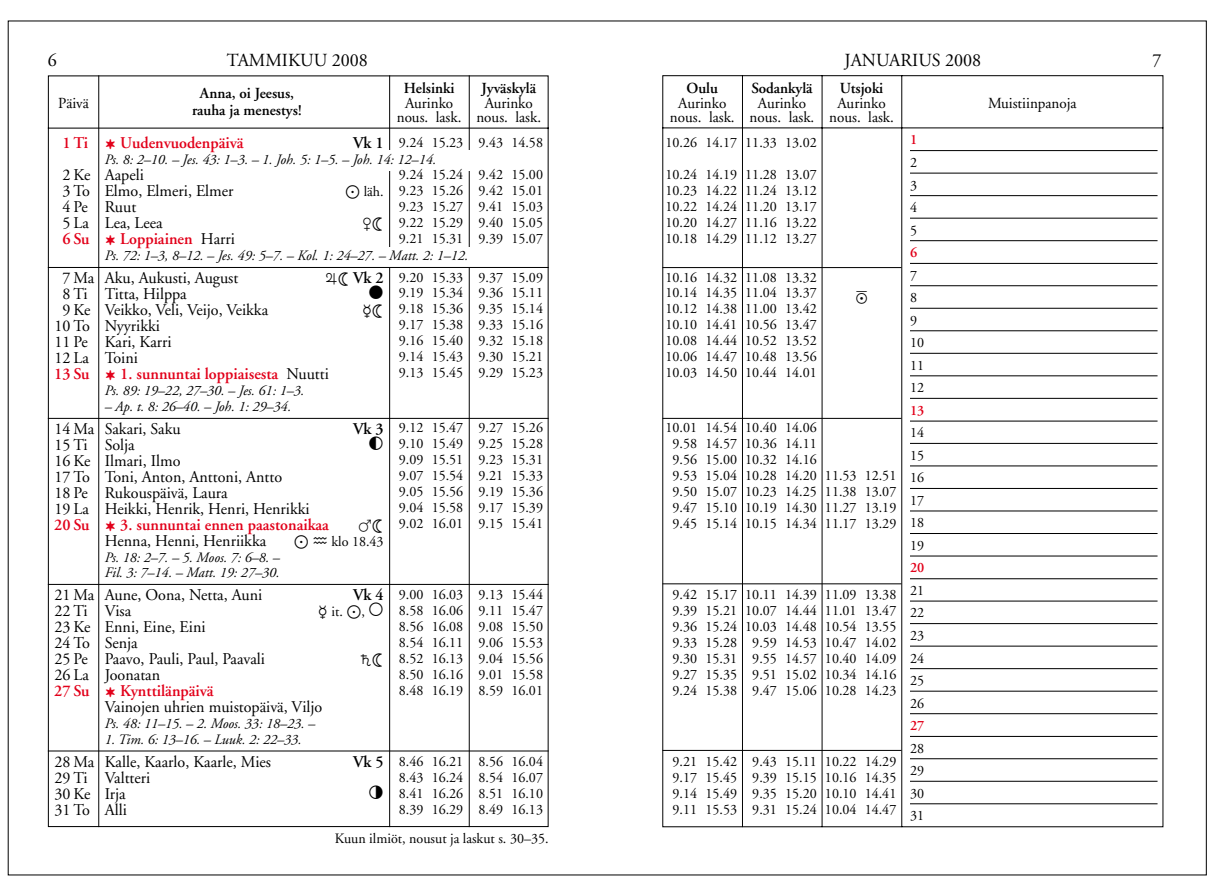

Uudenmallisessa almanakassa on paljon enemmän tietoja kuin vanhassa.
Helsingin yliopistossa professori Jaakko Tuominen antoi oppilaalleen Pentti Törröselle tehtäväksi tarvittavien tietokoneohjelmien laatimisen. Ensimmäiset "tietokonealmanakat" ilmestyivät 1970 monistettuina taulukoina, joita jaettiin kiinnostuneille laitoksille ja järjestöille. Näissä koemonisteissa oli tietoja monta vertaa enemmän kuin virallisissa almanakoissa, ja niistä tuli seuraavina vuosina yhä käytetympiä ja kysytympiä.

Helsingin yliopisto päätti antaa myös virallisen kansanalmanakan laskemisen tietokoneen huoleksi vuoden 1974 alusta. Kahtena ensimmäisenä vuonna almanakka säilyi vielä ulkoisesti perinteisessä asussaan, kunnes vuoden 1976 almanakasta lähtien tietokoneen antamia mahdollisuuksia alettiin käyttää tehokkaasti hyväksi.

Kuten aikaisemmin todettiin, vuodesta 1833 alkaen Suomessa oli julkaistu kaksi erillistä almanakkaa, toinen Helsingin ja toinen Oulun horisontin mukainen. Nyt almanakat yhdistettiin, ja eri paikkakuntien määrä lisättiin viiteen. Uudet allakkapaikkakunnat olivat Jyväskylä, Sodankylä ja Utsjoki yhdessä Helsingin ja Oulun kanssa, ja nämä viisi kattavat Suomen tasaisin välein etelästä pohjoiseen.

Auringon tietojen ohella almanakkaan otettiin entistä runsaammin tietoja kuusta, hämärästä ja pimeydestä, planeetoista ja muista ennustettavista asioista. Almanakan pieni neliömäinen muoto ei enää pystynyt pitämään tätä tietomäärää sisällään, vaan muiden pohjoismaiden esimerkin mukaan kansanalmanakka venähti pari senttiä lisää korkeutta.

Uudistunut kansanalmanakka otettiin hyvin vastaan, ja almanakan vähitellen laskenut myynti kasvoi jonkin aikaa. Parhaimmillaan kansanalmanakkaa myytiin jopa 800000 kappaletta vuodessa, ja sitä julkaistiin useana eri versiona: halpana paperikantisena, tukevampana kartonkikantisena (jossa oli valmis reikä kulmassa, niin että almanakan saattoi ripustaa mökin ovenpieleen helposti saataville), suurikokoisena A4-versiona heikkonäköisemmille, esimerkiksi vanhuksille, ja kolmena ruotsinkielisenä mallina.

Viime aikoina Yliopiston almanakan painosmäärä on tasaisesti laskenut ja oli 2010-luvun alussa enää sadantuhannen kappaleen luokkaa. Syynä laskuun on maaseutuväestön väheneminen, mutta myös toisten tuotteitten kilpailu.

Vielä 1970-luvulla Yliopiston almanakka oli ainoa kansanalmanakka. Sitten Weilin+Göös perusti 1980-luvulla sinikantisen Suomen almanakan, joka sisälsi mm. tilastotietoja Suomesta. Sinikantinen Suomen 


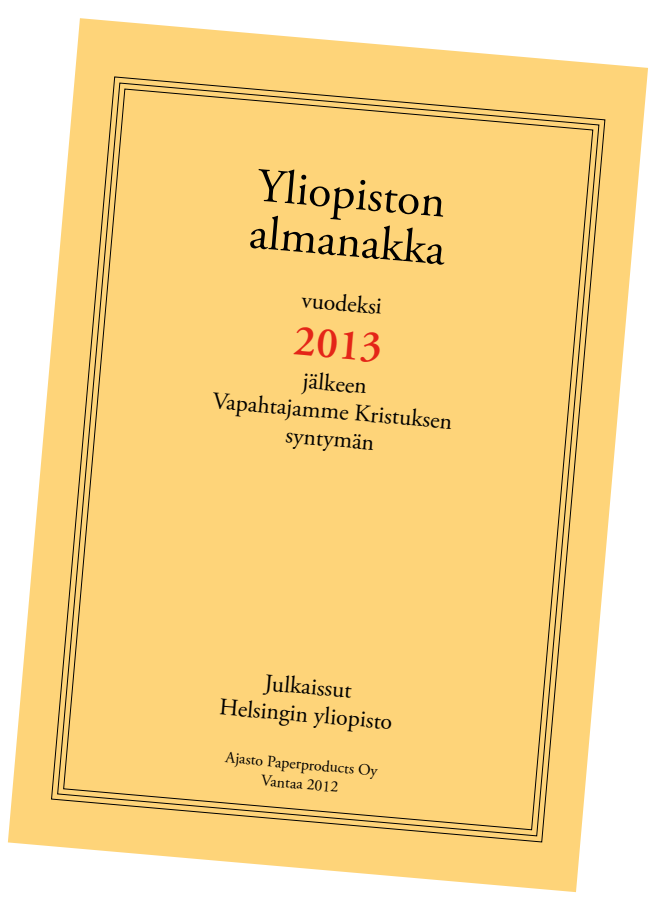

Yliopiston almanakka on vähittäiskaupoissa edelleen ylivoimaisesti myydyin vuosittainen suomalaiskalenteri, vaikka se on saanut rinnalleen muitakin suurilevikkisiä "kansanalmanakkoja".

almanakka ilmestyy edelleen Ajaston kustantamana.

Vuonna 1997 alkoi ilmestyä Otavan Suomen kansan kalenteri, jonka sisältönä on $\mathrm{mm}$. vanhan kansan perinnetietoa ja reilu ripaus astrologiaa.

Burde ei halunnut olla pekkaa pahempi, ja sen Tasavallan almanakka on ilmestynyt vuodesta 1998 alkaen. Sisältö muistuttaa osittain Yliopiston almanakkaa, osittain Ajaston Suomen almanakkaa. Uusin "kansanallakka" on Time/Systemin Kansalaisalmanakka, jota on viime vuosina jaettu osuuspankkien asiakaslahjana.

Valitut Palat perusti 1999 oman Kodin vuosikalenterin. Se on oikea de luxe -kansanalmanakka, johon on koottu houkutteleva sekoitus kalenteritietoutta, sätietoja, kansanperinnettä, astrologiaa ja hyötytietoa.

Millainen on kalenterien tulevaisuus? Sähköiset almanakat ja kalenterit tekevät tuloaan, mutta niiden vaikutus paperikalenterien kokonaismarkkinoihin on ollut vielä vähäinen. Varsinkin nuoriso näyttää kuitenkin
Sähköinen almanakka tarjoaa uudenlaisia mahdollisuuksia. Kuvassa ruotsalaisen AppSoftian tekemä kalenteri älypuhelimiin. Kalenterissa on myös suomalaiset nimipäivät. (Kuva Stefan Granqvist)

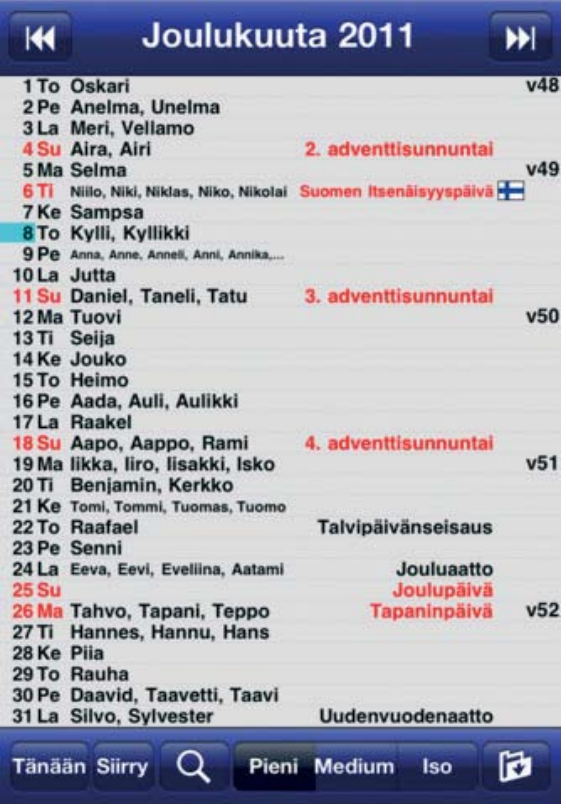

jo käyttävän älypuhelintaan enemmän kuin perinteistä taskukalenteria. On selvää, että osa muistiinpanokalentereista korvautuu vähitellen sähköisillä ohjelmilla.

Sen sijaan kuva- ja seinäkalenterit pitävät puoliaan varmasti vielä pitkän aikaa. Niiden määrä 2000-luvun alussa oli paremminkin nousussa kuin laskussa, kun Suomessa jaettiin ennätysmäärät ilmaisia kalentereita. Viime vuosien lama pudotti kuitenkin myös seinäkalenterien määriä. Paperikalenterien huippuvuodeksi saattoi jäädä 2007, jolloin maassamme myytiin tai jaettiin noin 17,5 miljoonaa kalenterikappaletta, keskimäärin kolme-neljä kalenteria jokaista suomalaista kohti. 


\section{LIITTEET}

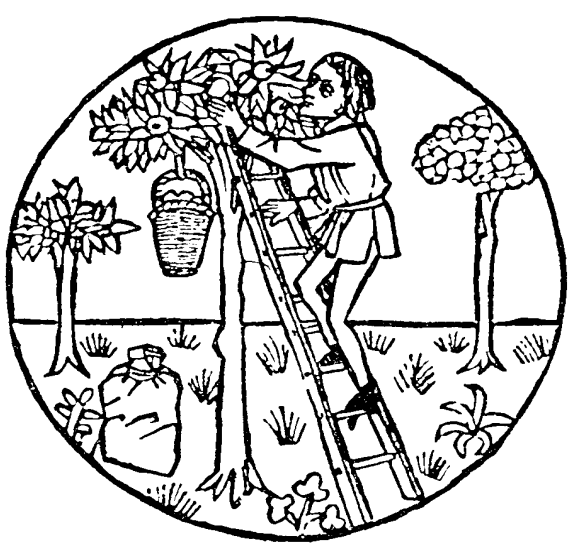

Lokakuun askareita Johannes von Gmundenin kalenterissa: Poimitaan hedelmiä. 


\section{Liite: Tärkeimpiä vuosilukuja ajanlaskun ja kalenterien kehityksessä}

\section{eKr}

4713 nollakohta juliaanisten päivämäärien laskemisessa

3761 juutalaisen kalenterin ensimmäinen vuosi alkoi

46 Julius Caesar sääti juliaanisen kalenterin

jKr

1 länsimaisen kalenterin ensimmäinen vuosi alkoi

532 Dionysius Exiguus käytti ensimmäisen kerran vuosilukuja Jeesuksen syntymästä laskettuna

622 islamilaisen kalenterin ensimmäinen vuosi alkoi

1270 -luvulla rakennettiin ensimmäiset tornikellot

1448 ilmestyi Saksassa ensimmäinen tunnettu almanakka Gutenbergin painamana

1488 Missale Aboense -kirjassa oli suomalaisiin oloihin sovellettu pyhimyskalenter

1544 Agricola julkaisi rukouskirjassaan kalendaarion, jossa oli myös auringon nousu- ja laskuajat

1559 Ruotsi-Suomessa siirrettiin vuoden alku nykyiselle paikalleen

1582 katolisen kirkon paavi määräsi, että ajanlaskussa ruvetaan käyttämään gregoriaanista kalenteria

1608 ensimmäinen suomalainen (ruotsinkielinen) almanakka ilmestyi Forsiuksen toimittamana

1660 suomalainen almanakka alkoi ilmestyä säännöllisesti

1705 ilmestyi ensimmäinen suomenkielinen almanakka Tammelinin toimittamana

1749 Ruotsin Tiedeakatemia sai yksinoikeuden almanakkojen julkaisemiseen

1750 Suomen almanakka alkoi säännöllisesti ilmoittaa auringon ja kuun nousu- ja laskuajat

1753 Ruotsi-Suomen almanakka siirtyi juliaanisesta kalenterista ns. parannettuun kalenteriin (joka pääsiäissääntöä lukuunottamatta yhtyi gregoriaaniseen kalenteriin)

1759 John Harrisonin kronometri osoittautui kyllin tarkaksi pituusasteen määräämiseksi merellä

1772 joukko kiinteällä päivällä olleita pyhiä (mm. mikkelinpäivä) siirrettiin Ruotsi-Suomessa viikonloppuun
Ranskan vallankumouskalenterin alkuhetki

almanakkaerioikeus siirtyi Turun Akatemialle; akatemia muutti 1828 Helsinkiin ja sen nimeksi tuli myöhemmin Helsingin yliopisto

Suomen almanakan horisontti siirtyi Turusta Helsinkiin; almanakassa siirryttiin paikallisajasta keskiaurinkoaikaan

Suomessa alettiin julkaista toista almanakkaa Oulun horisontin mukaan

Suomi siirtyi täydelliseen gregoriaaniseen kalenteriin

Washingtonissa pidetty kokous jakoi maanpinnan 24 aikavyöhykkeeseen ja vahvisti Greenwichin nollameridiaaniksi

sääennustukset katosivat suomalaisesta almanakasta

Suomi siirtyi Helsingin keskiajasta Itä-Euroopan vyöhykeaikaan Suomen almanakan nimipäiväkalenteri kaikkein suomalaisin

Suomen almanakan kellonajoissa siirryttiin ap.- ja ip.-merkinnöistä nykyiseen 24-tuntiseen järjestelmään

marianpäivä, juhannus ja pyhäinpäivä siirrettiin Suomessa viikonloppuun

ajanmittauksen perustaksi hyväksyttiin (päivän sijaan) vuosi ajanmittauksen perustaksi hyväksyttiin (vuoden sijaan) sekunti, joka määriteltiin atomien värähtelyn avulla

koordinoitu yleisaika UTC otettiin käyttöön

oppiainen, helatorstai ja helluntai siirrettiin meillä lauantaiks maanantai vahvistettiin viikon ensimmäiseksi päiväksi ja viikkonumerot otettiin käyttöön nykyisessä muodossaan

Yliopiston almanakka uudistui kooltaan ja sisällöltään ja erillinen Oulun almanakka lakkasi ilmestymästä

lippuasetus antoi Suomen viralliset liputuspäivät

kesäaika otettiin Suomessa jokavuotiseen käyttöön

loppiainen ja helatorstai palasivat Suomessa entisille paikoilleen ja toinen helluntaipäivä poistui

Helsingin yliopiston almanakkaerioikeus loppui

Suomen evankelis-luterilainen kirkko uusi pyhäpäivien nimet karkauspäivä siirrettiin meillä helmikuun loppuun ja almanakan nimipäiväkalenteria uudistettiin

nimipäiväkalenterin uusin uudistus 


\section{LÄHDETEOKSIA JA KUVALÄHTEITÄ}

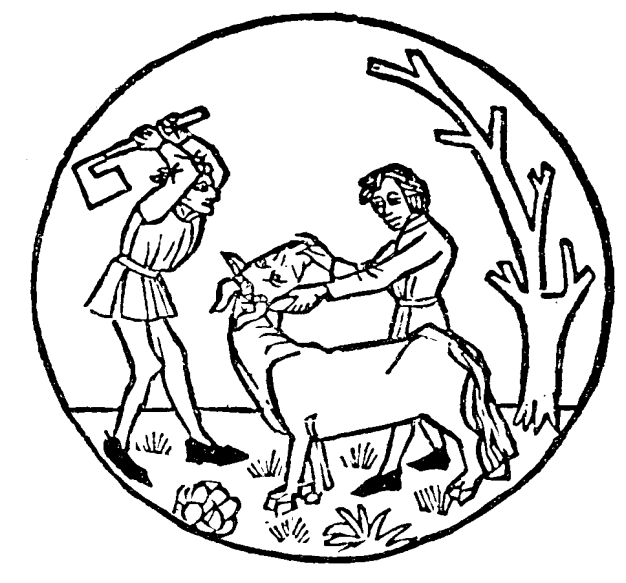

Joulukuun askareita Johannes von Gmundenin kalenterissa: Teurastetaan karjaa.
Alla luetellaan tärkeimpiä lähdeteoksia, joita on käytetty teoksen kirjoittamisessa. Lisäksi apuna on käytetty vuosien 1608-2000 suomalaisia almanakkoja, jotka löytyvät alkuperäisinä ja mikrofilmeillä Helsingin yliopiston kirjastosta, osittain Tukholman kuninkaallisesta kirjastosta, ja skannattuina Yliopiston almanakkatoimiston almanakka-arkistosta internetosoitteesta http://almanakka.helsinki.fi.

\section{Luvut 2: Ajanlaskun aakkosia, ja 3: Ajanmittaus}

Alla årets dagar, Alf Henrikson, Norstedts 1993

Calendars of the World, Margo Westrheim, Oneworld 1994

Explanatory Supplement to the Astronomical Almanac, toim. K. Seidelmann, University Science Books 1992

Suomen almanakan jublakirja, Helsingin yliopisto ja Weilin \& Göös 1957

Time and the Calendars, W.M. O'Neil, Sydney University Press 1978 Whitaker's Almanack 19XX, J. Whitaker \& Sons

Kuvia on saatu mm. teoksista

Atlas der Himmelskunde, Amand Schweiger-Lerchenfeld, A. Hartleben's Verlag 1898

The Cosmographical Glass, S.K. Heninger Jr., The Huntington Library 1977

\section{Luku 4: Luonnon merkkipäiviä vuoden varrella}

Tähtitieteen perusteet, toim. H. Karttunen ym., Ursa 1995 1982 kun planeetat kohtaavat, A. Jännes ja H. Oja, Ursa 1979

Auringonpimennykset, J. Kakkuri ym., Ursa 1989 


\section{Luku 5: Kirkolliset juhlapäivät}

Evankeliumikirja, Suomen kirkon sisälähetysseura 2000

Pyhät ajat, Pentti Lempiäinen, neljäs uudistettu painos, Kirjapaja 1995 Ortodoksisesta kalenterista, Tapani Repo kirjassa Jublakirja, SKS 1979

Kuvia on saatu mm. teoksista

Lexikon christlicher Kunst, toim. Jutta Seibert, Herder 1980

Deutsche Bibeln vor Luther, toim. Walter Eichenberger ja Henning Wendland, Friedrich Wittig Verlag 1977

A Calendar of Saints, toim. Vincent Cronin, Newman Press 1963

\section{Luku 6: Kansalliset ja}

\section{kansainväliset merkkipäivät}

Suomalaisten etunimet, Eero Kiviniemi, Suomalaisen Kirjallisuuden Seura 2007

Vad heter finlanssvenskarna, Marianne Blomqvist, Svenska folk-skolans vänner 2006

Nimipäiväjublat, Minna Saarelma, Kirjapaja 2006

Juhlakirja, suomalaiset merkkipäivät, toim. Urpo Vento, Suomalaisen Kirjallisuuden Seura 1979

Liputusopas, Jari P. Havia ja Pentti J. Mäntynen, Suomalaisuuden liitto 1996

Uusi ajantieto, Sirpa Karjalainen, Teppo Korhonen ja J.U.E. Lehtonen, WSOY 1989

Teemakalenteri, toim. Sami Feiring

Valtiollisen jublakalenterin kehitys Suomessa 1800-luvulta nykypäivään, Antti Pajala 1997 (julkaisematon seminaariesitelmä)

Vuotuinen ajantieto, Kustaa Vilkuna, Otava, kuudes painos 1979

Almanakkatoimiston liputussivut www.liputus.fi ja www.flaggning.fi

Almanakkatoimiston nimipäiväsivut http://almanakka.helsinki.fi/nimipaivat

\section{Luku 7: Suomalaisen almanakan kehitys}

Suomen almanakan jublakirja, Helsingin yliopisto ja Weilin \& Göös 1957
Tietämisen riemu ja tuska, Sigfridus Aronus Forsiuksen elämä n. 15601624, Arno Forsius, Anita Forsius 1996

Almanakkatoimiston almanakka-arkisto http://almanakka.helsinki.fi, josta löytyvät mm. vuosien 1488, 1544 ja 1608-2013 kalenterit

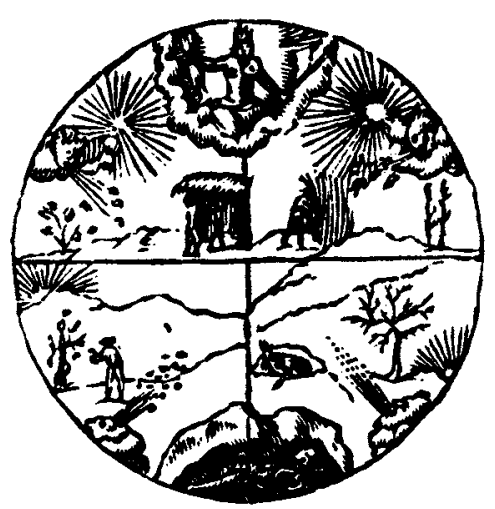

\section{Kuvalähteet}

Osa lähteistä on mainittu myös kuvien yhteydessä.

Helsingin kaupunginmuseo s. 82

Ursan kuva-arkisto 2, 4, 129, 134

Suomen Kellomuseo s. 71, 74 oik., 76

Arno Forsius s. 237

Stefan Granqvist s. 259

Arja Latvala-Oja s. 182, 184, 190, 191, 193, 195, 201

Pekka Parviainen (www.polarimage.fi) s. 23, 70, 133

Heikki Oja s. 6, 85, 111

Wikipedia 65, 78, 144, 160, 164, 177, 200

Muut kuvat Helsingin yliopisto/Yliopiston almanakkatoimisto 


\section{Aakkosellinen hakemisto}

A

adventti 144, 162-164

Agricola, Mikael 186-187, 235

Ahvenanmaan lippu 207

aikavyöhykkeet 64, 81-94

ajantasaus 79-80

Ajasto 253-254, 258

almanakkaerioikeus 248-252

Antinmäki, Riitta 194

Apostolien päivä 159

aprillipäivä 209

Argelander, Friedrich 241

atomikello 95-102

Atosuo, Ismo 205

Augustus 31, 35

auringon jakso 242-243

auringonpimennys 96, 126-132

aurinkoaika 79-81

aurinkokalenteri 24-26

aurinkokello 73

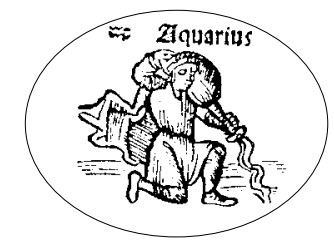

B

babylonialainen kalenteri 53-56

Beda 35-36, 53

Betlehemin tähti 162-163

Blomqvist, Marianne 215

Burde Förlag 254, 258
Caesar, Julius 29-31

Canth, Minna 185

CC kalenteripalvelu 254

Celsius, Andreas 238

Dionysius Exiguus 35, 52-53, 152

\section{E}

egyptiläinen kalenteri 26-28

Einstein, Albert 107

eläinrata 119-121

Eurooppa-päivä 188-189

Euroopan unionin lippu 188

Forsius, Arno 237, 250

Forsius, Sigfridus Aronus 235-236, 249-250

Franklin, Benjamin 103

\section{G}

Galileo Galilei 76-77

Gaussin kaava 152, 154

Greenwichin observatorio 84-85 gregoriaaninen kalenteri 41-47,

$$
\text { 50-51, 62-64, 66-67 }
$$

Gregorius XIII 41-42

Gutenberg 231

H

halloween 201, 204

Harrison, John 78-79
Hasselbom, Nicolaus 239

heilurikello 77

helatorstai 156-157

heliakkinen nousu 28

helluntai 157

Helsingin observatorio 82-84

Helsingin yliopisto 46-47, 52, 82, $106,122,200,214,245,250$ 254

hetki $72-73$

hiekkakello 74

Hillel II 55

Hipparkhos 70, 73, 77

\section{I}

IAT ks. kansainvälinen atomiaika Intian kalenteri 62

islamilainen kalenteri 22, 56-58 isovanhempien päivä 203

isänpäivä 198

itsenäisyyspäivä 174, 199

Jeesuksen syntymä 35-36, 54 Johannes Kastaja 158-159 joulu 164-165

juhannus 158-159, 191

juliaaninen kalenteri 31

juliaaninen päivämäärä 21, 65-66 juutalainen kalenteri 22, 54-57

\section{K}

kaamos 121-124

kaatuneitten muistopäivä 190

Kalevalan päivä 184

kansainvälinen atomiaika 100-102

Kansalaisalmanakka 258
Karjalainen, Sirpa 52, 193 karkauskuukausi 26, 29, 30, 54,

61

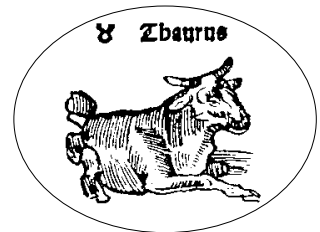

karkauspäivä 29, 35, 44-46, 52-57

karkaussekunti 100-102

karkausviikko 67

karkausvuosi 31, 43-44, 55, 66-67

Keisarillinen Aleksanterin Yliopisto

ks. Helsingin yliopisto

kello 73-109

keskiaika ks. keskiaurinkoaika

keskiaurinkoaika 79-81

keskiyön aurinko 121-124

kesäaika 102-107

kesäpäivänseisaus 30, 114-117 kevätpäiväntasaus 30, 42, 67, 73,

$114-117,152,154-155$

kiinalainen kalenteri 22, 58-62, 64

kiirastorstai 151

kirkastussunnuntai 159-160

Kivi, Aleksis 194-195

Kodin vuosikalenteri 258

Kiviniemi, Eero 215

kolminaisuudenpäivä 157

Konstantinus 38

koordinoitu yleisaika 100-102

Kopernikus 78

kronometri nro 478

kultainen luku 242

Kultima, Johannes 39

Kustaa Aadolfin päivä 197 
kuu-aurinkokalenteri 26

kuuhulluus 136-137

kuukalenteri 24-25

kuukauden päivien numerointi 33-34

kuukausi 22-23, 66

kuukausien nimet 31-33

kuun sirppi 23, 58

kuun vaiheet 22-24, 34, 38-39, 134-137

kuunpimennys 132-133

kvartti 78

kynttilänpäivä 146-147

\section{$\mathbf{L}$}

Lajunen, Lauri 182

laskiainen 147-149

lastenpäivä 198-199

Leino, Eino 192-193

leonidit 140-141

liipotin 76

liputuspäivät 204-208

loppiainen 146

Lönnrot, Elias 184, 186

\section{$\mathbf{M}$}

maapallonaika 108

Mannerheim, marsalkka 190-191 marianpäivä (Marian ilmestyspäi-

vä) $143,148-151$

meteori ks. tähdenlento

Metonin jakso 54

mikkelinpäivä 160

minuutti 77-78

Muhammed 59

musta aukko 109

myrskynmerkit 138-139 naistenpäivä 185

nimipäivät 212-229, 232, 253-254

nollameridiaani 84-85

normaaliaika 106

Numa Pompilius 28

Nykänen, Risto O. 88

\section{$\mathbf{O}$}

ortodoksinen kalenteri 174-177

Otava 254, 258

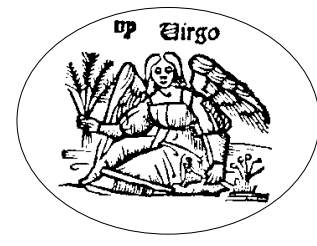

$\mathbf{P}$

paasto $56,59,147-148,175$

paikallisaika 82-83, 87

palmusunnuntai 151

Palviainen, Asko 121

parannettu kalenteri 44-46

perheen sunnuntai 160

perjantai 13. päivä 49-51

pitkäperjantai 151, 153

prekessio 119, 121

Ptolemaios 84

puolustusvoimain lippujuhla 191

pyhimyskalenteri 168-173, 212

pyhäinpäivä 161

pyhäpäivien siirrot 165-167

pyrstötähti 138-139

päivä ks. vuorokausi

päivämääräraja 87, 94-95

pääsiäinen 42, 44-46, 56, 67, 150-

155

\section{$\mathbf{R}$}

Ranskan vallankumouksen kalenteri 22, 63-64

riimusauva 38

Romulus 28

romanien kansallispäivä 186

roomalainen veroluku 242

roomalaisten kalenteri 28-36

rukouspäivät 172-174

rukoussunnuntai 156

Runeberg, Johan Ludvig 181

ruotsalaisuuden päivä 198

\section{S}

saamelaisten ajanlasku 40 saamelaisten kansallispäivä 182 saamelaisten liputuspäivät 181, 207

Saarelma-Paukkala, Minna 215

Sammallahti, Pekka 215

Scaliger, Justus 65

Scandecor 254

seksageesima 147-148

sekunti 77-78, 99-103

septuageesima 147-148

Sibeliuksen päivä 200

Snellman, Hanna 186

Snellman, Johan Vilhelm 189

Sosigenes 29

spiraalijousi 76

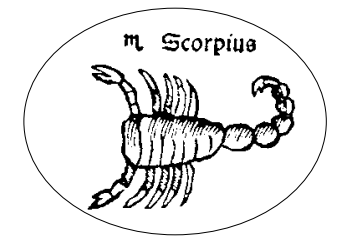

suhteellisuusteoria 107-109

sunnuntaikirjain 243-244

suomalaisten ajanlasku 38-40

Suomen almanakka 258

Suomen kansan kalenteri 258

Suomen lippu 204

suwi-päiwä 209

syyspäiväntasaus $30,56,63,73$,

$$
\text { 114-117 }
$$

sähköinen kalenteri 259

sääennustukset 232, 239-242

talvipäivänseisaus 31, 114-118

Tammelin, Laurentius 237-238

tapaninpäivä 164

Tasavallan almanakka 258

tertti 78

tiimalasi 74

Time/System 254, 258

Topelius, Zacharias 111

tulikello 74

tulipallo 139

tunti 70-73, 77

Tuominen, Jaakko 257

tuomiosunnuntai 161

Turun Akatemia 236-237, 241, 250

Turun messukirja 234-235

tähdenlento 139-141

tähtisade 139-14

Törrönen, Pentti 257

$\mathbf{U}$

unikeonpäivä 193

UTC ks. koordinoitu yleisaika uusivuosi 143-145, 180 


\section{V}

vainojen uhrien muistopäivä 181 vallankumouskalenterit 63-65

Vallentunan kalenteri 33

Valtiokalenteri 84, 245, 252-253 vappu 174, 187-188

Venäjän ortodoksinen kalenteri 21

Venäjän vallankumouksen kalenteri 64-65

vesikello 73-74

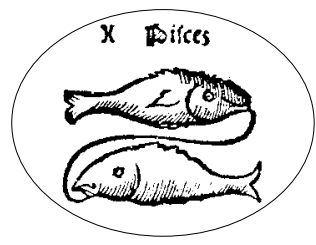

veteraanipäivä 186

viattomien lasten päivä 164-165

viikko 36-39, 46-50, 58, 63-65

viikkonumerot 47-48

viikonloppu 49

viikonpäivien nimet 36-38, 48-50
Vilkuna, Kustaa 39-40, 208, 215

vuoden alku 30, 39, 44, 58, 143 144

vuoden pituus 22-24, 28-30, 41, 99, 119

vuodenajat 111-118

vuorokausi 22-23, 69-73, 96-99

vuosituhat 50,52

\section{W}

Willet, William 103

$\mathbf{Y}$

YK:n päivä 195

YK:n teemapäivät 196-197

Yliopiston almanakka 253-258

yrittäjän päivä 194

ystävänpäivä 183

\section{$\ddot{\mathrm{A}}$}

äitienpäivä 189

Ö

Ölander, Victor 255

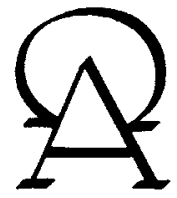

